\title{
Growth and Maintenance in the Plaice (P. platessa, L.) Part II.
}

\author{
By
}

Ben Dawes, A.R.C.S., D.I.C., F.L.S.

With 11 Figures in the Text.

\section{CONTENTS.}

PAGE

I. Results of the Cawsand Experiments of 1930 . . . . . . 879

1. Minimum Requirements and Maintenance $\quad . \quad$. $\quad . \quad$. $\quad .879$

2. Maximum Requirements and Growth . . . . . . . 884

3. Growth and Intermediate Food Supplies . . . . . . . . 891

4. Conclusions drawn from the Experiments, 1930 (Cawsand) . $\quad$. $\quad$. 893

II. Results of the Lympstone Experiments of 1930 . . . . . 896

1. Experiments of January to April . $\quad$. $\quad . \quad$. $\quad . \quad$. $\quad . \quad 896$

2. Minimum Requirements and Maintenance . . . . . . 897

3. Maximum Requirements and Growth ․ . . . . . $\quad$. 899

4. Conclusions drawn from the Experiments of 1930 (Lympstone) . . 902

iII. General Discussion of tue Results of tue Platce Experiments of 1928-1930 . $\quad . \quad . \quad . \quad . \quad . \quad . \quad . \quad . \quad .903$

IV. Acknowledgement . . . . . . . . . . . . . . . . 915

V. TABLES 1-66 . . . . . . . . . . . . . . . .

\section{INTRODUCTION AND METHODS.}

IN a previous paper (Journ. Mar. Biol.Assoc., Vol. XVII, No. 1, Sept., 1930) I described in detail a series of experiments on Growth and Maintenance in the Plaice which were carried out during 1928 and 1929 at Cawsand, near Plymouth, and at Lympstone, near Exmouth. The purpose of the present paper is to present and discuss data collected at the above places during 1930 in continuing the experiments. The conditions under which the last experiments were carried out were identical with those of 1929, i.e. refined with reference to those of 1928. Several additions were made, however, to the series of 1929. Two fish of each sex were supplied with maximum rations while living under the conditions maintained during 1928 and were segregated in a box, which had the original $\frac{1}{2}^{\prime \prime}$ mesh wirenetting windows but which was divided up into compartments. This experiment was arranged in order that we might ascertain the possibility 
of food leakage due to tidal action during the course of the earliest experiments, but it also enables us to compare the results obtained under slightly different conditions of water circulation, which is important in view of the fact that the windows of the modified boxes were of necessity minimal in area.

There is yet another departure from the experiments of 1929. The results of the experiments of 1928 tended to show, if in a rather unsatisfactory manner, that fish taking quantities of food intermediate between maintenance and maximum rations made more efficient use of food for purposes of growth than did maximum-fed fish. Unfortunately, the refinement of the preliminary experiments during 1929 entailed an additional amount of routine work and made it impossible to check these promising results. The question of increased efficiency with intermediatefeeding is a very important one, and it was deemed advisable during 1930 to obtain evidence which would either support or refute the conclusion so tentatively put forward and to impart some finality to our views. Accordingly, two fish of each sex were kept segregated under the refined conditions and in parallel with maximum-fed fish. These fish were supplied with intermediate rations, roughly twice the value of maintenance rations. The number of fish is admittedly small, but it must be emphasised that the inclusion of these four fishes in the experiment distended the routine work to such an extent that it was quite impossible to include more.

Apart from these details, the experiments of 1930 were identical with those of 1929. Feeding operations were performed daily, the food being Mytilus edulis as before, and especial care was taken to avoid the inclusion of food fragments likely to be washed out of the boxes by the tides. Each day, before food rations were presented to the fish, the surplus food from the previous meal was meticulously removed and "weighed back." Weighing and measuring operations were performed fortnightly as before, and the time interval between the last meal of the fortnight and the weighing was maintained as constant as was practicable. Temperature records were kept at Cawsand and Lympstone alike, graphs of weekly maxima and minima being prepared finally from them.

Before passing on to a description of results, it must be mentioned that during the first two months the routine work was carried out by Miss Thursby Pelham of the Ministry of Agriculture and Fisheries Laboratory, Lowestoft, and her assistant, under my supervision and direction. Again, during early September I was on leave and in mid-September resigned my position in order to take up an appointment in London. The experiments were therefore directly carried out by me only during the latter part of June and during July and August. When I left the work, Messrs. G. M. Spooner and J. E. Smith of the Marine Biological Association Laboratory, Plymouth, jointly took charge of the experiments, the data 
of which were sent to me in London. Before proceeding I wish to record my thanks to the above-mentioned people for their contributions to the work. Mr. H. Lees, Tank Superintendent of the Ministry of Agriculture and Fisheries Mussel Tanks, Lympstone, retained his charge of the Lympstone experiments under the direction of Dr. E. S. Russell and Mr. T. Edser, who kindly sent me the data obtained. Thanks are due to Mr. Lees for his share of the work and especially for the observations which were continued throughout the winter of 1929 .

\section{RESULTS OF THE CAWSAND EXPERIMENTS OF 1930.}

\section{Minimum Requirements and Maintenance.}

Data concerning the experiments with male fish supplied with minimum rations are shown in Tables 1-6, these fish being referred to as $\mathrm{C} 1-\mathrm{C} 6$. It will be seen from these tables that the initial sizes of the $\mathrm{C}$ fish form an ascending series from $\mathrm{C} 1$ ( $13.1 \mathrm{~cm}$; $21.5 \mathrm{gm}$.) to $\mathrm{C} 6(23.0 \mathrm{~cm}$. ; $115 \cdot 0 \mathrm{gm}$.), and it will be realised that the size range thus covered by the series is roughly the size range of growth of maximum-fed, fully-growing plaice during the third season of growth. The aim of these experiments is to obtain data which can be applied to an estimation of the gradually increasing maintenance requirements of plaice which are passing through this season of unrestricted growth. The uniformity displayed in the results of earlier experiments of the same kind with numbers of fish of the same size, justifies this attempt to measure the variation in maintenance requirements with single fish of increasing size, particularly as earlier work had not provided really satisfactory results and as there was no possibility of increasing the number of fish included in the experiments.

The smallest fish, C1 (initial length $13.1 \mathrm{~cm}$. ; initial weight $21.5 \mathrm{gm}$.), * was maintained fairly constant in weight over a period of 144 days (final weight, $20 \cdot 8 \mathrm{gm}$.), slight losses during the early part of the experiment being due to a refusal to take food. The total quantity of food taken during 144 days was $66.9 \mathrm{gm}$., or roughly 3 times the mid-body-weight. During the various fortnightly periods, less than $0.40 \mathrm{gm}$. of food per day resulted in slight loss of weight; more than $0.50 \mathrm{gm}$. per day in increase in weight except in one instance (Sept. 19th, Table 1). The maintenance requirements of a $21 \mathrm{gm}$. male plaice thus appear to lie between $0.4 \mathrm{gm}$. and $0.5 \mathrm{gm}$. of food per day, i.e. between 0.019 and 0.024 of the mid-body weight for the periods considered (=the maintenance ratio). For 144 days, an average of $0.46 \mathrm{gm}$. of food per day was required, yielding a maintenance ratio of $0 \cdot 022$.

\footnotetext{
* In the descriptions to follow, the abbreviations init. lth. (for initial length) and init. wt. (for initial weight) will be used.
} 
C2 (init. lth. $15 \cdot 3 \mathrm{~cm}$; init. wt. $31.5 \mathrm{gm}$.) (Table 2) showed. slight periodic fluctuations in weight, but after 176 days had increased its initial weight by only $4.4 \mathrm{gm}$. Slight losses in weight occurred during three periods when the average daily ration was less than 0.47 gm., slight gains during eight periods when it was more than $0.45 \mathrm{gm}$. The maintenance ration would therefore appear to be $0.45-0.47 \mathrm{gm}$. per day, the corresponding ratio $0 \cdot 013-0 \cdot 014$. Over 176 days the average daily ration was. $0 \cdot 49 \mathrm{gm}$., the maintenance ratio $0 \cdot 015$.

C3 (init. lth. $16.9 \mathrm{~cm}$. ; init. wt. $45 \cdot 0 \mathrm{gm}$.) (Table 3) was kept to within $2 \mathrm{gm}$. of its initial weight over a period of 162 days, despite periodic fluctuations. This fish can be taken to illustrate the difficulty entailed in an attempt to maintain the weight of any plaice constant for a succession of fortnightly periods, although it would be easy to find other suitable examples. For the period ending June 23rd the average daily ration was $0.57 \mathrm{gm}$. and the body-weight was maintained constant. Consequently, a similar average daily ration was supplied during the next following period to July 7 th, which resulted, however, in the relatively great weight increase of $1.9 \mathrm{gm}$. During the next period to July $21 \mathrm{st}$ the ration was lowered by $0.03 \mathrm{gm}$. per day and the result was good, the weight increase being only $0 \cdot 1 \mathrm{gm}$. A further slight reduction of the ration (by $0.03 \mathrm{gm}$.) during the period ending August 6th resulted in an enormous loss of $2.5 \mathrm{gm}$. in body-weight, and an increased ration (by $0.02 \mathrm{gm}$.) during the period ending August 21st also resulted in loss of weight (1.2 gm.). Thereafter, much greater daily rations were required to maintain the weight of the fish constant. This succession of incidents is important and has been dealt with at such length because it shows clearly how maintenance requirements seem to fluctuate, a difficulty which must inevi ably be encountered in work of this kind. The difficulty is referred to briefly in my previous paper (p. 119).

During the first 100 days of the experiment, C3 lost weight during fortnightly periods whenever less than $0.53 \mathrm{gm}$. of food was taken on the average per day, and gained weight whenever more than $0.54 \mathrm{gm}$. was taken, so that these quantities mark the limits of the maintenance requirements, the maintenance ratio being $0 \cdot 011-0 \cdot 012$. By comparison with the results for other fish, these values are low and this observation is perhaps not altogether disconnected with the fact that beyond this period and to the end of the experiment, C3 required greatly enlarged daily rations for maintenance. It is suggested that during the early part of the experiment weight was maintained constant on unusually small rations by atypic means (e.g. excessive water imbibition), after which some adjustment was effected causing much greater rations to be necessary. For the whole period of 162 days, the average daily ration was $0.64 \mathrm{gm}$., providing a maintenance ratio of $0 \cdot 015$. 
The results of the experiments with the males $\mathrm{C} 4$, C5, and $\mathrm{C} 6$ are shown in Tables 4, 5, and 6. Taking C4 (init. 1th. $18.9 \mathrm{~cm}$. ; init. wt. $59 \cdot 0 \mathrm{gm}$.) first, and noting for the various fortnightly periods loss or gain in weight following upon varying average daily rations, it is found that the maintenance requirements appear to be $0 \cdot 85-0.86 \mathrm{gm}$. of food per day (maintenance ratio $=0 \cdot 014$ ). During the whole course of the experiment (178 days), an average daily ration of $0.89 \mathrm{gm}$. was taken and at the end of this period the initial weight had been increased by $3.5 \mathrm{gm}$., so that the maintenance ratio of 0.015 , which is indicated, is slightly high. C5 (init. lth. $21.2 \mathrm{~cm}$; init. wt. $86.7 \mathrm{gm}$.) appeared to require daily rations of from $0.87 \mathrm{gm}$. to $0.99 \mathrm{gm}$. for maintenance from one period to another (Table 5), this giving a maintenance ratio of $0 \cdot 010-0 \cdot 011$. For the whole period of 164 days an average daily ration of $0.95 \mathrm{gm}$. was taken and the total loss in weight was $1.3 \mathrm{gm}$., so that for the whole experiment the maintenance ratio was $0 \cdot 011$, which closely follows the figures indicated by study of the fortnightly periods. The largest fish, $\mathrm{C} 6$ (init. lth. $23.0 \mathrm{~cm}$; init. wt. $115.0 \mathrm{gm}$.), seemed to require $1 \cdot 27-1.40 \mathrm{gm}$. of food per day for maintenance (Table 6), which suggests a maintenance ratio of $0 \cdot 011-0 \cdot 012$. During 147 days it took an average daily ration of $1.42 \mathrm{gm}$. and lost a total of $3.9 \mathrm{gm}$. in weight, so that for this period a maintenance ratio of 0.013 is indicated.

The results of these maintenance experiments with male plaice are summarised for the whole course of the experiments in Table 7. It is seen that the average daily ration required for purposes of maintenance by males of from $13.1 \mathrm{~cm}$. to $23.0 \mathrm{~cm}$. and from $21.5 \mathrm{gm}$. to $115.0 \mathrm{gm}$. gradually increased from 0.46 to $1.42 \mathrm{gm}$., neglecting slight losses in bodyweight. The corresponding maintenance ratios gradually decreased from 0.022 to 0.012 . The difference between these quantities and values represents the difference between the maintenance requirements of different male plaice of various sizes, but by analogy it can be interpreted as representing the difference between the maintenance requirements of a single male plaice at various times during its third season of unrestricted growth, since the limiting sizes are approximately those which mark the two extremes of this season, having been chosen to serve this purpose. In Figure 1 the decrease in value of the maintenance ratio with increase in size of fish, and therefore by analogy also with increasing age, is shown graphically.

The female plaice used in maintenance experiments, like the corresponding males, were arranged so as to form a series having a total size range comparable with that passed through by a freely-growing female plaice during its third season. The results of these experiments are shown in Tables 8-13, the fish being referred to as A5, A6 (a and b), A2, A4, $\mathrm{A} 3$, and $\mathrm{A} 1$, and being taken in this order, which is that of increasing size. 
In the descriptions to follow the maintenance requirements suggested by the study of fortnightly data will be found, as in the case of males, by noting the periods when loss or gain in weight occurred on average daily rations below or above a certain value. This will render unnecessary much of what would otherwise prove to be tedious and almost endless repetition.

The smallest female A5 (init. lth. $12 \cdot 2 \mathrm{~cm}$; init. wt. $17 \cdot 3 \mathrm{gm}$ ) appeared able to maintain itself on average daily rations of $0 \cdot 39-0 \cdot 47 \mathrm{gm}$. for six consecutive fortnightly periods (July 7th-Oct. 6th; Table 8), the

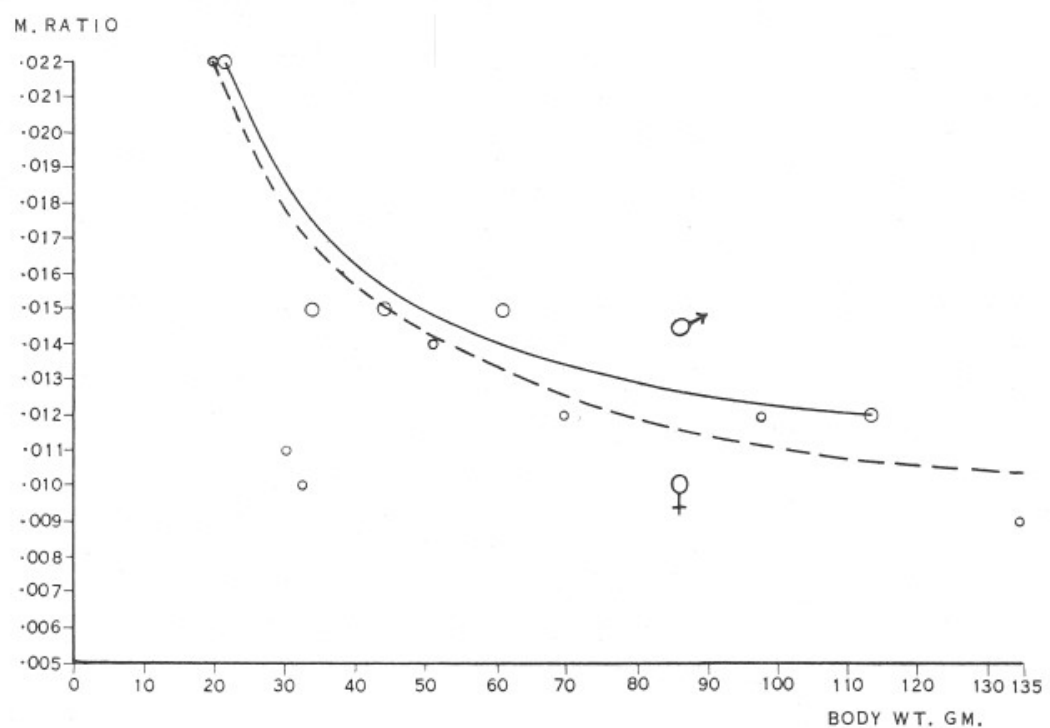

FIG. 1.--Graphs showing, for male and female plaice between 2 and 3 years old, the relationship between the maintenance ratio and the body-weight. Based upon the results of the Cawsand experiments, 1930.

corresponding maintenance ratio ranging from $0 \cdot 018$ to $0 \cdot 025$. During 143 days, an average daily ration of $0.43 \mathrm{gm}$. enabled the fish to maintain itself and to increase its initial weight by $4.7 \mathrm{gm}$., so that the maintenance ratio of 0.022 which is thus indicated is slightly high. Both the fish referred to as A6 steadily declined to take food in sufficient quantities to satisfy their maintenance requirements, with the result that they consistently and steadily lost weight. The data for these fish are shown in Table 9 but we must decline to make use of them since they would scarcely assist our purpose. A glance at the two points widely separated from the curve on the left of Figure 1, which represent the maintenance ratios for these fish, will convince one that these data are best disregarded. 
The data for A2 (init. lth. $17 \cdot 3 \mathrm{~cm}$. ; init. wt. $49 \cdot 0 \mathrm{gm}$.), which are shown in Table 10, indicate that from one fortnightly period to another between July 7 th and September 5th, this fish was able to maintain itself on daily rations of $0.64 \mathrm{gm} .-0.67 \mathrm{gm}$., the corresponding range in the maintenance ratio being $0 \cdot 012-0 \cdot 013$. During 148 days an average daily ration of $0.69 \mathrm{gm}$. allowed of an increase in weight of $4.0 \mathrm{gm}$., so that the maintenance ratio of 0.014 thus indicated is slightly high. A4 (init. lth. $19.8 \mathrm{~cm}$. ; init wt. $71 \cdot 0 \mathrm{gm}$.) required a daily ration of from $0.83 \mathrm{gm}$. to $0.94 \mathrm{gm}$. for purposes of maintenance (Table 11), showing a maintenance ratio of $0 \cdot 012-0 \cdot 014$. Over a period of 178 days there was a slight loss of weight $(2 \cdot 7 \mathrm{gm}$.) after an average daily ration of $0.87 \mathrm{gm}$. had been taken, this figure indicating a maintenance ratio of $0 \cdot 012$.

A3 and A1 were both initially over $100 \mathrm{gm}$. in weight. The daily ration required for maintenance by A3 (init. lth. $22.0 \mathrm{~cm}$. ; init. wt. $101.5 \mathrm{gm}$.) was 1.21-1.29 gm. from period to period (Table 12), the corresponding ratio being $0 \cdot 012-0 \cdot 013$. During 147 days, an average daily ration of $1.21 \mathrm{gm}$. resulted in $6.3 \mathrm{gm}$. loss in weight, so that the maintenance ratio is slightly greater than 0.012 . A1 (init. lth. $24.5 \mathrm{~cm}$.; init. wt. $132.0 \mathrm{gm}$.) required $1.23 \mathrm{gm} .-1.36 \mathrm{gm}$. of food per day for purposes of maintenance from one period to another, the maintenance ratio being $0 \cdot 009-0 \cdot 010$. During 178 days an average daily ration of $1.24 \mathrm{gm}$. allowed this fish to increase its initial weight by $4.9 \mathrm{gm}$., which indicates that the maintenance ratio was slightly less than $0 \cdot 009$.

Summarised data concerning the females used in these maintenance experiments are shown in Table 14, which is set out parallel with Table 7 for males. It is seen that the average daily ration required over long periods for purposes of maintenance by female plaice ranging in length from $12.2 \mathrm{~cm}$. to $24.5 \mathrm{~cm}$. and in weight from $17.3 \mathrm{gm}$. to $132.0 \mathrm{gm}$., increases from $0.43 \mathrm{gm}$. to $1.24 \mathrm{gm}$., the corresponding maintenance ratio diminishing from 0.022 to $0 \cdot 009$. This then is approximately the order of the changes which would occur in the maintenance requirements of a female plaice during its third season of growth since, as in the case of males, the sizes of these maintained fish were arranged in a series, the size limits of which are also the limits for this season of growth.

Thus for male and female plaice alike, the maintenance ratio at the end of the third season of growth is only approximately one-half its value at the commencement of the season. And this is strikingly shown in another way. The following table shows the multiple of the mid-body-weight taken by male and female plaice during the whole period of experiment indicated in days. 


$\begin{array}{lccccc}\begin{array}{c}\text { Multiple of } \\ \text { Jish }\end{array} & \begin{array}{c}\text { No. of } \\ \text { No. }\end{array} & \begin{array}{c}\text { Bys. } \\ \text { Body-wt. of } \\ \text { Food (gm.). }\end{array} & \begin{array}{c}\text { OFish } \\ \text { No. }\end{array} & \begin{array}{c}\text { No. of } \\ \text { Days. }\end{array} & \begin{array}{c}\text { Multiple of } \\ \text { Body-wt. of } \\ \text { Food (gm.). }\end{array} \\ \text { C1 } & 144 & 3 \cdot 2 & \text { A5 } & 143 & 3 \cdot 2 \\ \text { C2 } & 176 & 2 \cdot 5 & \text { A6 } & - & - \\ \text { C3 } & 162 & 2 \cdot 4 & \text { A2 } & 148 & 2 \cdot 0 \\ \text { C4 } & 178 & 2 \cdot 6 & \text { A4 } & 178 & 2 \cdot 2 \\ \text { C5 } & 164 & 1 \cdot 8 & \text { A3 } & 147 & 1 \cdot 8 \\ \text { C6 } & 147 & 1 \cdot 8 & \text { A1 } & 178 & 1 \cdot 6\end{array}$

The smallest fish is shown at the top of the table, the largest at the bottom, and it is clearly indicated that for the smallest plaice the ratio of food-weight to body-weight is double that for the largest plaice. This is in accordance with the suggestion tentatively put forward in my previous paper, although the method then employed of combining Cawsand and Lympstone data was not altogether legitimate.

\section{Maximum Requirements and Growth.}

The growth experiments were marked out into two sets, the first consisting of six fish of each sex housed in the modified boxes with fine mesh windows, the second of two fish of each sex confined in boxes with $\frac{1}{2}$ " mesh windows similar to those used in the preliminary experiments. All fish were segregated, however, and were tended separately. The fish kept under the refined conditions will be referred to as D ( $\hat{\sigma})$ and $\mathrm{B}($ (o) fish respectively, those kept in boxes with $\frac{1}{2}^{\prime \prime}$ mesh windows as M ( 0 \& $q$ ) fish.

The results of the experiments with $\mathrm{D}$ and $\mathrm{B}$ fish are summarised in Table 15, where it is seen that considerable variation in rate of growth characterised both groups. Amongst males, the greatest total increases in length and weight were shown by D1 (4.2 cm. ; $41.3 \mathrm{gm}$.), the least being shown by $D 6$. The rate of growth was generally very slow as compared with that shown during previous years, D1 and D2 succeeding in doubling their initial weights over long periods (162-178 days), other males failing to achieve this result during periods up to 116 days in extent. The relatively slow rate of growth is best shown by comparison of these results with that for D3 during 1929 which, during 175 days, multiplied its initial weight by $6 \cdot 8$. This feature of rate of growth was shown also by females during 1930, none of which achieved much more than a mere doubling of the initial weight, B6 failing to do this, even over a period of 131 days. For the whole range of the experiments the average daily ration varied, among males from 1.6 to $3.0 \mathrm{gm}$., among females from $1 \cdot 8$ to $3 \cdot 5$ gm., so that appetite was rather smaller than during the previous year, when for corresponding periods it ranged among males from $2 \cdot 2$ to 
$3 \cdot 3 \mathrm{gm}$. and among females from $2 \cdot 3-4 \cdot 1 \mathrm{gm}$., neglecting obviously unhappy fish. Efficiency, i.e. the relation between food taken and growth ensuing, also varied in different fish, but to a slighter degree than during the previous year and it was generally much lower, i.e. the indices were greater. Among males 9.1-11.9 gm. of food was required to produce $1.0 \mathrm{gm}$. increase in body-weight, among females $8.5-12.9 \mathrm{gm}$. From the above it will be seen that at Cawsand the growth performances of 1930 were distinctly inferior to those of 1929.

Data concerning the experiment with D1 are shown in Table 16, where it is seen that the increments of length and weight added from period to period were most irregular, especially the latter, which varied from $-0.3 \mathrm{gm}$. to $10.2 \mathrm{gm}$. per fortnightly period. The average quantity of food taken daily varied similarly during different periods, but only slightly, from $2 \cdot 15 \mathrm{gm}$. to $4 \cdot 08 \mathrm{gm}$. Variation also occurred in respect to efficiency, as measured by the quantity of food required to produce $1.0 \mathrm{gm}$. of fish irrespective of time, and was very strongly marked, as will be seen by inspection of col. 6 of the table. The maximum efficiency shown during the whole course of the experiments is represented by the index $4 \cdot 2$ for the period ending June 9 th.

Similar results were shown by the other male plaice, D2-D6 (Tables 17-21). In the case of D2, growth in weight per period varied from $-0.9 \mathrm{gm}$. to $7.0 \mathrm{gm}$., the average daily ration taken from $1.00 \mathrm{gm}$. to $2.64 \mathrm{gm}$., and efficiency between tremendously wide limits (Table 17). Efficiency was greatest (index $4 \cdot 3$ ) during the period of maximum growth (June 9 th ; $7.0 \mathrm{gm}$.). D3 showed maximum appetite ( $3.20 \mathrm{gm}$. per day), maximum growth $(10 \cdot 6 \mathrm{gm}$.), and maximum efficiency (index $4 \cdot 2$ ) for the whole experiment during the period ending July 21st when the ratio $\mathrm{W} / \mathrm{L}^{3}$ attained its maximum value $(0 \cdot 011)$, (Table 18$)$. D4 shows the maximum increase in weight for any period $(6 \cdot 2 \mathrm{gm}$.) when the appetite was a maximum $(2 \cdot 2 \mathrm{gm}$. per day) during the period ending August 6th, when efficiency was high (index $5 \cdot 7$ ) but not a maximum (period ending June 9th; index 4.4). At the same time $W / \mathrm{L}^{3}$ reached its maximum value of 0.010 (Table 19). D5 and D6 did not show such high degrees of efficiency at any time, the maxima for these fishes being represented by the indices $6 \cdot 5$ and $7 \cdot 1$ (Tables 20 and 21 ).

The results of the experiments with males thus lend support to the conclusion previously put forward that there is no simple relationship between the quantity of food taken and the degree of growth ensuing. They also show that such relatively high efficiency as is indicated by the indices $4 \cdot 2-4 \cdot 4$, which neglect maintenance allowances, may be attained at certain indeterminate times during the growth season. In Figure 2 the results of these experiments are shown graphically as regards growth increments of weight. It will be seen that the slopes of the curves shown 
are much less steep than that of the typical sigmoid curve shown for D3 (1929) in my previous paper (Fig. 5, p. 123).

Data concerning the female B1 are shown in Table 22. Growth in length per period varied from $-0.1 \mathrm{~cm}$. to $0.9 \mathrm{~cm}$., growth in weight from $-5.9 \mathrm{gm}$. to $8.6 \mathrm{gm}$. Growth per period was a maximum during the period ending July 21st, when efficiency was also a maximum (index $4 \cdot 7$ ) and when the ratio $W / \mathrm{L}^{3}$ attained its maximum value of $0 \cdot 011$. When

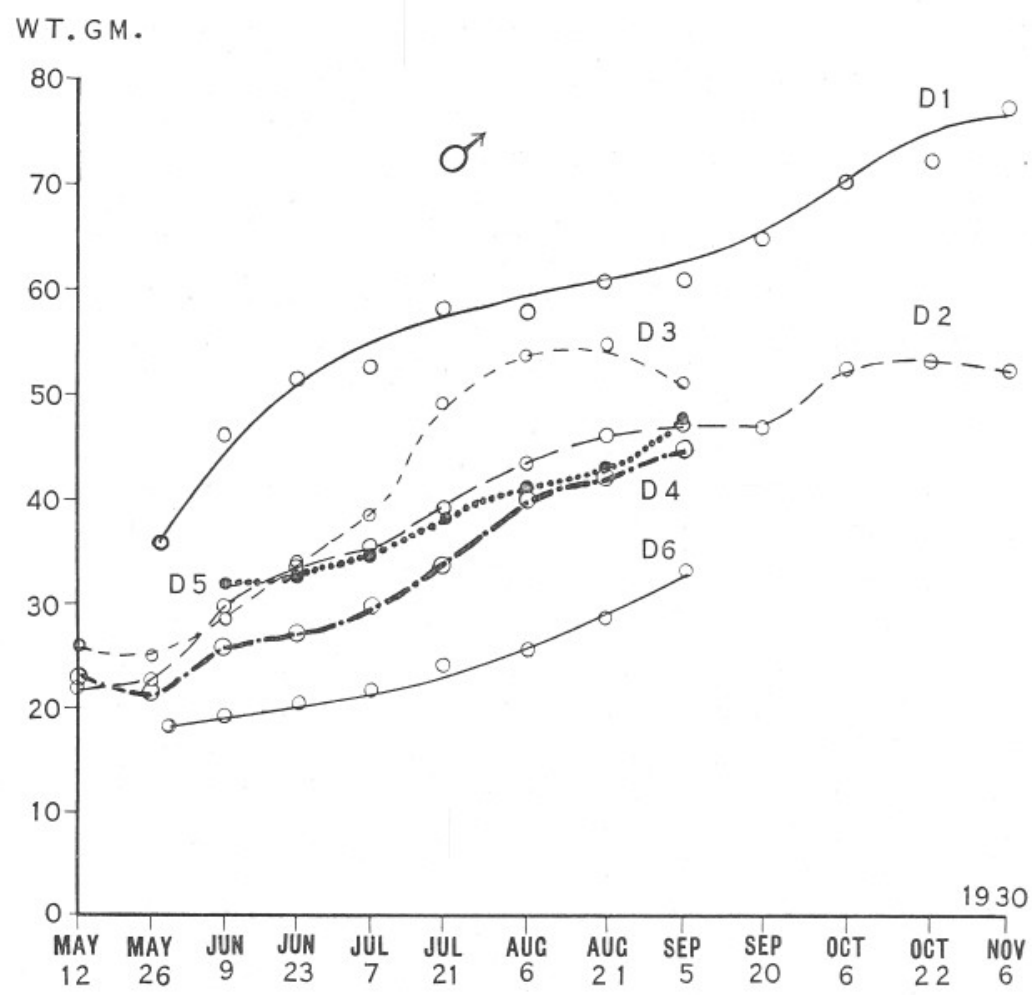

Fic. 2.-Growth curves of weight for the male plaice D1-D6 (Cawsand, 1930).

appetite was greatest (3.48 gm. per day, Aug. 21st), growth and efficiency were both high in degree $(7.5 \mathrm{gm}$. per period; index $7 \cdot 0)$. This fish showed consistently high efficiency from June 17th to August 21st, the index $4 \cdot 7$ occurring during two periods, yet as in the case of the males, considerable variation was shown from time to time.

The remaining females showed similar variations in rate of growth, in efficiency and in appetite from period to period, as will readily be seen if Tables 23-27 be scrutinised. B2 took daily rations ranging from 1.32 gm. to $3.56 \mathrm{gm}$. (neglecting the first week of mere maintenance), increased 
in weight by quantities varying from $0 \cdot 2 \mathrm{gm}$. to $10 \cdot 3 \mathrm{gm}$. per period and showed efficiency indices as widely separated as $4 \cdot 8$ and $30 \cdot 8$ from June to September (Table 23). It is interesting to note that growth, appetite, and efficiency were all maxima during the period ending July 21st. B3 showed maximum growth and efficiency $(5.9 \mathrm{gm}$. ; index $5 \cdot 4)$ during the period ending June 23rd (Table 24). B5 was the most promising fish in the experiments until September 5th when it was lost. From Table 25 it will be seen that the periodic increases in length and weight were consistently great, maxima at $1.0 \mathrm{~cm}$. and $11.0 \mathrm{gm}$. respectively, and that for the whole experiment the efficiency indices lay between the limits $5 \cdot 5$ and $9 \cdot 2$. B4 also showed high efficiency, the index remaining between such narrow limits as $5 \cdot 1-5 \cdot 7$ for three consecutive periods (Table 26). B6 was the least efficient of the Cawsand fish, the maximum being represented by the index $6 \cdot 0$ (Table 27 ).

The results of the experiments with females thus confirm completely the conclusions mentioned above regarding the variation in rate of growth, in appetite and in efficiency from period to period during the growth season. The results show also that the maximum values of these three sets of growth characteristics may or may not coincide in time. The greatest efficiencies shown by the females read as follows : $4 \cdot 7$ (B1), $4 \cdot 8$ (B2), $5 \cdot 1$ (B4), $5 \cdot 4$ (B3), $5 \cdot 5$ (B5), and $6 \cdot 0$ (B6), so that the females are slightly inferior to the males in this respect, the efficiencies of these latter reading $4 \cdot 2$ (D1 and D3), $4 \cdot 3$ (D2), $4 \cdot 4$ (D4), $6 \cdot 5$ (D5), and $7 \cdot 1$ (D6). That such efficiency is not sustained will readily be seen by examination of the tables mentioned above.

The growth curves of weight for the females (Fig. 3) are seen to compare fairly closely with those shown in Fig. 2 for the males. The slopes of the curves are much less steep than those of the curves for B1 and B4 (1929) as shown in Fig. 7 of my previous paper (p. 125).

Turning now to the results of the experiments with M fish (maximumfed fish housed in boxes with $\frac{1}{2}$ " mesh windows), we see in Table 28 , where these results are summarised, that growth has proceeded at much the same rate as in the case of the D and B fishes, excepting M1, which surpassed the rest in performance and succeeded in tripling its initial weight, M2, M3, and M4 failing to achieve this result. The quantities of food taken by this fish greatly exceeded those taken by the D and B fish, but efficiency was not as high. These values, however, are affected by certain incidents to be mentioned below, where it is shown that these results do not have the same degree of accuracy that the other results have.

During the preliminary experiments of 1928, fish supplied with intermediate rations appeared to show a greater efficiency in utilising food for purposes of growth than fully-feeding fish. But intermediate-fed fish invariably take the whole of the ration supplied to them whereas in the 
case of maximum-fed fish there is a distinct possibility of food remaining over from a meal. If during 1928, small quantities of food remained in the boxes containing the latter fish and were washed out of the boxes by ebbing or running tides, then the observed efficiency of the maximumfed fish would be lower than the true efficiency. By comparison, the efficiencies of intermediate-fed fish would appear higher. During the earliest experiments there was no sign of appreciable quantities of food

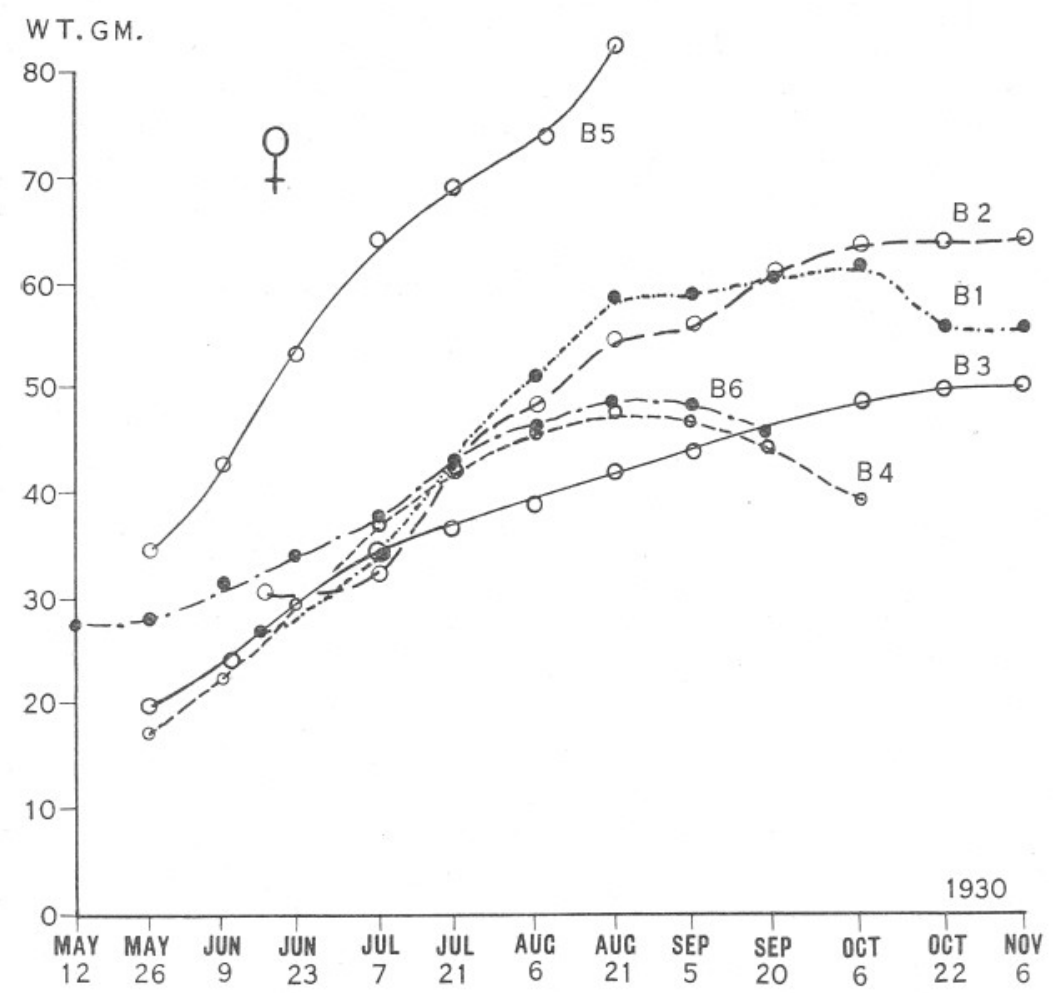

FIG. 3.-Growth curves of weight for the female plaice B1-B6 (Cawsand, 1930).

left over from meals. That fact in itself is strange, since later experiments have shown conclusively that in fish as in other animals, appetite is by no means constant. Thousands of observations made since 1928 have proved this point. Hence it was considered essential to apply a series of tests in order to ascertain the possibility of food having been swept out of the boxes during the earliest experiments. The matter concerns not only food loss but also efficiency of maximum-fed fish, and more importantly of intermediate-fed fish.

To test this possibility of food leakage, Miss Thursby Pelham was asked 
to place into the boxes containing $\mathrm{M}$ fish quantities of food greatly in excess of the normal ration for such fish and to weigh back the quantities remaining on the next day. This was done during the period ending July 7th and by myself during that ending July 21st. More than this, the wire-netting windows were alternately cleared of epifauna and epiflora (as they were regularly during 1928) and allowed to foul (which may happen in one to a few days).

That the data from these tests were conclusive is seen in the single case of M1. During the last seven days of the period ending June 23rd, this fish was taking a ration of less than $6.0 \mathrm{gm}$. per day when the box windows were slightly fouled. During the period ending July 7 th, it was supplied with $15.0 \mathrm{gm}$. of food on each of eight days, when the windows were cleared, and no food was found to remain. In some of the tests when this quantity of food was presented, varying quantities were left over, but the essential point is that on many days, often consecutively, no food remained although much more than a normal ration had been presented and despite the fact that sea conditions were calm. In the tests I applied myself this was similarly the case. Consequently, henceforth I used my own judgment as to the constitution of maximum rations and for the rest of the experiment provided what was considered to be an adequate but not overadequate ration, thus ensuring that loss should be minimal if and when it did occur. This applies only to the M fish of course.

In view of the above-mentioned facts it appears reasonably certain that during 1928 there was some loss of food, yet it must be emphasised that the quantities supplied during this year were not unduly large. Moreover, the fish were active and showed a rapid growth-rate. They took food avidly and it is likely that the losses were small. But loss undoubtedly must have occurred. Hence the suggestion of increased efficiency on the part of intermediate-fed fish is open to doubt, or at least objection. This question, however, has been set quite independently during 1930 and data of greater reliability have been forthcoming. These will be presented when the results of the experiments with M fish have been described.

Data concerning the M males are shown in Tables 29 and 30 and growthcurves of weight are presented in Figure 4 . M1 was the most rapidly growing fish in the experiments, but, like other fish, it showed great variation in rate from one fortnightly period to another. Periods of rapid growthrate, July 7th, 10.3 gm. ; August 21st, 11.0 gm. ; October 6th, $12 \cdot 6$ gm., and November 6th, $15.7 \mathrm{gm}$., alternated with periods of slow rate, June 23rd, $0.9 \mathrm{gm}$. ; July 21st, $4.0 \mathrm{gm}$., and October 23rd, -0.2 gm., growth in length paralleling growth in weight (Table 29). Food rations were much more regular than weight increases, so that efficiency must have varied widely from time to time. Similar general results hold good for the male 
M2, which, however, showed increasing degrees of growth, appetite and efficiency as the experiment proceeded (Table 30).

The results for the females M3 and M4 are very similar to those for the W T. GM .

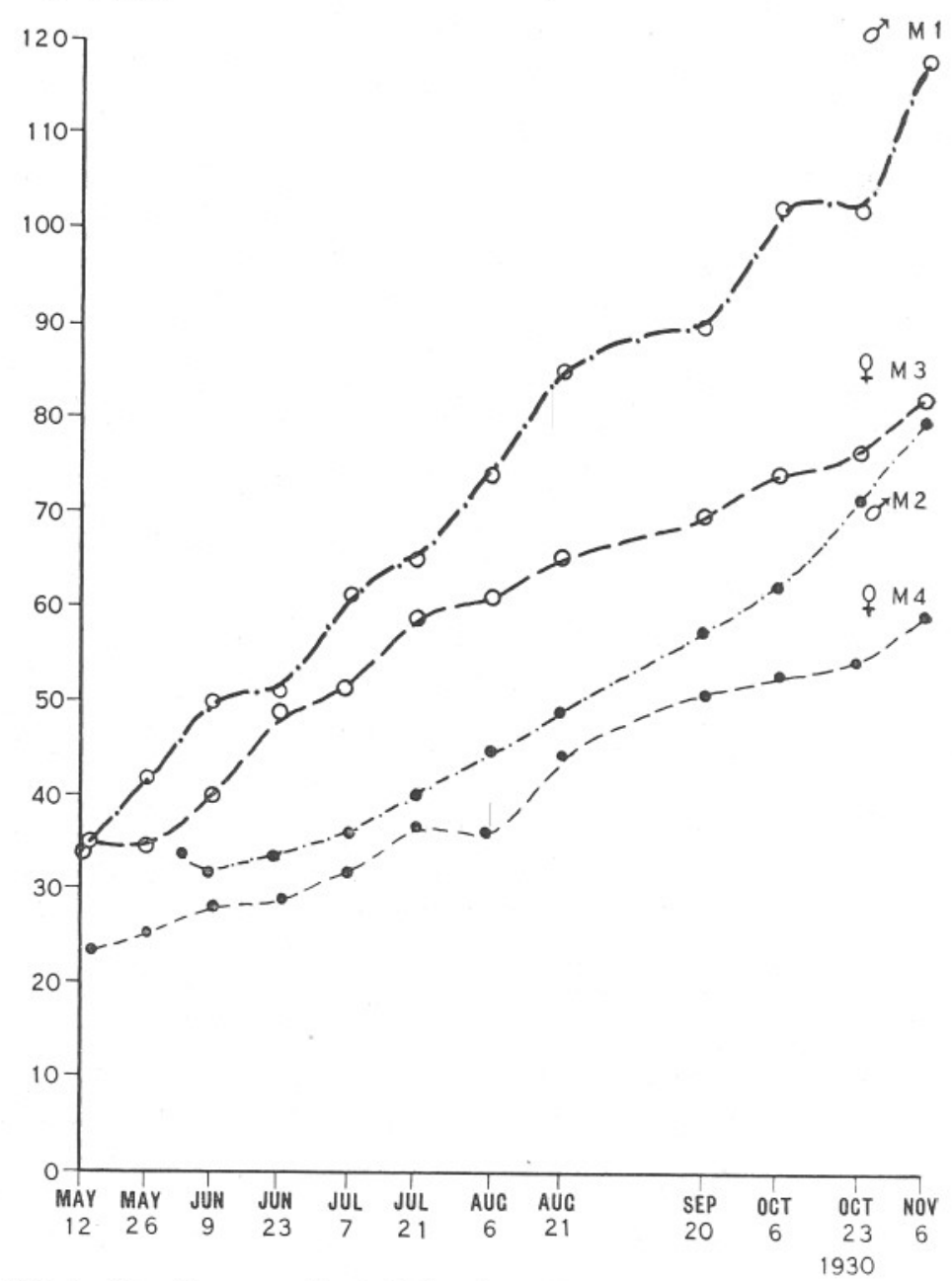

FIG. 4.-Growth curves of weight for the male plaice M1 and M2 and for the female plaice M3 and M4 (Cawsand, 1930).

males. Considerable differences are shown in the degree of giowth, appetite, and efficiency occurring during different periods. These results are shown in detail in Tables 31 and 32.

It is evident from the foregoing description that the $\mathrm{M}$ fish do not display a rate of growth markedly different from that of the $D$ and $B$ fish, so 
that we are able to assert that the conditions of life in the boxes containing the former fish are not markedly superior to those containing the latter, which are the modified boxes with reduced windows of minimum-sized mesh. In maximum-fed fish generally, the growth-rate during 1930 was slower than during 1929, no matter whether we consider the experiments with $\mathrm{D}$ and $\mathrm{B}$ fish, or those with $\mathrm{M}$ fish of the latter year. This was doubtless due to factors other than those arising out of the methods of experimenting and the type of accommodation afforded the fish.

\section{Growth and Intermediate Food Supplies.}

The results of the experiments with $\mathrm{M}$ fish indicate the necessity for looking beyond the experiments of 1928 for a satisfactory answer to the question as to whether intermediate-fed fish utilise food more efficiently than do maximum-fed fish. Fortunately, this question was investigated as a separate concern during 1930 . Two fish of each sex were kept segregated in one of the modified boxes and were supplied with rations intermediate in quantity between maintenance and maximum rations, and roughly twice the value of the former. Apart from the size of rations, these fishes were treated in exactly the same manner as maximum-fed fish and lived under similar conditions, so that it is perfectly legitimate to compare the rate of growth and degree of efficiency with the corresponding characteristics in the case of $\mathrm{D}$ and $\mathrm{B}$ fish. In the description which is to follow, these fish will be referred to as I fish, I1 and I2 being males, I3 and I4 females.

The summarised results of these experiments are shown in Table 33, where it is seen that for periods of 141-178 days, an average daily ration of not more than $1.5 \mathrm{gm}$. was provided. In the cases of the D and B fish as much as $3.5 \mathrm{gm}$. per day was taken. It is seen also that for the whole range of the experiments the I fish showed an unmistakably higher degree of efficiency than was shown by the D and B fish. No fish of the latter categories approached an efficiency such as is indicated by the indices $6 \cdot 8,6 \cdot 3$, and $5 \cdot 9$ for $\mathrm{I} 1, \mathrm{I} 3$, and I4 respectively. I2 showed relatively high efficiency (index 10.5), which was surpassed, however, by that of D4, B3, and B5 (indices $9 \cdot 1,9 \cdot 7$, and $8 \cdot 5$ respectively).

The detailed results of the experiments are presented in Tables 34-37. In the first of these, it is seen that I1 showed consistently high efficiency from June 13th to October 6th, the greatest index during this period of 98 days being $8 \cdot 6$, while during each of four periods the index was less than $5 \cdot 0$. By way of contrast it might be pointed out that during the whole series of experiments with six D fish, the index of efficiency was smaller than 5.0 during a total of only four periods. I1 also showed a rapid growth-rate, and almost doubled its initial weight of $33.7 \mathrm{gm}$. over a period of 146 days. I2, the remaining male, was not a particularly 
efficiently growing fish, but it showed an efficiency index smaller than $9 \cdot 0$ on four occasions, neglecting the index for the period ending June 23rd. This last index is extraordinarily small and perhaps of doubtful accuracy, there being the possibility of weighing error during the previous period, although length records suggest that this view is not fully justified (Table 35). Fusing the two periods between May 26th and June 23rd yields an index of 5.4 for the month, showing that in any case this fish showed a very high degree of efficiency about this time.

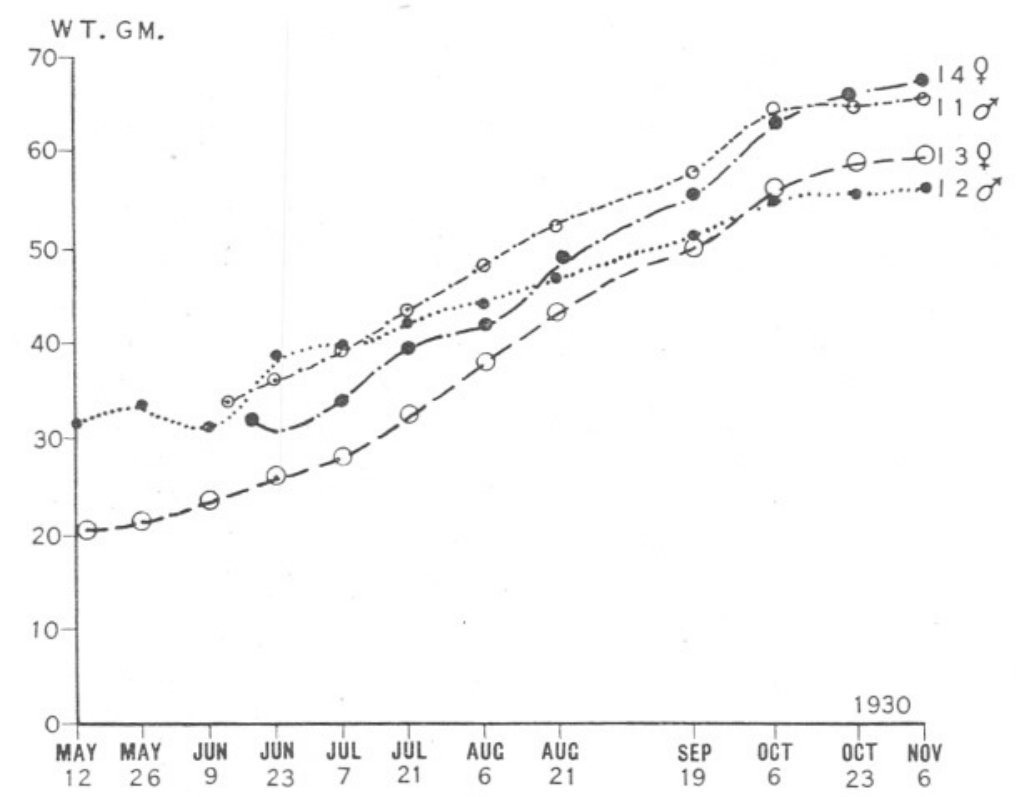

FIG. 5.-Growth curves of weight for the male plaice I1 and I2 and for the female plaice I3 and I4, fish supplied with intermediate rations (Cawsand, 1930).

Turning to the females we find in I3 a most surprisingly efficient fish. In Table 36 it is seen that during one period only $3.8 \mathrm{gm}$. of food were required to produce $1.0 \mathrm{gm}$. increase in weight (July 21st). During three other periods, the efficiency index was smaller than 5.0 and during three others it was less than $6 \cdot 0$. It is readily seen to be far more efficient than any one of the $\mathrm{B}$ fish. During 176 days the initial weight of this fish was almost tripled (Tables 33 and 36). I4 showed more variable efficiency, which however was generally distinctly high. Table 37 shows that the efficiency index was 3.1 during one period, 4.5 or smaller during three others, and the largest index for the whole experiment was $10 \cdot 8$. This fish easily doubled its initial weight over a period of 141 days (Table 33). 
Examination of the data of these experiments on intermediate feeding shows that whether we consider efficiency over periods of 141-178 days or for much shorter periods, there is considerable justification for the conclusion that male and female plaice alike make relatively much more efficient use of food for purposes of growth when supplied with rations intermediate between their maintenance requirements and maximum demands and roughly twice the value of the former than when maximum quantities of food are supplied to them. Among such intermediate-fed fish, not only are efficiency indices of $4 \cdot 0-5 \cdot 0$ more common, but there is also less variation in efficiency, the larger figures met with among the

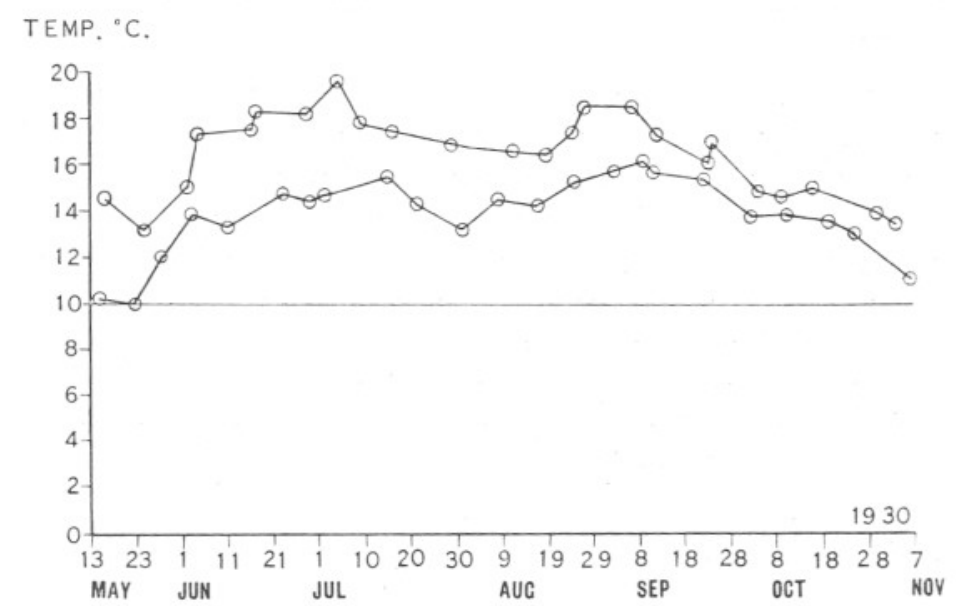

FIG. 6.-Graph of maximum and minimum temperatures at Cawsand, 1930.

indices for maximum-fed fish being absent. In the case of the four plaice we have considered, only during 12 periods out of a total of 40 was the efficiency index greater than $10 \cdot 0$, which fact in itself is much more than merely a suggestion of consistently high efficiency. The growth curves of weight for these fishes are presented in Figure 5 .

Figure 6 shows graphically the temperature range at Cawsand during 1930, minimum and maximum temperatures being plotted against time.

\section{Conclusions Drawn from the Experiments of 1930 (CAWsand).}

(1) A male plaice $13.1 \mathrm{~cm}$. in length and $21.5 \mathrm{gm}$. in weight was able to maintain its weight to within $0.7 \mathrm{gm}$. of constancy over a period of 144 days from May 14th, 1930, on an average daily ration of $0 \cdot 46 \mathrm{gm}$. of Mytilus flesh, which gives a maintenance ratio, i.e. the ratio food consumed per day/mid-body weight, of $0 \cdot 022$. These values would hold good for a fish just commencing its third season of growth. 
(2) Increasingly large fish require larger daily rations for purposes of maintenance, but increase in size of these rations is not directly proportional to increase in body-weight. Experiments with a graded series of fish of various sizes characterising the third season of growth show that the maintenance ratio decreases with increase in size of fish. Thus, passing to the upper limit of the series, a male plaice $23.0 \mathrm{~cm}$. in length and $115.0 \mathrm{gm}$. in weight was able to maintain its weight to within $4.0 \mathrm{gm}$. of constancy over a period of 147 days from June 12th, 1930, on an average daily ration of $1.42 \mathrm{gm}$. of similar food, thus showing a maintenance ratio of $0 \cdot 012$. These values would hold good for a male fish just ending its third season of growth.

(3) The values given above vary from one fortnightly period to another throughout the year, but it is suggested that a reasonably accurate estimate of the increasing maintenance requirements of a freelygrowing, two-year-old male plaice would be afforded by accepting the averages for long periods such as the above, excluding the winter months of low temperatures. Thus the maintenance requirements of such a fish would vary between $0.46 \mathrm{gm}$. and $1.42 \mathrm{gm}$. of Mytilus flesh per day, the maintenance ratio decreasing from 0.022 to 0.012 , approximately. Intermediate values are presented in the text and, graphically, in Figure 1.

(4) A female plaice $12 \cdot 2 \mathrm{~cm}$. in length and $17 \cdot 3 \mathrm{gm}$. in weight was able to maintain its weight to within $4 \cdot 7 \mathrm{gm}$. of constancy over a period of 143 days from June 16th, 1930, on an average daily ration of $0.43 \mathrm{gm}$. of similar food, thus showing a maintenance ratio of 0.022 . Thus the maintenance requirements of male and female plaice just commencing the third season of growth appear to be almost if not quite identical.

(5) Among females, as among males, the maintenance ratio decreases with increase in size of fish. Thus, passing to the upper limit of a graded series of fish chosen to represent stages in the third season of growth, a female plaice, $24.5 \mathrm{~cm}$. in length and $132.0 \mathrm{gm}$. in weight, was able to maintain its weight to within $4.9 \mathrm{gm}$. of constancy over a period of 178 days from May 12th, 1930, on an average daily ration of $1.24 \mathrm{gm}$. This value would hold good, approximately, for a fish just ending its third year of growth.

(6) From (4) and (5) it may reasonably be assumed that the maintenance requirements of a freely-growing female plaice would vary, during the third season of growth, between approximately $0.43 \mathrm{gm}$. and $1.24 \mathrm{gm}$. of Mytilus flesh per day, if growth were as unrestricted as for example at Cawsand during 1928. The main- 
tenance ratio would vary between 0.022 and 0.009 approximately, steadily falling to the latter value. Intermediate values are presented in the text and, graphically, in Figure 1.

(7) Growth of maximum-feeding plaice at Cawsand was poor during 1930 and the rate of growth was much more irregular than it was during 1929. But the results of the experiments with such fish lend support to the conclusions put forward earlier, that growth and efficiency (as indicated by the quantity of food required to produce $1.0 \mathrm{gm}$. increase in fish weight) vary very considerably in both males and females, from one fortnight to another throughout the growth season. During certain fortnightly periods, but rarely, such high efficiency as is shown by the indices $4 \cdot 7$ (B1), $4 \cdot 8$ (B2), $4 \cdot 2$ (D1 and D3), $4 \cdot 3$ (D2), and $4 \cdot 4$ (D4) was indicated, but during many periods the efficiency shown was very much lower. Thus among males, during 30 periods out of a total of 52 , more than $10 \cdot 0 \mathrm{gm}$. of food was required to bring about an increase in weight of $1.0 \mathrm{gm}$., and during 13 of these, more than $15.0 \mathrm{gm}$. was required. Among females more than $10.0 \mathrm{gm}$. was required during 26 periods out of a total of 54 ; during 18 of these, more than $15.0 \mathrm{gm}$. was required.

(8) It has been shown that during the experiments of 1928, there was possibly some leakage of food materials through the coarse meshwork of the box windows, and it is concluded that the efficiency of maximum-feeding fish was higher during this year than the experimental results indicate. This finding also affects the conclusion previously ventured that intermediate-feeding fish show a greater efficiency in the utilisation of food for purposes of growth than maximum-feeding fish. But this matter was investigated independently during 1930, the conclusions formed being shown below (9).

(9) Evidences have been presented which support the conclusion that male and female plaice alike, when supplied with rations intermediate in value between maintenance and maximum rations and about twice the value of the former, utilise food more efficiently for purposes of growth than fish which receive maximum rations. For periods of 141-176 days, the efficiency indices of three fish fed

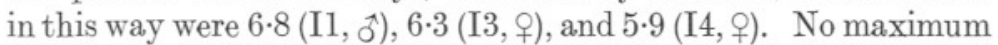
feeding plaice show such consistently high efficiency as this, the smallest indices for a corresponding period during 1930 in the case of such fish were $9 \cdot 1(\mathrm{D} 4, \widehat{\jmath})$ and 8.5 (B5, ㅇ). Moreover, indices, for fortnightly periods, of less than $5 \cdot 0$ were much more common among intermediate-feeding fish, 13 out of a possible total of 40 as against 7 out of a possible 106 for maximum-feeding fish. Similarly 
for indices less than $10 \cdot 0,28$ out of a possible 40 as against 48 out of a possible 106. Stated slightly differently, intermediate-feeding plaice required more than $10 \cdot 0 \mathrm{gm}$. of food for the production of $1.0 \mathrm{gm}$. of fish doing only 12 periods out of 40 , maximum-feeding plaice during 58 periods out of 106 . In the light of this evidence the conclusion of consistently higher efficiency seems perfectly justified.

\section{RESULTS OF THE LYMPSTONE EXPERIMENTS OF 1930.}

\section{Experiments of January to April.}

These experiments were really a direct continuation of the experiments of 1929, and thanks are due to Mr. Lees for facing the unpleasantness of winter in continuing the routine observations. As a glance at my previous paper will show, the experiments of 1929 concerned four maintained fish of each sex and four fully-growing fish of each sex. Of these, two of each sex in each group were retained for the work to be described presently, namely, L1 and L4 ( $\widehat{\jmath})$, and L5 and L7 (ㅇ) of the maintained groups, L10 and L12 ( $(\widehat{)})$ and L13 and L15 (ㅇ) of the freely-growing groups. All these fish were supplied with maintenance rations until summer feeding commenced, when the four latter fish were supplied with full rations. But as long as they declined food, only very small rations were offered so as to reduce the possibility of error, these rations being steadily increased according to appetite as soon as the fish showed signs of taking food readily. The results of these experiments will be described as briefly as possible, but they may be readily grasped by reference to the tables cited.

Maintenance requirements will be indicated by noting rations which result in loss of weight or allow of increase in weight and by considering that these quantities mark the experimental limits of maintenance.

Llw (init. lth. $17.6 \mathrm{~cm}$; init. wt. $52.8 \mathrm{gm}$.) during January and February required $0.44-0.61 \mathrm{gm}$. of food per day for maintenance (Table 38), the maintenance ratio corresponding to these figures being $0 \cdot 009-0 \cdot 012$. During later months the value of the ratio rose to $0 \cdot 014$ $0 \cdot 015$. L4w (init. lth. $21 \cdot 1 \mathrm{~cm}$. ; init. wt. $78 \cdot 8 \mathrm{gm}$.) during the first 42 days required a daily ration of $0.77-0.78 \mathrm{gm}$., the maintenance ratio being $0 \cdot 010$. During the latter part of the experiment these quantities had risen to $1 \cdot 10 \mathrm{gm}$. and 0.014 (Table 39). The female L5w (init. Ith. $18.9 \mathrm{~cm}$. ; init. wt. $69.8 \mathrm{gm}$.) took rather more food than was required for pure maintenance and consequently it is more difficult to fix maintenance requirements. But during the early stages of the experiment $0 \cdot 43-0.64 \mathrm{gm}$. seemed to be the daily ration required, giving a ratio of 0.006-0.009 (Table 40). L7w (init. lth. $22 \cdot 7$ cm. ; init. wt. $103 \cdot 4$ gm.) took rather less food than it needed for maintenance and declined 
in weight. During the colder months the maintenance requirements were $0 \cdot 64-0.96 \mathrm{gm}$. of food daily, which gives a ratio of $0 \cdot 006-0.009$ (Table 41).

In Table 42, the above results are summarised for the whole period of 112 days and included in the table are data from my previous paper showing the maintenance requirements of the same fishes during 1929 to November 25th, so that the decrease in value of the maintenance rations can readily be seen. In the first example, that of $\mathrm{L} 1$, the daily ration required for purposes of maintenance fell from $0.90 \mathrm{gm}$. to $0.58 \mathrm{gm}$. during the colder months, the maintenance ratio from $0 \cdot 017-0 \cdot 011$. Other examples will be found in the table.

The plaice which had been maximum-feeding and freely-growing previously, ceased to feed during early November, as is shown in my previous paper, and immediately commenced to lose weight. Having ceased to take maximum rations, these fish characteristically refused even mere maintenance rations. Thus during 56 days from January 6 th, it is doubtful if L10w-L15w took food at all (Table 43). On the other hand, minimum-feeding fish continued to take food throughout the colder months, during 56 days from January 6th, the average daily rations taken by $\mathrm{L} 1 \mathrm{w}-\mathrm{L} 7 \mathrm{w}$ ranging from $0 \cdot 61-0.91 \mathrm{gm}$. (Table 43 ). It is interesting to note also that the losses in weight shown by these non-feeding fishes were not very much greater than those of imperfectly maintained fish (see table). This is the most striking feature of the winter experiments.

The data of the experiments with previously maximum-feeding fish are presented in Tables 44-47. In all cases, it will be seen, feeding has been resumed completely before the end of March. In every case, little more than a maintenance ration was taken daily from February 17th to March 3rd. During the next fortnight the daily ration accepted increased until by March 17th the fish were almost fully-feeding. These findings present no new knowledge, but they do tend to show that the experimental fish behaved in very much the same way as do fish living under natural conditions, which speaks well for the experimental conditions.

When feeding was resumed, the fish at once showed increases in weight and corresponding to these, remarkably high degrees of efficiency, especially during the first fortnight of partially-resumed feeding. [Note : the efficiency index of L15 (Table 47) is misleading, since weight increases are undoubtedly due to ripening of the gonads.]

\section{Minimum Requirements and Maintenance.}

The results of the experiments on maintenance in male plaice are shown in Tables 48-51, the fish being referred to as L1-L4 respectively. These fish were much larger than the corresponding ones at Cawsand and their maintenance requirements would appear to be those of a fully-growing 
plaice at about the middle of its third season, in the larger ones towards the end of this season.

The maintenance requirements of L1 (init. lth. $17.9 \mathrm{~cm}$.; init. wt. $62.2 \mathrm{gm}$.) lay between $0.71 \mathrm{gm}$. and $0.98 \mathrm{gm}$. of food per day from one fortnightly period to another, giving a maintenance ratio of 0.012 0.017 (Table 48). For the whole experiment (182 days) an average daily ration of $0.86 \mathrm{gm}$. was slightly too small to maintain the weight constant, the corresponding ratio, $0 \cdot 015$, being slightly low (Table 52). For L2 (init. lth. $20.0 \mathrm{~cm}$; init. wt. $65.0 \mathrm{gm}$.) the daily maintenance ration lay between $0.83 \mathrm{gm}$. and 1-14 gm., the ratio between 0.012 and 0.019 (Table 49). Over a period of 182 days an average daily ration of $1.03 \mathrm{gm}$. allowed of a slight increase in weight, so that the ratio 0.015 is a trifle high (Table 52). L3 (init. lth. $21.5 \mathrm{~cm}$. ; init. wt. $90 \cdot 3 \mathrm{gm}$.) consistently lost weight to a great extent although the average daily ration taken over a period of 182 days was $1.09 \mathrm{gm}$., the maintenance ratio 0.013 , both of which figures are high by comparison with those for C5 (cp. Tables 50 and 5). L4a (init, lth. $18.5 \mathrm{~cm}$. ; init. wt. $65.5 \mathrm{gm}$.) required $0.82 \mathrm{gm}$. of food per day for maintenance, the corresponding ratio being 0.013 (Table 51, July 7 th and 21st). L4b (init. lth. $24 \cdot 4 \mathrm{~cm}$. ; init. wt. $149 \cdot 6 \mathrm{gm}$.) was undoubtedly a three-year-old fish. It required a daily ration of $0.87 \mathrm{gm}$. for maintenance during the fortnight ending November 10th, a very low value indeed, giving a ratio of 0.006 (Table 51). These results are summarised to November 10th in Table 52, where it is seen that the requirements of L1 alone compare closely with those of Cawsand males (Table 7).

Data concerning the experiments with the females L5-L8 are shown in Tables 53-56. L5 (init. lth. $14.7 \mathrm{~cm}$. ; init. wt. $28.9 \mathrm{gm}$.$) showed$ exceptionally high maintenance requirements (0.80-0.82 gm. per day) (Table 53). Over a period of 182 days an average daily ration of $0.78 \mathrm{gm}$. was required to maintain the weight constant, the maintenance ratio being as great as 0.027 (Table 57). The data for the remaining females are not of particular interest, and examination of the tables cited will show that the Lympstone results are far less satisfactory and useful than the results of the corresponding experiments at Cawsand. In fact, this statement might be extended to the Lympstone results in general as regards the maintenance experiments. The variations in quantity of the maintenance requirements of the Lympstone plaice are exceptionally wide and the results when examined closely are decidedly discordant. Losses in weight of rather serious proportions were more common than at Cawsand and these detract from the value of the results. Yet it must be remembered that it is not invariably as easy as one might assume to maintain the weights of segregated fish constant since they often decline to take food. 


\section{Maximum Requirements and Growth.}

Summarised data derived from the results of the Lympstone experiments with maximum-feeding plaice are presented in Table 58. The fish, it will be noticed, are generally much larger than those used at Cawsand and most of them are, in all probability, three and not two years old at the

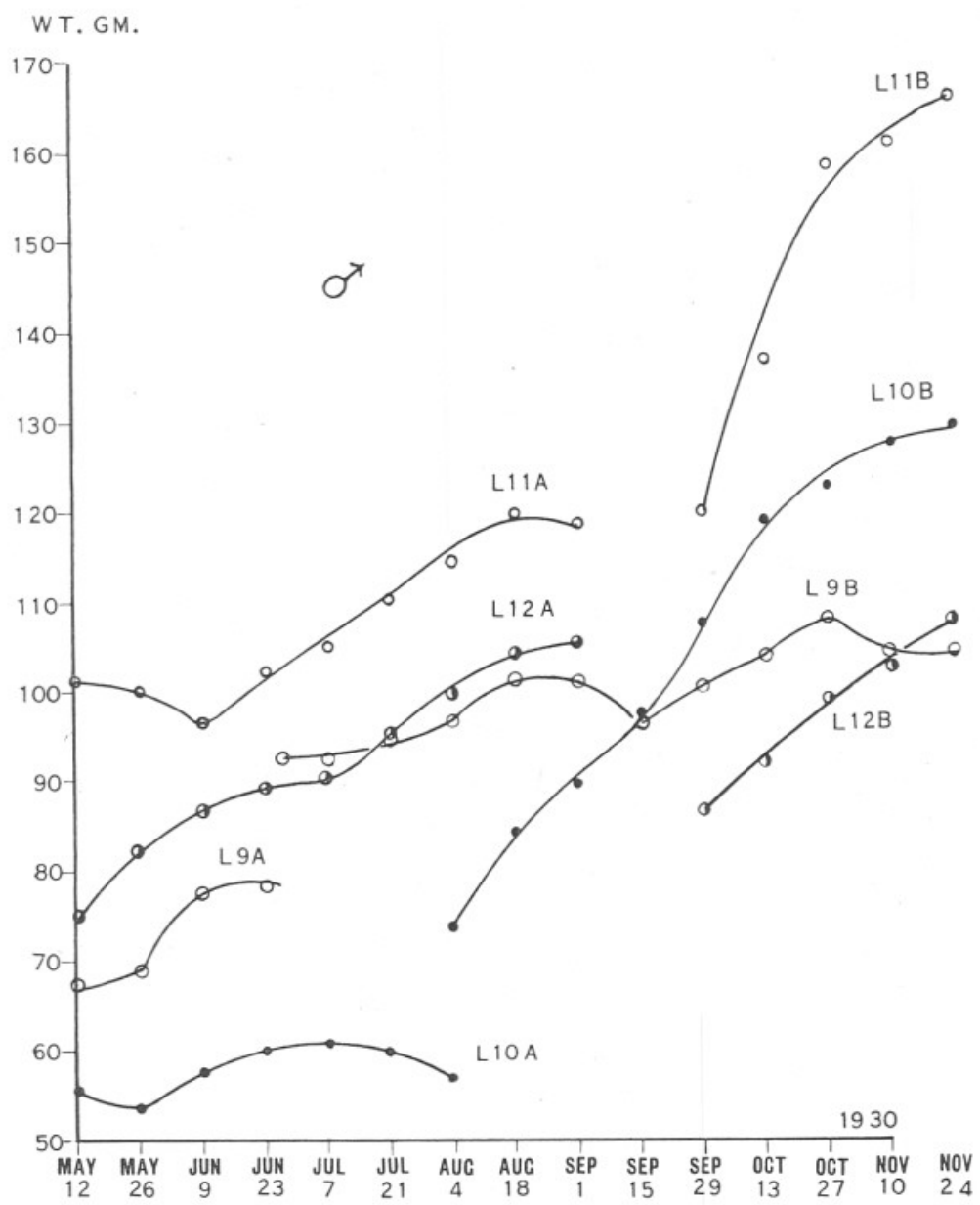

Fig. 7.-Growth curves of weight for the male plaice L9-L12 (Lympstone, 1930).

outset. Such data should provide a useful supplement to those of Cawsand. Unfortunately, in all cases save two the continuity of the experiments was broken, and it was necessary to employ two fishes instead of a single one. The growth-curves of weight for these fishes are shown in Fig. 7 . 
WT. GM,

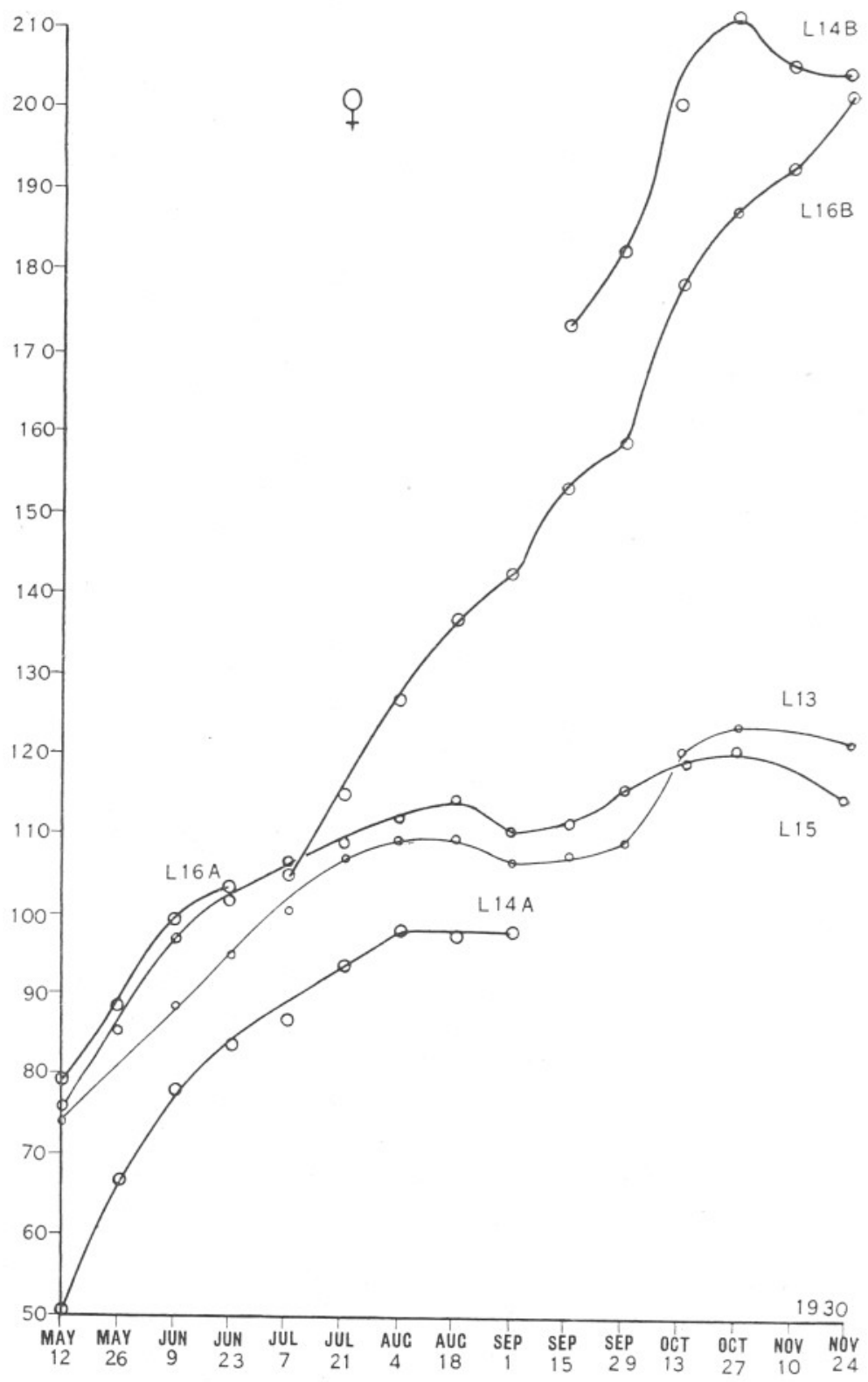

FIG. 8.-Growth curves of weight for the female plaice L13-L16 (Lympstone, 1930). 
It is seen from Table 58 that the growth rates of certain fishes were abnormally slow, e.g. those of L9b, L10a, and L11a. In these cases the efficiency indices were tremendously high, $45 \cdot 4,186 \cdot 1$, and $26 \cdot 6$ for periods of 84 or more days. Certain females also showed high indices, e.g. L13 $(20 \cdot 0)$ and L15 $(22 \cdot 4)$. A glance at these results shows conclusively that tremendous variation occurred in growth-rate and in efficiency in different individuals. As at Cawsand, the growth-rate was much slower than during 1929. Not a single fish rivalled the performances of L11, L15, and L16 of that year, which fish showed weight increases for a period of 154 days of $157 \cdot 4,140 \cdot 7$, and $175 \cdot 0 \mathrm{gm}$. respectively (see Table 41 of my previous paper). This statement might also be applied to efficiency, with slight

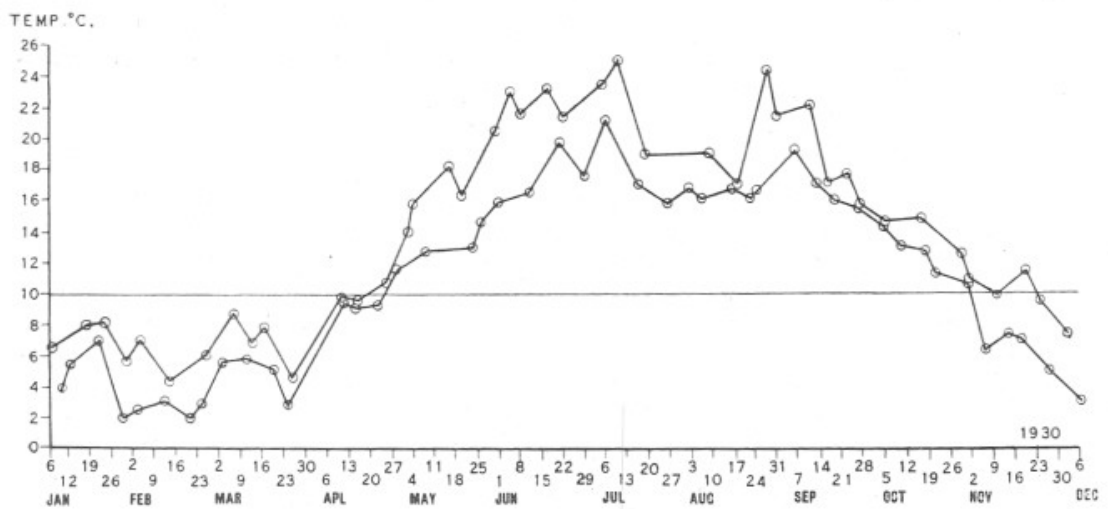

FIG. 9.-Graph of maximum and minimum temperatures at Lympstone, 1930.

reservation, since the fish mentioned showed indices of $7 \cdot 1,8 \cdot 1$, and $8 \cdot 5$. During 1930, L10b and L11b among males showed indices of $9 \cdot 6$ and 6.5 for periods of 98 and 42 days respectivly, L16a and $\mathrm{b}$ indices of 8.8 and $9 \cdot 4$ for periods of 42 and 126 days respectively, but no other fish showed such high efficiency as this over long periods (Table 58).

$\mathrm{L} 10 \mathrm{~b}$ showed a rapid growth-rate from one fortnightly period to another, with increments of $10 \cdot 4,7 \cdot 7,10 \cdot 2$, and $11 \cdot 4 \mathrm{gm}$. and corresponding efficiency indices of $5 \cdot 7,8 \cdot 7,8 \cdot 0$, and $8 \cdot 5$ (Table 60 ). But it had not doubled its initial weight at the end of 112 days. L11b showed the remarkable fortnightly weight increases of 16.8 and $21.6 \mathrm{gm}$., with such high efficiency as indices of 4.4 and 4.8 indicate, yet this phenomenal growthrate rapidly declined and during the next period only $2.3 \mathrm{gm}$. was added to the weight of the fish at a cost of $38.5 \mathrm{gm}$. of food per $1.0 \mathrm{gm}$. increase. These examples illustrate the slow rate of growth, variation in efficiency and irregularity of growth characterising the results of the Lympstone experiments with males. Other examples may be found readily in Tables 59-62. And these generalisations may well be applied to the 
females also, where great variation occurs as characteristically as among males. The results for the females are shown in Tables 63-66, where details may be inspected readily. The growth-curves of weight for these females are presented in Figure 8.

Figure 9 shows graphically the maximum and minimum temperatures recorded for weekly periods from January 6th to December 6th, 1930, the data employed having been kindly sent to me by Mr. H. Lees.

\section{Conclusions Drawn from the Experiments of 1930}

(Lympstone).

(1) The results of the experiments of January to April indicate the fall in value of the maintenance requirements of both male and female plaice during the coldest months of the year. By comparing these results with those obtained for the same fishes during 1929, we see that in the case of a male fish approximately $50 \mathrm{gm}$. in weight (e.g. L1) the average ration required daily for maintenance falls from $0.9 \mathrm{gm}$. to $0.6 \mathrm{gm}$., i.e. by about one-third of its former value. The maintenance ratio diminishes from $0 \cdot 017$ to $0 \cdot 011$. In the case of a female approximately $100 \mathrm{gm}$. in weight, the daily ration falls from $1.3 \mathrm{gm}$. to $0.7 \mathrm{gm}$., the maintenance ratio from 0.013 to 0.007 . The degree of reduction of these quantities varies considerably in different fish, but the results warrant the conclusion that during the colder months of the year, a plaice requires for purposes of maintenance only a fraction $\left(\frac{1}{2}\right.$ to $\left.\frac{2}{3}\right)$ of the daily ration which is required to maintain the weight constant during warmer monihs.

(2) These early experiments also serve to show that maximum-fed plaice of one summer refuse even mere maintenance rations during the following winter months, whereas previously minimum-fed fish continue to take maintenance rations. Moreover, the former fish appear to require much smaller quantities of food for purposes of maintenance during the winter than do the latter fish.

(3) It is shown that at Lympstone, maximum feeding was completely resumed before the end of March and that it was attained in little more than a fortnight. Growth commenced at once and strikingly high efficiency was shown during the first few weeks.

(4) At Lympstone during the summer of 1930, maintenance requirements were in some cases much higher than at Cawsand, which might be expected in view of the fact that water temperatures were higher. The results of maintenance experiments are inconsistent in their variability, however, although they tend to support the Cawsand results in showing the order of the fall in value of the maintenance ratio with increase in size of fish. 
(5) The growth-rate of maximum-feeding fish at Lympstone, as at Cawsand, was slow and the efficiency correspondingly low. These results similarly show the tremendous variation in rate of growth, and efficiency from one fortnightly period to another in the case of all fishes and from one fish to another at the same time. High efficiencies, e.g. 4.4 and 4.8 for L11b ; 4.5 and 6.8 for L13, wereshown from time to time, but rarely. Lower efficiencies were common, and among both males and females for at least one half: the total number of fortnightly periods, more than $15 \cdot 0 \mathrm{gm}$. of food was required to produce $1.0 \mathrm{gm}$. increase in weight of the fish. Among males the efficiency index was less than $10 \cdot 0$ during only 10 periods out of a total of 52 , among females during only 18 periods. out of a total of 54, clearly very low degrees of efficiency.

\section{GENERAL DISCUSSION OF RESULTS.}

The experiments on maintenance in the plaice, which have extended over three years, have on the whole rendered fairly uniform and very conclusive results. We may lay claim to a considerable body of facts, which shows with some precision the order of the maintenance requirements of a two years' old plaice, not only at the commencement of, but alsoduring and towards the end of the third season of growth. The results. of these experiments directly apply to different fish of various sizes, but by a process of analogy, to which objection can scarcely be raised, they can be applied to the same fish at different times during the growth season. with which we are concerned. Thus we arrive at an approximate evaluation of the maintenance requirements of fully-feeding, freely-growing plaice, using methods which are more in keeping with growth experiments. than others which might have been selected, e.g. determination of maintenance requirements by study of respiratory exchanges. Data are available also to show how maintenance requirements diminish during the months when water temperatures are lowest, when plaice which have been fully-feeding have ceased to take food to any considerable extent and con-. sequently have ceased to grow.

In a previous paper (Journ. Mar. Biol. Soc., Vol. XVII, No. 1, Sept. 1930, pp. 103-174) it was shown that the maintenance requirements of a. $44 \mathrm{gm}$. male plaice are satisfied when an average daily ration of $0 \cdot 6-0 \cdot 7 \mathrm{gm}$. of Mytilus flesh is injested, but reasons were given for supposing that this ration value is low and that a more accurate value would be $0.7-0.8 \mathrm{gm}$., or 0.018 of the body weight (=maintenance ratio). During 1929, this statement was substantiated, for it was found that a $42 \mathrm{gm}$. male fish, C6a, maintained its weight constant over a period of 131 days when it took an average daily ration of $0.7 \mathrm{gm}$., which yields a maintenance ratio. 
of $0 \cdot 017$. It was shown further that C5a, a $30 \mathrm{gm}$. male, required a daily ration of $0.6 \mathrm{gm}$. for purposes of maintenance $($ ratio $=0.019)$ and that the mean $\mathrm{C}$ fish, $17 \cdot 6 \mathrm{gm}$. in weight, required $0.4 \mathrm{gm}$. per day (ratio $=0.024$ ). This was the closest approach that could be made to a determination of the increase in value of maintenance requirements with increase in size of the fish when the results of the Cawsand experiments of 1929 alone were employed. But it was seen that the increase in value of these requirements is not directly proportional to the increase in size, the maintenance ratio decreasing in value. By combining these results with the Lympstone results of the same year, it was possible to proceed a little way further. The male L1, a $52 \mathrm{gm}$. fish, required a daily ration of $0.9 \mathrm{gm}$. (maintenance ratio $=0 \cdot 017$ ), while $\mathrm{L} 2$, a 130 -gm. male, required $1 \cdot 4 \mathrm{gm}$. per day (ratio $=$ $0 \cdot 011$ ). Indicating that objections might be raised to a combination of the two sets of results, the conclusion was nevertheless put forward that an increase in weight from $18 \mathrm{gm}$. to $130 \mathrm{gm}$. among male plaice entailed an increase in the daily ration required for maintenance from $0.4 \mathrm{gm}$. to 1.4 gm., which implies a decrease in the value of the maintenance ratio from $0 \cdot 024$ towards $0 \cdot 011$.

It is obviously both important and interesting to observe how far the results of 1930 conform to or depart from the conclusions ventured. Fortunately, at Cawsand during 1930, a far greater measure of success was met with in the experimental determination of maintenance requirements than had been met with during the previous two years, due to the arrangement of a graded series of individuals of various sizes representing stages passed through by a plaice during its third season of growth. And the results of this last year both strengthen and broaden the conclusions previously formed. In the text of this paper it has been shown that during 1930 , the maintenance requirements of a male plaice $21.5 \mathrm{gm}$. in weight were approximately $0.46 \mathrm{gm}$. of Mytilus flesh daily, those of a similar fish $115.0 \mathrm{gm}$. in weight approximately $1.42 \mathrm{gm}$. of such food per day. The maintenance ratios corresponding to these quantities are 0.022 and $0 \cdot 011$. The close conformity between these results and those of the previous year is clearly seen and is also noteworthy.

It was suggested further, that the size difference indicated above is a close measure of the difference shown by a two-year-old plaice at the commencement of and towards the end of its third season of growth. We have thus reached the point at which it is possible to conclude, and with much faith in the accuracy of the conclusion, that about the commencement of the third season of growth a male plaice requires approximately 0.022 body-weight, or the first $0.4 \mathrm{gm}$. of its daily ration, to satisfy basal requirements and maintain its weight constant, and that towards the end of this season 0.011 body-weight, or the first $1.4 \mathrm{gm}$. of the daily ration for this purpose. The food is understood to be Mytilus flesh. The 
variation in basal need with increase in size is presumably a steady one, so that it is possible to infer, with some experimental evidence to support the inference, that the maintenance ratio is a variable quantity which, during the season with which we are concerned, ranges from 0.022 towards $0 \cdot 011$. This is shown graphically from experimental results in Figure $1(\hat{\sigma})$.

For females, corresponding success was met with during the final years' work, the results substantiating and amplifying the conclusions previously ventured. In my previous paper it is seen that at Cawsand during 1929 a female $22 \mathrm{gm}$. in weight required $0.4 \mathrm{gm}$. of food per day for maintenance, a similar fish $42 \mathrm{gm}$. in weight required $0.6 \mathrm{gm}$., or expressed in the form of maintenance ratios 0.019 and 0.015 of the bodyweight respectively. A Lympstone female $103 \mathrm{gm}$. in weight required $1.3 \mathrm{gm}$. per day or 0.013 body-weight. The results of 1930 correspond more closely with those presented above for males. A female $17 \cdot 3 \mathrm{gm}$. in weight required $0.43 \mathrm{gm}$. of food per day, a similar fish of $132.0 \mathrm{gm}$. required 1.24 gm. per day, the corresponding ratios being 0.022 and 0.009 . The latter value appears to be subnormal in that the female A3, 101.5 gm. in weight, required 1.21 per day, yielding a maintenance ratio of 0.012 , and it is distinctly possible that the maintenance requirements of females parallel those of males. It is unlikely that serious error would arise if the maintenance ratio of a female $130 \mathrm{gm}$. in weight was taken as being $0 \cdot 011$. In Figure 1 the results of these experiments are shown graphically for females as well as for males. These results can be extended in the way indicated above for fully-growing males.

The growth-rate shown at Cawsand during 1928 was rapid, the mean male increasing its initial weight of $38.8 \mathrm{gm}$. by $86.0 \mathrm{gm}$., the mean female increasing its initial weight of $43.3 \mathrm{gm}$. by $107.9 \mathrm{gm}$. during a period of 176 days. But the efficiency of these fish, as measured by the quantity of food required to produce an increase of $1.0 \mathrm{gm}$. in weight, was low, the mean male requiring $12.7 \mathrm{gm}$. and the mean female $10.5 \mathrm{gm}$. In the present paper it has been shown that during these preliminary experiments it is likely that there was a slight leakage of food materials through the coarse mesh of the box windows during the ebb and flow of tides. If this was the case, the efficiency indices shown are slightly greater than the true values. When the conditions and apparatus were refined, the efficiency shown was much higher, i.e. the indices were smaller. Thus during 1929 the average efficiency of D3, the most rapidly-growing male, for a period of 175 days was represented by the index 6.5 , the average efficiencies of $\mathrm{B} 1$ and $\mathrm{B} 4$, the most rapidly-growing females, by the indices $7 \cdot 6$ and $7 \cdot 2$ respectively, over a corresponding period. Moreover, examination of the data for fortnightly periods showed that among Cawsand males, the efficiency was so high during certain periods as to yield an index of 4.8 and among the corresponding females an index of $5 \cdot 2$ was shown. 
At Lympstone the efficiencies over long periods were lower, that of the male L11 being $7 \cdot 1$, those of the females L15, and L16 being $8 \cdot 1$ and $8 \cdot 5$ respectively. As at Cawsand, and to an even greater extent, higher efficiencies were shown during certain fortnightly periods, and generally there was much more variation in efficiency from period to period than at Cawsand.

At Cawsand during 1930, the highest efficiency over long periods was shown by the male D4, with an index of $9 \cdot 1$ for 116 days and the females B3 and B5, with indices of $9 \cdot 7$ and 8.5 for 165 and 87 days respectively. If these values are compared with those given for D3, B1, and B4 of 1929 above, it is seen that they are slightly greater, i.e. the efficiencies during 1930 were slightly lower. But the efficiencies shown during 1930 were higher than those shown during 1928, and we can safely infer, on the evidences of the results of two consecutive years, that the maximum average efficiency for periods approaching whole growth seasons in extent lies between efficiencies corresponding to the indices 6.5 and $9 \cdot 1$ for males, and 7.2 and 8.5 for females. In view of the fact that the higher efficiencies went side by side with more rapid, and perhaps more nearly typical, growth-rates, it would probably be safe to infer that they are more accurate from the viewpoint of normality.

Growth proceeded at a rapid rate at Cawsand during 1928, as is mentioned above. Such rapid rates and degrees of growth have not been shown since 1928, either at Cawsand or at Lympstone. This applies with additional force if we consider individual performances at Cawsand during the first year, when the male $\mathrm{C} 3$ increased its weight from $36.0 \mathrm{gm}$. to $158.0 \mathrm{gm}$., and the female D5 from $50.0 \mathrm{gm}$. to $203.0 \mathrm{gm}$., both performances taking 176 days. Such weight increase has not been equalled although the percentage growth has been exceeded. As has been shown, the above plaice increased their initial weights by over 300 per cent, while the later experiments yielded smaller actual weight increases but higher percentages of growth. Thus the Cawsand male D3 of 1929 increased in weight from $15.5 \mathrm{gm}$. to $105.0 \mathrm{gm}$., the corresponding females B1 and B4 from $24.0 \mathrm{gm}$. to $105.5 \mathrm{gm}$. and from $18.5 \mathrm{gm}$. to $103.5 \mathrm{gm}$. respectively, during 175 days, percentage increases of 580,340 , and 460 respectively. Actual weight increase is our chief concern however. It is obvious that any figures for percentage growth call for uniform initial weights and periods. The experiments of 1929 were started earlier than those of 1928, and with smaller fish. This fact causes percentage growth of 1929 to appear greater than that of 1928 despite the actually smaller weight increases. At Lympstone during 1929, slightly larger fish were used and, over a period of 154 days, the male L11 increased in weight from $23.2 \mathrm{gm}$. to $157 \cdot 4 \mathrm{gm}$., the females L15 and L16 from $31.9 \mathrm{gm}$. to $140 \cdot 7 \mathrm{gm}$. and from $50 \cdot 5 \mathrm{gm}$. to $175 \cdot 0 \mathrm{gm}$. respectively. Only L11 equalled 
the performance of the Cawsand (1929) male C3 as regards actual weight increase.

For some reason which remains unknown, the rate of growth shown at both Cawsand and Lympstone during 1930 was much slower than that shown during 1929, degrees of growth being smaller also. The most actively-growing male, D1, increased in weight merely from $35.8 \mathrm{gm}$. to $77 \cdot 1 \mathrm{gm}$. during 162 days, the most actively-growing female, B5, from $34.5 \mathrm{gm}$. to $82.5 \mathrm{gm}$. during 87 days. At Lympstone, L10b showed weight increase from $73.9 \mathrm{gm}$. to $127.7 \mathrm{gm}$. during 98 days, the female L16b, a three years' old fish presumably, from $104 \cdot 9 \mathrm{gm}$. to $192 \cdot 8 \mathrm{gm}$. during 126 days. These fishes were the most actively-growing individuals at Lympsťone.

From the point of view of typical growth then, the results of 1930 are of much less value than those of the previous year. The experiments of 1929 are of most use in this respect, since they were commenced earlier in the year. But perhaps the best indication of maximum growth during the third season of the plaice is afforded when the results of 1929 are combined with those of 1928 , i.e. when an hypothetical fish is built up of two individuals of consecutive years, taking care, of course, that the two periods do not overlap. Thus, if we take D3 (1928) and B4 (1929) as characteristic of females, it is seen that from May 22nd to July 19th, 1929, B4 increased its weight from $18.5 \mathrm{gm}$. to $43 \cdot 0 \mathrm{gm}$., its length from $13.2 \mathrm{~cm}$. to $16 \cdot 1 \mathrm{~cm}$. On July 16th, 1928, i.e. at the commencement of the experiment, D3 was $16.6 \mathrm{~cm}$. in length and $43.0 \mathrm{gm}$. in weight. And it is reasonable to assume, bearing the performance of B4 in mind, that had the experiments of 1928 been commenced some 48 days earlier, they might have been commenced with a D3 fish of approximately $13 \mathrm{~cm}$. in length and $18 \mathrm{gm}$. in weight, this being the size of B4 on May 22nd, 1929. Even when two sets of results are combined in this way, the whole growth season is not completely covered since, according to the Lympstone results of 1930, plaice are fully-feeding and freely-growing by the end of March, but a closer approximation is afforded for total growth during the third season.

By this means we can infer that the theoretical D3 fish of May 22nd, 1928, increased in size until by the end of December growth had taken place from $13 \mathrm{~cm}$. and $18 \mathrm{gm}$. to $23.5 \mathrm{~cm}$. and $155 \mathrm{gm}$. It might be considered objectionable to estimate growth to the end of December since during 1929 growth ceased before the end of November, but it should be realised that the degree of growth during December was slight. Moreover, as the duration of this theoretical growth season (221 days) has not been extended beyond the normal span (see below), no serious error is involved.

It is possible to repeat the above in the case of males, and by thus combining the results for C3 (1928) and D3 (1929) we can infer that growth 
in weight from $15.5 \mathrm{gm}$. to $151 \mathrm{gm}$. takes place, theoretically, during the corresponding period. This approximation would hold as an index of maximum growth shown during the third season by a typical female. The method employed is open to objection, but the aim in view is an estimate of growth for the whole of the season with which we are concerned. Such methods will be discarded when it comes to attempting to estimate food requirements and food fractions going to satisfy maintenance requirements and to promote growth respectively. In attempting to do this the data of one particular year will be adhered to closely. Before leaving this question of total growth it might be mentioned that the Lympstone male, L11, increased in weight from $23 \cdot 2 \mathrm{gm}$. to $147 \cdot 2 \mathrm{gm}$. during 182 days ending December 23rd, 1929. This shows the estimates made above to be reasonable ones.

We might consider briefly Lympstone data which indicate the duration of the growth season. The results of the experiments of January to April show that the winter fast ceases quite abruptly during early March and that before the end of this month appetite is completely restored. About March 1st, 1930, the four Lympstone plaice L10-L15 were taking mere maintenance rations of approximately $2 \mathrm{gm}$. per day. On March 4 th they commenced to take 4-5 gm. per day, and by March 6th were taking 5-6 gm. per day. The daily rations by the end of the month were 6-7 gm. It is clear that during the first week in March these plaice increased their daily rations from maintenance ones to almost maximum ones. We may consider that the feeding and growth season commences about the end of this week, say March 6th. At Lympstone during 1929, feeding ceased abruptly about November 11th, when maximum water temperatures approached $10^{\circ} \mathrm{C}$., as the following data show. During the fortnight ending November 11th, L12, L13, and L15 took 50.0, 36.3, and $65.4 \mathrm{gm}$. of food respectively, while during the next fortnight only $8 \cdot 4,7 \cdot 2$, and $24 \cdot 8 \mathrm{gm}$. respectively was taken. L15 continued partial feeding until December, but it is generally true that full feeding was discontinued about November 11th. And in each case this discontinuance marks the onset of a period when loss in weight occurs. The period of winter fasting thus extends over 16 weeks and includes the whole of December, January, and February. For about 36 weeks full feeding and unrestricted growth ensue. The growth period is seen to be about 30 days longer in extent than that corresponding to the total growth estimate provided above. Doubtless, some variation in duration of the growth period occurs, and at Lympstone during 1930, feeding and growth proceeded longer than during 1929, but after November 10th, when maximum water temperatures reached $10^{\circ} \mathrm{C}$., feeding was partial, so that the above conclusions are not materially affected.

In my previous paper it was suggested that plaice which take food 
rations intermediate in quantity between maintenance and maximum rations utilise food more efficiently for purposes of growth than do maximum-feeding plaice. It has been shown in the present paper that the evidence upon which this conclusion was based proved to be of doubtful accuracy. There is a possibility that slight quantities of food were washed out of the boxes during the early experiments and, if this actually occurred, the efficiency of the maximum-feeding fish was higher than the data indicate. The efficiency of these fish was used as a basis of comparison for intermediate-feeding fish and hence the higher efficiencies were possibly more apparent than real. But during 1930, this question was investigated under refined conditions, and more reliable data have been obtained.

Two fish of each sex were housed, in a segregated condition, in the modified fish boxes and were supplied with rations about twice the value of the maintenance rations. It is seen in Table 33 that these fish took an average daily ration of not more than $1.5 \mathrm{gm}$. over periods from 141-178 days, whereas the maximum-feeding fish took as much as $3.5 \mathrm{gm}$. per day. For the whole range of the experiments the I fish (intermediate-feeding) showed an unmistakably high degree of efficiency in the utilisation of food for growth purposes. No D or B fish (maximum-feeding) showed such low efficiency indices, i.e. high efficiency, as was shown by these fish for long periods, e.g. $6 \cdot 8$ (I1), $6 \cdot 3$ (I3), or 5.9 (I4). The indices for the two most efficient D fish are $9 \cdot 1$ (D4) and $10 \cdot 2$ (D3), those for the most efficient B fish, 8.5 (B5) and $9 \cdot 7$ (B3). Thus the male I1 required $2 \cdot 3 \mathrm{gm}$. of food less than the male D4 did in order to increase its weight by $1.0 \mathrm{gm}$., the female I4 $2.6 \mathrm{gm}$. less than the female B5 for corresponding weight increase. The conclusion that intermediate-feeding plaice are more efficient than maximum-feeding plaice seems perfectly justified. The evidences are presented in greater detail in the text of this paper.

Finally, it is intended to attempt to fulfil the principal aim of these experiments, which is to determine what portion of the maximum ration taken by a freely-growing plaice is used in satisfying basal requirements, i.e. supporting life by supplying the energy necessary for its maintenance, for tissue repair and replacement, and what portion remains for the promotion of growth. The results of the preliminary experiments of 1928 are of little or no use in this attempt since within 14 days of the commencement the maximum-feeding male fish were larger than the minimum-feeding fish. As the latter were retained for the whole course of the experiments it is not possible to compare the two sets fairly. In the case of females there was no fair basis of comparison from the very outset, on account of size differences existing then. In my previous paper an attempt was made to estimate the maintenance requirements of the fully-growing males, but it was based upon the assumption that the maintenance ratio 
is constant throughout the third season of growth. Subsequent work has shown that such is not the case, the ratio decreasing with increase in size of the fish. But the estimate that approximately one-fifth of the total food ration was used in satisfying maintenance requirements compares as closely with the more refined estimate presented below as could be expected from the facts then available.

\section{TABLE 67.}

\section{Data Concerning the Male Plaice D3 (1929).}

Showing growth in weight, food taken, and variation in maintenance ratio with increasing size. Also food quantities estimated as having been used for purpose of maintenance, fraction of total food and efficiency as regards food available for growth.

\begin{tabular}{|c|c|c|c|c|c|c|c|c|}
\hline $\begin{array}{c}\text { Date } \\
(1929) .\end{array}$ & $\begin{array}{c}\text { Weight. } \\
\text { (gm.) }\end{array}$ & $\begin{array}{l}\text { Food } \\
\text { per } \\
\text { period. }\end{array}$ & $\begin{array}{l}\text { Main. } \\
\text { tenance } \\
\text { ratio } \\
\text { (from } \\
\text { Graph } \\
\text { Fig. 1). }\end{array}$ & $\begin{array}{r}\text { Days } \\
\text { in } \\
\text { period. }\end{array}$ & $\begin{array}{l}\text { Estimated } \\
\text { food } \\
\text { required } \\
\text { for main- } \\
\text { tenance } \\
\text { per period. } \\
\text { (gm.) }\end{array}$ & $\begin{array}{l}\text { Fraction of } \\
\text { total food } \\
\text { used for } \\
\text { mainten- } \\
\text { ance. }\end{array}$ & $\begin{array}{c}\text { Growth } \\
\text { in } \\
\text { weight } \\
\text { per } \\
\text { period. } \\
\text { (gm.) }\end{array}$ & $\begin{array}{l}\text { food re- } \\
\text { quired to } \\
\text { produce } \\
1 \cdot 0 \text { gm. } \\
\text { increase in } \\
\text { wt. of fish } \\
\text { allowing } \\
\text { for main- } \\
\text { tenance.) }\end{array}$ \\
\hline June 6 & $15 \cdot 5$ & - & - & - & - & - & - & - \\
\hline,$\quad 20$ & $18 \cdot 0$ & $22 \cdot 0$ & $0 \cdot 024$ & 14 & $6 \cdot 0$ & $0 \cdot 27$ & $2 \cdot 5$ & $6 \cdot 4$ \\
\hline July 5 & $22 \cdot 5$ & $26 \cdot 0$ & $0 \cdot 024$ & 15 & $7 \cdot 3$ & $0 \cdot 28$ & $4 \cdot 5$ & $4 \cdot 2$ \\
\hline,$\quad 19$ & $30 \cdot 0$ & $36 \cdot 0$ & $0 \cdot 020$ & 14 & $7 \cdot 4$ & $0 \cdot 21$ & $7 \cdot 5$ & $3 \cdot 8$ \\
\hline Aug. 2 & $37 \cdot 0$ & $41 \cdot 4$ & $0 \cdot 018$ & 14 & $8 \cdot 4$ & $0 \cdot 20$ & $7 \cdot 0$ & $4 \cdot 7$ \\
\hline,,$\quad 16$ & $41 \cdot 5$ & $44 \cdot 2$ & $0 \cdot 0165$ & 14 & $9 \cdot 0$ & $0 \cdot 20$ & $4 \cdot 5$ & $7 \cdot 8$ \\
\hline,$\quad 30$ & $51 \cdot 5$ & $53 \cdot 2$ & $0 \cdot 015$ & 14 & $9 \cdot 8$ & $0 \cdot 18$ & $10 \cdot 0$ & $4 \cdot 3$ \\
\hline Sept. 16 & $65 \cdot 5$ & $68 \cdot 5$ & 0.014 & 17 & $13 \cdot 9$ & $0 \cdot 20$ & $14 \cdot 0$ & $3 \cdot 9$ \\
\hline Oct. 1 & $79 \cdot 0$ & $65 \cdot 2$ & $0 \cdot 0135$ & 15 & $14 \cdot 6$ & $0 \cdot 22$ & $13 \cdot 5$ & $3 \cdot 7$ \\
\hline,$\quad 15$ & $90 \cdot 0$ & $76 \cdot 5$ & $0 \cdot 013$ & 14 & $15 \cdot 4$ & $0 \cdot 20$ & $11 \cdot 0$ & $5 \cdot 6$ \\
\hline ,, 29 & $95 \cdot 0$ & $63 \cdot 0$ & $0 \cdot 0125$ & 14 & $16 \cdot 2$ & $0 \cdot 26$ & $5 \cdot 0$ & $9 \cdot 4$ \\
\hline Nov. 13 & $103 \cdot 0$ & $50 \cdot 0$ & $0 \cdot 012$ & 15 & $17 \cdot 8$ & $0 \cdot 36$ & $8 \cdot 0$ & $4 \cdot 0$ \\
\hline,$\quad 28$ & $105 \cdot 0$ & $39 \cdot 0$ & $0 \cdot 012$ & 15 & $18 \cdot 7$ & $0 \cdot 48$ & $2 \cdot 0$ & $10 \cdot 1$ \\
\hline
\end{tabular}

During 1929 an attempt was made to remedy the defects of the early experiments by determining the maintenance requirements of fish of different sizes, but the attempt was not completely successful. It was intended to commence the experiments with minimum and maximumfeeding plaice of about the same size and to change the former periodically so as to be able to keep the sizes comparable throughout, but difficulty 
was met with in the substitution of freshly-trawled fish for settled fish. The fish appear to require a period of time in which to settle down and segregation is not conducive to rapid settling down. However, the results of these experiments provided the valuable conclusions which have been mentioned above. Considerable advance was made during 1930 at

\section{TABLE 68.}

\section{Data Concerning the Female Plaice B1 (1929).}

Showing growth in weight, food taken, and variation in maintenance ratio with increasing size. Also food quantities estimated as having been used for purpose of maintenance, fraction of total food and efficiency as regards food available for growth.

\begin{tabular}{|c|c|c|c|c|c|c|c|c|}
\hline $\begin{array}{c}\text { Date } \\
(1929) .\end{array}$ & $\begin{array}{c}\text { Weight. } \\
\text { (gm.) }\end{array}$ & $\begin{array}{c}\text { Food } \\
\text { per } \\
\text { period. }\end{array}$ & $\begin{array}{l}\text { Main- } \\
\text { tenance } \\
\text { ratio } \\
\text { (from } \\
\text { Graph } \\
\text { Fig. 1). }\end{array}$ & $\begin{array}{r}\begin{array}{c}\text { Days } \\
\text { in } \\
\text { period. }\end{array} \\
\\
\text { P }\end{array}$ & $\begin{array}{l}\text { Estimated } \\
\quad \text { food } \\
\text { required } \\
\text { for main- } \\
\text { tenance } \\
\text { per period. } \\
\text { (gm.) }\end{array}$ & $\begin{array}{l}\text { d } \\
\text { Fraction of } \\
\text { total food } \\
\text { used for } \\
\text { mainten- } \\
\text { ance. }\end{array}$ & $\begin{array}{l}\text { Growth } \\
\text { in } \\
\text { weight } \\
\text { per } \\
\text { period. } \\
\text { (gm.) }\end{array}$ & $\begin{array}{l}\text { quired to } \\
\text { produce } \\
1.0 \mathrm{gm} . \\
\text { increase in } \\
\text { wt. of fish } \\
\text { allowing } \\
\text { for main. } \\
\text { tenance.) }\end{array}$ \\
\hline May 22 & $24 \cdot 0$ & - & - & - & - & - & - & - \\
\hline June 6 & $31 \cdot 0$ & $40 \cdot 0$ & $0 \cdot 019$ & 15 & $7 \cdot 8$ & $0 \cdot 20$ & $7 \cdot 0$ & $4 \cdot 6$ \\
\hline,,$\quad 20$ & $35 \cdot 0$ & $22 \cdot 0$ & $0 \cdot 017$ & 14 & $7 \cdot 9$ & $0 \cdot 36$ & $4 \cdot 0$ & $3 \cdot 5$ \\
\hline July 5 & $40 \cdot 0$ & $26 \cdot 0$ & $0 \cdot 016$ & 15 & $9 \cdot 0$ & $0 \cdot 35$ & $5 \cdot 0$ & $3 \cdot 4$ \\
\hline,,$\quad 19$ & $47 \cdot 0$ & $38 \cdot 0$ & $0 \cdot 015$ & 14 & $9 \cdot 1$ & $0 \cdot 24$ & $7 \cdot 0$ & $4 \cdot 1$ \\
\hline Aug. 2 & $53 \cdot 5$ & $44 \cdot 3$ & $0 \cdot 014$ & 14 & $9 \cdot 8$ & $0 \cdot 22$ & $6 \cdot 5$ & $5 \cdot 3$ \\
\hline,,$\quad 16$ & $61 \cdot 0$ & $46 \cdot 2$ & 0.0135 & 14 & $10 \cdot 6$ & $0 \cdot 23$ & $7 \cdot 5$ & $4 \cdot 7$ \\
\hline , $\quad 30$ & $69 \cdot 0$ & $57 \cdot 0$ & $0 \cdot 0125$ & 14 & $12 \cdot 0$ & $0 \cdot 21$ & $8 \cdot 0$ & $5 \cdot 6$ \\
\hline Sept. 16 & $79 \cdot 5$ & $69 \cdot 0$ & $0 \cdot 012$ & 17 & $15 \cdot 1$ & $0 \cdot 22$ & $10 \cdot 5$ & $5 \cdot 1$ \\
\hline Oct. 1 & $89 \cdot 5$ & $66 \cdot 9$ & $0 \cdot 0115$ & 15 & $14 \cdot 6$ & $0 \cdot 22$ & $10 \cdot 0$ & $5 \cdot 2$ \\
\hline,,$\quad 15$ & $96 \cdot 0$ & $63 \cdot 0$ & $0 \cdot 011$ & 14 & $14 \cdot 2$ & $0 \cdot 23$ & $6 \cdot 5$ & $7 \cdot 5$ \\
\hline,$\quad 29$ & 98.5 & $49 \cdot 0$ & $0 \cdot 011$ & 14 & $15 \cdot 0$ & $0 \cdot 31$ & $2 \cdot 5$ & $13 \cdot 6$ \\
\hline Nov. 13 & $104 \cdot 0$ & $54 \cdot 0$ & $0 \cdot 011$ & 15 & $16 \cdot 7$ & $0 \cdot 31$ & $5 \cdot 5$ & $6 \cdot 8$ \\
\hline , $\quad 27$ & $105 \cdot 5$ & $43-$ & $0 \cdot 011$ & 14 & $16 \cdot 1$ & $0 \cdot 37+$ & $1 \cdot 5$ & $18 \cdot 0+$ \\
\hline
\end{tabular}

Cawsand, what is perhaps the best method of experimenting being employed, the arrangement at the outset of a graded series of fish such as has been described previously. It remains only to apply the results obtained to the estimation it is intended to make. By the use of the graphs shown in Figure 1 it is possible to read off the maintenance ratios of steadily-growing plaice from one fortnightly period to another, using the 
mid-kody weights for the periods concerned, and thus estimate approximately the quantity of food required for maintenance, which can then be expressed as a fraction of the total quantity of food taken.

Probably, the most useful estimate will be provided if the performances of plaice showing typical sigmoid growth-curves are made use of. The

\section{TABLE 69.}

\section{Data Concerning the Female Plaice B4 (1929).}

Showing growth in weight, food taken, and variation in maintenance ratio with increasing size. Also food quantities estimated as having been used for purpose of maintenance, fraction of total food and efficiency as regards food available for growth.

\begin{tabular}{|c|c|c|c|c|c|c|c|c|}
\hline $\begin{array}{c}\text { Date } \\
\text { (1929). }\end{array}$ & $\begin{array}{c}\text { Weight. } \\
\text { (gm.) }\end{array}$ & $\begin{array}{c}\text { Food } \\
\text { per } \\
\text { period. }\end{array}$ & $\begin{array}{l}\text { Main- } \\
\text { tenance } \\
\text { ratio } \\
\text { (from } \\
\text { Graph } \\
\text { Fig. 1). }\end{array}$ & $\begin{array}{c}\text { Days } \\
\text { in } \\
\text { period. }\end{array}$ & $\begin{array}{l}\text { Estimated } \\
\text { food } \\
\text { required } \\
\text { for main- } \\
\text { tenance } \\
\text { per period. } \\
\text { (gm.) }\end{array}$ & $\begin{array}{l}\text { Fraction of } \\
\text { total food } \\
\text { used for } \\
\text { mainten- } \\
\text { ance. }\end{array}$ & $\begin{array}{l} \\
\text { Growth } \\
\text { in } \\
\text { on weight } \\
\text { per } \\
\text { period. } \\
\text { (gm.) }\end{array}$ & $\begin{array}{c}\text { Efficiency } \\
\text { (gm. of } \\
\text { food re- } \\
\text { quired to } \\
\text { produce } \\
1 \cdot 0 \text { gm. } \\
\text { increase in } \\
\text { wt. of fish } \\
\text { allowing } \\
\text { for main- } \\
\text { tenance.) }\end{array}$ \\
\hline May 22 & $18 \cdot 5$ & - & - & - & - & - & - & - \\
\hline June 6 & $26 \cdot 0$ & $40 \cdot 0$ & $0 \cdot 0215$ & 15 & $7 \cdot 2$ & $0 \cdot 18$ & $7 \cdot 5$ & $4 \cdot 4$ \\
\hline ,, 20 & $32 \cdot 0$ & $22 \cdot 0$ & $0 \cdot 0185$ & 14 & $7 \cdot 5$ & $0 \cdot 34$ & $6 \cdot 0$ & $2 \cdot 4$ \\
\hline July 5 & $36 \cdot 5$ & $26 \cdot 0$ & $0 \cdot 017$ & 15 & $8 \cdot 7$ & $0 \cdot 33$ & $4 \cdot 5$ & $3 \cdot 8$ \\
\hline , $\quad 19$ & $43 \cdot 0$ & $36 \cdot 5$ & $0 \cdot 016$ & 14 & $8 \cdot 9$ & $0 \cdot 24$ & $6 \cdot 5$ & $4 \cdot 2$ \\
\hline Aug. 2 & $50 \cdot 5$ & $48 \cdot 7$ & $0 \cdot 015$ & 14 & $9 \cdot 8$ & $0 \cdot 20$ & $7 \cdot 5$ & $5 \cdot 2$ \\
\hline,$\quad 16$ & $60 \cdot 5$ & $51 \cdot 4$ & $0 \cdot 0135$ & 14 & $10 \cdot 5$ & $0 \cdot 20$ & $10 \cdot 0$ & $4 \cdot 1$ \\
\hline ,, 30 & $66 \cdot 0$ & $54 \cdot 3$ & $0 \cdot 013$ & 14 & $10 \cdot 9$ & $0 \cdot 20$ & $5 \cdot 5$ & $7 \cdot 9$ \\
\hline Sept. 16 & $76 \cdot 0$ & $65 \cdot 5$ & $0 \cdot 0125$ & 17 & $15 \cdot 1$ & $0 \cdot 23$ & $10 \cdot 0$ & $5 \cdot 0$ \\
\hline Oct. 1 & $83 \cdot 5$ & $55 \cdot 2$ & $0 \cdot 012$ & 15 & $14 \cdot 4$ & $0 \cdot 26$ & $7 \cdot 5$ & $5 \cdot 3$ \\
\hline,$\quad 15$ & $90 \cdot 0$ & $59 \cdot 0$ & 0.0115 & 14 & $14 \cdot 0$ & $0 \cdot 24$ & $6 \cdot 5$ & $6 \cdot 9$ \\
\hline , $\quad 29$ & $102 \cdot 0$ & $63 \cdot 0$ & $0 \cdot 011$ & 14 & $14 \cdot 8$ & $0 \cdot 23$ & $12 \cdot 0$ & $4 \cdot 0$ \\
\hline Nov. 13 & $108 \cdot 0$ & $52 \cdot 5$ & $0 \cdot 011$ & 15 & $17 \cdot 2$ & $0 \cdot 34$ & $6 \cdot 0$ & $5 \cdot 9$ \\
\hline,,$\quad 27$ & $103 \cdot 5$ & $38 \cdot 5$ & $0 \cdot 011$ & 14 & $16 \cdot 3$ & $0 \cdot 42$ & $4 \cdot 5$ & - \\
\hline
\end{tabular}

growth performances during 1930 are apparently subnormal, those of 1928 are marred by the possibility of food leakages. Undoubtedly the results obtained in the experiments with the male D3 and the females B1 and B4 are likely to be of most use in this respect. Accordingly these will be employed.

In Table 67, which is partly derived from data shown in Table 20 of 
my previous paper, are shown the weights of D3 on a succession of weighing days from June 6th to November 28th, 1929. The maintenance ratios, obtained from the graph in Figure 1, are shown in col. 4, while in col. 6 is shown the estimated maintenance requirements for the periods, these being given as fractions of the total food in col. 7. It is seen that for the period ending June $20 \mathrm{th}, 6 \cdot 0 \mathrm{gm}$., or $0 \cdot 27$ of the total food taken, was required for maintenance and that for the period ending October 29th, $16 \cdot 2 \mathrm{gm}$., or $0 \cdot 26$ of the total, was required. From June 6 th to October

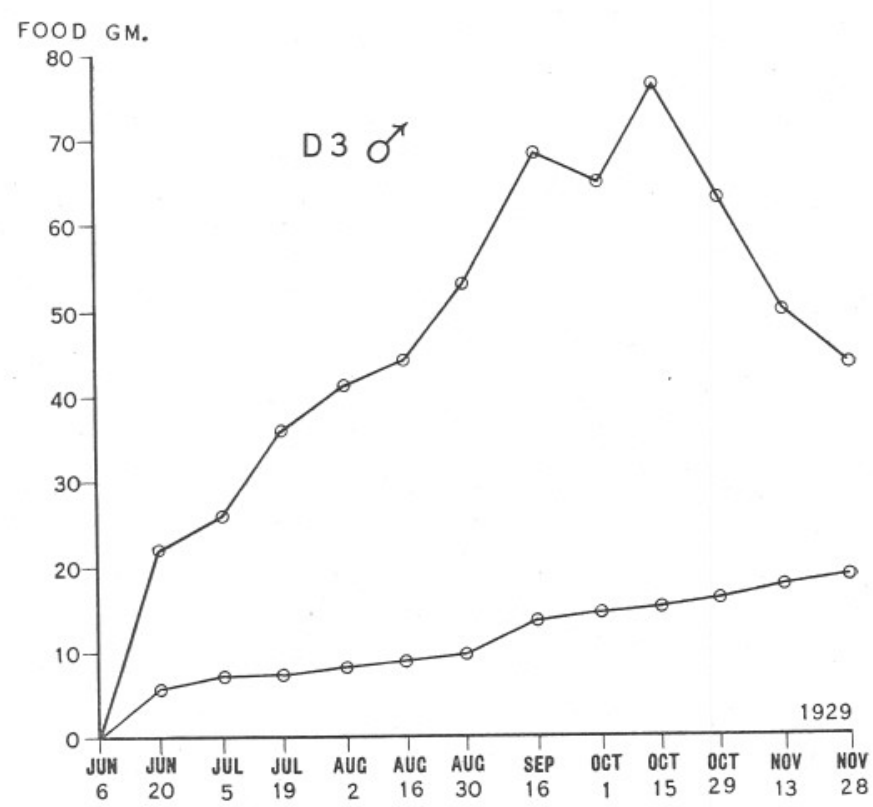

FIa. 10.-Acceleration curves showing the relationship between the total quantity of food taken by D3 $\left(\sigma^{\hat{*}}\right)$ during 1929 and the quantities estimated as having been used for purposes of maintenance. Above, total food; below, food for maintenance.

29 th the fraction for the various fortnightly periods varied between $0 \cdot 18$ and $0 \cdot 28$. These results are shown graphically in Figure 10. During November, when feeding was becoming inhibited, the fraction was increased, but the figures quoted do not take into consideration the slight fall in value of the maintenance ratio which would undoubtedly occur here. For the whole of the experiment, 177 days, the total food taken was $585 \mathrm{gm}$. of which, according to this estimate, $145 \mathrm{gm}$. have been required to satisfy basal requirements, i.e. approximately 25 per cent of the total. In the last column of Table 67 are shown indices of efficiency relating to food available for the promotion of growth, and it is seen that these vary 
from period to period up till the end of October between $3 \cdot 7$ and $9 \cdot 4$. Thus, no matter whether efficiency is estimated in terms of total food or in terms of food available for growth, the efficiency index is not constant for successive short periods during the growth season. But the table indicates that the index is, in round numbers, 4 during each of six periods and greater than 4 during six others. It appears that of food available for growth purposes every $4 \mathrm{gm}$. generally produces $1.0 \mathrm{gm}$. of fish.

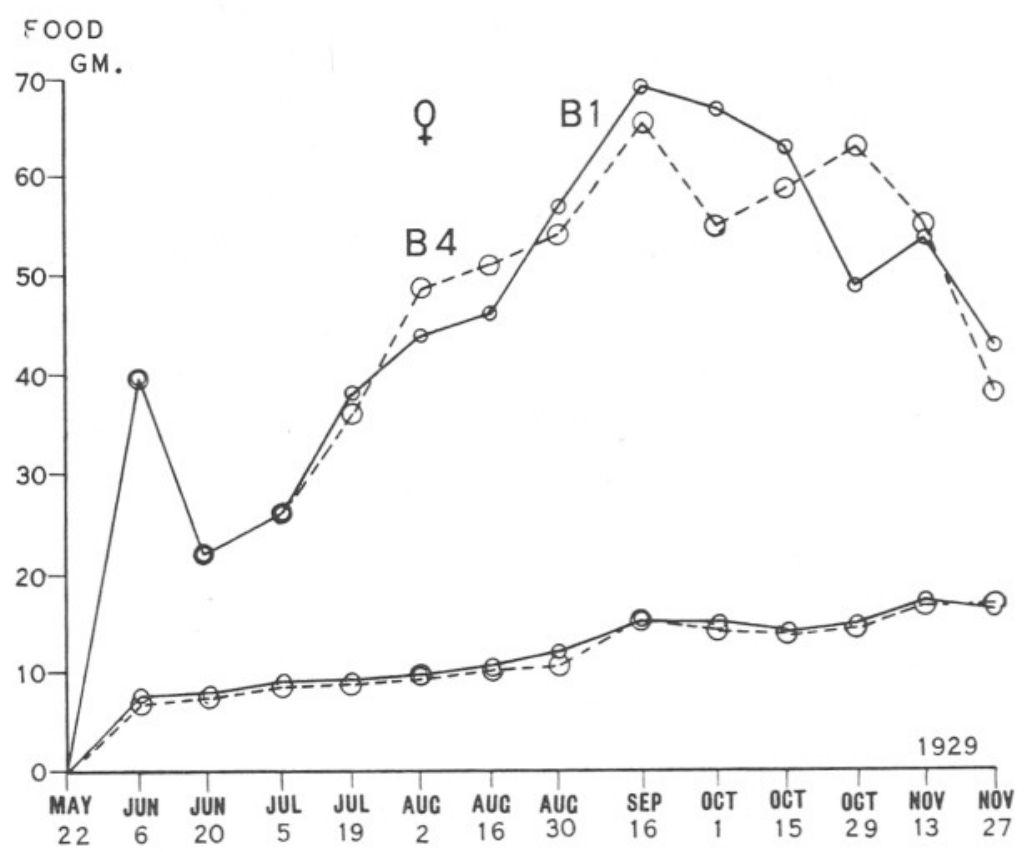

FIG. 11.-Acceleration eurves showing the relationship between the total quantities of food taken by B1 and B4 ( $\nsucceq)$ during 1929 and the quantities estimated as having been used for purposes of maintenance. Above, total food: below, food for maintenance.

Tables 68 and 69 present data for the females B1 and B4, the method of obtaining them being precisely the same as that used for D3. For the period of 15 days ending June $6 \mathrm{th}, \mathrm{B} 1$ required $7.8 \mathrm{gm}$. of food for maintenance, $0 \cdot 20$ of the total quantity taken, while for the period of 14 days ending October 29 th it required $15.0 \mathrm{gm}$. or 0.31 of the total quantity taken (Table 68). For the whole experiment, 189 days, $618 \mathrm{gm}$. of food was taken, of which $158 \mathrm{gm}$. is estimated as having been required for maintenance, i.e. approximately 25 per cent of the total. These results are shown graphically in Figure 11. In the case of B4 $7 \cdot 2 \mathrm{gm}$. of food or $0 \cdot 18$ of the total quantity taken was required for maintenance during 15 days to June 6 th, $14 \cdot 8 \mathrm{gm}$. or $0 \cdot 23$ of the total during 14 days to October 
29th. During 187 days a total of $613 \mathrm{gm}$. of food was taken, of which $155 \mathrm{gm}$. was used for purposes of maintenance, again approximately 25 per cent of the total (Table 69). It is seen that the efficiency as regards food available for growth was just as inconstant as in the cases of B1 and D3. But for five periods the efficiency index was, in round numbers, 4, and for three periods 5, from which it can be inferred that generally between 4 and $5 \mathrm{gm}$. of food available for growth produce $1.0 \mathrm{gm}$. of fish. For B1 it appears that $5 \mathrm{gm}$. was required to produce this weight of fish, the efficiency shown being slightly less than that shown by B4. For the whole experiment the average efficiencies read as follows : $\mathrm{B} 1-5 \cdot 4$, B4$4 \cdot 9$, and D $3-4 \cdot 8$, the male thus showing the greatest degree of efficiency.

The general conclusions afforded by these estimates are uniform for males and females alike. Of the total food taken during the growth season, approximately 25 per cent is used for maintenance. Of the remainder which is available for the promotion of growth, on the average for the season and expressed in round numbers each $5 \mathrm{gm}$. produces $1.0 \mathrm{gm}$. increase in weight of the fish, although for shorter periods $4 \mathrm{gm}$., or even slightly less, may produce such an increase.

The discussion part of this paper must serve as a summary of results, since to summarise further would scarcely serve a useful purpose. In many respects it is considered that the treatment of the available data by the methods adopted is scarcely adequate, and it is hoped to be able to treat these data by strictly statistical methods in the near future. When the methods of correlation are applied to the data, it is likely that reliable generalised results will be forthcoming which might possibly have a greater practical application in fishery research.

\section{ACKNowledgement.}

I wish to record my cordial thanks to Dr. E. J. Allen who in very many ways has helped to meet the difficulties that have arisen during the course of this work and who by consistent kindness has caused very tedious work to seem much less tedious, for which I am very grateful. Dr. E. S. Russell and Mr. T. Edser have been ever ready to help with suggestions and criticism and to them also is recorded a mark of my appreciation. Thanks are also due to Mr. H. Lees for the care he has shown in his charge of the Lympstone experiments under the direction of Dr. Russell and Mr. Edser, and to all members of the stafi of the Marine Biological Association who have assisted in the work. Mr. Seale and the captain and crew of the Salpa have also rendered valuable service and to them also my thanks are tendered. 
TABLES $1-6$.

Data Obtained from the Experiments on the Maintenance Requirements of Male Plaice.

TaBle 1: C1.

\begin{tabular}{|c|c|c|c|c|c|c|c|c|c|c|c|c|}
\hline \multirow{2}{*}{$\begin{array}{c}\text { Date } \\
\text { (1930) }\end{array}$} & \multicolumn{2}{|c|}{$\begin{array}{c}\text { Size } \\
\text { of flsh. }\end{array}$} & \multicolumn{2}{|c|}{$\begin{array}{l}\text { Growth } \\
\text { per } \\
\text { period. }\end{array}$} & \multirow{2}{*}{$\begin{array}{l}\text { Weight } \\
\text { of food } \\
\text { per } \\
\text { period. } \\
\text { (gm.) }\end{array}$} & \multirow[t]{2}{*}{$\begin{array}{c}\text { No. of } \\
\text { days } \\
\text { in } \\
\text { period. }\end{array}$} & \multirow{2}{*}{$\begin{array}{c}\text { Average } \\
\text { weight } \\
\text { of food } \\
\text { per day. } \\
\text { (gm.) }\end{array}$} & \multirow{2}{*}{$\begin{array}{l}\text { Ratio of } \\
\text { food per } \\
\text { day/ } \\
\text { /average } \\
\text { body-wt. } \\
\text { for } \\
\text { period. }\end{array}$} & \multirow{2}{*}{$\begin{array}{l}\text { Total } \\
\text { wt. of } \\
\text { food } \\
\text { to date. } \\
\text { (gm.) }\end{array}$} & \multirow{2}{*}{$\begin{array}{l}\text { No. of } \\
\text { days } \\
\text { since } \\
\text { com- } \\
\text { mence- } \\
\text { ment of } \\
\text { expt. }\end{array}$} & \multicolumn{2}{|c|}{$\begin{array}{l}\text { Cumulative } \\
\text { growth. }\end{array}$} \\
\hline & $\begin{array}{l}\text { Lth. } \\
\text { (em.) }\end{array}$ & $\begin{array}{c}\text { Wt. } \\
\text { (gm.) }\end{array}$ & $\begin{array}{l}\text { Lth. } \\
\text { (cm.) }\end{array}$ & $\underset{\text { (gt.) }}{\text { Wt. }}$ & & & & & & & $\begin{array}{l}\text { Lth. } \\
\text { (cm.) }\end{array}$ & $\begin{array}{l}\text { Wt. } \\
\text { (gm.) }\end{array}$ \\
\hline May 14 & $13 \cdot 1$ & $21 \cdot 5$ & - & - & - & - & - & - & - & - & - & - \\
\hline , 26 & $13 \cdot 0$ & $20 \cdot 5$ & $-0 \cdot 1$ & $-1 \cdot 0$ & $4 \cdot 2$ & 12 & $0 \cdot 35$ & 0.017 & $4 \cdot 5$ & 12 & -0.1 & $-1 \cdot 0$ \\
\hline June 9 & $13 \cdot 0$ & $19 \cdot 3$ & nil & $-1 \cdot 2$ & $3 \cdot 4$ & 14 & $0 \cdot 24$ & 0.012 & $7 \cdot 9$ & 26 & -0.1 & $-2 \cdot 2$ \\
\hline,,$\quad 23$ & $13 \cdot 0$ & $17 \cdot 8$ & nil & $-1 \cdot 5$ & $3 \cdot 4$ & 14 & $0 \cdot 24$ & 0.013 & $11 \cdot 3$ & 40 & -0.1 & $-3 \cdot 7$ \\
\hline July 7 & $13 \cdot 0$ & $19 \cdot 3$ & nil & $1 \cdot 5$ & $8 \cdot 5$ & 14 & $0 \cdot 61$ & $0 \cdot 031$ & $19 \cdot 8$ & 54 & -0.1 & $-2 \cdot 2$ \\
\hline,$\quad 21$ & $13 \cdot 1$ & $20 \cdot 0$ & $0 \cdot 1$ & $0 \cdot 7$ & $7 \cdot 1$ & 14 & 0.51 & 0.026 & $26 \cdot 9$ & 68 & nil & $-1 \cdot 5$ \\
\hline Aug. 6 & $13 \cdot 3$ & $21 \cdot 0$ & $0 \cdot 2$ & $1 \cdot 0$ & $8 \cdot 0$ & 16 & 0.50 & 0.024 & $34 \cdot 9$ & 84 & $0 \cdot 2$ & -0.5 \\
\hline,$\quad 21$ & $13 \cdot 3$ & $21 \cdot 5$ & nil & 0.5 & $7 \cdot 5$ & 15 & $0 \cdot 50$ & $0 \cdot 024$ & $42 \cdot 4$ & 99 & $0 \cdot 2$ & nil \\
\hline Sept. 5 & $13 \cdot 3$ & $20 \cdot 7$ & nil & -0.8 & $6 \cdot 0$ & 15 & 0.40 & $0 \cdot 019$ & $48 \cdot 4$ & 114 & $0 \cdot 2$ & -0.8 \\
\hline , 19 & $13 \cdot 3$ & $20 \cdot 7$ & nil & nil & $8 \cdot 5$ & 14 & $0 \cdot 61$ & $0 \cdot 030$ & $56 \cdot 9$ & 128 & $0 \cdot 2$ & $-0 \cdot 8$ \\
\hline Oct. 5 & $13 \cdot 4$ & $20 \cdot 8$ & $0 \cdot 1$ & $0 \cdot 1$ & $10 \cdot 0$ & 16 & 0.62 & 0.030 & $66 \cdot 9$ & 144 & $0 \cdot 3$ & -0.7 \\
\hline
\end{tabular}

TABle 2: C2.

\begin{tabular}{|c|c|c|c|c|c|c|c|c|c|c|c|c|}
\hline May 14 & $15 \cdot 3$ & $31 \cdot 5$ & - & - & - & - & - & - & - & - & - & - \\
\hline,$\quad 26$ & $15 \cdot 3$ & $31 \cdot 6$ & nil & $0 \cdot 1$ & $7 \cdot 8$ & 12 & $0 \cdot 65$ & 0.021 & $7 \cdot 8$ & 12 & nil & $0 \cdot 1$ \\
\hline June 9 & $15 \cdot 4$ & $32 \cdot 5$ & $0 \cdot 1$ & 0.9 & $6 \cdot 9$ & 14 & $0 \cdot 49$ & 0.015 & $14 \cdot 7$ & 26 & $0 \cdot 1$ & 1.0 \\
\hline,,$\quad 23$ & $15 \cdot 5$ & $32 \cdot 3$ & $0 \cdot 1$ & -0.2 & $6 \cdot 4$ & 14 & 0.46 & 0.014 & $21 \cdot 1$ & 40 & 0.2 & 0.8 \\
\hline July 7 & $15 \cdot 6$ & $33 \cdot 2$ & $0 \cdot 1$ & 0.9 & $7 \cdot 0$ & 14 & 0.50 & 0.015 & $28 \cdot 1$ & 54 & $0 \cdot 3$ & $1 \cdot 7$ \\
\hline,,$\quad 21$ & $15 \cdot 8$ & $34 \cdot 0$ & $0 \cdot 2$ & $0 \cdot 8$ & $6 \cdot 6$ & 14 & $0 \cdot 47$ & 0.014 & $34 \cdot 7$ & 68 & $0 \cdot 5$ & $2 \cdot 5$ \\
\hline Aug. 6 & $15 \cdot 9$ & $35 \cdot 0$ & $0 \cdot 1$ & $1 \cdot 0$ & $7 \cdot 5$ & 16 & $0 \cdot 47$ & 0.014 & $42 \cdot 2$ & 84 & 0.6 & $3 \cdot 5$ \\
\hline,$\quad 21$ & $15 \cdot 9$ & $35 \cdot 2$ & nil & $0 \cdot 2$ & $7 \cdot 4$ & 15 & $0 \cdot 49$ & $0 \cdot 014$ & $49 \cdot 6$ & 99 & 0.6 & $3 \cdot 7$ \\
\hline Sept. 5 & $16 \cdot 0$ & $35 \cdot 0$ & $0 \cdot 1$ & $-0 \cdot 2$ & $7 \cdot 0$ & 15 & $0 \cdot 47$ & $0 \cdot 013$ & $56 \cdot 6$ & 114 & $0 \cdot 7$ & $3 \cdot 5$ \\
\hline,$\quad 19$ & $16 \cdot 0$ & $35 \cdot 4$ & nil & $0 \cdot 4$ & $7 \cdot 0$ & 14 & $0 \cdot 45$ & $0 \cdot 013$ & $63 \cdot 6$ & 128 & $0 \cdot 7$ & $3 \cdot 9$ \\
\hline Oct. 6 & $16 \cdot 1$ & $36 \cdot 5$ & 0.1 & $1 \cdot 1$ & $8 \cdot 5$ & 17 & $0 \cdot 50$ & $0 \cdot 014$ & $72 \cdot 1$ & 145 & $0 \cdot 8$ & $5 \cdot 0$ \\
\hline,,$\quad 22$ & $16 \cdot 1$ & $36 \cdot 8$ & nil & $0 \cdot 3$ & $5 \cdot 8$ & 16 & $0 \cdot 41$ & 0.011 & $77 \cdot 9$ & 161 & $0 \cdot 8$ & $5 \cdot 3$ \\
\hline Nov. 6 & $16 \cdot 2$ & $35 \cdot 9$ & $0 \cdot 1$ & $-0 \cdot 9$ & $6 \cdot 0$ & 15 & $0 \cdot 40$ & $0 \cdot 011$ & $83 \cdot 9$ & 176 & $0 \cdot 9$ & $4 \cdot 4$ \\
\hline
\end{tabular}

Table 3: C3.

\begin{tabular}{|c|c|c|c|c|c|c|c|c|c|c|c|c|}
\hline May 28 & $16 \cdot 9$ & $45 \cdot 0$ & - & 一 & - & - & - & - & - & - & - & - \\
\hline June 9 & $17 \cdot 0$ & $46 \cdot 5$ & $0 \cdot 1$ & $1 \cdot 5$ & $9 \cdot 3$ & 12 & $0 \cdot 77$ & 0.016 & $9 \cdot 3$ & 12 & $0 \cdot 1$ & $1 \cdot 5$ \\
\hline,$\quad 23$ & $17 \cdot 2$ & $46 \cdot 5$ & 0.2 & nil & $8 \cdot 0$ & 14 & 0.57 & 0.012 & $17 \cdot 3$ & 26 & 0.3 & $1 \cdot 5$ \\
\hline July 7 & $17 \cdot 3$ & $48 \cdot 4$ & $0 \cdot 1$ & $1 \cdot 9$ & $8 \cdot 0$ & 14 & 0.57 & 0.012 & $25 \cdot 3$ & 40 & 0.4 & $3 \cdot 4$ \\
\hline ,, 21 & $17 \cdot 4$ & $48 \cdot 5$ & 0.1 & $0 \cdot 1$ & $7 \cdot 6$ & 14 & $0 \cdot 54$ & 0.011 & $32 \cdot 9$ & 54 & 0.5 & $3 \cdot 5$ \\
\hline Aug. $\quad 6$ & $17 \cdot 4$ & $46 \cdot 0$ & nil & $-2 \cdot 5$ & $8 \cdot 2$ & 16 & 0.51 & 0.011 & $41 \cdot 1$ & 70 & $0 \cdot 5$ & $1 \cdot 0$ \\
\hline,$\quad 21$ & $17 \cdot 3$ & $44 \cdot 8$ & -0.1 & $-1 \cdot 2$ & $8 \cdot 0$ & 15 & 0.53 & 0.012 & $49 \cdot 1$ & 85 & $0 \cdot 4$ & $-0 \cdot 2$ \\
\hline Sept. 5 & $17 \cdot 2$ & $42 \cdot 9$ & $-0 \cdot 1$ & $-1 \cdot 9$ & $8 \cdot 0$ & 15 & $0 \cdot 53$ & 0.012 & $57 \cdot 1$ & 100 & $0 \cdot 3$ & $-2 \cdot 1$ \\
\hline 19 & $17 \cdot 4$ & $42 \cdot 7$ & $0 \cdot 2$ & $-0 \cdot 2$ & $11 \cdot 5$ & 14 & $0 \cdot 82$ & $0 \cdot 019$ & $68 \cdot 6$ & 114 & 0.5 & $-2 \cdot 3$ \\
\hline Oct. $\quad 6$ & $17 \cdot 4$ & $44 \cdot 1$ & nil & $1 \cdot 4$ & $14 \cdot 0$ & 17 & $0 \cdot 81$ & 0.019 & $82 \cdot 6$ & 131 & $0 \cdot 5$ & -0.9 \\
\hline,$\quad 22$ & $17 \cdot 4$ & $44 \cdot 1$ & nil & nil & $10 \cdot 8$ & 16 & $0 \cdot 67$ & 0.015 & $93 \cdot 4$ & 147 & $0 \cdot 5$ & -0.9 \\
\hline Nov. 6 & $17 \cdot 4$ & $43 \cdot 0$ & nil & $-1 \cdot 1$ & $10 \cdot 3$ & 15 & $0 \cdot 70$ & 0.016 & $103 \cdot 7$ & 162 & $0 \cdot 5$ & $-2 \cdot 0$ \\
\hline
\end{tabular}


Table 4: C4.

\begin{tabular}{|c|c|c|c|c|c|c|c|c|c|c|c|c|}
\hline \multirow{2}{*}{$\begin{array}{l}\text { Date } \\
\{1930\}\end{array}$} & \multicolumn{2}{|c|}{$\begin{array}{c}\text { Size } \\
\text { of flsh. }\end{array}$} & \multicolumn{2}{|c|}{$\begin{array}{l}\text { Growth } \\
\text { per } \\
\text { period. }\end{array}$} & \multirow{2}{*}{$\begin{array}{l}\text { Weight } \\
\text { of food } \\
\text { per } \\
\text { period. } \\
\text { (gm.) }\end{array}$} & \multirow[t]{2}{*}{$\begin{array}{c}\text { No. of } \\
\text { days } \\
\text { in } \\
\text { period. }\end{array}$} & \multirow{2}{*}{$\begin{array}{l}\text { Average } \\
\text { weight } \\
\text { of food } \\
\text { per day. } \\
\text { (gm.) }\end{array}$} & \multirow{2}{*}{$\begin{array}{l}\text { Ratio of } \\
\text { food per } \\
\text { day/ } \\
\text { /average } \\
\text { body-wt. } \\
\text { for } \\
\text { period. }\end{array}$} & \multirow{2}{*}{$\begin{array}{c}\text { Total } \\
\text { wt. of } \\
\text { food } \\
\text { to date. } \\
\text { (gm.) }\end{array}$} & \multirow{2}{*}{$\begin{array}{l}\text { No. of } \\
\text { days } \\
\text { since } \\
\text { com- } \\
\text { mence- } \\
\text { ment of } \\
\text { expt. }\end{array}$} & \multicolumn{2}{|c|}{$\begin{array}{l}\text { Cumulative } \\
\text { growth. }\end{array}$} \\
\hline & $\begin{array}{l}\text { Lth. } \\
\text { (em.) }\end{array}$ & $\begin{array}{l}\text { Wt. } \\
\text { (gm.) }\end{array}$ & $\begin{array}{l}\text { Lth. } \\
\text { (em.) }\end{array}$ & $\begin{array}{l}\text { Wt. } \\
\text { (gm.) }\end{array}$ & & & & & & & $\begin{array}{l}\text { Lth. } \\
\text { (em.) }\end{array}$ & $\begin{array}{l}\text { Wt. } \\
\text { (gm.) }\end{array}$ \\
\hline May 12 & $18 \cdot 9$ & $59 \cdot 0$ & - & - & - & - & - & - & - & - & - & - \\
\hline,,$\quad 26$ & $18 \cdot 9$ & $61 \cdot 0$ & nil & $2 \cdot 0$ & $11 \cdot 3$ & 14 & $0 \cdot 81$ & 0.013 & $11 \cdot 3$ & 14 & nil & $2 \cdot 0$ \\
\hline June 9 & $19 \cdot 0$ & $59 \cdot 6$ & 0.1 & $-1 \cdot 4$ & $11 \cdot 9$ & 14 & 0.85 & $0 \cdot 014$ & $23 \cdot 2$ & 28 & $0 \cdot 1$ & $0 \cdot 6$ \\
\hline,,$\quad 23$ & $19 \cdot 0$ & $61 \cdot 0$ & nil & $1 \cdot 4$ & $14 \cdot 0$ & 14 & 1.00 & 0.017 & $37 \cdot 2$ & 42 & $0 \cdot 1$ & $2 \cdot 0$ \\
\hline July 7 & $19 \cdot 0$ & $61 \cdot 2$ & nil & $0 \cdot 2$ & $13 \cdot 0$ & 14 & 0.93 & 0.015 & $50 \cdot 2$ & 56 & $0 \cdot 1$ & $2 \cdot 2$ \\
\hline,,$\quad 21$ & $19 \cdot 1$ & $63 \cdot 0$ & $0 \cdot 1$ & $1 \cdot 8$ & $12 \cdot 1$ & 14 & $0 \cdot 86$ & 0.014 & $62 \cdot 3$ & 70 & $0 \cdot 2$ & $4 \cdot 0$ \\
\hline Aug. 6 & $19 \cdot 2$ & $62 \cdot 2$ & 0.1 & -0.8 & $12 \cdot 4$ & 16 & $0 \cdot 77$ & 0.012 & $74 \cdot 7$ & 86 & $0 \cdot 3$ & $3 \cdot 2$ \\
\hline , 21 & $19 \cdot 2$ & $61 \cdot 0$ & nil & $-1 \cdot 2$ & $12 \cdot 5$ & 15 & $0 \cdot 83$ & 0.013 & $87 \cdot 2$ & 101 & $0 \cdot 3$ & $2 \cdot 0$ \\
\hline Sept. 5 & $19 \cdot 2$ & $60 \cdot 1$ & nil & -0.9 & $12 \cdot 0$ & 15 & $0 \cdot 80$ & 0.013 & $99 \cdot 2$ & 116 & $0 \cdot 3$ & $1 \cdot 1$ \\
\hline ,, 19 & $19 \cdot 2$ & $61 \cdot 8$ & nil & $1 \cdot 7$ & $17 \cdot 5$ & 14 & $1 \cdot 25$ & $0 \cdot 020$ & $116 \cdot 7$ & 130 & $0 \cdot 3$ & $2 \cdot 8$ \\
\hline Oct. $\quad 6$ & $19 \cdot 3$ & $62 \cdot 8$ & $0 \cdot 1$ & $1 \cdot 0$ & $18 \cdot 5$ & 17 & $1 \cdot 09$ & 0.016 & $135 \cdot 2$ & 147 & $0 \cdot 4$ & $3 \cdot 8$ \\
\hline,,$\quad 22$ & $19 \cdot 4$ & $62 \cdot 8$ & $0 \cdot 1$ & nil & $15 \cdot 0$ & 16 & $0 \cdot 94$ & 0.015 & $150 \cdot 2$ & 163 & $0 \cdot 5$ & $3 \cdot 8$ \\
\hline Nov. 6 & $19 \cdot 3$ & $62 \cdot 5$ & $-0 \cdot 1$ & $-0 \cdot 3$ & $7 \cdot 5$ & 15 & 0.50 & 0.008 & $157 \cdot 7$ & 178 & $0 \cdot 4$ & $3 \cdot 5$ \\
\hline
\end{tabular}

Table 5: C5.

\begin{tabular}{|c|c|c|c|c|c|c|c|c|c|c|c|c|}
\hline May 26 & $21 \cdot 2$ & $86 \cdot 7$ & - & - & - & - & - & - & - & - & - & - \\
\hline June 9 & $21 \cdot 3$ & $86 \cdot 5$ & $0 \cdot 1$ & $-0 \cdot 2$ & $13 \cdot 8$ & 14 & 0.99 & 0.011 & $13 \cdot 8$ & 14 & $0 \cdot 1$ & -0.2 \\
\hline,$\quad 23$ & $21 \cdot 4$ & $87 \cdot 5$ & $0 \cdot 1$ & $1 \cdot 0$ & $13 \cdot 8$ & 14 & 0.99 & 0.011 & $27 \cdot 6$ & 28 & $0 \cdot 2$ & 0.8 \\
\hline July 7 & $21 \cdot 4$ & $88 \cdot 2$ & nil & 0.7 & $13 \cdot 0$ & 14 & 0.93 & 0.011 & $40 \cdot 6$ & 42 & $0 \cdot 2$ & $1 \cdot 5$ \\
\hline ,, 21 & $21 \cdot 4$ & $89 \cdot 0$ & nil & $0 \cdot 8$ & $12 \cdot 3$ & 14 & $0 \cdot 88$ & 0.010 & $52 \cdot 9$ & 56 & $0 \cdot 2$ & $2 \cdot 3$ \\
\hline Aug. 6 & $21 \cdot 4$ & $86 \cdot 5$ & nil & $-2 \cdot 5$ & $13 \cdot 4$ & 16 & $0 \cdot 84$ & 0.010 & $66 \cdot 3$ & 72 & $0 \cdot 2$ & -0.2 \\
\hline,$\quad 21$ & $21 \cdot 4$ & $87 \cdot 2$ & nil & $0 \cdot 7$ & $13 \cdot 5$ & 15 & $0 \cdot 90$ & 0.010 & $79 \cdot 8$ & 87 & $0 \cdot 2$ & 0.5 \\
\hline Sept. 5 & $21 \cdot 5$ & $85 \cdot 2$ & $0 \cdot 1$ & $-2 \cdot 0$ & $13 \cdot 0$ & 15 & $0 \cdot 87$ & 0.010 & $92 \cdot 8$ & 102 & $0 \cdot 3$ & $-1 \cdot 5$ \\
\hline,$\quad 19$ & $21 \cdot 4$ & $84 \cdot 3$ & $-0 \cdot 1$ & -0.9 & $15 \cdot 5$ & 14 & $1 \cdot 11$ & $0 \cdot 013$ & $108 \cdot 3$ & 116 & $0 \cdot 2$ & $-2 \cdot 4$ \\
\hline Oct. 6 & $21 \cdot 5$ & $85 \cdot 6$ & $0 \cdot 1$ & $1 \cdot 3$ & $19 \cdot 0$ & 17 & $1 \cdot 12$ & $0 \cdot 013$ & $127 \cdot 3$ & 133 & $0 \cdot 3$ & $-1 \cdot 1$ \\
\hline , 22 & $21 \cdot 5$ & $85 \cdot 6$ & nil & nil & $16 \cdot 0$ & 16 & $1 \cdot 00$ & 0.012 & $143 \cdot 3$ & 149 & $0 \cdot 3$ & $-1 \cdot 1$ \\
\hline Nov. & & 85.4 & nil & 0.9 & & & $0 \cdot 87$ & 0.010 & $156 \cdot 3$ & 164 & $0 \cdot 3$ & $-1 \cdot 3$ \\
\hline
\end{tabular}

Table 6: C6.

\begin{tabular}{|c|c|c|c|c|c|c|c|c|c|c|c|c|}
\hline June 12 & $23 \cdot 0$ & $115 \cdot 0$ & - & - & - & - & - & - & - & - & - & \\
\hline,$\quad 23$ & $23 \cdot 0$ & $113 \cdot 0$ & nil & $-2 \cdot 0$ & $14 \cdot 7$ & 11 & $1 \cdot 34$ & 0.012 & $14 \cdot 7$ & 11 & nil & $-2 \cdot 0$ \\
\hline July 7 & $23 \cdot 0$ & $112 \cdot 8$ & nil & $-0 \cdot 2$ & $19 \cdot 5$ & 14 & $1 \cdot 39$ & 0.012 & $34 \cdot 2$ & 25 & nil & $-2 \cdot 2$ \\
\hline,$\quad 21$ & $22 \cdot 8$ & $115 \cdot 0$ & $-0 \cdot 2$ & $2 \cdot 2$ & $19 \cdot 8$ & 14 & $1 \cdot 41$ & 0.012 & $54 \cdot 0$ & 39 & -0.2 & nil \\
\hline Aug. $\quad 6$ & $22 \cdot 7$ & $113 \cdot 2$ & $-0 \cdot 1$ & $-1 \cdot 8$ & $19 \cdot 8$ & 16 & $1 \cdot 24$ & 0.011 & $73 \cdot 8$ & 55 & $-0 \cdot 3$ & $-1 \cdot 8$ \\
\hline , $\quad 21$ & $22 \cdot 8$ & $113 \cdot 2$ & $0 \cdot 1$ & nil & $19 \cdot 0$ & 15 & $1 \cdot 27$ & $0 \cdot 011$ & $92 \cdot 8$ & 70 & $-0 \cdot 2$ & $-1 \cdot 8$ \\
\hline Sept. 5 & $22 \cdot 7$ & $110 \cdot 0$ & $-0 \cdot 1$ & $-3 \cdot 2$ & $18 \cdot 5$ & 15 & $1 \cdot 23$ & 0.011 & $111 \cdot 3$ & 85 & $-0 \cdot 3$ & $-5 \cdot 0$ \\
\hline,$\quad 19$ & $22 \cdot 8$ & $109 \cdot 5$ & $0 \cdot 1$ & -0.5 & $25 \cdot 0$ & 14 & $1 \cdot 79$ & $0 \cdot 016$ & $136 \cdot 3$ & 99 & -0.2 & $-5 \cdot 5$ \\
\hline Oct. 6 & $22 \cdot 7$ & $109 \cdot 8$ & $-0 \cdot 1$ & $0 \cdot 3$ & $27 \cdot 7$ & 17 & $1 \cdot 63$ & 0.015 & $164 \cdot 0$ & 116 & $-0 \cdot 3$ & $-5 \cdot 2$ \\
\hline,$\quad 22$ & $22 \cdot 8$ & $112 \cdot 5$ & $0 \cdot 1$ & $2 \cdot 7$ & $25 \cdot 2$ & 16 & 1.57 & $0 \cdot 014$ & $189 \cdot 2$ & 132 & -0.2 & $-2 \cdot 5$ \\
\hline Nov. 6 & $22 \cdot 8$ & $111 \cdot 1$ & nil & -1.4 & $19 \cdot 3$ & 15 & $1 \cdot 29$ & 0.012 & $208 \cdot 5$ & 147 & -0.2 & $-3 \cdot 9$ \\
\hline
\end{tabular}


TABLE 7 .

Summarised Data Concerning the Maintenance Requirements of the Male Plaice, C1-C6.

\begin{tabular}{|c|c|c|c|c|c|c|c|c|c|}
\hline \multirow[b]{2}{*}{$\begin{array}{l}\text { Fish } \\
\text { No. }\end{array}$} & \multicolumn{2}{|c|}{$\begin{array}{c}\text { Initial } \\
\text { size. }\end{array}$} & \multicolumn{2}{|c|}{$\begin{array}{c}\text { Final } \\
\text { size. }\end{array}$} & \multicolumn{2}{|c|}{ Growth. } & \multirow[b]{2}{*}{$\begin{array}{c}\text { Days } \\
\text { in } \\
\text { period. }\end{array}$} & \multirow{2}{*}{$\begin{array}{c}\text { Average } \\
\text { weight } \\
\text { of food } \\
\text { per day. } \\
\text { (gm.) }\end{array}$} & \multirow{2}{*}{$\begin{array}{c}\text { Ratio } \\
\text { Food per } \\
\text { day// } \\
/ \text { mid } \\
\text { body- } \\
\text { weight } \\
\text { per period. }\end{array}$} \\
\hline & $\begin{array}{l}\text { Lth. } \\
\mathrm{cm} .\end{array}$ & $\begin{array}{l}\text { Wt. } \\
\text { gm. }\end{array}$ & $\begin{array}{l}\text { Lth. } \\
\mathrm{cm} .\end{array}$ & $\begin{array}{l}\text { Wt. } \\
\text { gm. }\end{array}$ & $\begin{array}{l}\text { Lth. } \\
\mathrm{cm} .\end{array}$ & $\begin{array}{l}\text { Wt. } \\
\text { gm. }\end{array}$ & & & \\
\hline C1 & $13 \cdot 1$ & $21 \cdot 5$ & $13 \cdot 4$ & $20 \cdot 8$ & $0 \cdot 3$ & $-0 \cdot 7$ & 144 & $0 \cdot 46$ & 0.022 \\
\hline $\mathrm{C} 2$ & $15 \cdot 3$ & $31 \cdot 5$ & $16 \cdot 2$ & $35 \cdot 9$ & $0 \cdot 9$ & $4 \cdot 4$ & 176 & $0 \cdot 49$ & $0 \cdot 015$ \\
\hline C3 & $16 \cdot 9$ & $45 \cdot 0$ & $17 \cdot 4$ & $43 \cdot 0$ & 0.5 & $-2 \cdot 0$ & 162 & $0 \cdot 64$ & $0 \cdot 015$ \\
\hline $\mathrm{C} 4$ & $18 \cdot 9$ & $59 \cdot 0$ & $19 \cdot 3$ & $62 \cdot 5$ & $0 \cdot 4$ & $3 \cdot 5$ & 178 & $0 \cdot 89$ & $0 \cdot 015$ \\
\hline C5 & $21 \cdot 2$ & $86 \cdot 7$ & $21 \cdot 5$ & $85 \cdot 4$ & $0 \cdot 3$ & $-1 \cdot 3$ & 164 & $0 \cdot 95$ & $0 \cdot 011$ \\
\hline C6 & $23 \cdot 0$ & $115 \cdot 0$ & $22 \cdot 8$ & $111 \cdot 1$ & $-0 \cdot 2$ & $-3 \cdot 9$ & 147 & $1 \cdot 42$ & $0 \cdot 013$ \\
\hline
\end{tabular}




\section{TABLES 8-13.}

\section{Data Obtained from the Experiments on the Maintenance} Requirements of Female Plaice.

TABle 8: A5.

\begin{tabular}{|c|c|c|c|c|c|c|c|c|c|c|c|c|}
\hline \multirow{2}{*}{$\begin{array}{l}\text { Date } \\
(1930)\end{array}$} & \multicolumn{2}{|c|}{$\begin{array}{c}\text { Size } \\
\text { of fish. }\end{array}$} & \multicolumn{2}{|c|}{$\begin{array}{l}\text { Growth } \\
\text { per } \\
\text { period. }\end{array}$} & \multirow{2}{*}{$\begin{array}{c}\text { Weight } \\
\text { of food } \\
\text { per } \\
\text { period. } \\
\text { (gm.) }\end{array}$} & \multirow[t]{2}{*}{$\begin{array}{c}\text { No. of } \\
\text { days } \\
\text { in } \\
\text { period. }\end{array}$} & \multirow{2}{*}{$\begin{array}{c}\text { Average } \\
\text { weight } \\
\text { of food } \\
\text { per day. } \\
\text { (gm.) }\end{array}$} & \multirow{2}{*}{$\begin{array}{l}\text { Ratio of } \\
\text { food per } \\
\text { day/ } \\
\text { /average } \\
\text { body-wt. } \\
\text { for } \\
\text { period. }\end{array}$} & \multirow{2}{*}{$\begin{array}{c}\text { Total } \\
\text { wt. of } \\
\text { food } \\
\text { to date. } \\
\text { (gm.) }\end{array}$} & \multirow{2}{*}{$\begin{array}{c}\text { No. of } \\
\text { days } \\
\text { since } \\
\text { com- } \\
\text { mence- } \\
\text { ment of } \\
\text { expt. }\end{array}$} & \multicolumn{2}{|c|}{$\begin{array}{l}\text { Cumulative } \\
\text { growth. }\end{array}$} \\
\hline & $\begin{array}{l}\text { Lth. } \\
\text { (cm.) }\end{array}$ & $\begin{array}{l}\text { Wt. } \\
\text { (gm.) }\end{array}$ & $\begin{array}{l}\text { Lth. } \\
\text { (cm.) }\end{array}$ & $\underset{\text { (gm.) }}{\text { Wt. }}$ & & & & & & & $\begin{array}{l}\text { Lth. } \\
\text { (cm.) }\end{array}$ & $\begin{array}{l}\text { Wt. } \\
\text { (gm.) }\end{array}$ \\
\hline June 16 & $12 \cdot 2$ & $17 \cdot 3$ & - & - & - & - & - & - & - & - & - & - \\
\hline ,, 23 & $12 \cdot 4$ & $17 \cdot 8$ & $0 \cdot 2$ & 0.5 & $3 \cdot 5$ & 7 & $0 \cdot 50$ & 0.029 & 3.5 & 7 & $0 \cdot 2$ & 0.5 \\
\hline July 7 & $12 \cdot 6$ & $19 \cdot 0$ & $0 \cdot 2$ & $1 \cdot 2$ & $8 \cdot 0$ & 14 & 0.57 & $0 \cdot 031$ & $11 \cdot 5$ & 21 & 0.4 & $1 \cdot 7$ \\
\hline,$\quad 21$ & $12 \cdot 8$ & $20 \cdot 0$ & $0 \cdot 2$ & $1 \cdot 0$ & $6 \cdot 6$ & 14 & $0 \cdot 47$ & 0.025 & $18 \cdot 1$ & 35 & $0 \cdot 6$ & $2 \cdot 7$ \\
\hline Aug. 6 & $12 \cdot 9$ & $20 \cdot 5$ & $0 \cdot 1$ & 0.5 & $7 \cdot 5$ & 16 & $0 \cdot 47$ & 0.023 & $25 \cdot 6$ & 51 & 0.7 & $3 \cdot 2$ \\
\hline,$\quad 21$ & $13 \cdot 0$ & $21 \cdot 2$ & $0 \cdot 1$ & 0.7 & $6 \cdot 6$ & 15 & $0 \cdot 44$ & 0.021 & $32 \cdot 2$ & 66 & $0 \cdot 8$ & $3 \cdot 9$ \\
\hline Sept. 5 & $13 \cdot 2$ & $20 \cdot 6$ & $0 \cdot 2$ & $-0 \cdot 6$ & $6 \cdot 0$ & 15 & $0 \cdot 40$ & 0.019 & $38 \cdot 2$ & 81 & $1 \cdot 0$ & $3 \cdot 3$ \\
\hline,$\quad 19$ & $13 \cdot 2$ & $21 \cdot 8$ & nil & $1 \cdot 2$ & $5 \cdot 5$ & 14 & $0 \cdot 39$ & 0.018 & $43 \cdot 7$ & 95 & $1 \cdot 0$ & $4 \cdot 5$ \\
\hline Oct. 6 & $13 \cdot 3$ & $22 \cdot 3$ & 0.1 & $0 \cdot 5$ & $8 \cdot 0$ & 17 & $0 \cdot 47$ & 0.021 & $51 \cdot 7$ & 112 & $1 \cdot 1$ & $5 \cdot 0$ \\
\hline,,$\quad 22$ & $13 \cdot 3$ & $22 \cdot 3$ & nil & nil & $5 \cdot 5$ & 16 & $0 \cdot 34$ & 0.015 & $57 \cdot 2$ & 128 & $1 \cdot 1$ & $5 \cdot 0$ \\
\hline Nov. 6 & $13 \cdot 3$ & $22 \cdot 0$ & nil & $-0 \cdot 3$ & $5 \cdot 0$ & 15 & $0 \cdot 33$ & 0.015 & $62 \cdot 2$ & 143 & $1 \cdot 1$ & $4 \cdot 7$ \\
\hline
\end{tabular}

Table 9: A6 (a and b).

\begin{tabular}{|c|c|c|c|c|c|c|c|c|c|c|c|c|}
\hline May 14 & $15 \cdot 6$ & $33 \cdot 0$ & - & - & - & - & - & - & - & - & - & - \\
\hline,$\quad 26$ & $15 \cdot 5$ & $31 \cdot 8$ & $-0 \cdot 1$ & $-1 \cdot 2$ & $6 \cdot 3$ & 12 & 0.52 & 0.016 & $6 \cdot 3$ & 12 & $-0 \cdot 1$ & $-1 \cdot 2$ \\
\hline June 9 & $15 \cdot 5$ & $30 \cdot 8$ & nil & $-1 \cdot 0$ & $6 \cdot 3$ & 14 & $0 \cdot 45$ & 0.014 & $12 \cdot 6$ & 26 & $-0 \cdot 1$ & $-2 \cdot 2$ \\
\hline,,$\quad 23$ & $15 \cdot 5$ & $30 \cdot 1$ & nil & -0.7 & $3 \cdot 9$ & 14 & $0 \cdot 28$ & 0.009 & $16 \cdot 5$ & 40 & $-0 \cdot 1$ & $-2 \cdot 9$ \\
\hline July 7 & $15 \cdot 5$ & $29 \cdot 1$ & nil & $-1 \cdot 0$ & $6 \cdot 2$ & 14 & $0 \cdot 44$ & 0.015 & $22 \cdot 7$ & 54 & $-0 \cdot 1$ & $-3 \cdot 9$ \\
\hline,,$\quad 21$ & $15 \cdot 3$ & $28 \cdot 0$ & -0.2 & $-1 \cdot 1$ & $1 \cdot 0$ & 14 & 0.04 & - & $23 \cdot 7$ & 68 & -0.3 & $-5 \cdot 0$ \\
\hline Aug. 6 & $15 \cdot 3$ & $27 \cdot 0$ & nil & $-1 \cdot 0$ & $5 \cdot 2$ & 16 & $0 \cdot 32$ & 0.012 & $28 \cdot 9$ & 84 & -0.3 & $-6 \cdot 0$ \\
\hline Aug. 22 & $15 \cdot 2$ & $35 \cdot 0$ & - & - & - & - & - & - & - & - & - & \\
\hline Sept. 5 & $15 \cdot 2$ & $34 \cdot 2$ & nil & -0.8 & $3 \cdot 5$ & 15 & $0 \cdot 24$ & $0 \cdot 007$ & $3 \cdot 5$ & 15 & nil & -0.8 \\
\hline,$\quad 19$ & $15 \cdot 2$ & $32 \cdot 3$ & nil & $-1 \cdot 9$ & $4 \cdot 6$ & 14 & $0 \cdot 33$ & 0.010 & $8 \cdot 1$ & 29 & nil & $-2 \cdot 7$ \\
\hline Oct. 6 & $15 \cdot 2$ & $31 \cdot 5$ & nil & -0.8 & $5 \cdot 6$ & 17 & $0 \cdot 33$ & 0.010 & $13 \cdot 7$ & 46 & nil & $-3 \cdot 5$ \\
\hline,,$\quad 22$ & $15 \cdot 2$ & $30 \cdot 2$ & nil & $-1 \cdot 3$ & $4 \cdot 9$ & 16 & $0 \cdot 31$ & 0.010 & $18 \cdot 6$ & 62 & nil & $-4 \cdot 8$ \\
\hline Nor. 6 & $15 \cdot 2$ & $30 \cdot 1$ & nil & -0.1 & $7 \cdot 6$ & 15 & 0.51 & $0 \cdot 017$ & $26 \cdot 2$ & 77 & nil & -4.9 \\
\hline
\end{tabular}

Table 10: A2.

\begin{tabular}{|c|c|c|c|c|c|c|c|c|c|c|c|c|}
\hline June 11 & $17 \cdot 3$ & $49 \cdot 0$ & - & - & - & - & - & - & - & - & - & \\
\hline & $17 \cdot 3$ & $46 \cdot 8$ & nil & $-2 \cdot 2$ & $9 \cdot 0$ & 12 & $0 \cdot 75$ & $0 \cdot 016$ & $9 \cdot 0$ & 12 & nil & $-2 \cdot 2$ \\
\hline July 7 & $17 \cdot 5$ & $50 \cdot 8$ & $0 \cdot 2$ & $4 \cdot 0$ & $11 \cdot 0$ & 14 & $0 \cdot 79$ & 0.016 & $20 \cdot 0$ & 26 & $0 \cdot 2$ & $1 \cdot 8$ \\
\hline , 21 & $17 \cdot 5$ & $52 \cdot 0$ & nil & $1 \cdot 2$ & $9 \cdot 0$ & 14 & $0 \cdot 64$ & 0.012 & $29 \cdot 0$ & 40 & $0 \cdot 2$ & $3 \cdot 0$ \\
\hline Aug. $\quad 6$ & $17 \cdot 6$ & $51 \cdot 0$ & $0 \cdot 1$ & $-1 \cdot 0$ & $9 \cdot 5$ & 16 & $0 \cdot 59$ & 0.011 & $38 \cdot 5$ & 56 & $0 \cdot 3$ & $2 \cdot 0$ \\
\hline,$\quad 21$ & $17 \cdot 6$ & $52 \cdot 0$ & nil & $1 \cdot 0$ & $10 \cdot 0$ & 15 & $0 \cdot 67$ & 0.013 & $48 \cdot 5$ & 71 & $0 \cdot 3$ & $3 \cdot 0$ \\
\hline Sept. 5 & $17 \cdot 6$ & $49 \cdot 4$ & nil & $-2 \cdot 6$ & $10 \cdot 0$ & 15 & $0 \cdot 67$ & 0.013 & $58 \cdot 5$ & 86 & $0 \cdot 3$ & $0 \cdot 4$ \\
\hline $\begin{array}{ll}, \quad 19\end{array}$ & $17 \cdot 6$ & $52 \cdot 2$ & nil & $2 \cdot 8$ & $11 \cdot 5$ & 14 & $0 \cdot 82$ & 0.016 & $70 \cdot 0$ & 100 & $0 \cdot 3$ & $3 \cdot 2$ \\
\hline Oct. & $17 \cdot 6$ & $53 \cdot 5$ & nil & $1 \cdot 3$ & $14 \cdot 0$ & 17 & $0 \cdot 82$ & 0.016 & $84 \cdot 0$ & 117 & $0 \cdot 3$ & $4 \cdot 5$ \\
\hline , 22 & $17 \cdot 7$ & $53 \cdot 1$ & 0.1 & -0.4 & $11 \cdot 0$ & 16 & $0 \cdot 69$ & 0.013 & $95 \cdot 0$ & 133 & $0 \cdot 4$ & $4 \cdot 1$ \\
\hline Nov. 6 & $17 \cdot 7$ & $53 \cdot 0$ & nil & $-0 \cdot 1$ & $7 \cdot 0$ & 15 & $0 \cdot 47$ & 0.009 & $102 \cdot 0$ & 148 & $0 \cdot 4$ & $4 \cdot 0$ \\
\hline
\end{tabular}


Table 11: A4.

\begin{tabular}{|c|c|c|c|c|c|c|c|c|c|c|c|c|}
\hline \multirow{2}{*}{$\begin{array}{c}\text { Date } \\
(1930)\end{array}$} & \multicolumn{2}{|c|}{$\begin{array}{c}\text { Size } \\
\text { of fish. }\end{array}$} & \multicolumn{2}{|c|}{$\begin{array}{l}\text { Growth } \\
\text { per } \\
\text { period. }\end{array}$} & \multirow{2}{*}{$\begin{array}{c}\text { Weight } \\
\text { of food } \\
\text { per } \\
\text { period. } \\
\text { (gm.) }\end{array}$} & \multirow[t]{2}{*}{$\begin{array}{c}\text { No. of } \\
\text { days } \\
\text { in } \\
\text { period. }\end{array}$} & \multirow{2}{*}{$\begin{array}{c}\text { Average } \\
\text { weight } \\
\text { of food } \\
\text { per day. } \\
\text { (gm.) }\end{array}$} & \multirow{2}{*}{$\begin{array}{c}\text { Ratio of } \\
\text { food per } \\
\text { day/ } \\
\text { /average } \\
\text { body-wt. } \\
\text { for } \\
\text { period }\end{array}$} & \multirow{2}{*}{$\begin{array}{c}\text { Total } \\
\text { wt. of } \\
\text { food } \\
\text { to date. } \\
\text { (gm.) }\end{array}$} & \multirow{2}{*}{$\begin{array}{l}\text { No. of } \\
\text { days } \\
\text { since } \\
\text { com- } \\
\text { mence- } \\
\text { ment of } \\
\text { expt. }\end{array}$} & \multicolumn{2}{|c|}{$\begin{array}{l}\text { Cumulative } \\
\text { growth. }\end{array}$} \\
\hline & $\begin{array}{l}\text { Lth. } \\
\text { (cm.) }\end{array}$ & $\underset{(\mathrm{gm} .)}{\mathrm{Wt} .}$ & $\underset{\text { (cm.) }}{\text { Lth. }}$ & $\underset{\text { (gm.) }}{\text { Wt. }}$ & & & & & & & $\begin{array}{l}\text { Lth. } \\
\text { (em.) }\end{array}$ & $\underset{\text { (gm.) }}{\text { Wt. }}$ \\
\hline May 12 & $19 \cdot 8$ & $71 \cdot 0$ & - & - & - & - & - & - & - & - & - & \\
\hline,$\quad 26$ & $19 \cdot 8$ & $67 \cdot 7$ & nil & -33 & $12 \cdot 0$ & 14 & $0 \cdot 86$ & 0.012 & $12 \cdot 0$ & 14 & nil & -3 \\
\hline June 9 & $19 \cdot 9$ & $67 \cdot 9$ & $0 \cdot 1$ & $0 \cdot 2$ & $11 \cdot 7$ & 14 & $0 \cdot 84$ & 0.012 & $23 \cdot 7$ & 28 & $0 \cdot 1$ & -3 \\
\hline & $20 \cdot 0$ & $67 \cdot 8$ & $0 \cdot 1$ & -0.1 & $11 \cdot 7$ & 14 & $0 \cdot 84$ & 0.012 & 35.4 & 42 & $0 \cdot 2$ & -3 \\
\hline July 7 & $20 \cdot 1$ & $67 \cdot 7$ & $0 \cdot 1$ & -0.1 & $13 \cdot 0$ & 14 & $0 \cdot 93$ & $0 \cdot 014$ & 484 & 56 & $0 \cdot 3$ & -3 \\
\hline,$\quad 21$ & $20 \cdot 1$ & $68 \cdot 0$ & nil & $0 \cdot 3$ & $13 \cdot 0$ & 14 & $0 \cdot 93$ & $0 \cdot 014$ & $61 \cdot 4$ & 70 & $0 \cdot 3$ & -3 \\
\hline Aug. 6 & $20 \cdot 2$ & $68 \cdot 5$ & $0 \cdot 1$ & $0 \cdot 5$ & $14 \cdot 5$ & 16 & $0 \cdot 91$ & 0.013 & $75 \cdot 9$ & 86 & $0 \cdot 4$ & - : \\
\hline ," 21 & $20 \cdot 2$ & $66 \cdot 5$ & nil & $-2 \cdot 0$ & $13 \cdot 0$ & 15 & $0 \cdot 87$ & $0 \cdot 013$ & $88 \cdot 9$ & 101 & $0 \cdot 4$ & -4 \\
\hline Sept. 5 & $20 \cdot 4$ & $66 \cdot 3$ & $0 \cdot 2$ & $-0 \cdot 2$ & $13 \cdot 5$ & 15 & $0 \cdot 90$ & 0.014 & $102 \cdot 4$ & 116 & $0 \cdot 6$ & $-4 \cdot 7$ \\
\hline,$\quad 19$ & $20 \cdot 2$ & $66 \cdot 4$ & $-0 \cdot 2$ & $0 \cdot 1$ & $13 \cdot 5$ & 14 & $0 \cdot 96$ & $0 \cdot 014$ & $115 \cdot 9$ & 130 & $0 \cdot 4$ & $-4 \cdot 1$ \\
\hline Oct. 6 & $20 \cdot 3$ & $68 \cdot 6$ & $0 \cdot 1$ & $2 \cdot 2$ & $16 \cdot 3$ & 17 & $0 \cdot 96$ & 0.014 & $132 \cdot 2$ & 147 & 0.5 & $\begin{array}{l}-2 \cdot 4 \\
-2.2\end{array}$ \\
\hline $\begin{array}{lr}22 \\
\text { Nov }\end{array}$ & $\begin{array}{l}20 \cdot 4 \\
20 \cdot 2\end{array}$ & $\begin{array}{l}68 \cdot 8 \\
68 \cdot 3\end{array}$ & $\begin{array}{r}0.1 \\
-0.2\end{array}$ & $\begin{array}{r}0.2 \\
-0.5\end{array}$ & $\begin{array}{r}14 \cdot 5 \\
8 \cdot 3\end{array}$ & 16 & $0 \cdot 91$ & 0.013 & $146 \cdot 7$ & 163 & $0 \cdot 6$ & $-2 \cdot 2$ \\
\hline & & & & & $8 \cdot 3$ & 15 & 0.55 & $0 \cdot 008$ & $155 \cdot 0$ & 178 & $0 \cdot 4$ & \\
\hline
\end{tabular}

TABle 12: A3.

\begin{tabular}{|c|c|c|c|c|c|c|c|c|c|c|c|}
\hline June 12 & $22 \cdot 0 \quad 101 \cdot 5$ & - & - & - & - & - & - & - & - & - & - \\
\hline ,, 23 & $97 \cdot 5$ & nil & $-4 \cdot 0$ & $13 \cdot 0$ & 11 & $1 \cdot 18$ & 0.012 & $13 \cdot 0$ & 11 & nil & $-4 \cdot 0$ \\
\hline July 7 & $22 \cdot 0$ & nil & 0.4 & $17 \cdot 5$ & 14 & $1 \cdot 25$ & 0.013 & $30 \cdot 5$ & 25 & nil & $-3 \cdot 6$ \\
\hline,$\quad 21$ & $21 \cdot 9 \quad 100 \cdot 0$ & -0.1 & $2 \cdot 1$ & $17 \cdot 0$ & 14 & $1 \cdot 21$ & 0.012 & $47 \cdot 6$ & 39 & $-0 \cdot 1$ & $-1 \cdot 5$ \\
\hline Aug. 6 & $97 \cdot 0$ & $0 \cdot 1$ & $-3 \cdot 0$ & $18 \cdot 5$ & 16 & $1 \cdot 16$ & 0.012 & $66 \cdot 0$ & 55 & nil & $-4 \cdot 5$ \\
\hline,$\quad 21$ & $96 \cdot 0$ & nil & $-1 \cdot 0$ & $17 \cdot 5$ & 15 & $1 \cdot 17$ & 0.012 & $83 \cdot 5$ & 70 & nil & $-5 \cdot 5$ \\
\hline pt. 5 & $93 \cdot 5$ & $0 \cdot 2$ & $-2 \cdot 5$ & $17 \cdot 0$ & 15 & $1 \cdot 13$ & 0.012 & $100 \cdot 5$ & 85 & $0 \cdot 2$ & $-8 \cdot 0$ \\
\hline 19 & $95 \cdot 6$ & -0.4 & $2 \cdot 1$ & $20 \cdot 0$ & 14 & $1 \cdot 43$ & 0.015 & $120 \cdot 5$ & 99 & $-0 \cdot 2$ & $-5 \cdot 9$ \\
\hline 6 & $96 \cdot 8$ & $0 \cdot 1$ & $1 \cdot 2$ & $24 \cdot 5$ & 17 & $1 \cdot 44$ & $0 \cdot 015$ & $145 \cdot 0$ & 116 & $-0 \cdot \overline{1}$ & $-4 \cdot 7$ \\
\hline 22 & $96 \cdot 3$ & $0 \cdot 1$ & $-0 \cdot 5$ & $20 \cdot 6$ & 16 & $1 \cdot 29$ & 0.013 & $165 \cdot 6$ & 132 & nil & $-5 \cdot 2$ \\
\hline ov. 6 & $95 \cdot 2$ & nil & $-1 \cdot 1$ & $13 \cdot 0$ & 15 & 0.87 & 0.009 & $178 \cdot 6$ & 147 & nil & $-6 \cdot 3$ \\
\hline
\end{tabular}

Table 13: A1.

\begin{tabular}{|c|c|c|c|c|c|c|c|c|c|c|c|c|}
\hline May 12 & $24 \cdot 5$ & $132 \cdot 0$ & - & - & - & - & - & - & - & - & - & - \\
\hline,,$\quad 26$ & $24 \cdot 6$ & $133 \cdot 8$ & $0 \cdot 1$ & 1.8 & $13 \cdot 7$ & 14 & $0 \cdot 98$ & 0.007 & $13 \cdot 7$ & 14 & $0 \cdot 1$ & $1 \cdot 8$ \\
\hline June 9 & $24 \cdot 6$ & $132 \cdot 0$ & nil & $-1 \cdot 8$ & $19 \cdot 0$ & 14 & $1 \cdot 36$ & 0.010 & $32 \cdot 7$ & 28 & $0 \cdot 1$ & nil \\
\hline ,, 23 & $24 \cdot 6$ & $134 \cdot 0$ & nil & $2 \cdot 0$ & $21 \cdot 0$ & 14 & $1 \cdot 50$ & 0.011 & $53 \cdot 7$ & 42 & $0 \cdot 1$ & $2 \cdot 0$ \\
\hline July 7 & $24 \cdot 6$ & $133 \cdot 2$ & nil & -0.8 & $18 \cdot 5$ & 14 & $1 \cdot 32$ & 0.010 & $72 \cdot 2$ & 56 & $0 \cdot 1$ & $1 \cdot 2$ \\
\hline,$\quad 21$ & $24 \cdot 6$ & $138 \cdot 0$ & nil & $4 \cdot 8$ & $18 \cdot 5$ & 14 & $1 \cdot 32$ & 0.010 & $90 \cdot 7$ & 70 & $0 \cdot 1$ & $6 \cdot 0$ \\
\hline ug. 6 & $24 \cdot 8$ & $136 \cdot 0$ & 0.2 & $-2 \cdot 0$ & $20 \cdot 0$ & 16 & $1 \cdot 25$ & $0 \cdot 009$ & $110 \cdot 7$ & 86 & $0 \cdot 3$ & $4 \cdot 0$ \\
\hline,$\quad 21$ & $24 \cdot 7$ & $136 \cdot 0$ & -0.1 & nil & $19 \cdot 0$ & 15 & $1 \cdot 27$ & 0.009 & $129 \cdot 7$ & 101 & $0 \cdot 2$ & $4 \cdot 0$ \\
\hline Sept. 5 & $24 \cdot 7$ & $136 \cdot 2$ & nil & $0 \cdot 2$ & $18 \cdot 5$ & 15 & $1 \cdot 23$ & 0.009 & $148 \cdot 2$ & 116 & $0 \cdot 2$ & $4 \cdot 2$ \\
\hline 19 & $24 \cdot 7$ & $135 \cdot 5$ & nil & $-0 \cdot 7$ & $18 \cdot 5$ & 14 & $1 \cdot 32$ & 0.010 & $166 \cdot 7$ & 130 & $0 \cdot 2$ & $3 \cdot 5$ \\
\hline 6 & $24 \cdot 7$ & $140 \cdot 4$ & nil & $4 \cdot 9$ & $21 \cdot 5$ & 17 & $1 \cdot 26$ & $0 \cdot 009$ & $188 \cdot 2$ & 147 & $0 \cdot 2$ & $8 \cdot 4$ \\
\hline 22 & $24 \cdot 8$ & $140 \cdot 8$ & $0 \cdot 1$ & $0 \cdot 4$ & $20 \cdot 0$ & 16 & $1 \cdot 25$ & $0 \cdot 009$ & $208 \cdot 2$ & 163 & $0 \cdot 3$ & $8 \cdot 8$ \\
\hline v. 6 & $24 \cdot 7$ & $136 \cdot 9$ & -0.1 & $-3 \cdot 9$ & $13 \cdot 0$ & 15 & $0 \cdot 87$ & 0.006 & $221 \cdot 2$ & 178 & 0.2 & $4 \cdot 9$ \\
\hline
\end{tabular}


TABLE 14.

Summarised Data Concerning the Matntenance Requirements of the Female Plaice, A1-A6.

\begin{tabular}{|c|c|c|c|c|c|c|c|c|c|}
\hline \multirow[b]{2}{*}{$\begin{array}{l}\text { Fish } \\
\text { No. }\end{array}$} & \multicolumn{2}{|c|}{$\begin{array}{c}\text { Initial } \\
\text { size. }\end{array}$} & \multicolumn{2}{|c|}{$\begin{array}{c}\text { Final } \\
\text { size. }\end{array}$} & \multicolumn{2}{|c|}{ Growth. } & \multirow{2}{*}{$\begin{array}{c}\text { Days } \\
\text { in } \\
\text { period. }\end{array}$} & \multirow{2}{*}{$\begin{array}{l}\text { Average } \\
\text { weight } \\
\text { of food } \\
\text { per day. } \\
\text { (gm.) }\end{array}$} & \multirow{2}{*}{$\begin{array}{c}\text { Ratio } \\
\text { Food per } \\
\text { day/ } \\
\text { /mid } \\
\text { body- } \\
\text { weight } \\
\text { per period. }\end{array}$} \\
\hline & $\begin{array}{l}\text { Lth. } \\
\text { (cm.) }\end{array}$ & $\begin{array}{l}\text { Wt. } \\
\text { (gm.) }\end{array}$ & $\begin{array}{l}\text { Lth. } \\
(\mathrm{cm} .)\end{array}$ & $\begin{array}{l}\text { Wt. } \\
\text { (gm.) }\end{array}$ & $\begin{array}{l}\text { Lth. } \\
\text { (cm.) }\end{array}$ & $\begin{array}{l}\text { Wt. } \\
\text { (gm.) }\end{array}$ & & & \\
\hline $\mathrm{A} 5$ & $12 \cdot 2$ & $17 \cdot 3$ & $13 \cdot 3$ & $22 \cdot 0$ & $1 \cdot 1$ & $4 \cdot 7$ & 143 & $0 \cdot 43$ & $0 \cdot 022$ \\
\hline $\mathrm{A} 6 \mathrm{a}$ & $15 \cdot 6$ & $33 \cdot 0$ & $15 \cdot 3$ & $27 \cdot 0$ & $-0 \cdot 3$ & $-6 \cdot 0$ & 84 & $0 \cdot 34$ & $0 \cdot 011$ \\
\hline b & $15 \cdot 2$ & $35 \cdot 0$ & $15 \cdot 2$ & $30 \cdot 1$ & nil & $-4 \cdot 9$ & 77 & $0 \cdot 34$ & $0 \cdot 010$ \\
\hline $\mathrm{A} 2$ & $17 \cdot 3$ & $49 \cdot 0$ & $17 \cdot 7$ & $53 \cdot 0$ & $0 \cdot 4$ & $4 \cdot 0$ & 148 & $0 \cdot 69$ & $0 \cdot 014$ \\
\hline $\mathrm{A} 4$ & $19 \cdot 8$ & $71 \cdot 0$ & $20 \cdot 2$ & $68 \cdot 3$ & $0 \cdot 4$ & $-2 \cdot 7$ & 178 & $0 \cdot 87$ & $0 \cdot 012$ \\
\hline A3 & $22 \cdot 0$ & 101.5 & $22 \cdot 0$ & $95 \cdot 2$ & nil & $-6 \cdot 3$ & 147 & $1 \cdot 21$ & $0 \cdot 012$ \\
\hline $\mathrm{Al}$ & $24 \cdot 5$ & $132 \cdot 0$ & $24 \cdot 7$ & $136 \cdot 9$ & $0 \cdot 2$ & $4 \cdot 9$ & 178 & $1 \cdot 24$ & $0 \cdot 009$ \\
\hline
\end{tabular}


TABLE 15.

Summarised Data Concerning Maximum Requirements and Growth in Male and Female Plaice.

\begin{tabular}{|c|c|c|c|c|c|c|c|c|c|c|c|c|c|}
\hline \multirow{2}{*}{$\begin{array}{l}\text { Fish } \\
\text { No. }\end{array}$} & \multirow{2}{*}{ Sex. } & \multicolumn{2}{|c|}{$\begin{array}{l}\text { Initial } \\
\text { size. }\end{array}$} & \multicolumn{2}{|c|}{$\begin{array}{l}\text { Final } \\
\text { size. }\end{array}$} & \multicolumn{2}{|c|}{ Growth. } & \multirow{2}{*}{\multicolumn{2}{|c|}{ Period. }} & \multirow{2}{*}{$\begin{array}{c}\text { Days } \\
\text { in } \\
\text { Period. }\end{array}$} & \multirow{2}{*}{$\begin{array}{l}\text { Total } \\
\text { food } \\
\text { per the } \\
\text { period. } \\
\text { (gm.) }\end{array}$} & \multirow{2}{*}{$\begin{array}{l}\text { Average } \\
\text { weight } \\
\text { of food } \\
\text { per day } \\
\text { for the } \\
\text { period. } \\
\text { (gm.) }\end{array}$} & \multirow{2}{*}{$\begin{array}{c}\text { Gm. of } \\
\text { food per } \\
1.0 \mathrm{gm} . \\
\text { increase } \\
\text { in weight } \\
\text { of fish. }\end{array}$} \\
\hline & & $\begin{array}{l}\text { Lth. } \\
(\mathrm{cm} .)\end{array}$ & $\begin{array}{c}\text { Wt. } \\
\text { (gm.) }\end{array}$ & $\begin{array}{l}\text { Lth. } \\
\text { (em.) }\end{array}$ & $\begin{array}{l}\text { Wt. } \\
\text { (gm.) }\end{array}$ & $\begin{array}{l}\text { Lth. } \\
\text { (cm.) }\end{array}$ & $\begin{array}{l}\text { Wt. } \\
\text { (gm.) }\end{array}$ & & To & & & & \\
\hline D1 & రే & $15 \cdot 0$ & $35 \cdot 8$ & $19 \cdot 2$ & $77 \cdot 1$ & $4 \cdot 2$ & $41 \cdot 3$ & $28: 5$ & $6: 11$ & 162 & 475 & $3 \cdot 0$ & $11 \cdot 5$ \\
\hline D2 & $\hat{\sigma}$ & $13 \cdot 5$ & $22 \cdot 0$ & $17 \cdot 4$ & $52 \cdot 1$ & $3 \cdot 9$ & $30 \cdot 1$ & $12: 5$ & $6: 11$ & 178 & 358 & $2 \cdot 0$ & $11 \cdot 9$ \\
\hline D3 & 0 & $14 \cdot 0$ & $26 \cdot 5$ & $17 \cdot 4$ & $51 \cdot 0$ & $3 \cdot 4$ & $24 \cdot 5$ & $12: 5$ & $5: 9$ & 116 & 250 & $2 \cdot 2$ & $10 \cdot 2$ \\
\hline D4 & 0 & $13 \cdot 5$ & $23 \cdot 0$ & $16 \cdot 4$ & $44 \cdot 5$ & $2 \cdot 9$ & $21 \cdot 5$ & $12: 5$ & $5: 9$ & 116 & 196 & $1 \cdot 7$ & $9 \cdot 1$ \\
\hline D5 & $\hat{0}$ & $14 \cdot 6$ & $31 \cdot 7$ & $16 \cdot 8$ & $47 \cdot 2$ & $2 \cdot 2$ & $15 \cdot 5$ & $9: 6$ & $5: 9$ & 88 & 159 & $1 \cdot 8$ & $10 \cdot 3$ \\
\hline D6 & ot & $13 \cdot 1$ & $18 \cdot 2$ & $15 \cdot 1$ & $33 \cdot 0$ & $2 \cdot 0$ & $14 \cdot 8$ & $29: 5$ & $5: 9$ & 99 & 159 & $1 \cdot 6$ & $10 \cdot 7$ \\
\hline B1 & 우 & $14 \cdot 7$ & $26 \cdot 7$ & $18 \cdot 0$ & $55 \cdot 7$ & $3 \cdot 3$ & $29 \cdot 0$ & $17: 6$ & $6: 11$ & 142 & 331 & $2 \cdot 3$ & $11 \cdot 4$ \\
\hline B2 & q & $15 \cdot 5$ & $30 \cdot 5$ & $18 \cdot 2$ & $64 \cdot 1$ & $2 \cdot 7$ & $33 \cdot 6$ & $17: 6$ & $6: 11$ & 142 & 352 & $2 \cdot 5$ & $10 \cdot 5$ \\
\hline B3 & 우 & $12 \cdot 9$ & $19 \cdot 7$ & $17 \cdot 3$ & $50 \cdot 3$ & $4 \cdot 4$ & $30 \cdot 6$ & $26: 5$ & $6: 11$ & 165 & 296 & $1 \cdot 8$ & $9 \cdot 7$ \\
\hline B5 & 우 & $15 \cdot 5$ & $34 \cdot 5$ & $19 \cdot 2$ & $82 \cdot 5$ & $3 \cdot 7$ & $48 \cdot 0$ & $26: 5$ & $21: 8$ & 87 & 308 & $3 \cdot 5$ & $8 \cdot 5$ \\
\hline
\end{tabular}


TABLES 16-21.

Maximum Requirements and Growth of Male Platce.

TABLe 16: D1.

\begin{tabular}{|c|c|c|c|c|c|c|c|c|c|c|c|c|c|}
\hline \multirow{2}{*}{$\begin{array}{l}\text { Date. } \\
(1930)\end{array}$} & \multicolumn{2}{|c|}{$\begin{array}{l}\text { Size } \\
\text { of } \\
\text { fish. }\end{array}$} & \multirow[t]{2}{*}{ Wt.//th. ${ }^{3}$} & \multicolumn{2}{|c|}{$\begin{array}{l}\text { Growth } \\
\text { per } \\
\text { period. }\end{array}$} & \multirow{2}{*}{$\begin{array}{c}\text { Total } \\
\text { food } \\
\text { per } \\
\text { period. } \\
\text { (gm.) }\end{array}$} & \multirow[t]{2}{*}{$\begin{array}{c}\text { Gm. of } \\
\text { food } \\
\text { per } \\
1.0 \mathrm{gm} \text {. } \\
\text { increase } \\
\text { in } \\
\text { weight } \\
\text { of fish. }\end{array}$} & \multirow[t]{2}{*}{$\begin{array}{c}\text { No of } \\
\text { days } \\
\text { in } \\
\text { period. }\end{array}$} & \multirow{2}{*}{$\begin{array}{c}\text { Average } \\
\text { food } \\
\text { per day } \\
\text { during } \\
\text { each } \\
\text { period. } \\
\text { (gm.) }\end{array}$} & \multirow{2}{*}{$\begin{array}{l}\text { Percent- } \\
\text { age } \\
\text { growth } \\
\text { in wt. }\end{array}$} & \multirow{2}{*}{$\begin{array}{c}\text { Total } \\
\text { food } \\
\text { to date } \\
\\
(\mathrm{gm} .)\end{array}$} & \multicolumn{2}{|c|}{$\begin{array}{l}\text { Cumulative } \\
\text { growth. }\end{array}$} \\
\hline & $\begin{array}{l}\text { Lth. } \\
\text { (cm.) }\end{array}$ & $\begin{array}{l}\text { Wt. } \\
\text { (gm.) }\end{array}$ & & $\begin{array}{l}\text { Lth. } \\
\text { (em.) }\end{array}$ & $\begin{array}{l}\text { Wt. } \\
\text { (gm.) }\end{array}$ & & & & & & & $\begin{array}{l}\text { Lth. } \\
(\mathrm{em} .)\end{array}$ & Wt. \\
\hline May 28 & $15 \cdot 0$ & $35 \cdot 8$ & 0.011 & - & - & - & 一 & - & - & - & - & - & - \\
\hline June 9 & $16 \cdot 2$ & 46.0 & $0 \cdot 011$ & $1 \cdot 2$ & $10 \cdot 2$ & $43 \cdot 3$ & $4 \cdot 2$ & 12 & $3 \cdot 61$ & 28.5 & 43 & $1 \cdot 2$ & $10 \cdot 2$ \\
\hline$\Rightarrow \quad 23$ & $17 \cdot 0$ & $51 \cdot 3$ & 0.010 & 0.8 & $5 \cdot 3$ & $57 \cdot 1$ & $10 \cdot 8$ & 14 & $4 \cdot 08$ & 11.5 & 100 & $2 \cdot 0$ & $15 \cdot 5$ \\
\hline July 7 & $17 \cdot 3$ & $52 \cdot 5$ & 0.010 & $0 \cdot 3$ & $1 \cdot 2$ & $35 \cdot 3$ & $29 \cdot 4$ & 14 & $2 \cdot 52$ & $2 \cdot 3$ & 136 & $2 \cdot 3$ & $16 \cdot 7$ \\
\hline$" 21$ & $17 \cdot 6$ & $58 \cdot 0$ & 0.011 & $0 \cdot 3$ & $5 \cdot 5$ & $40 \cdot 0$ & $7 \cdot 3$ & 14 & $2 \cdot 86$ & $10 \cdot 5$ & 176 & $2 \cdot 6$ & $22 \cdot 2$ \\
\hline Aug. 6 & $17 \cdot 8$ & $57 \cdot 7$ & 0.010 & $0 \cdot 2$ & $-0 \cdot 3$ & $38 \cdot 6$ & - & 16 & $2 \cdot 41$ & - & 214 & $2 \cdot 8$ & $21 \cdot 9$ \\
\hline & $18 \cdot 1$ & $60 \cdot 5$ & 0.010 & $0 \cdot 3$ & $2 \cdot 8$ & $32 \cdot 2$ & $11 \cdot 5$ & 15 & $2 \cdot 15$ & $5 \cdot 0$ & 246 & $3 \cdot 1$ & $24 \cdot 7$ \\
\hline Sept. 5 & $18 \cdot 3$ & $60 \cdot 8$ & 0.010 & $0 \cdot 2$ & $0 \cdot 3$ & $41 \cdot 1$ & $137 \cdot 0$ & 15 & $2 \cdot 74$ & 0.5 & 288 & $3 \cdot 3$ & $25 \cdot 0$ \\
\hline , 20 & $18 \cdot 4$ & $64 \cdot 3$ & 0.010 & $0 \cdot 1$ & $3 \cdot 5$ & $39 \cdot 7$ & $11 \cdot 3$ & 15 & $2 \cdot 65$ & $5 \cdot 8$ & 327 & $3 \cdot 4$ & 28.5 \\
\hline Oct. 6 & $18 \cdot 8$ & $70 \cdot 0$ & 0.011 & $0 \cdot 4$ & $5 \cdot 7$ & $54 \cdot 1$ & $9 \cdot 5$ & 16 & $3 \cdot 38$ & $8 \cdot 9$ & 381 & 3.8 & $34 \cdot 2$ \\
\hline $\begin{array}{l}\Rightarrow \quad 22\end{array}$ & $19 \cdot 1$ & $72 \cdot 2$ & 0.01 & $0 \cdot 3$ & $2 \cdot 2$ & $44 \cdot 8$ & $20 \cdot 4$ & 16 & $2 \cdot 80$ & $3 \cdot 1$ & 426 & $4 \cdot 1$ & $36 \cdot 4$ \\
\hline Nov. 6 & $19 \cdot 2$ & $77 \cdot 1$ & 0.011 & $0 \cdot 1$ & $4 \cdot 9$ & 48.5 & $9 \cdot 9$ & 15 & $3 \cdot 23$ & $6 \cdot 8$ & 475 & $4 \cdot 2$ & $41 \cdot 3$ \\
\hline
\end{tabular}

Table $17:$ D2.

\begin{tabular}{|c|c|c|c|c|c|c|c|c|c|c|c|c|c|}
\hline May 12 & $13 \cdot 5$ & $22 \cdot 0$ & $0 \cdot 009$ & - & - & - & - & - & - & - & - & - & - \\
\hline & $13 \cdot 5$ & $22 \cdot 7$ & $0 \cdot 009$ & nil & $0 \cdot 7$ & $14 \cdot 0$ & $20 \cdot 0$ & 14 & $1 \cdot 00$ & $3 \cdot 2$ & 14 & nil & $0 \cdot 7$ \\
\hline June 9 & $14 \cdot 3$ & $29 \cdot 7$ & $0 \cdot 010$ & $0 \cdot 8$ & $7 \cdot 0$ & $30 \cdot 2$ & $4 \cdot 3$ & 14 & $2 \cdot 16$ & 30.8 & 44 & $0 \cdot 8$ & $7 \cdot 7$ \\
\hline & $15 \cdot 0$ & $33 \cdot 0$ & $0 \cdot 010$ & $0 \cdot 7$ & $3 \cdot 3$ & $36 \cdot 0$ & $10 \cdot 9$ & 14 & 2.58 & $11 \cdot 1$ & 80 & 1.5 & $11 \cdot 0$ \\
\hline July 7 & $15 \cdot 3$ & $35 \cdot 2$ & 0.010 & $0 \cdot 3$ & $2 \cdot 2$ & 26.8 & 12.2 & 14 & 1.91 & 6.7 & 107 & 1.8 & $13 \cdot 2$ \\
\hline & $15 \cdot 7$ & $39 \cdot 0$ & 0.010 & $0 \cdot 4$ & $3 \cdot 8$ & $32 \cdot 7$ & 8.6 & 14 & $2 \cdot 34$ & $10 \cdot 8$ & 140 & $2 \cdot 2$ & $17 \cdot 0$ \\
\hline Aug. 6 & $16 \cdot 1$ & $43 \cdot 2$ & 0.010 & 0.4 & $4 \cdot 2$ & $42 \cdot 2$ & $10 \cdot 0$ & 16 & $2 \cdot 64$ & $10 \cdot 8$ & 182 & $2 \cdot 6$ & $21 \cdot 2$ \\
\hline \# 21 & $16 \cdot 6$ & $46 \cdot 5$ & $0 \cdot 010$ & 0.5 & $3 \cdot 3$ & $34 \cdot 0$ & $10 \cdot 3$ & 15 & $2 \cdot 27$ & $7 \cdot 6$ & 216 & $3 \cdot 1$ & $24 \cdot 5$ \\
\hline Sept. 5 & $16 \cdot 7$ & $47 \cdot 0$ & 0.010 & $0 \cdot 1$ & $0 \cdot 5$ & $31 \cdot 4$ & $62 \cdot 8$ & 15 & $2 \cdot 09$ & $1 \cdot 1$ & 247 & $3 \cdot 2$ & $25 \cdot 0$ \\
\hline , 20 & $16 \cdot 9$ & $46 \cdot 9$ & 0.010 & $0 \cdot 2$ & $-0 \cdot 1$ & 16.8 & - & 15 & $1 \cdot 12$ & & 264 & $3 \cdot 4$ & $24 \cdot 9$ \\
\hline Oct. 6 & $17 \cdot 1$ & $52 \cdot 4$ & $0 \cdot 010$ & $0 \cdot 2$ & $5 \cdot 5$ & $35 \cdot 0$ & $6 \cdot 4$ & 16 & $2 \cdot 19$ & $11 \cdot 7$ & 299 & $3 \cdot 6$ & $30 \cdot 4$ \\
\hline 22 & $17 \cdot 3$ & $53 \cdot 0$ & $0 \cdot 010$ & $0 \cdot 2$ & $0 \cdot 6$ & $29 \cdot 0$ & $48 \cdot 3$ & 16 & $1 \cdot 81$ & $1 \cdot 1$ & 328 & $3 \cdot 8$ & $31 \cdot 0$ \\
\hline ช. 6 & $17 \cdot 4$ & $52 \cdot 1$ & $0 \cdot 010$ & $0 \cdot 1-$ & -0.9 & $29 \cdot 7$ & 一 & 15 & 1.98 & - & 358 & $3 \cdot 9$ & $30 \cdot 1$ \\
\hline
\end{tabular}

Table 18: D3.

\begin{tabular}{|c|c|c|c|c|c|c|c|c|c|c|c|c|c|}
\hline May 12 & $14 \cdot 0$ & 26.5 & 0.010 & - & - & - & - & - & - & - & - & - & - \\
\hline & $14 \cdot 0$ & $25 \cdot 0$ & 0.009 & nil & $-1 \cdot 5$ & $9 \cdot 3$ & - & 14 & $0 \cdot 66$ & & 9 & nil & $-1 \cdot 5$ \\
\hline June 9 & $14 \cdot 4$ & 28.5 & 0.010 & $0 \cdot 4$ & $3 \cdot 5$ & $24 \cdot 6$ & $7 \cdot 0$ & 14 & $1 \cdot 76$ & $14 \cdot 0$ & 34 & $0 \cdot 4$ & $2 \cdot 0$ \\
\hline " 23 & $14 \cdot 9$ & $33 \cdot 3$ & 0.010 & 0.5 & $4 \cdot 8$ & $39 \cdot 1$ & $8 \cdot 1$ & 14 & $2 \cdot 80$ & 16.8 & 73 & $0 \cdot 9$ & $6 \cdot 8$ \\
\hline $\begin{array}{ll}\text { July } \quad 7\end{array}$ & $15 \cdot 5$ & $38 \cdot 4$ & $0 \cdot 010$ & $0 \cdot 6$ & $5 \cdot 1$ & & $6 \cdot 8$ & 14 & $2 \cdot 46$ & $15 \cdot 3$ & 107 & 1.5 & 11.9 \\
\hline$\Longrightarrow \quad 21$ & $16 \cdot 3$ & $49 \cdot 0$ & 0.011 & 0.8 & $10 \cdot 6$ & $44 \cdot 8$ & $4 \cdot 2$ & 14 & $3 \cdot 20$ & $27 \cdot 6$ & 152 & $2 \cdot 3$ & $22 \cdot 5$ \\
\hline Aug. 6 & $17 \cdot 0$ & $53 \cdot 5$ & $0 \cdot 01$ & $0 \cdot 7$ & $4 \cdot 5$ & & 10.8 & & $3 \cdot($ & $9 \cdot 2$ & 201 & $3 \cdot 0$ & $27 \cdot 0$ \\
\hline , 21 & $17 \cdot 4$ & $54 \cdot 5$ & 0.011 & $0 \cdot 4$ & $1 \cdot 0$ & $32 \cdot 9$ & $2 \cdot 9$ & 15 & $2 \cdot 19$ & 1.9 & 234 & $3 \cdot 4$ & 28.0 \\
\hline Sept. 5 & $17 \cdot 4$ & $51 \cdot 0$ & 0.010 & & $-3 \cdot 5$ & $16 \cdot 4$ & - & 15 & 1.09 & - & 250 & 3.4 & $24 \cdot 5$ \\
\hline
\end{tabular}


TABLe 19: D4.

\begin{tabular}{|c|c|c|c|c|c|c|c|c|c|c|c|c|c|}
\hline \multirow{2}{*}{$\begin{array}{l}\text { Date } \\
(1930)\end{array}$} & \multicolumn{2}{|c|}{$\begin{array}{l}\text { Size } \\
\text { of } \\
\text { fish. }\end{array}$} & \multirow[t]{2}{*}{ Wt./Lth. ${ }^{3}$} & \multicolumn{2}{|c|}{$\begin{array}{l}\text { Growth } \\
\text { per } \\
\text { period. }\end{array}$} & \multirow{2}{*}{$\begin{array}{c}\text { Total } \\
\text { food } \\
\text { per } \\
\text { period. } \\
\text { (gm.) }\end{array}$} & \multirow{2}{*}{$\begin{array}{c}\text { Gm. of } \\
\text { food } \\
\text { per } \\
1.0 \mathrm{gm} . \\
\text { increase } \\
\text { in } \\
\text { weight } \\
\text { of fish. }\end{array}$} & \multirow{2}{*}{$\begin{array}{c}\text { No. of } \\
\text { days } \\
\text { in } \\
\text { period. }\end{array}$} & \multirow{2}{*}{$\begin{array}{c}\text { A verage } \\
\text { food } \\
\text { per day } \\
\text { during } \\
\text { each } \\
\text { period. } \\
\text { (gm) }\end{array}$} & \multirow{2}{*}{$\begin{array}{l}\text { Percent- } \\
\text { age } \\
\text { growth } \\
\text { in wt. }\end{array}$} & \multirow{2}{*}{ 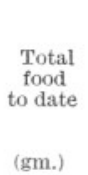 } & \multicolumn{2}{|c|}{$\begin{array}{c}\text { Cumulative } \\
\text { growth. }\end{array}$} \\
\hline & $\begin{array}{l}\text { Lth. } \\
\text { (em.) }\end{array}$ & $\begin{array}{l}\text { Wt. } \\
\text { (gm.) }\end{array}$ & & $\begin{array}{l}\text { Lth. } \\
(\mathrm{cm} .)\end{array}$ & $\begin{array}{l}\text { Wt. } \\
\text { (gm.) }\end{array}$ & & & & & & & $\begin{array}{l}\text { Lth. } \\
\text { (em.) }\end{array}$ & $\begin{array}{l}\text { Wt. } \\
\text { (gm.) }\end{array}$ \\
\hline May 12 & $13 \cdot 5$ & $23 \cdot 0$ & $0 \cdot 009$ & - & - & - & - & - & - & - & - & - & - \\
\hline,$\quad 26$ & $13 \cdot 5$ & $21 \cdot 5$ & 0.009 & nil & $-1 \cdot 5$ & $11 \cdot 4$ & - & 14 & 0.81 & - & 11 & nil & -1.5 \\
\hline June 9 & $13 \cdot 7$ & $25 \cdot 8$ & 0.010 & 0.2 & $4 \cdot 3$ & $19 \cdot 0$ & $4 \cdot 4$ & 14 & $1 \cdot 36$ & $20 \cdot 0$ & 30 & $0 \cdot 2$ & $2 \cdot 8$ \\
\hline,,$\quad 23$ & $14 \cdot 0$ & $27 \cdot 0$ & $0 \cdot 010$ & $0 \cdot 3$ & $1 \cdot 2$ & $20 \cdot 9$ & $17 \cdot 4$ & 14 & $1 \cdot 49$ & $4 \cdot 6$ & 51 & $0 \cdot 5$ & $4 \cdot 0$ \\
\hline July 7 & $14 \cdot 3$ & $29 \cdot 8$ & $0 \cdot 010$ & $0 \cdot 3$ & $2 \cdot 8$ & $21 \cdot 3$ & $7 \cdot 6$ & 14 & 1.52 & $10 \cdot 4$ & 73 & 0.8 & 6.8 \\
\hline,$\quad 21$ & $14 \cdot 8$ & $33 \cdot 5$ & 0.010 & 0.5 & $3 \cdot 7$ & $26 \cdot 9$ & $7 \cdot 3$ & 14 & 1.92 & $12 \cdot 4$ & 99 & $1 \cdot 3$ & 10.5 \\
\hline Aug. 6 & $15 \cdot 5$ & $39 \cdot 7$ & 0.010 & 0.7 & $6 \cdot 2$ & $35 \cdot 6$ & $5 \cdot 7$ & 16 & $2 \cdot 22$ & $18 \cdot 5$ & 135 & $2 \cdot 0$ & $16 \cdot 7$ \\
\hline,$\quad 21$ & $16 \cdot 0$ & $42 \cdot 0$ & 0.010 & 0.5 & $2 \cdot 3$ & $30 \cdot 5$ & $13 \cdot 3$ & 15 & $2 \cdot 03$ & $5 \cdot 8$ & 166 & $2 \cdot 5$ & $19 \cdot 0$ \\
\hline Sept. 5 & $16 \cdot 4$ & $44 \cdot 5$ & 0.010 & 0.4 & $2 \cdot 5$ & $30 \cdot 3$ & $12 \cdot 1$ & 15 & $2 \cdot 02$ & $6 \cdot 0$ & 196 & $2 \cdot 9$ & $21 \cdot 5$ \\
\hline
\end{tabular}

Table 20: D5.

\begin{tabular}{|c|c|c|c|c|c|c|c|c|c|c|c|c|}
\hline June 9 & $14 \cdot 6$ & $31 \cdot 7$ & 0.010 & - & - & - & - & - & - & - & & \\
\hline,$\quad 23$ & $15 \cdot 0$ & $33 \cdot 2$ & 0.010 & $0 \cdot 4$ & $1 \cdot 5$ & $21 \cdot 9$ & $14 \cdot 6$ & 14 & $1 \cdot 56$ & $4 \cdot 7$ & 22 & $0 \cdot 4$ \\
\hline July 7 & $15 \cdot 4$ & $34 \cdot 8$ & 0.010 & 0.4 & $1 \cdot 6$ & $18 \cdot 9$ & $11 \cdot 8$ & 14 & $1 \cdot 35$ & $4 \cdot 8$ & 41 & 0.8 \\
\hline,$\quad 21$ & $15 \cdot 6$ & $38 \cdot 0$ & 0.010 & $0 \cdot 2$ & $3 \cdot 2$ & $20 \cdot 8$ & $6 \cdot 5$ & 14 & $1 \cdot 49$ & $9 \cdot 2$ & 62 & 1.0 \\
\hline Aug. 6 & $16 \cdot 0$ & $41 \cdot 0$ & 0.010 & 0.4 & $3 \cdot 0$ & $34 \cdot 3$ & $11 \cdot 4$ & 16 & $2 \cdot 14$ & $8 \cdot 0$ & 96 & $1 \cdot 4$ \\
\hline ," 21 & $16 \cdot 4$ & $42 \cdot 5$ & 0.010 & $0 \cdot 4$ & 1.5 & $29 \cdot 4$ & $19 \cdot 6$ & 15 & 1.96 & $3 \cdot 7$ & 125 & $1 \cdot 8$ \\
\hline Sept. 5 & $16 \cdot 8$ & $47 \cdot 2$ & 0.010 & $0 \cdot 4$ & $4 \cdot 7$ & $34 \cdot 1$ & $7 \cdot 3$ & 15 & $2 \cdot 27$ & $11 \cdot 1$ & 159 & $2 \cdot 2$ \\
\hline
\end{tabular}

Table 21: D6.

\begin{tabular}{|c|c|c|c|c|c|c|c|c|c|c|c|c|c|}
\hline May 29 & $13 \cdot 1$ & $18 \cdot 2$ & $0 \cdot 008$ & - & - & - & - & - & - & - & - & - & \\
\hline June 9 & $13 \cdot 2$ & $19 \cdot 3$ & 0.008 & $0 \cdot 1$ & $1 \cdot 1$ & $15 \cdot 9$ & $14 \cdot 5$ & 11 & 1.45 & $6 \cdot 0$ & 16 & $0 \cdot 1$ & $1 \cdot 1$ \\
\hline , $\quad 23$ & $13 \cdot 4$ & $20 \cdot 5$ & $0 \cdot 009$ & $0 \cdot 2$ & $1 \cdot 2$ & $22 \cdot 6$ & 18.8 & 14 & $1 \cdot 61$ & $6 \cdot 2$ & 38 & $0 \cdot 3$ & $2 \cdot 3$ \\
\hline July & $13 \cdot 7$ & $21 \cdot 6$ & 0.008 & $0 \cdot 3$ & $1 \cdot 1$ & $16 \cdot 5$ & $15 \cdot 0$ & 14 & $1 \cdot 18$ & $5 \cdot 3$ & 55 & 0.6 & $3 \cdot 4$ \\
\hline 21 & $13 \cdot 8$ & $24 \cdot 0$ & $0 \cdot 009$ & $0 \cdot 1$ & $2 \cdot 4$ & $17 \cdot 1$ & $7 \cdot 1$ & 14 & $1 \cdot 22$ & $11 \cdot 1$ & 72 & $0 \cdot 7$ & $5 \cdot 8$ \\
\hline Aug. & $14 \cdot 3$ & $26 \cdot 0$ & 0.009 & 0.5 & $2 \cdot 0$ & $31 \cdot 8$ & $15 \cdot 9$ & 16 & 1.99 & $8 \cdot 3$ & 104 & $1 \cdot 2$ & $7 \cdot 8$ \\
\hline 21 & $14 \cdot 6$ & $28 \cdot 5$ & $0 \cdot 009$ & $0 \cdot 3$ & $2 \cdot 5$ & $22 \cdot 8$ & $9 \cdot 1$ & 15 & 1.52 & $9 \cdot 6$ & 127 & $1 \cdot 5$ & $10 \cdot 3$ \\
\hline & $15 \cdot 1$ & $33 \cdot 0$ & 0.010 & 0.5 & $4 \cdot 5$ & $32 \cdot 4$ & $7 \cdot 2$ & 15 & $2 \cdot 16$ & $15 \cdot 8$ & 159 & $2 \cdot 0$ & $14 \cdot 8$ \\
\hline
\end{tabular}


TABLES 22-27.

Maximum Requirements and Growth of Female Plaice.

TABLE 22: B1.

\begin{tabular}{|c|c|c|c|c|c|c|c|c|c|c|c|c|c|}
\hline \multirow{2}{*}{$\begin{array}{l}\text { Date. } \\
(1930)\end{array}$} & \multicolumn{2}{|c|}{$\begin{array}{l}\text { Size } \\
\text { of } \\
\text { fish. }\end{array}$} & \multirow[t]{2}{*}{ Wt./Lth. ${ }^{3}$} & \multicolumn{2}{|c|}{$\begin{array}{l}\text { Growth } \\
\text { per } \\
\text { period. }\end{array}$} & \multirow{2}{*}{$\begin{array}{l}\text { Total } \\
\text { food } \\
\text { per } \\
\text { period. } \\
\text { (gm.) }\end{array}$} & \multirow{2}{*}{$\begin{array}{l}\mathrm{Gm} \text {. of } \\
\text { food } \\
\text { per } \\
1.0 \mathrm{gm} . \\
\text { increase } \\
\text { in } \\
\text { weight } \\
\text { of fish. }\end{array}$} & \multirow{2}{*}{$\begin{array}{c}\text { No. of } \\
\text { days } \\
\text { in } \\
\text { period. }\end{array}$} & \multirow{2}{*}{$\begin{array}{l}\text { Average } \\
\text { food } \\
\text { per day } \\
\text { during } \\
\text { each } \\
\text { period. } \\
\text { (gm.) }\end{array}$} & \multirow{2}{*}{$\begin{array}{l}\text { Percent- } \\
\text { age } \\
\text { growth } \\
\text { in wt. }\end{array}$} & \multirow{2}{*}{$\begin{array}{l}\text { Total } \\
\text { food } \\
\text { to date } \\
\\
(\mathrm{gm} .)\end{array}$} & \multicolumn{2}{|c|}{$\begin{array}{l}\text { Cumulative } \\
\text { growth. }\end{array}$} \\
\hline & $\begin{array}{l}\text { Lth. } \\
\text { (em.) }\end{array}$ & $\begin{array}{l}\text { Wt. } \\
\text { (gm.) }\end{array}$ & & $\begin{array}{l}\text { Lth. } \\
\text { (cm.) }\end{array}$ & $\begin{array}{l}\text { Wt. } \\
(\mathrm{gm} .)\end{array}$ & & & & & & & $\begin{array}{l}\text { Lth. } \\
\text { (cm.) }\end{array}$ & $\begin{array}{l}\text { Wt. } \\
\text { (gm.) }\end{array}$ \\
\hline June 17 & $14 \cdot 7$ & $26 \cdot 7$ & $0 \cdot 008$ & - & - & - & - & - & - & - & - & - & - \\
\hline & $14 \cdot 8$ & $28 \cdot 5$ & 0.009 & $0 \cdot 1$ & $1 \cdot 8$ & $8 \cdot 4$ & $4 \cdot 7$ & 6 & $1 \cdot 40$ & $6 \cdot 7$ & 8 & 0.1 & $1 \cdot 8$ \\
\hline July 7 & $15 \cdot 3$ & $34 \cdot 4$ & 0.010 & 0.5 & $5 \cdot 9$ & $40 \cdot 1$ & $6 \cdot 8$ & 14 & $2 \cdot 86$ & $20 \cdot 7$ & 48 & $0 \cdot 6$ & $7 \cdot 7$ \\
\hline,$\quad 21$ & $15 \cdot 8$ & $43 \cdot 0$ & 0.011 & $0 \cdot 5$ & $8 \cdot 6$ & $40 \cdot 2$ & $4 \cdot 7$ & 14 & $2 \cdot 87$ & $25 \cdot 0$ & 89 & $1 \cdot 1$ & $16 \cdot 3$ \\
\hline Aug. 6 & $16 \cdot 7$ & $51 \cdot 0$ & 0.011 & 0.9 & $8 \cdot 0$ & $49 \cdot 9$ & $6 \cdot 2$ & 16 & $3 \cdot 12$ & $18 \cdot 6$ & 139 & $2 \cdot 0$ & $24 \cdot 3$ \\
\hline,$\quad 21$ & $17 \cdot 4$ & $58 \cdot 5$ & 0.011 & $0 \cdot 7$ & $7 \cdot 5$ & $52 \cdot 2$ & $7 \cdot 0$ & 15 & $3 \cdot 48$ & $14 \cdot 7$ & 191 & $2 \cdot 7$ & $31 \cdot 8$ \\
\hline Sept. 5 & $17 \cdot 8$ & 58.9 & 0.010 & $0 \cdot 4$ & $0 \cdot 4$ & $34 \cdot 6$ & $86 \cdot 5$ & 15 & $2 \cdot 31$ & 0.7 & 225 & $3 \cdot 1$ & $32 \cdot 2$ \\
\hline,$\quad 20$ & $17 \cdot 9$ & $59 \cdot 5$ & 0.010 & 0.1 & $0 \cdot 6$ & $30 \cdot 1$ & $50 \cdot 2$ & 15 & $2 \cdot 01$ & $1 \cdot 0$ & 255 & $3 \cdot 2$ & $32 \cdot 8$ \\
\hline Oct. 6 & $18 \cdot 0$ & $61 \cdot 6$ & 0.011 & $0 \cdot 1$ & $2 \cdot 1$ & $34 \cdot 8$ & $16 \cdot 6$ & 16 & $2 \cdot 17$ & $3 \cdot 5$ & 290 & $3 \cdot 3$ & $34 \cdot 9$ \\
\hline,$\quad 22$ & $18 \cdot 1$ & $55 \cdot 7$ & 0.010 & $0 \cdot 1$ & $-5 \cdot 9$ & $19 \cdot 2$ & - & 16 & $1 \cdot 20$ & - & 309 & $3 \cdot 4$ & $29 \cdot 0$ \\
\hline Nov. 6 & $18 \cdot 0$ & $55 \cdot 7$ & $0 \cdot 010$ & $-0 \cdot 1$ & nil & $21 \cdot 6$. & - & 15 & $1 \cdot 4$ & - & 331 & $3 \cdot 3$ & $29 \cdot 0$ \\
\hline
\end{tabular}

Table 23: B2.

\begin{tabular}{|c|c|c|c|c|c|c|c|c|c|c|c|c|c|}
\hline June 17 & $15 \cdot 5$ & $30 \cdot 5$ & 0.008 & $\rightarrow$ & $\overline{0}$ & $\overline{0}$ & - & - & - & - & - & - & - \\
\hline & $15 \cdot 5$ & $30 \cdot 0$ & 0008 & nil & -0.5 & $3 \cdot 8$ & - & 6 & 0.63 & - & 4 & nil & -0.5 \\
\hline July 7 & $15 \cdot 6$ & $32 \cdot 2$ & 0.008 & $0 \cdot 1$ & $2 \cdot 2$ & $18 \cdot 5$ & $8 \cdot 4$ & 14 & $1 \cdot 32$ & $6 \cdot 7$ & 22 & 0.1 & $1 \cdot 7$ \\
\hline$\Rightarrow \quad 21$ & $16 \cdot 1$ & $42 \cdot 5$ & $0 \cdot 010$ & $0 \cdot 5$ & $10 \cdot 3$ & $49 \cdot 9$ & $4 \cdot 8$ & 14 & $3 \cdot 56$ & $32 \cdot 0$ & 72 & 0.6 & $12 \cdot 0$ \\
\hline Aug. $\quad 6$ & $16 \cdot 7$ & $48 \cdot 3$ & $0 \cdot 010$ & $0 \cdot 6$ & $5 \cdot 8$ & $50 \cdot 9$ & $8 \cdot 8$ & 16 & $3 \cdot 18$ & $13 \cdot 6$ & 123 & $1 \cdot 2$ & $17 \cdot 8$ \\
\hline , 21 & $17 \cdot 2$ & $54 \cdot 5$ & $0 \cdot 011$ & $0 \cdot 5$ & $6 \cdot 2$ & $46 \cdot 5$ & $7 \cdot 5$ & 15 & $3 \cdot 10$ & $12 \cdot 8$ & $170^{\circ}$ & $1 \cdot 7$ & $24 \cdot 0$ \\
\hline Sept. 5 & $17 \cdot 5$ & $55 \cdot 8$ & $0 \cdot 010$ & $0 \cdot 3$ & $1 \cdot 3$ & $40 \cdot 0$ & $30 \cdot 8$ & 15 & $2 \cdot 67$ & $2 \cdot 4$ & 210 & $2 \cdot 0$ & $25 \cdot 3$ \\
\hline , 20 & $17 \cdot 4$ & $60 \cdot 4$ & 0.011 & $-0 \cdot 1$ & $4 \cdot 6$ & $42 \cdot 1$ & $9 \cdot 2$ & 15 & $2 \cdot 81$ & $8 \cdot 2$ & 252 & $1 \cdot 9$ & $29 \cdot 9$ \\
\hline Oct. $\quad 6$ & $18 \cdot 0$ & $63 \cdot 5$ & $0 \cdot 011$ & $0 \cdot 6$ & $3 \cdot 1$ & $43 \cdot 1$ & $13 \cdot 9$ & 16 & $2 \cdot 69$ & $5 \cdot 1$ & 295 & $2 \cdot 5$ & $33 \cdot 0$ \\
\hline,$\quad 22$ & $18 \cdot 2$ & $63 \cdot 7$ & 0.011 & $0 \cdot 2$ & $0 \cdot 2$ & $28 \cdot 4$ & $142 \cdot 0$ & 16 & $1 \cdot 77$ & $0 \cdot 3$ & 323 & $2 \cdot 7$ & $33 \cdot 2$ \\
\hline Nov. 6 & $18 \cdot 2$ & $64 \cdot 1$ & 0.011 & nil & $0 \cdot 4$ & $28 \cdot 9$ & $72 \cdot 2$ & 15 & $1 \cdot 93$ & $0 \cdot 6$ & 352 & $2 \cdot 7$ & $33 \cdot 6$ \\
\hline
\end{tabular}

TABLe 24: B3.

\begin{tabular}{|c|c|c|c|c|c|c|c|c|c|c|c|c|c|}
\hline May 26 & $12 \cdot 9$ & $19 \cdot 7$ & $0 \cdot 009$ & - & 一 & - & - & - & - & - & - & - & \\
\hline June 9 & $13 \cdot 5$ & $24 \cdot 1$ & 0.010 & $0 \cdot 6$ & $4 \cdot 4$ & $29 \cdot 1$ & $6 \cdot 6$ & 14 & $2 \cdot 08$ & $22 \cdot 3$ & 29 & 0.6 & \\
\hline,,$\quad 23$ & $14 \cdot 7$ & $30 \cdot 0$ & $0 \cdot 009$ & $1 \cdot 2$ & $5 \cdot 9$ & $31 \cdot 6$ & $5 \cdot 4$ & 14 & $2 \cdot 26$ & $24 \cdot 5$ & 61 & $1 \cdot 8$ & 10 \\
\hline July 7 & $15 \cdot 3$ & $35 \cdot 3$ & 0.010 & $0 \cdot 6$ & $5 \cdot 3$ & $34 \cdot 4$ & $6 \cdot 5$ & 14 & $2 \cdot 46$ & $17 \cdot 7$ & 95 & $2 \cdot 4$ & \\
\hline,$\quad 21$ & $15 \cdot 5$ & $36 \cdot 5$ & $0 \cdot 010$ & $0 \cdot 2$ & $1 \cdot 2$ & $18 \cdot 2$ & $15 \cdot 2$ & 14 & $1 \cdot 30$ & $3 \cdot 4$ & 113 & $2 \cdot 6$ & \\
\hline Aug. 6 & $15 \cdot 9$ & $38 \cdot 8$ & 0.010 & $0 \cdot 4$ & $2 \cdot 3$ & $28 \cdot 9$ & $12 \cdot 6$ & 16 & $1 \cdot 81$ & $6 \cdot 3$ & 142 & $3 \cdot 0$ & \\
\hline ," 21 & $16 \cdot 3$ & $42 \cdot 0$ & 0.010 & $0 \cdot 4$ & $3 \cdot 2$ & $28 \cdot 7$ & $9 \cdot 0$ & 15 & $1 \cdot 91$ & $8 \cdot 2$ & 171 & $3 \cdot 4$ & 22 \\
\hline $\begin{array}{l}5 \text { Sept. } 5 \\
, \quad 20\end{array}$ & $16 \cdot 5$ & $\frac{43 \cdot 8}{-}$ & 0.010 & $0 \cdot 2$ & $1 \cdot 8$ & $26 \cdot 2$ & $14 \cdot 6$ & 15 & $1 \cdot 75$ & $\begin{array}{l}4 \cdot 3 \\
x\end{array}$ & 197 & $3 \cdot 6$ & \\
\hline Oct. 6 & $17 \cdot 2$ & $48 \cdot 4$ & $0 \cdot 010$ & $0 \cdot 7$ & $4 \cdot 6$ & $49 \cdot 8$ & $10 \cdot 8$ & 32 & $1 \cdot 56$ & $\mathrm{x}$ & 247 & $4 \cdot 3$ & \\
\hline,$\quad 22$ & $17 \cdot 4$ & $49 \cdot 7$ & 0.009 & $0 \cdot 2$ & $1 \cdot 3$ & $23 \cdot 8$ & $18 \cdot 3$ & 16 & $1 \cdot 49$ & $2 \cdot 7$ & 271 & $4 \cdot 5$ & 30 \\
\hline Nov. 6 & $17 \cdot 3$ & $50 \cdot 3$ & 0.010 & $-0 \cdot 1$ & $0 \cdot 6$ & $25 \cdot 1$ & $41 \cdot 8$ & 15 & $1 \cdot 67$ & $1 \cdot 2$ & 296 & $4 \cdot 4$ & \\
\hline
\end{tabular}


Table 25: B5.

\begin{tabular}{|c|c|c|c|c|c|c|c|c|c|c|c|c|c|}
\hline \multirow{2}{*}{$\begin{array}{l}\text { Date. } \\
(1930)\end{array}$} & \multicolumn{2}{|c|}{$\begin{array}{l}\text { Size } \\
\text { of } \\
\text { fish. }\end{array}$} & \multirow[t]{2}{*}{ Wt./Lth. ${ }^{3}$} & \multicolumn{2}{|c|}{$\begin{array}{l}\text { Growth } \\
\text { per } \\
\text { period. }\end{array}$} & \multirow{2}{*}{$\begin{array}{c}\text { Total } \\
\text { food } \\
\text { per } \\
\text { period. } \\
\text { (gm.) }\end{array}$} & \multirow[t]{2}{*}{$\begin{array}{l}\text { Gm. of } \\
\text { food } \\
\text { per } \\
1.0 \mathrm{gm} \text {. } \\
\text { increase } \\
\text { in } \\
\text { weight } \\
\text { of fish. }\end{array}$} & \multirow[t]{2}{*}{$\begin{array}{c}\text { No. of } \\
\text { days } \\
\text { in } \\
\text { period. }\end{array}$} & \multirow{2}{*}{$\begin{array}{c}\text { Average } \\
\text { food } \\
\text { per day } \\
\text { during } \\
\text { each } \\
\text { period. } \\
\text { (gm.) }\end{array}$} & \multirow{2}{*}{$\begin{array}{l}\text { Percent- } \\
\text { age } \\
\text { growth } \\
\text { in wt. }\end{array}$} & \multirow{2}{*}{$\begin{array}{l}\text { Total } \\
\text { food } \\
\text { to date } \\
\\
\text { (gm.) }\end{array}$} & \multicolumn{2}{|c|}{$\begin{array}{l}\text { Cumulative } \\
\text { growth. }\end{array}$} \\
\hline & $\begin{array}{l}\text { Lth. } \\
\text { (em.) }\end{array}$ & $\begin{array}{c}\text { Wt. } \\
\text { (gm.) }\end{array}$ & & $\begin{array}{l}\text { Lth. } \\
\text { (cm.) }\end{array}$ & $\begin{array}{l}\text { Wt. } \\
\text { (gm.) }\end{array}$ & & & & & & & $\begin{array}{l}\text { Lth. } \\
\text { (c.m.) }\end{array}$ & $\begin{array}{l}\text { Wt. } \\
\text { (gm) }\end{array}$ \\
\hline May 26 & $15 \cdot 5$ & $34 \cdot 5$ & $0 \cdot 009$ & - & - & - & - & - & - & - & - & - & - \\
\hline June 9 & $15 \cdot 9$ & $42 \cdot 5$ & 0.011 & $0 \cdot 4$ & $8 \cdot 0$ & $38 \cdot 7$ & $4 \cdot 8$ & 14 & $2 \cdot 76$ & $23 \cdot 2$ & 39 & $0 \cdot 4$ & $8 \cdot 0$ \\
\hline,$\quad 23$ & $16 \cdot 9$ & $53 \cdot 0$ & 0.011 & $1 \cdot 0$ & $10 \cdot 5$ & $64 \cdot 5$ & $6 \cdot 1$ & 14 & $4 \cdot 61$ & $24 \cdot 7$ & 103 & $1 \cdot 4$ & $18 \cdot 5$ \\
\hline July 7 & $17 \cdot 8$ & $64 \cdot 0$ & 0.011 & 0.9 & $11 \cdot 0$ & $61 \cdot 5$ & $5 \cdot 6$ & 14 & $4 \cdot 39$ & $20 \cdot 8$ & 165 & $2 \cdot 3$ & $29 \cdot 5$ \\
\hline , 21 & $18 \cdot 1$ & $69 \cdot 0$ & $0 \cdot 012$ & $0 \cdot 3$ & $5 \cdot 0$ & $41 \cdot 5$ & $8 \cdot 3$ & 14 & $2 \cdot 96$ & $7 \cdot 8$ & 206 & $2 \cdot 6$ & $34 \cdot 5$ \\
\hline Aug. 6 & $18 \cdot 6$ & $73 \cdot 8$ & 0.012 & 0.5 & $4 \cdot 8$ & $44 \cdot 3$ & $9 \cdot 2$ & 16 & $2 \cdot 77$ & $7 \cdot 0$ & 250 & $3 \cdot 1$ & $39 \cdot 3$ \\
\hline 21 & $19 \cdot 2$ & $82 \cdot 5$ & 0.012 & $0 \cdot 6$ & $8 \cdot 7$ & $47 \cdot 8$ & $5 \cdot 5$ & 15 & $3 \cdot 12$ & $1 \cdot 2$ & 298 & $3 \cdot 7$ & $48 \cdot 0$ \\
\hline
\end{tabular}

Table 26: B4.

\begin{tabular}{|c|c|c|c|c|c|c|c|c|c|c|c|c|c|}
\hline May 26 & $12 \cdot 3$ & $17 \cdot 2$ & $0 \cdot 009$ & - & 一 & - & 一 & - & - & - & - & - & - \\
\hline June 9 & $13 \cdot 0$ & $22 \cdot 4$ & $0 \cdot 010$ & 0.7 & $5 \cdot 2$ & $26 \cdot 6$ & $5 \cdot 1$ & 14 & $1 \cdot 90$ & $30 \cdot 2$ & 27 & $0 \cdot 7$ & $5 \cdot 2$ \\
\hline,,$\quad 23$ & $14 \cdot 1$ & $29 \cdot 2$ & $0 \cdot 010$ & $1 \cdot 1$ & $6 \cdot 8$ & $39 \cdot 1$ & $5 \cdot 7$ & 14 & $2 \cdot 79$ & $30 \cdot 4$ & 66 & $1 \cdot 8$ & $12 \cdot 0$ \\
\hline July 7 & $15 \cdot 1$ & $37 \cdot 0$ & 0.011 & $1 \cdot 0$ & $7 \cdot 8$ & $42 \cdot 4$ & $5 \cdot 4$ & 14 & $3 \cdot 03$ & $26 \cdot 7$ & 108 & $2 \cdot 8$ & $19 \cdot 8$ \\
\hline,$\quad 21$ & $15 \cdot 9$ & $42 \cdot 0$ & $0 \cdot 010$ & $0 \cdot 8$ & $5 \cdot 0$ & $38 \cdot 3$ & $7 \cdot 7$ & 14 & $2 \cdot 74$ & $13 \cdot 5$ & 146 & $3 \cdot 6$ & $24 \cdot 8$ \\
\hline Aug. 6 & $16 \cdot 5$ & $45 \cdot 7$ & 0.010 & $0 \cdot 6$ & $3 \cdot 7$ & $37 \cdot 9$ & $10 \cdot 2$ & 16 & $2 \cdot 37$ & $8 \cdot 8$ & 184 & $4 \cdot 2$ & $28 \cdot 5$ \\
\hline,$\quad 21$ & $16 \cdot 5$ & $47 \cdot 5$ & $0 \cdot 011$ & nil & 1.8 & $16 \cdot 4$ & $9 \cdot 1$ & 15 & $1 \cdot 09$ & $3 \cdot 9$ & 201 & $4 \cdot 2$ & $30 \cdot 3$ \\
\hline Sept. 5 & $16 \cdot 5$ & $43 \cdot 8$ & 0.010 & nil & $-3 \cdot 7$ & $11 \cdot 3$ & - & 15 & $0 \cdot 75$ & - & 212 & $4 \cdot 2$ & $26 \cdot 6$ \\
\hline , 20 & $16 \cdot 4$ & $44 \cdot 3$ & $0 \cdot 010$ & $-0 \cdot 1$ & $0 \cdot 5$ & $11 \cdot 3$ & $22 \cdot 6$ & 15 & $0 \cdot 75$ & $1 \cdot 1$ & 232 & $4 \cdot 1$ & $27 \cdot 1$ \\
\hline Oct. 6 & $16 \cdot 6$ & $39 \cdot 1$ & $0 \cdot 009$ & $0 \cdot 2$ & $5 \cdot 2$ & $32 \cdot 7$ & - & 16 & $2 \cdot 04$ & - & 256 & $4 \cdot 3$ & $21 \cdot 9$ \\
\hline
\end{tabular}

TABle 27: B6.

\begin{tabular}{|c|c|c|c|c|c|c|c|c|c|c|c|c|c|}
\hline May 12 & $14 \cdot 3$ & $27 \cdot 5$ & $0 \cdot 009$ & - & - & - & - & - & - & - & - & - & - \\
\hline,$\quad 26$ & $14 \cdot 4$ & $28 \cdot 0$ & 0.009 & $0 \cdot 1$ & $0 \cdot 5$ & $14 \cdot 5$ & $29 \cdot 0$ & 14 & $1 \cdot 04$ & $1 \cdot 8$ & 14 & $0 \cdot 1$ & 0.5 \\
\hline June ? & $14 \cdot 5$ & $31 \cdot 3$ & 0.010 & $0 \cdot 1$ & $3 \cdot 3$ & $26 \cdot 3$ & $8 \cdot 0$ & 14 & $1 \cdot 88$ & $11 \cdot 8$ & 41 & 0.2 & 3.8 \\
\hline, 2 & 15.0 & $34 \cdot 0$ & 0.010 & 0.5 & $2 \cdot 7$ & $31 \cdot 5$ & $11 \cdot 7$ & 14 & $2 \cdot 25$ & $8 \cdot 6$ & 72 & 0.7 & 6.5 \\
\hline July & $15 \cdot 2$ & $37 \cdot 2$ & 0.011 & $0 \cdot 2$ & $3 \cdot 2$ & $27 \cdot 7$ & $8 \cdot 7$ & 14 & 1.98 & $9 \cdot 4$ & 100 & 0.9 & $9 \cdot 7$ \\
\hline,$\quad 21$ & $15 \cdot 7$ & $42 \cdot 5$ & 0.011 & 0.5 & $5 \cdot 3$ & $31 \cdot 8$ & $6 \cdot 0$ & 14 & $2 \cdot 28$ & $14 \cdot 3$ & 132 & $1 \cdot 4$ & $15 \cdot 0$ \\
\hline Aug. & $16 \cdot 2$ & $46 \cdot 0$ & 0.011 & 0.5 & $3 \cdot 5$ & 35.9 & $10 \cdot 3$ & 16 & $2 \cdot 24$ & $8 \cdot 2$ & 168 & 1.9 & $18 \cdot 5$ \\
\hline,$\quad 2$ & $16 \cdot 4$ & $48 \cdot 5$ & 0.011 & $0 \cdot 2$ & $2 \cdot 5$ & $24 \cdot 0$ & $9 \cdot 6$ & 15 & $1 \cdot 60$ & $5 \cdot 4$ & 192 & $2 \cdot 1$ & $21 \cdot 0$ \\
\hline Sept. & $16 \cdot 5$ & $48 \cdot 2$ & 0.011 & $0 \cdot 1$ & $-0 \cdot 3$ & $27 \cdot 6$ & - & 15 & $1 \cdot 84$ & - & 219 & $2 \cdot 2$ & $20 \cdot 7$ \\
\hline,$\quad 20$ & $16 \cdot 4$ & $45 \cdot 6$ & 0.010 & $-0 \cdot 1$ & $-2 \cdot 6$ & $13 \cdot 8$ & - & 15 & 0.92 & - & 233 & $2 \cdot 1$ & $18 \cdot 1$ \\
\hline
\end{tabular}


TABLE 28.

Summarised Data Concerning Maximum Requirements and Growth in Male and Female (M) Plaice.

\begin{tabular}{|c|c|c|c|c|c|c|c|c|c|c|c|c|c|}
\hline \multirow{2}{*}{$\begin{array}{l}\text { Fish } \\
\text { No. }\end{array}$} & \multirow[t]{2}{*}{ Sex. } & \multicolumn{2}{|c|}{$\begin{array}{c}\text { Initial } \\
\text { size. }\end{array}$} & \multicolumn{2}{|c|}{$\begin{array}{l}\text { Final } \\
\text { size. }\end{array}$} & \multicolumn{2}{|c|}{ Growth. } & \multicolumn{2}{|c|}{ Period. } & \multirow{2}{*}{$\begin{array}{c}\text { Days } \\
\text { in } \\
\text { Period. }\end{array}$} & \multirow{2}{*}{$\begin{array}{l}\text { Total } \\
\text { food } \\
\text { per the } \\
\text { period. } \\
\text { (gm.) }\end{array}$} & \multirow{2}{*}{$\begin{array}{c}\text { Average } \\
\text { weight } \\
\text { of food } \\
\text { per day } \\
\text { for the } \\
\text { period. } \\
\text { (gm.) }\end{array}$} & \multirow{2}{*}{$\begin{array}{l}\mathrm{Gm} \text {. of } \\
\text { food per } \\
1 \cdot 0 \mathrm{gm} \text {. } \\
\text { increase } \\
\text { in weight } \\
\text { of fish. }\end{array}$} \\
\hline & & $\begin{array}{l}\text { Lth. } \\
\text { (cm.) }\end{array}$ & $\begin{array}{c}\text { Wt. } \\
\text { (gm.) }\end{array}$ & $\begin{array}{l}\text { Lth. } \\
\text { (cm.) }\end{array}$ & $\begin{array}{l}\text { Wt. } \\
\text { (gm.) }\end{array}$ & $\begin{array}{l}\text { Lth. } \\
\text { (cm.) }\end{array}$ & $\begin{array}{l}\text { Wt. } \\
\text { (gm.) }\end{array}$ & From & To & & & & \\
\hline M1 & t & $15 \cdot 4$ & $34 \cdot 0$ & $21 \cdot 3$ & $117 \cdot 7$ & $5 \cdot 9$ & $83 \cdot 7$ & $12: 5$ & $6: 11$ & 178 & 987 & $5 \cdot 5$ & $11 \cdot 8$ \\
\hline M2 & ot & $15 \cdot 0$ & $33 \cdot 7$ & $19 \cdot 6$ & $79 \cdot 7$ & $4 \cdot 6$ & $46 \cdot 0$ & $2: 6$ & $6: 11$ & 157 & 655 & $4 \cdot 1$ & $14 \cdot 7$ \\
\hline M3 & 우 & $15 \cdot 0$ & $35 \cdot 0$ & $19 \cdot 4$ & $82 \cdot 4$ & $4 \cdot 4$ & $47 \cdot 4$ & $14: 5$ & $6: 11$ & 176 & 900 & $5 \cdot 1$ & $19 \cdot 0$ \\
\hline M4 & 오 & $13 \cdot 4$ & $23 \cdot 3$ & $17 \cdot 6$ & $59 \cdot 2$ & $4 \cdot 2$ & $35 \cdot 9$ & $14: 5$ & $6: 11$ & 176 & 778 & $4 \cdot 4$ & $21 \cdot 7$ \\
\hline
\end{tabular}


TABLES 29 AND 30 .

Maximum Requirements and Growth of Male (M) Plaice.

Table 29: M1.

\begin{tabular}{|c|c|c|c|c|c|c|c|c|c|c|c|c|c|}
\hline \multirow{2}{*}{$\begin{array}{l}\text { Date. } \\
\text { (1930) }\end{array}$} & \multicolumn{2}{|c|}{$\begin{array}{l}\text { Size } \\
\text { of } \\
\text { flsh. }\end{array}$} & \multirow[t]{2}{*}{ Wt./Lth. } & $\begin{array}{r}\text { Gro } \\
\text { De } \\
\text { peri }\end{array}$ & $\begin{array}{l}\text { wth } \\
\text { od. } \\
\text { od. }\end{array}$ & \multirow{2}{*}{$\begin{array}{c}\text { Total } \\
\text { food } \\
\text { per } \\
\text { period. } \\
\text { (gm.) }\end{array}$} & \multirow[t]{2}{*}{$\begin{array}{c}\mathrm{Gm} . \text { of } \\
\text { food } \\
\text { per } \\
1.0 \mathrm{gm} \text {. } \\
\text { increase } \\
\text { in } \\
\text { weight } \\
\text { of fish. }\end{array}$} & \multirow[t]{2}{*}{$\begin{array}{c}\text { No. of } \\
\text { days } \\
\text { in } \\
\text { period. }\end{array}$} & \multirow{2}{*}{$\begin{array}{c}\text { Average } \\
\text { food } \\
\text { per day } \\
\text { during } \\
\text { each } \\
\text { perind. } \\
\text { (gm.) }\end{array}$} & \multirow{2}{*}{$\begin{array}{l}\text { Percent- } \\
\text { age } \\
\text { growth } \\
\text { in wt. }\end{array}$} & \multirow{2}{*}{$\begin{array}{l}\text { Total } \\
\text { food } \\
\text { to date } \\
\text { (gm.) }\end{array}$} & \multicolumn{2}{|c|}{$\begin{array}{l}\text { Cumulative } \\
\text { growth. }\end{array}$} \\
\hline & $\begin{array}{l}\text { Lth. } \\
\text { (cm.) }\end{array}$ & $\begin{array}{l}\text { Wt. } \\
\text { (gm.) }\end{array}$ & & $\begin{array}{l}\text { Lth. } \\
\text { (em) }\end{array}$ & $\underset{\text { (gm.) }}{\text { Wt. }}$ & & & & & & & $\begin{array}{l}\text { Ith. } \\
\text { (em.) }\end{array}$ & $\begin{array}{l}\text { Wt. } \\
\text { (gm.) }\end{array}$ \\
\hline May 12 & $15 \cdot 4$ & $34 \cdot 0$ & $0 \cdot 009$ & - & - & - & - & - & - & - & - & - & - \\
\hline & $15 \cdot 8$ & $41 \cdot 5$ & $0 \cdot 009$ & 0.4 & $7 \cdot 5$ & $50 \cdot 2$ & $6 \cdot 7$ & 14 & $3 \cdot 6$ & $22 \cdot 1$ & 50 & 0.4 & $7 \cdot 5$ \\
\hline June 9 & $16 \cdot 8$ & $49 \cdot 8$ & 0.010 & $1 \cdot 0$ & $8 \cdot 3$ & $64 \cdot 1$ & $7 \cdot 7$ & 14 & $4 \cdot 6$ & $20 \cdot 0$ & 114 & $1 \cdot 4$ & 15.8 \\
\hline ,, 23 & $17 \cdot 0$ & $50 \cdot 7$ & 0.010 & $0 \cdot 2$ & 0.9 & $65 \cdot 6$ & $72 \cdot 9$ & 14 & $4 \cdot 7$ & $1 \cdot 8$ & 180 & $1 \cdot 6$ & 16.7 \\
\hline July 7 & $17 \cdot 5$ & $61 \cdot 0$ & 0.011 & $0 . \overline{5}$ & $10 \cdot 3$ & $157 \cdot 6$ & $15 \cdot 3$ & 14 & $11 \cdot 2$ & $20 \cdot 3$ & 337 & $2 \cdot 1$ & $27 \cdot 0$ \\
\hline,$\quad 21$ & $17 \cdot 9$ & $65 \cdot 0$ & 0.011 & 0.4 & $4 \cdot 0$ & $81 \cdot 4$ & $20 \cdot 4$ & 14 & $5 \cdot 8$ & $6 \cdot 6$ & 419 & $2 \cdot 5$ & $31 \cdot 0$ \\
\hline Aug. 6 & $18 \cdot 5$ & $74 \cdot 0$ & 0.012 & 0.6 & $9 \cdot 0$ & $76 \cdot 4$ & $8 \cdot 5$ & 16 & $4 \cdot 8$ & $13 \cdot 8$ & 495 & $3 \cdot 1$ & $40 \cdot 0$ \\
\hline,$\quad 21$ & $19 \cdot 3$ & $85 \cdot 0$ & 0.012 & 0.8 & $11 \cdot 0$ & $82 \cdot 5$ & $7 \cdot 5$ & 15 & $5 \cdot 5$ & $14 \cdot 9$ & 578 & $3 \cdot 9$ & $51 \cdot 0$ \\
\hline Sept. 20 & $20 \cdot 0$ & $89 \cdot 6$ & $0 \cdot 011$ & 0.7 & $4 \cdot 6$ & $142 \cdot 5$ & $31 \cdot 0$ & 30 & $4 \cdot 7$ & $2 x$ & 720 & $4 \cdot 6$ & $55 \cdot 6$ \\
\hline Oct. 6 & $20 \cdot 4$ & $102 \cdot 2$ & 0.012 & 0.4 & $12 \cdot 6$ & $92 \cdot 0$ & $7 \cdot 3$ & 16 & $5 \cdot 8$ & $14 \cdot 1$ & 812 & 5. & $68 \cdot 2$ \\
\hline,$\quad 23$ & $20 \cdot 7$ & $102 \cdot 0$ & 0.012 & $0 \cdot 3$ & -0.2 & $91 \cdot 0$ & - & 17 & $5 \cdot 4$ & - & 903 & $5 \cdot 3$ & $68 \cdot 0$ \\
\hline Nov. 6 & $21 \cdot 3$ & $117 \cdot 7$ & 0.012 & 0.6 & $15 \cdot 7$ & $84 \cdot 0$ & $5 \cdot 4$ & 14 & $6 \cdot 0$ & $15 \cdot 4$ & 987 & 5.9 & $83 \cdot 7$ \\
\hline
\end{tabular}

Table 30: M2.

\begin{tabular}{|c|c|c|c|c|c|c|c|c|c|c|c|c|c|}
\hline June & $15 \cdot 0$ & $33 \cdot 7$ & 0.010 & - & - & - & - & - & - & - & - & - & \\
\hline, & $15 \cdot 0$ & $31 \cdot 9$ & 0.009 & nil & $-1 \cdot 8$ & $15 \cdot 7$ & - & 7 & $2 \cdot 2$ & - & 16 & nil & -1.8 \\
\hline,$\quad 23$ & $15 \cdot 1$ & $33 \cdot 4$ & 0.010 & $0 \cdot 1$ & $1 \cdot 5$ & $38 \cdot 2$ & $25 \cdot 4$ & 14 & $2 \cdot 7$ & $4 \cdot 7$ & 54 & $0 \cdot 1$ & -0.3 \\
\hline July 7 & $15 \cdot 5$ & $36 \cdot 0$ & 0.010 & 0.4 & $2 \cdot 6$ & $66 \cdot 3$ & $25 \cdot 5$ & 14 & $4 \cdot 7$ & $7 \cdot 8$ & 120 & 0.5 & $2 \cdot 3$ \\
\hline,$\quad 21$ & $15 \cdot 7$ & $40 \cdot 0$ & 0.010 & $0 \cdot 2$ & $4 \cdot 0$ & $56 \cdot 7$ & $14 \cdot 2$ & 14 & $4 \cdot 1$ & $11 \cdot 1$ & 177 & 0.7 & $6 \cdot 3$ \\
\hline Aug. 6 & $16 \cdot 4$ & $44 \cdot 7$ & 0.010 & $0 \cdot 7$ & $4 \cdot 7$ & $69 \cdot 2$ & $14 \cdot 7$ & 16 & $4 \cdot 3$ & $11 \cdot 7$ & 246 & $1 \cdot 4$ & $11 \cdot 0$ \\
\hline ," 21 & $16 \cdot 9$ & $49 \cdot 0$ & 0.010 & $0 \cdot 5$ & $4 \cdot 3$ & $60 \cdot 0$ & $14 \cdot 0$ & 15 & $4 \cdot 0$ & $9 \cdot 2$ & 306 & $1 \cdot 9$ & $15 \cdot 3$ \\
\hline Sept. 20 & $17 \cdot 8$ & $57 \cdot 4$ & 0.010 & 0.9 & $8 \cdot 4$ & $111 \cdot 8$ & $13 \cdot 3$ & 30 & $3 \cdot 7$ & $2 \mathrm{x}$ & 418 & $2 \cdot 8$ & $23 \cdot 7$ \\
\hline Oct. 6 & $18 \cdot 3$ & $62 \cdot 2$ & 0.010 & 0.5 & $4 \cdot 8$ & $86 \cdot 4-$ & $18 \cdot 0$ & 16 & $5 \cdot 4-$ & $8 \cdot 4$ & 504 & $3 \cdot 3$ & $28 \cdot 5$ \\
\hline,$\quad 23$ & $19 \cdot 0$ & $71 \cdot 4$ & 0.010 & 0.7 & $9 \cdot 2$ & $78 \cdot 0$ & $8 \cdot 5$ & 17 & $4 \cdot 6$ & $14 \cdot 8$ & 582 & $4 \cdot 0$ & $37 \cdot 7$ \\
\hline Nov. 6 & $19 \cdot 6$ & $79 \cdot 7$ & 0.011 & 0.6 & $8 \cdot 3$ & $72 \cdot 0$ & 8.7 & 14 & $5 \cdot 1$ & $11 \cdot 6$ & 654 & $4 \cdot 6$ & $46 \cdot 0$ \\
\hline
\end{tabular}


TABLES 31 AND 32.

Maximum Requirements and Growth of Female (M) Plaice.

TAble 31: M3.

\begin{tabular}{|c|c|c|c|c|c|c|c|c|c|c|c|c|c|}
\hline \multirow{2}{*}{$\begin{array}{l}\text { Date. } \\
\text { (1930) }\end{array}$} & \multicolumn{2}{|c|}{$\begin{array}{l}\text { Size } \\
\text { of } \\
\text { fish. }\end{array}$} & \multirow[t]{2}{*}{$\begin{array}{l}\text { Wt./ } \\
\text { Lth. }\end{array}$} & \multicolumn{2}{|c|}{$\begin{array}{l}\text { Growth } \\
\text { per } \\
\text { period. }\end{array}$} & \multirow{2}{*}{$\begin{array}{c}\text { Total } \\
\text { food } \\
\text { per } \\
\text { period. } \\
\text { (gm.) }\end{array}$} & \multirow[t]{2}{*}{$\begin{array}{c}\text { Gm. of } \\
\text { food } \\
\text { per } \\
1.0 \mathrm{gm} . \\
\text { increase } \\
\text { in } \\
\text { weight } \\
\text { of fish. }\end{array}$} & \multirow{2}{*}{$\begin{array}{c}\text { No. of } \\
\text { days } \\
\text { in } \\
\text { period. }\end{array}$} & \multirow{2}{*}{$\begin{array}{l}\text { Average } \\
\text { food } \\
\text { per day } \\
\text { during } \\
\text { each } \\
\text { period. } \\
\text { (gm.) }\end{array}$} & \multirow{2}{*}{$\begin{array}{l}\text { Percent- } \\
\text { age } \\
\text { growth } \\
\text { in wt. } \\
\end{array}$} & \multirow{2}{*}{$\begin{array}{c}\text { Total } \\
\text { food } \\
\text { to date } \\
\\
(\mathrm{gm} .)\end{array}$} & \multicolumn{2}{|c|}{$\begin{array}{l}\text { Cumulative } \\
\text { growth. }\end{array}$} \\
\hline & $\begin{array}{l}\text { Lth. } \\
\text { (cm.) }\end{array}$ & $\begin{array}{l}\text { Wt. } \\
\text { (gm.) }\end{array}$ & & $\begin{array}{l}\text { Lth. } \\
\text { (em.) }\end{array}$ & $\begin{array}{l}\text { Wt. } \\
\text { (gm.) }\end{array}$ & & & & & & & $\begin{array}{l}\text { Lth. } \\
(\mathrm{cm} .)\end{array}$ & $\begin{array}{l}\text { Wt. } \\
(\mathrm{gm} .)\end{array}$ \\
\hline May 14 & $15 \cdot 0$ & $35 \cdot 0$ & $0 \cdot 010$ & - & - & - & - & - & - & - & - & - & - \\
\hline,,$\quad 26$ & $15 \cdot 1$ & $34 \cdot 8$ & 0.010 & $0 \cdot 1$ & -0.2 & $36 \cdot 0$ & - & 12 & $3 \cdot 0$ & - & 36 & $0 \cdot 1$ & $-0 \cdot 2$ \\
\hline June 9 & $15 \cdot 5$ & $39 \cdot 8$ & 0.011 & $0 \cdot 4$ & $5 \cdot 0$ & $55 \cdot 7$ & $11 \cdot 1$ & 14 & $4 \cdot 0$ & $14 \cdot 4$ & 92 & $0 \cdot 5$ & $4 \cdot 8$ \\
\hline ,, 23 & $16 \cdot 4$ & $48 \cdot 8$ & 0.011 & 0.9 & $9 \cdot 0$ & $75 \cdot 6$ & $8 \cdot 4$ & 14 & $5 \cdot 4$ & $22 \cdot 6$ & 167 & $1 \cdot 4$ & $13 \cdot 8$ \\
\hline July 7 & $16 \cdot 8$ & $51 \cdot 2$ & 0.011 & $0 \cdot 4$ & $2 \cdot 4$ & 153.9 & $64 \cdot 1$ & 14 & $11 \cdot 0$ & $4 \cdot 9$ & 321 & 1.8 & $16 \cdot 2$ \\
\hline,,$\quad 21$ & $17 \cdot 2$ & $59 \cdot 0$ & 0.011 & 0.4 & $7 \cdot 8$ & $83 \cdot 9$ & $10 \cdot 8$ & 14 & $6 \cdot 0$ & $15 \cdot 2$ & 405 & $2 \cdot 2$ & $24 \cdot 0$ \\
\hline Aug. 6 & $17 \cdot 6$ & $61 \cdot 0$ & 0.011 & $0 \cdot 4$ & $2 \cdot 0$ & $73 \cdot 7$ & $36 \cdot 8$ & 16 & $4 \cdot 6$ & $3 \cdot 4$ & 479 & $2 \cdot 6$ & $26 \cdot 0$ \\
\hline,,$\quad 21$ & $18 \cdot 0$ & $65 \cdot 0$ & 0.011 & 0.4 & $4 \cdot 0$ & $63 \cdot 5$ & $15 \cdot 9$ & 15 & $4 \cdot 2$ & $6 \cdot 6$ & 542 & $3 \cdot 0$ & $30 \cdot 0$ \\
\hline Sept. 20 & $18 \cdot 6$ & $69 \cdot 6$ & 0.011 & 0.6 & $4 \cdot 6$ & $119 \cdot 3$ & $25 \cdot 9$ & 30 & $4 \cdot 0$ & $2 \mathrm{x}$ & 662 & $3 \cdot 6$ & $34 \cdot 6$ \\
\hline Oct. 6 & $18 \cdot 8$ & $74 \cdot 0$ & 0.011 & $0 \cdot 2$ & $4 \cdot 4$ & $88-$ & $20 \cdot 0$ & 16 & $5 \cdot 5$ & $6 \cdot 3$ & 750 & $3 \cdot 8$ & $39 \cdot 0$ \\
\hline, $2 \quad 23$ & $19 \cdot 0$ & $76 \cdot 2$ & 0.01 & $0 . \overline{2}$ & $2 \cdot 2$ & $78 \cdot 0$ & $35 \cdot 5$ & 17 & $4 \cdot 6$ & $3 \cdot 0$ & 828 & $4 \cdot 0$ & $41 \cdot 2$ \\
\hline Nov. 6 & $19 \cdot 4$ & $82 \cdot 4$ & 0.011 & $0 \cdot 4$ & $6 \cdot 2$ & $72 \cdot 0$ & $11 \cdot 6$ & 14 & $5 \cdot 1$ & $8 \cdot 1$ & 900 & $4 \cdot 4$ & $47 \cdot 4$ \\
\hline
\end{tabular}

TABLE 32: M4.

\begin{tabular}{|c|c|c|c|c|c|c|c|c|c|c|c|c|c|}
\hline May 14 & $13 \cdot 4$ & $23 \cdot 3$ & 0.010 & - & 一 & - & - & - & - & - & - & - & - \\
\hline & $13 \cdot 6$ & $25 \cdot 2$ & 0.010 & $0 \cdot 2$ & $1 \cdot 9$ & $39 \cdot 0$ & $20 \cdot 5$ & 12 & $3 \cdot 2$ & $8 \cdot 1$ & 39 & $0 \cdot 2$ & $1 \cdot 9$ \\
\hline June 9 & $14 \cdot 2$ & 28.0 & 0.010 & 0.6 & $2 \cdot 8$ & $57 \cdot 4$ & $20 \cdot 5$ & 14 & $4 \cdot 1$ & $11 \cdot 1$ & 96 & 0.8 & $4 \cdot 7$ \\
\hline,,$\quad 23$ & $14 \cdot 3$ & $28 \cdot 7$ & 0.010 & $0 \cdot 1$ & 0.7 & $72 \cdot 3$ & $103 \cdot 3$ & 14 & $5 \cdot 2$ & $2 \cdot 5$ & 169 & 0.9 & $5 \cdot 4$ \\
\hline July 7 & $14 \cdot 7$ & $31 \cdot 8$ & 0.010 & $0 \cdot 4$ & $3 \cdot 1$ & $70 \cdot 6$ & $22 \cdot 8$ & 14 & $5 \cdot 0$ & $10 \cdot 8$ & 239 & $1 \cdot 3$ & $8 \cdot 5$ \\
\hline,$\quad 21$ & $15 \cdot 0$ & $36 \cdot 5$ & 0.010 & $0 \cdot 3$ & $4 \cdot 7$ & $54 \cdot 5$ & $11 \cdot 6$ & 14 & $3 \cdot 9$ & $14 \cdot 8$ & 294 & $1 \cdot 6$ & $13 \cdot 2$ \\
\hline Aug. $\quad 6$ & $15 \cdot 1$ & $36 \cdot 0$ & 0.010 & $0 \cdot 1$ & -0.5 & $60 \cdot 4$ & - & 16 & $3 \cdot 8$ & - & 354 & $1 \cdot 7$ & $12 \cdot 7$ \\
\hline,$\quad 21$ & $15 \cdot 8$ & $44 \cdot 2$ & 0.010 & $0 \cdot 7$ & $8 \cdot 2$ & $68 \cdot 5$ & $8 \cdot 4$ & 15 & $4 \cdot 6$ & $22 \cdot 8$ & 423 & $2 \cdot 4$ & $20 \cdot 9$ \\
\hline Sept. 20 & $16 \cdot 8$ & $50 \cdot 6$ & 0.011 & $1 \cdot 0$ & $6 \cdot 4$ & $117 \cdot 5$ & $18 \cdot 4$ & 30 & $3 \cdot 9$ & $2 x$ & 540 & $3 \cdot 4$ & $27 \cdot 3$ \\
\hline Oct. $\quad 6$ & $17 \cdot 0$ & $52 \cdot 6$ & 0.011 & $0 \cdot 2$ & $2 \cdot 0$ & $87 \cdot 5-$ & $43 \cdot 7$ & 16 & $5 \cdot 5$ & $4 \cdot 0$ & 628 & $3 \cdot 6$ & $29 \cdot 3$ \\
\hline,$\quad 23$ & $17 \cdot 3$ & $54 \cdot 2$ & 0.011 & $0 \cdot 3$ & $1 \cdot 6$ & $78 \cdot 0$ & $48 \cdot 7$ & 17 & $4 \cdot 6$ & $3 \cdot 0$ & 706 & $3 \cdot 9$ & $30 \cdot 9$ \\
\hline Nov. 6 & $17 \cdot 6$ & $59 \cdot 2$ & 0.011 & $0 \cdot 3$ & $5 \cdot 0$ & $72 \cdot 8$ & $14 \cdot 6$ & 14 & $5 \cdot 2$ & $9 \cdot 2$ & 778 & $4 \cdot 2$ & 35.9 \\
\hline
\end{tabular}


TABLE 33 .

Summarised Data Concerning Growth and Intermediate Food Supplies in Male and Female (I) Plaice.

\begin{tabular}{|c|c|c|c|c|c|c|c|c|c|c|c|c|c|}
\hline \multirow{2}{*}{$\begin{array}{l}\text { Fish } \\
\text { No. }\end{array}$} & \multirow[t]{2}{*}{ Sex. } & \multicolumn{2}{|c|}{$\begin{array}{c}\text { Initial } \\
\text { size. }\end{array}$} & \multicolumn{2}{|c|}{$\begin{array}{l}\text { Final } \\
\text { size. }\end{array}$} & \multicolumn{2}{|c|}{ Growth. } & \multicolumn{2}{|c|}{ Period. } & \multirow{2}{*}{$\begin{array}{c}\text { Days } \\
\text { in } \\
\text { Period. }\end{array}$} & \multirow{2}{*}{$\begin{array}{l}\text { Total } \\
\text { food } \\
\text { per the } \\
\text { period. } \\
\text { (gm.) }\end{array}$} & \multirow{2}{*}{$\begin{array}{l}\text { Average } \\
\text { weight } \\
\text { of food } \\
\text { per day } \\
\text { for the } \\
\text { period. } \\
\text { (gm.) }\end{array}$} & \multirow{2}{*}{$\begin{array}{l}\text { Gm. of } \\
\text { food per } \\
1 \cdot 0 \mathrm{gm} \text {. } \\
\text { increase } \\
\text { in weight } \\
\text { of fish. }\end{array}$} \\
\hline & & $\begin{array}{l}\text { Lth. } \\
\text { (cm.) }\end{array}$ & $\begin{array}{l}\text { Wt. } \\
\text { (gm.) }\end{array}$ & $\begin{array}{l}\text { Lth. } \\
\text { (cm.) }\end{array}$ & $\begin{array}{l}\text { Wt. } \\
\text { (gm.) }\end{array}$ & $\begin{array}{l}\text { Lth. } \\
(\mathrm{cm} .)\end{array}$ & $\begin{array}{l}\text { Wt. } \\
\text { (gm.) }\end{array}$ & From & To & & & & \\
\hline I1 & $\widehat{0}$ & $15 \cdot 7$ & $33 \cdot 7$ & $19 \cdot 2$ & $65 \cdot 7$ & $3 \cdot 5$ & $32 \cdot 0$ & $13: 6$ & $6: 11$ & 146 & 217 & $1 \cdot 5$ & $6 \cdot 8$ \\
\hline I 2 & $\hat{\sigma}$ & $15 \cdot 0$ & $32 \cdot 0$ & $17 \cdot 6$ & $56 \cdot 0$ & $2 \cdot 6$ & $24 \cdot 0$ & $12: 5$ & $6: 11$ & 178 & 252 & $1 \cdot 4$ & $10 \cdot 5$ \\
\hline I3 & 우 & $12 \cdot 8$ & $20 \cdot 3$ & $17 \cdot 6$ & $59 \cdot 5$ & $4 \cdot 8$ & $39 \cdot 2$ & $14: 5$ & $6: 11$ & 176 & 247 & $1 \cdot 4$ & $6 \cdot 3$ \\
\hline I4 & 오 & $14 \cdot 9$ & $32 \cdot 0$ & $18 \cdot 3$ & $67 \cdot 4$ & $3 \cdot 4$ & $35 \cdot 4$ & $18: 6$ & $6: 11$ & 141 & 208 & 1.5 & $5 \cdot 9$ \\
\hline
\end{tabular}


TABLES 34 AND 35 .

\section{Intermediate Rations and Growth of Male (I) Plaice.}

TABLE 34: I1.

\begin{tabular}{|c|c|c|c|c|c|c|c|c|c|c|c|c|c|}
\hline \multirow{2}{*}{$\begin{array}{l}\text { Date. } \\
\text { (1930) }\end{array}$} & \multicolumn{2}{|c|}{$\begin{array}{l}\text { Size } \\
\text { of } \\
\text { flsh. }\end{array}$} & \multirow[t]{2}{*}{ Wt./Lth. } & \multicolumn{2}{|c|}{$\begin{array}{l}\text { Growth } \\
\text { per } \\
\text { period. }\end{array}$} & \multirow{2}{*}{$\begin{array}{c}\text { Total } \\
\text { food } \\
\text { per } \\
\text { period. } \\
\text { (gm.) }\end{array}$} & \multirow[t]{2}{*}{$\begin{array}{l}\text { Gm. of } \\
\text { food } \\
\text { per } \\
1.0 \mathrm{gm} \text {. } \\
\text { increase } \\
\text { in } \\
\text { weight } \\
\text { of fish. }\end{array}$} & \multirow[t]{2}{*}{$\begin{array}{l}\text { No. of } \\
\text { days } \\
\text { in } \\
\text { period. }\end{array}$} & \multirow{2}{*}{$\begin{array}{c}\text { Average } \\
\text { food } \\
\text { per day } \\
\text { during } \\
\text { each } \\
\text { period. } \\
\text { (gm.) }\end{array}$} & \multirow[t]{2}{*}{$\begin{array}{c}\text { Percent } \\
\text { age } \\
\text { growth } \\
\text { in wt. }\end{array}$} & \multirow{2}{*}{$\begin{array}{c}\text { Total } \\
\text { food } \\
\text { to date } \\
\\
\text { (gm.) }\end{array}$} & \multicolumn{2}{|c|}{$\begin{array}{l}\text { Cumulative } \\
\text { growth. }\end{array}$} \\
\hline & $\begin{array}{l}\text { Lth. } \\
\text { (cm.) }\end{array}$ & $\begin{array}{l}\text { Wt. } \\
\text { (gm.) }\end{array}$ & & $\begin{array}{l}\text { Lth. } \\
\text { (em.) }\end{array}$ & $\begin{array}{l}\text { Wt. } \\
\text { (gm.) }\end{array}$ & & & & & & & $\begin{array}{l}\text { Lth. } \\
\text { (cm.) }\end{array}$ & $\begin{array}{l}\text { Wt. } \\
\text { (gm.) }\end{array}$ \\
\hline June 13 & $15 \cdot 7$ & $33 \cdot 7$ & $0 \cdot 009$ & - & - & - & - & - & - & - & - & - & - \\
\hline & $15 \cdot 9$ & $36 \cdot 3$ & $0 \cdot 009$ & $0 \cdot 2$ & $2 \cdot 6$ & $12 \cdot 8$ & $4 \cdot 9$ & 10 & $1 \cdot 28$ & $7 \cdot 7$ & 13 & $0 \cdot 2$ & $2 \cdot 6$ \\
\hline July 7 & $16 \cdot 3$ & $39 \cdot 3$ & 0.009 & $0 \cdot 4$ & $3 \cdot 0$ & $14 \cdot 0$ & $4 \cdot 7$ & 14 & 1.00 & $8 \cdot 3$ & 27 & $0 \cdot 6$ & $5 \cdot 6$ \\
\hline ," 21 & $16 \cdot 5$ & $43 \cdot 5$ & $0 \cdot 009$ & $0 \cdot 2$ & $4 \cdot 2$ & $17 \cdot 6$ & $4 \cdot 2$ & 14 & $1 \cdot 26$ & $10 \cdot 7$ & 44 & $0 \cdot 8$ & $9 \cdot 8$ \\
\hline Aug. 6 & $17 \cdot 1$ & $48 \cdot 0$ & $0 \cdot 009$ & 0.6 & $4 \cdot 5$ & $26 \cdot 0$ & $5 \cdot 8$ & 16 & $1 \cdot 62$ & $10 \cdot 3$ & 70 & $1 \cdot 4$ & $14 \cdot 3$ \\
\hline,$\quad 21$ & $17 \cdot 7$ & $52 \cdot 0$ & 0.009 & $0 \cdot 6$ & $4 \cdot 0$ & $24 \cdot 0$ & $6 \cdot 0$ & 15 & $1 \cdot 60$ & $8 \cdot 3$ & 94 & $2 \cdot 0$ & $18 \cdot 3$ \\
\hline Sept. 19 & $18 \cdot 2$ & $57 \cdot 6$ & 0.010 & 0.5 & $5 \cdot 6$ & $48 \cdot 0$ & $8 \cdot 6$ & 29 & $1 \cdot 66$ & $2 x$ & 142 & $2 \cdot 5$ & $23 \cdot 9$ \\
\hline Oct. 6 & $18 \cdot 8$ & $64 \cdot 3$ & $0 \cdot 010$ & $0 \cdot 6$ & $6 \cdot 7$ & $32 \cdot 0$ & $4 \cdot 8$ & 17 & $1 \cdot 88$ & $11 \cdot 6$ & 174 & $3 \cdot 1$ & $30 \cdot 6$ \\
\hline,,$\quad 23$ & $19 \cdot 1$ & $64 \cdot 7$ & 0.010 & $0 \cdot 3$ & $0 \cdot 4$ & $25 \cdot 0$ & $62 \cdot 5$ & 17 & $1 \cdot 47$ & $0 \cdot 6$ & 199 & $3 \cdot 4$ & $31 \cdot 0$ \\
\hline Nov. 6 & $19 \cdot 2$ & $65 \cdot 7$ & $0 \cdot 010$ & $0 \cdot 1$ & $1 \cdot 0$ & $18 \cdot 0$ & $18 \cdot 0$ & 14 & $1 \cdot 29$ & 1.5 & 217 & $3 \cdot 5$ & $32 \cdot 0$ \\
\hline
\end{tabular}

TABLE 35: I2.

\begin{tabular}{|c|c|c|c|c|c|c|c|c|c|c|c|c|c|}
\hline May 12 & $15 \cdot 0$ & $32 \cdot 0$ & $0 \cdot 009$ & - & - & - & 一 & 一 & - & - & - & - & - \\
\hline & $15 \cdot 2$ & $33 \cdot 7$ & 0.009 & $0 \cdot 2$ & $1 \cdot 7$ & $14 \cdot 7$ & $8 \cdot 6$ & 14 & 1.05 & $5 \cdot 3$ & 15 & $0 \cdot 2$ & $1 \cdot 7$ \\
\hline June 9 & $15 \cdot 2$ & $31 \cdot 0$ & $0 \cdot 009$ & nil & $2 \cdot 7$ & $13 \cdot 8$ & - & 14 & 0.99 & - & 28 & $0 \cdot 2$ & $-1 \cdot 0$ \\
\hline , $\quad 23$ & $15 \cdot 9$ & $38 \cdot 8$ & $0 \cdot 010$ & $0 \cdot 7$ & $7 \cdot 8$ & $13 \cdot 7$ & 1.8 & 14 & $0 \cdot 98$ & $25 \cdot I$ & 42 & $0 \cdot 9$ & $6 \cdot 8$ \\
\hline July & $16 \cdot 2$ & $39 \cdot 8$ & 0.010 & $0 \cdot 3$ & $1 \cdot 0$ & $14 \cdot 0$ & $14 \cdot 0$ & 14 & $1 \cdot 00$ & $2 \cdot 6$ & 56 & $1 \cdot 2$ & $7 \cdot 8$ \\
\hline,$\quad 21$ & $16 \cdot 2$ & $42 \cdot 0$ & 0.010 & nil & $2 \cdot 2$ & $16 \cdot 3$ & $7 \cdot 4$ & 14 & $1 \cdot 16$ & $5 \cdot 5$ & 72 & $1 \cdot 2$ & $10 \cdot 0$ \\
\hline Aug. 6 & $16 \cdot 3$ & $44 \cdot 0$ & 0.010 & $0 \cdot 1$ & $2 \cdot 0$ & $26 \cdot 0$ & $13 \cdot 0$ & 16 & $1 \cdot 62$ & $5 \cdot 0$ & 98 & $1 \cdot 3$ & $12 \cdot 0$ \\
\hline 21 & $16 \cdot 6$ & $46 \cdot 8$ & $0 \cdot 010$ & $0 \cdot 3$ & $2 \cdot 8$ & $23 \cdot 5$ & $8 \cdot 4$ & 15 & $1 \cdot 57$ & $6 \cdot 4$ & 122 & $1 \cdot 6$ & $14 \cdot 8$ \\
\hline Sept. 19 & $17 \cdot 1$ & $51 \cdot 0$ & $0 \cdot 010$ & $0 \cdot 5$ & $4 \cdot 2$ & $48 \cdot 0$ & $11 \cdot 4$ & 29 & $1 \cdot 70$ & $2 x$ & 170 & $2 \cdot 1$ & $19 \cdot 0$ \\
\hline 0 & $17 \cdot 4$ & $54 \cdot 6$ & $0 \cdot 010$ & $0 \cdot 3$ & $3 \cdot 6$ & $32 \cdot 0$ & $8 \cdot 9$ & 17 & $1 \cdot 88$ & $7 \cdot 1$ & 202 & $2 \cdot 4$ & $22 \cdot 6$ \\
\hline 23 & $17 \cdot 6$ & $55 \cdot 4$ & 0.010 & $0 \cdot 2$ & 0.8 & $25 \cdot 6$ & $32 \cdot 0$ & 17 & 1.51 & $1 \cdot 5$ & 228 & $2 \cdot 6$ & $23 \cdot 4$ \\
\hline 6 & & $6 \cdot 0$ & 0.010 & nil & $0 \cdot 6$ & $24 \cdot 2$ & $40 \cdot 3$ & 14 & $1 \cdot 73$ & $1 \cdot 1$ & 252 & $2 \cdot 6$ & $24 \cdot 0$ \\
\hline
\end{tabular}




\section{TABLES 36 AND 37.}

\section{Intermediate Rations and Growth of Female (I) Platce.}

TABLE $36:$ I3.

\begin{tabular}{|c|c|c|c|c|c|c|c|c|c|c|c|c|c|}
\hline \multirow{2}{*}{$\begin{array}{l}\text { Date. } \\
(1930)\end{array}$} & \multicolumn{2}{|c|}{$\begin{array}{l}\text { Size } \\
\text { of } \\
\text { fish. }\end{array}$} & \multirow[t]{2}{*}{$\begin{array}{l}\text { Wt./ } \\
\text { /Lth. }\end{array}$} & \multicolumn{2}{|c|}{$\begin{array}{l}\text { Growth } \\
\text { per } \\
\text { period. }\end{array}$} & \multirow{2}{*}{$\begin{array}{l}\text { Total } \\
\text { food } \\
\text { per } \\
\text { period. } \\
\text { (gm.) }\end{array}$} & \multirow[t]{2}{*}{$\begin{array}{l}\text { Gm. of } \\
\text { food } \\
\text { per } \\
1.0 \mathrm{gm} . \\
\text { increase } \\
\text { in } \\
\text { weight } \\
\text { of fish. }\end{array}$} & \multirow[t]{2}{*}{$\begin{array}{c}\text { No. of } \\
\text { days } \\
\text { in } \\
\text { period. }\end{array}$} & \multirow{2}{*}{$\begin{array}{l}\text { Average } \\
\text { food } \\
\text { per day } \\
\text { during } \\
\text { each } \\
\text { period. } \\
\text { (gm.) }\end{array}$} & \multirow[t]{2}{*}{$\begin{array}{l}\text { Percent- } \\
\text { age } \\
\text { growth } \\
\text { in wt. }\end{array}$} & \multirow{2}{*}{$\begin{array}{l}\text { Total } \\
\text { food } \\
\text { to date } \\
\\
\text { (gm.) }\end{array}$} & \multicolumn{2}{|c|}{$\begin{array}{l}\text { Cumulative } \\
\text { growth. }\end{array}$} \\
\hline & $\begin{array}{l}\text { Lth. } \\
\text { (cm.) }\end{array}$ & $\begin{array}{l}\text { Wt. } \\
\text { (gm.) }\end{array}$ & & $\begin{array}{l}\text { Lth. } \\
\text { (cm.) }\end{array}$ & $\begin{array}{l}\text { Wt. } \\
\text { (gm.) }\end{array}$ & & & & & & & $\begin{array}{l}\text { Lth. } \\
\text { (em.) }\end{array}$ & $\begin{array}{l}\text { Wt. } \\
\text { (gm.) }\end{array}$ \\
\hline May 14 & $12 \cdot 8$ & $20 \cdot 3$ & $0 \cdot 010$ & - & - & - & - & - & - & - & - & - & - \\
\hline , 26 & $12 \cdot 8$ & $21 \cdot 3$ & $0 \cdot 010$ & nil & $1 \cdot 0$ & $10 \cdot 9$ & $10 \cdot 9$ & 12 & $0 \cdot 91$ & $4 \cdot 9$ & 11 & nil & $1 \cdot 0$ \\
\hline June 9 & $13 \cdot 2$ & $23 \cdot 5$ & $0 \cdot 010$ & $0 \cdot 4$ & $2 \cdot 2$ & $11 \cdot 2$ & $5 \cdot 1$ & 14 & $0 \cdot 80$ & $10 \cdot 3$ & 22 & $0 \cdot 4$ & $3 \cdot 2$ \\
\hline , , 23 & $13 \cdot 7$ & $26 \cdot 0$ & $0 \cdot 010$ & $0 \cdot 5$ & $2 \cdot 5$ & $11 \cdot 2$ & $4 \cdot 5$ & 14 & $0 \cdot 80$ & $10 \cdot 6$ & 33 & $0 \cdot 9$ & $5 \cdot 7$ \\
\hline July 7 & $13 \cdot 9$ & $28 \cdot 0$ & 0.010 & $0 \cdot 2$ & $2 \cdot 0$ & $11 \cdot 2$ & $5 \cdot 6$ & 14 & $0 \cdot 80$ & $7 \cdot 7$ & 44 & $1 \cdot 1$ & $7 \cdot 7$ \\
\hline,$\quad 21$ & $14 \cdot 4$ & $32 \cdot 5$ & 0.011 & $0 \cdot 5$ & $4 \cdot 5$ & $17 \cdot 0$ & $3 \cdot 8$ & 14 & $1 \cdot 21$ & $16 \cdot 1$ & 61 & $1 \cdot 6$ & $12 \cdot 2$ \\
\hline Aug. 6 & $15 \cdot 0$ & $37 \cdot 8$ & $0 \cdot 011$ & $0 \cdot 6$ & $5 \cdot 3$ & $26 \cdot 0$ & $4 \cdot 9$ & 16 & $1 \cdot 62$ & $16 \cdot 3$ & 87 & $2 \cdot 2$ & $17 \cdot 5$ \\
\hline , 21 & $15 \cdot 7$ & $43 \cdot 0$ & 0.011 & $0 \cdot 7$ & $5 \cdot 2$ & $23 \cdot 5$ & $4 \cdot 5$ & 15 & $1 \cdot 57$ & $13 \cdot 8$ & 111 & $2 \cdot 9$ & $22 \cdot 7$ \\
\hline Sept. 19 & $16 \cdot 6$ & $50 \cdot 0$ & 0.011 & $0 \cdot 9$ & $7 \cdot 0$ & $48 \cdot 0$ & 6.9 & 29 & $1 \cdot 66$ & $2 \mathrm{x}$ & 159 & $3 \cdot 8$ & $29 \cdot 7$ \\
\hline Oet. 6 & $17 \cdot 1$ & $56 \cdot 1$ & $0 \cdot 011$ & 0.5 & $6 \cdot 1$ & $32 \cdot 0$ & $5 \cdot 2$ & 17 & $1 \cdot 88$ & $12 \cdot 2$ & 191 & $4 \cdot 3$ & $35 \cdot 8$ \\
\hline,$\quad 23$ & $17 \cdot 5$ & $58 \cdot 8$ & 0.011 & $0 \cdot 4$ & $2 \cdot 7$ & $28 \cdot 3$ & $10 \cdot 5$ & 17 & $1 \cdot 70$ & $4 \cdot 8$ & 219 & $4 \cdot 7$ & $38 \cdot 5$ \\
\hline Nov. 6 & $17 \cdot 6$ & $59 \cdot 5$ & 0.011 & $0 \cdot 1$ & 0.7 & $28 \cdot 0$ & $40 \cdot 0$ & 14 & $2 \cdot 00$ & $1 \cdot 2$ & 247 & $4 \cdot 8$ & $39 \cdot 2$ \\
\hline
\end{tabular}

TABLE $37:$ I4.

\begin{tabular}{|c|c|c|c|c|c|c|c|c|c|c|c|c|c|}
\hline June 18 & $14 \cdot 9$ & $32 \cdot 0$ & 0.010 & - & - & - & - & - & - & - & - & - & - \\
\hline & $14 \cdot 9$ & $30 \cdot 9$ & 0.010 & nil & $1 \cdot 1$ & $1 \cdot 7$ & - & 5 & $0 \cdot 34$ & - & 2 & nil & $-1 \cdot 1$ \\
\hline July 7 & $15 \cdot 1$ & $34 \cdot 0$ & 0.010 & $0 \cdot 2$ & $3 \cdot 1$ & $13 \cdot 9$ & $4 \cdot 5$ & 14 & 0.99 & $10 \cdot 0$ & 16 & $0 \cdot 2$ & $2 \cdot 0$ \\
\hline,$\quad 21$ & $15 \cdot 4$ & $39 \cdot 5$ & $0 \cdot 010$ & $0 \cdot 3$ & $5 \cdot 5$ & $17 \cdot 3$ & $3 \cdot 1$ & 14 & $1 \cdot 24$ & $16 \cdot 2$ & 33 & $0 \cdot 5$ & $7 \cdot 5$ \\
\hline Aug. 6 & $15 \cdot 9$ & $42 \cdot 0$ & 0.010 & 0.5 & $2 \cdot 5$ & $26 \cdot 0$ & $10 \cdot 4$ & 16 & 1.62 & $6 \cdot 3$ & 59 & $1 \cdot 0$ & $10 \cdot 0$ \\
\hline,$\quad 21$ & $16 \cdot 5$ & $48 \cdot 0$ & 0.010 & $0 \cdot 6$ & $6 \cdot 0$ & $24 \cdot 0$ & $4 \cdot 0$ & 15 & $1 \cdot 60$ & $14 \cdot 3$ & 83 & $1 \cdot 6$ & $16 \cdot 0$ \\
\hline Sept. 19 & $17 \cdot 2$ & $55 \cdot 3$ & 0.011 & 0.7 & $7 \cdot 3$ & $48 \cdot 0$ & $6 \cdot 6$ & 29 & $1 \cdot 66$ & $2 \mathrm{x}$ & 131 & $2 \cdot 3$ & $23 \cdot 3$ \\
\hline Oct. 6 & $17 \cdot 7$ & $62 \cdot 7$ & $0 \cdot 011$ & 0.5 & $7 \cdot 4$ & $30 \cdot 3$ & $4 \cdot 1$ & 17 & $1 \cdot 78$ & $13 \cdot 4$ & 161 & $2 \cdot 8$ & $30 \cdot 7$ \\
\hline 23 & $18 \cdot 1$ & $65 \cdot 3$ & 0.011 & $0 \cdot 4$ & $2 \cdot 6$ & $28 \cdot 2$ & $10 \cdot 8$ & 17 & $1 \cdot 66$ & $4 \cdot 1$ & 189 & $3 \cdot 2$ & $33 \cdot 3$ \\
\hline Nov. 6 & $18 \cdot 3$ & $67 \cdot 4$ & 0.011 & $0 \cdot 2$ & $2 \cdot 1$ & 18.5 & $8 \cdot 8$ & 14 & $1 \cdot 32$ & $3 \cdot 2$ & 208 & $3 \cdot 4$ & $35 \cdot 4$ \\
\hline
\end{tabular}


TABLES 38-41.

Data from January-AprIL Experiments on Maintenance (LyMPSTONE).

TABle 38: L1w (ð̋).

\begin{tabular}{|c|c|c|c|c|c|c|c|c|c|c|c|c|}
\hline \multirow[t]{2}{*}{$\begin{array}{c}\text { Date } \\
(1930)\end{array}$} & \multicolumn{2}{|c|}{$\begin{array}{c}\text { Size } \\
\text { of fish. }\end{array}$} & \multicolumn{2}{|c|}{$\begin{array}{l}\text { Growth } \\
\text { per } \\
\text { period. }\end{array}$} & \multirow{2}{*}{$\begin{array}{c}\text { Weight } \\
\text { of food } \\
\text { per } \\
\text { period. } \\
\text { (gm.) }\end{array}$} & \multirow[t]{2}{*}{$\begin{array}{c}\text { No. of } \\
\text { days } \\
\text { in } \\
\text { period. }\end{array}$} & \multirow{2}{*}{$\begin{array}{c}\text { Average } \\
\text { weight } \\
\text { of food } \\
\text { per day. } \\
\text { (gm.) }\end{array}$} & \multirow{2}{*}{$\begin{array}{c}\text { Ratio of } \\
\text { food per } \\
\text { day/ } \\
\text { /average } \\
\text { body-wt. } \\
\text { for } \\
\text { period. }\end{array}$} & \multirow{2}{*}{$\begin{array}{l}\text { Total } \\
\text { wt. of } \\
\text { food } \\
\text { to date. } \\
\text { (gm.) }\end{array}$} & \multirow{2}{*}{$\begin{array}{l}\text { No. of } \\
\text { days } \\
\text { since } \\
\text { com- } \\
\text { mence- } \\
\text { ment of } \\
\text { expt. }\end{array}$} & \multicolumn{2}{|c|}{$\begin{array}{c}\text { Cumulative } \\
\text { growth. }\end{array}$} \\
\hline & $\begin{array}{l}\text { Lth. } \\
\text { (em.) }\end{array}$ & $\begin{array}{c}\text { Wt. } \\
\text { (gm.) }\end{array}$ & $\begin{array}{l}\text { Lth. } \\
\text { (cm.) }\end{array}$ & $\begin{array}{c}\text { Wt. } \\
\text { (gm.) }\end{array}$ & & & & & & & $\begin{array}{l}\text { Lth. } \\
\text { (em. }\end{array}$ & $\begin{array}{l}\text { Wt. } \\
\text { (gm.) }\end{array}$ \\
\hline Jan. 6 & $17 \cdot 6$ & $52 \cdot 8$ & - & - & - & - & - & - & - & - & - & \\
\hline , 20 & $17 \cdot 6$ & $50 \cdot 5$ & nil & $-2 \cdot 3$ & $5 \cdot 7$ & 14 & $0 \cdot 41$ & 0.008 & $5 \cdot 7$ & 14 & nil & -2 \\
\hline Feb. 3 & $17 \cdot 6$ & $50 \cdot 2$ & nil & -0.3 & $6 \cdot 1$ & 14 & 0.44 & 0.009 & $11 \cdot 8$ & 28 & nil & -2 \\
\hline,,$\quad 17$ & $17 \cdot 6$ & $50 \cdot 9$ & nil & $0 \cdot 7$ & $8 \cdot 5$ & 14 & $0 \cdot 61$ & 0.012 & $21 \cdot 3$ & 42 & nil & -1 \\
\hline Mar. 3 & $17 \cdot 7$ & $51 \cdot 8$ & 0.1 & $0 \cdot 9$ & $12 \cdot 6$ & 14 & 0.90 & 0.018 & 33.9 & 56 & $0 \cdot 1$ & -1 \\
\hline,,$\quad 17$ & $17 \cdot 6$ & $51 \cdot 0$ & $-0 \cdot 1$ & -0.8 & $9 \cdot 8$ & 14 & $0 \cdot 70$ & 0.014 & $43 \cdot 7$ & 70 & nil & -1 \\
\hline,$\quad 31$ & $17 \cdot 7$ & $51 \cdot 8$ & $0 \cdot 1$ & 0.8 & $10 \cdot 5$ & 14 & $0 \cdot 75$ & 0.015 & $54 \cdot 2$ & 84 & $0 \cdot 1$ & $-1 \cdot$ \\
\hline April 14 & $17 \cdot 7$ & $52 \cdot 8$ & nil & $1 \cdot 0$ & $10 \cdot 5$ & 14 & $0 \cdot 75$ & 0.014 & $64 \cdot 7$ & 98 & $0 \cdot 1$ & \\
\hline ", 28 & $17 \cdot 7$ & $51 \cdot 6$ & nil & $-1 \cdot 2$ & $10 \cdot 1$ & 14 & 0.72 & 0.014 & $74 \cdot 8$ & 112 & $0 \cdot 1$ & -1 \\
\hline
\end{tabular}

TABLE 39: L4W (ô).

\begin{tabular}{|c|c|c|c|c|c|c|c|c|c|c|c|c|}
\hline Jan. 6 & $21 \cdot 1$ & $78 \cdot 8$ & - & - & - & - & - & - & - & - & - & - \\
\hline,$\quad 20$ & $21 \cdot 1$ & $76 \cdot 9$ & nil & $-1 \cdot 9$ & $10 \cdot 9$ & 14 & $0 \cdot 78$ & 0.010 & $10 \cdot 9$ & 14 & nil & $-1 \cdot 9$ \\
\hline Feb. 3 & $21 \cdot 1$ & $77 \cdot 6$ & nil & 0.7 & $10 \cdot 8$ & 14 & $0 \cdot 77$ & 0.010 & $21 \cdot 7$ & 28 & nil & $-1 \cdot 2$ \\
\hline,$\quad 17$ & $21 \cdot 1$ & $79 \cdot 4$ & nil & $1 \cdot 8$ & $13 \cdot 6$ & 14 & 0.97 & 0.011 & $35 \cdot 3$ & 42 & nil & 0.6 \\
\hline Mar. 3 & $21 \cdot 2$ & $79 \cdot 3$ & nil & -0.1 & $15 \cdot 6$ & 14 & $1 \cdot 11$ & 0.014 & $50 \cdot 9$ & 56 & nil & $0 \cdot 5$ \\
\hline,$\quad 17$ & $21 \cdot 1$ & $81 \cdot 3$ & nil & $2 \cdot 0$ & $15 \cdot 4$ & 14 & $1 \cdot 10$ & $0 \cdot 014$ & $64 \cdot 3$ & 70 & nil & $2 \cdot 5$ \\
\hline,$\quad 31$ & $21 \cdot 1$ & $79 \cdot 6$ & nil & $-1 \cdot 7$ & $13 \cdot 5$ & 14 & $0 \cdot 96$ & 0.012 & $79 \cdot 8$ & 84 & nil & $0 \cdot 8$ \\
\hline April 14 & $20 \cdot 9$ & $81 \cdot 8$ & $-0 \cdot 2$ & $2 \cdot 2$ & $15 \cdot 4$ & 14 & $1 \cdot 10$ & 0.014 & $95 \cdot 2$ & 98 & $-0 \cdot 2$ & $3 \cdot 0$ \\
\hline 28 & $20 \cdot 9$ & $79 \cdot 0$ & nil & $-2 \cdot 8$ & $14 \cdot 3$ & 14 & 1.02 & 0.013 & $109 \cdot 5$ & 112 & $-0 \cdot 2$ & $0 \cdot 2$ \\
\hline
\end{tabular}

TABLE 40: L5w (ㅇ).

\begin{tabular}{|c|c|c|c|c|c|c|c|c|c|c|c|c|}
\hline Jan. 6 & 18.9 & $69 \cdot 8$ & - & - & - & - & - & - & - & - & - & - \\
\hline$\Rightarrow \quad 20$ & $18 \cdot 9$ & $69 \cdot 6$ & nil & $-0 \cdot 2$ & $9 \cdot 0$ & 14 & 0.64 & $0 \cdot 009$ & $9 \cdot 0$ & 14 & nil & $-0 \cdot 2$ \\
\hline Feb. 3 & $19 \cdot 0$ & $69 \cdot 8$ & 0.1 & $0 \cdot 2$ & $6 \cdot 0$ & 14 & $0 \cdot 43$ & 0.006 & $15 \cdot 0$ & 28 & $0 \cdot 1$ & nil \\
\hline,,$\quad 17$ & $19 \cdot 0$ & $73 \cdot 1$ & nil & $3 \cdot 3$ & $16 \cdot 1$ & 14 & $1 \cdot 15$ & 0.016 & $31 \cdot 1$ & 42 & $0 \cdot 1$ & $3 \cdot 3$ \\
\hline Mar. & $19 \cdot 2$ & $75 \cdot 9$ & $0 \cdot 2$ & $2 \cdot 8$ & $18 \cdot 0$ & 14 & $1 \cdot 29$ & $0 \cdot 017$ & $49 \cdot 1$ & 56 & $0 \cdot 3$ & $6 \cdot 1$ \\
\hline ,, 17 & $19 \cdot 5$ & $76 \cdot 3$ & $0 \cdot 3$ & 0.4 & $14 \cdot 0$ & 14 & $1 \cdot 00$ & 0.013 & $63 \cdot 1$ & 70 & $0 \cdot 6$ & $6 \cdot 5$ \\
\hline 31 & $19 \cdot 7$ & $77 \cdot 9$ & $0 \cdot 2$ & $1 \cdot 6$ & $13 \cdot 1$ & 14 & $0 \cdot 93$ & 0.012 & $76 \cdot 1$ & 84 & 0.8 & $8 \cdot 1$ \\
\hline April 14 & $19 \cdot 9$ & $79 \cdot 1$ & $0 \cdot 2$ & $1 \cdot 2$ & $10 \cdot 4$ & 14 & 0.75 & 0.010 & $86 \cdot 6$ & 98 & 1.0 & $9 \cdot 3$ \\
\hline 28 & $20 \cdot 0$ & $78 \cdot 2$ & $0 \cdot 1$ & -0.9 & $9 \cdot 9$ & 14 & 0.71 & $0 \cdot 009$ & $96 \cdot 5$ & 112 & $1 \cdot 1$ & $8 \cdot 4$ \\
\hline
\end{tabular}

TABLe $41:$ L7W (ㅇ).

\begin{tabular}{|c|c|c|c|c|c|c|c|c|c|c|c|c|}
\hline Jan. 6 & $22 \cdot 7$ & $103 \cdot 4$ & 一 & - & - & - & - & - & - & - & - & \\
\hline,$\quad 20$ & $22 \cdot 7$ & $101 \cdot 2$ & nil & $-2 \cdot 2$ & $13 \cdot 5$ & 14 & 0.96 & 0.009 & $13 \cdot 5$ & 14 & nil & $-2 \cdot 2$ \\
\hline Feb. 3 & $22 \cdot 7$ & $101 \cdot 1$ & nil & -0.1 & $12 \cdot 0$ & 14 & $0 \cdot 86$ & 0.009 & $25 \cdot 5$ & 28 & nil & $-2 \cdot 3$ \\
\hline , 17 & $22 \cdot 7$ & $102 \cdot 4$ & nil & $1 \cdot 3$ & $8 \cdot 9$ & 14 & $0 \cdot 64$ & 0.006 & $34 \cdot 4$ & 42 & nil & $-1 \cdot 0$ \\
\hline Mar. 3 & $22 \cdot 7$ & $101 \cdot 5$ & nil & -0.9 & $11 \cdot 4$ & 14 & 0.81 & 0.008 & $45 \cdot 8$ & 56 & nil & $-1 \cdot 9$ \\
\hline 17 & $22 \cdot 7$ & $100 \cdot 2$ & nil & $-1 \cdot 3$ & $10 \cdot 3$ & 14 & $0 \cdot 74$ & $0 \cdot 007$ & $56 \cdot 1$ & 70 & nil & $-3 \cdot 2$ \\
\hline,$\quad 31$ & $22 \cdot 7$ & $99 \cdot 9$ & nil & $-0 \cdot 3$ & $11 \cdot 4$ & 14 & $0 \cdot 81$ & 0.008 & $67 \cdot 5$ & 84 & nil & $-3 \cdot 5$ \\
\hline April 14 & $22 \cdot 7$ & $100 \cdot 4$ & nil & 0.5 & $11 \cdot 9$ & 14 & $0 \cdot 85$ & $0 \cdot 008$ & $79 \cdot 4$ & 98 & nil & $-3 \cdot 0$ \\
\hline 28 & $22 \cdot 7$ & $97 \cdot 6$ & nil & $-2 \cdot 8$ & $11 \cdot 8$ & 14 & $0 \cdot 84$ & 0.009 & $91 \cdot 2$ & 112 & nil & $-5 \cdot 8$ \\
\hline
\end{tabular}


TABLE 42.

Summarised Data Concerning Maintenance Requirements of Male and Female Plaice during 1929 AND 1930 (JAN.-ApriL), (PARtLy from my Previous Paper).

\begin{tabular}{|c|c|c|c|c|c|c|c|c|c|c|c|c|c|}
\hline \multirow{2}{*}{$\begin{array}{l}\text { Fish } \\
\text { No. }\end{array}$} & \multirow[b]{2}{*}{ Sex. } & \multicolumn{2}{|c|}{$\begin{array}{l}\text { Initial } \\
\text { size. }\end{array}$} & \multicolumn{2}{|c|}{$\begin{array}{c}\text { Final } \\
\text { size. }\end{array}$} & \multicolumn{2}{|c|}{ Growth. } & \multicolumn{2}{|c|}{ Period. } & \multirow{2}{*}{$\begin{array}{c}\text { No. of } \\
\text { days } \\
\text { in } \\
\text { period. }\end{array}$} & \multirow{2}{*}{$\begin{array}{c}\text { Average } \\
\text { quantity } \\
\text { of food } \\
\text { per day } \\
\text { for period. }\end{array}$} & \multirow{2}{*}{$\begin{array}{c}\text { Ratio } \\
\text { Food per } \\
\text { day/ } \\
/ \mathrm{mid} \\
\text { body. } \\
\text { weight } \\
\text { for period. }\end{array}$} & \multirow[t]{2}{*}{ Year. } \\
\hline & & $\begin{array}{l}\text { Lth. } \\
\text { (cm.) }\end{array}$ & $\begin{array}{l}\text { Wt. } \\
\text { (gm.) }\end{array}$ & $\begin{array}{l}\text { Lth. } \\
\text { (cm.) }\end{array}$ & $\begin{array}{c}\text { Wt. } \\
\text { (gm.) }\end{array}$ & $\begin{array}{l}\text { Lth. } \\
\text { (cm.) }\end{array}$ & $\begin{array}{l}\text { Wt. } \\
\text { (gm.) }\end{array}$ & From & To & & & & \\
\hline \multirow[t]{2}{*}{ L1 } & ô & $17 \cdot 0$ & $50 \cdot 3$ & $17 \cdot 6$ & $54 \cdot 1$ & $0 \cdot 6$ & $3 \cdot 8$ & $22: 8$ & $25: 11$ & 95 & $0 \cdot 90$ & $0 \cdot 017$ & 1929 \\
\hline & & $17 \cdot 6$ & $52 \cdot 8$ & $17 \cdot 7$ & $51 \cdot 6$ & $0 \cdot 1$ & $-1 \cdot 2$ & $6: 1$ & $28: 4$ & 112 & 0.58 & $0 \cdot 011$ & 1930 \\
\hline \multirow[t]{2}{*}{ L4b } & $\widehat{\sigma}$ & $20 \cdot 8$ & $75 \cdot 1$ & $21 \cdot 0$ & $76 \cdot 9$ & $0 \cdot 2$ & $1 \cdot 8$ & $30: 9$ & $25: 11$ & 56 & $1 \cdot 11$ & $0 \cdot 015$ & 1929 \\
\hline & & $21 \cdot 1$ & $78 \cdot 8$ & $20 \cdot 9$ & $79 \cdot 0$ & $-0 \cdot 2$ & $0 \cdot 2$ & $6: 1$ & $28: 4$ & 112 & 0.98 & $0 \cdot 012$ & 1930 \\
\hline \multirow[t]{2}{*}{ L5 } & 우 & $18 \cdot 5$ & $62 \cdot 8$ & $18 \cdot 6$ & $66 \cdot 9$ & $0 \cdot 1$ & $4 \cdot 1$ & $8: 8$ & $25: 11$ & 109 & $0 \cdot 88$ & $0 \cdot 014$ & 1929 \\
\hline & & $18 \cdot 9$ & $69 \cdot 8$ & $20 \cdot 0$ & $78 \cdot 2$ & $1 \cdot 1$ & $8 \cdot 4$ & $6: 1$ & $28: 4$ & 112 & $0 \cdot 86$ & $0 \cdot 012$ & 1930 \\
\hline \multirow[t]{2}{*}{ L7 } & 우 & $22 \cdot 3$ & $104 \cdot 8$ & $22 \cdot 7$ & $100 \cdot 6$ & $0 \cdot 4$ & $-4 \cdot 3$ & $4: 9$ & $25: 11$ & 82 & $1 \cdot 32$ & $0 \cdot 013$ & 1929 \\
\hline & & $22 \cdot 7$ & $103 \cdot 4$ & $22 \cdot 7$ & $97 \cdot 6$ & nil & $-5 \cdot 8$ & $6: 1$ & $28: 4$ & 112 & $0 \cdot 81$ & $0 \cdot 008$ & 1930 \\
\hline
\end{tabular}


TABLE 43.

Summarised Data Showing Maintenance Requirements during January-April of Male and Female, “Minimum-fed" and “Maximum-fed” Plaice.

\begin{tabular}{|c|c|c|c|c|c|c|c|c|c|c|c|c|c|}
\hline \multirow{3}{*}{$\begin{array}{l}\text { Fish } \\
\text { No. } \\
\text { L1w }\end{array}$} & \multirow{3}{*}{$\begin{array}{r}\text { Sex. } \\
\hat{\sigma}\end{array}$} & \multicolumn{2}{|c|}{$\begin{array}{c}\text { Initial } \\
\text { size. }\end{array}$} & \multicolumn{2}{|c|}{$\begin{array}{c}\text { Final } \\
\text { size. }\end{array}$} & \multicolumn{2}{|c|}{ Growth. } & \multicolumn{2}{|c|}{ Period } & \multirow{2}{*}{$\begin{array}{l}\text { No. of } \\
\text { days } \\
\text { in } \\
\text { period. }\end{array}$} & \multirow{2}{*}{\multicolumn{2}{|c|}{$\begin{array}{cc} & \text { Ratio } \\
\text { Average } & \text { Food per } \\
\text { quantity } & \text { day/ } / \\
\text { of food } & / \mathrm{mid} \\
\text { per day } & \text { body- } \\
\text { for period. } & \text { weight } \\
& \text { for period. }\end{array}$}} & \\
\hline & & $\begin{array}{l}\text { Lth. } \\
\text { (c.m) }\end{array}$ & $\begin{array}{l}\text { Wt. } \\
\text { (gm.) }\end{array}$ & $\begin{array}{l}\text { Lth. } \\
\text { (cm.) }\end{array}$ & $\begin{array}{l}\text { Wt. } \\
\text { (gm.) }\end{array}$ & $\begin{array}{l}\text { Lth. } \\
\text { (cm.) }\end{array}$ & $\begin{array}{c}\text { Wt. } \\
\text { (gm.) }\end{array}$ & From & To & & & & \\
\hline & & $17 \cdot 6$ & $52 \cdot 8$ & $17 \cdot 7$ & $51 \cdot 8$ & $0 \cdot 1$ & $-1 \cdot 0$ & $6: 1$ & $3: 3$ & 56 & $0 \cdot 61$ & $0 \cdot 012$ & \\
\hline L4w & $\widehat{0}$ & $21 \cdot 1$ & $78 \cdot 8$ & $21 \cdot 1$ & $79 \cdot 3$ & nil & $0 \cdot 5$ & $6: 1$ & $3: 3$ & 56 & $0 \cdot 91$ & $0 \cdot 012$ & $\begin{array}{l}\text { MINI- } \\
\text { MUM }\end{array}$ \\
\hline L5w & 우 & $18 \cdot 9$ & $69 \cdot 8$ & $19 \cdot 2$ & $75 \cdot 9$ & $0 \cdot 3$ & $6 \cdot 1$ & $6: 1$ & $3: 3$ & 56 & $0 \cdot 88$ & $0 \cdot 012$ & FISH. \\
\hline $\mathrm{L} 7 \mathrm{w}$ & 우 & $22 \cdot 7$ & $103 \cdot 4$ & $22 \cdot 7$ & $101 \cdot 5$ & nil & $-1 \cdot 9$ & $6: 1$ & $3: 3$ & 56 & $0 \cdot 67$ & 0.007 & \\
\hline L10w & $\widehat{0}$ & $23 \cdot 1$ & $117 \cdot 2$ & $23 \cdot 1$ & $112 \cdot 5$ & nil & $-4 \cdot 7$ & $6: 1$ & $3: 3$ & 56 & $0 \cdot 02$ & 0.000 & \\
\hline L12w & శ & $22 \cdot 0$ & $105 \cdot 3$ & $22 \cdot 0$ & $101 \cdot 7$ & nil & $-3 \cdot 6$ & $6: 1$ & $3: 3$ & 56 & $0 \cdot 01$ & $0 \cdot 000$ & $\begin{array}{c}\text { Maxi- } \\
\text { MUM }\end{array}$ \\
\hline L13w & 우 & $19 \cdot 2$ & $68 \cdot 3$ & $19 \cdot 2$ & $66 \cdot 3$ & nil & $-2 \cdot 0$ & $6: 1$ & $3: 3$ & 56 & $0 \cdot 02$ & $0 \cdot 000$ & Fish. \\
\hline L15w & 우 & $23 \cdot 1$ & $132 \cdot 7$ & $23 \cdot 2$ & $130 \cdot 3$ & $0 \cdot 1$ & $-2 \cdot 4$ & $6: 1$ & $3: 3$ & 56 & $0 \cdot 02$ & 0.000 & \\
\hline
\end{tabular}


TABLES $44-47$.

Maximum Requirements of Male and Female Plaice (JAN.-APRIL).

TABLE $44:$ L10w (ठิ).

\begin{tabular}{|c|c|c|c|c|c|c|c|c|c|c|c|c|c|}
\hline \multirow{2}{*}{$\begin{array}{l}\text { Date. } \\
(1930)\end{array}$} & & & \multirow[t]{2}{*}{ Wt./Lth. ${ }^{3}$} & $\begin{array}{c}\text { Gro } \\
\text { per } \\
\text { por }\end{array}$ & $\begin{array}{l}\text { wth } \\
\text { er } \\
\text { iod. }\end{array}$ & \multirow{2}{*}{$\begin{array}{c}\text { Total } \\
\text { food } \\
\text { per } \\
\text { period. } \\
\text { (gm.) }\end{array}$} & \multirow[t]{2}{*}{$\begin{array}{c}\text { Gm. of } \\
\text { food } \\
\text { per } \\
1.0 \mathrm{gm} . \\
\text { increase } \\
\text { in } \\
\text { weight } \\
\text { of fish. }\end{array}$} & \multirow[t]{2}{*}{$\begin{array}{c}\text { No. of } \\
\text { days } \\
\text { in } \\
\text { period. }\end{array}$} & \multirow{2}{*}{$\begin{array}{c}\text { Average } \\
\text { food } \\
\text { per day } \\
\text { during } \\
\text { each } \\
\text { period. } \\
\text { (gm.) }\end{array}$} & \multirow{2}{*}{$\begin{array}{l}\text { Percent- } \\
\text { age } \\
\text { growth } \\
\text { in wt. }\end{array}$} & \multirow{2}{*}{$\begin{array}{l}\text { Total } \\
\text { food } \\
\text { to date } \\
\text { (gm.) }\end{array}$} & \multicolumn{2}{|c|}{$\begin{array}{l}\text { Cumulative } \\
\text { growth. }\end{array}$} \\
\hline & $\begin{array}{l}\text { Lth. } \\
(\mathrm{cm} .)\end{array}$ & $\begin{array}{l}\text { Wt. } \\
\text { (gm.) }\end{array}$ & & $\begin{array}{l}\text { Lth. } \\
(\mathrm{cm} .)\end{array}$ & $\begin{array}{c}\text { Wt. } \\
\text { (gm.) }\end{array}$ & & & & & & & $\begin{array}{l}\text { Lth. } \\
\text { (cm.) }\end{array}$ & $\underset{(\mathrm{gm} .)}{\mathrm{Wt} .}$ \\
\hline Jan. 6 & $23 \cdot 1$ & $117 \cdot 2$ & 0.010 & - & - & - & - & - & - & - & - & - & 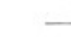 \\
\hline,$\quad 20$ & $23 \cdot 1$ & $112 \cdot 5$ & $0 \cdot 009$ & nil & $-4 \cdot 7$ & $7 \cdot 0$ & - & 14 & $0 \cdot 50$ & - & 7 & nil & $-4 \cdot 7$ \\
\hline Feb. 3 & $23 \cdot 1$ & $111 \cdot 0$ & 0.009 & nil & $-1 \cdot 5$ & $1 \cdot 2$ & - & 14 & $0 \cdot 09$ & - & 8 & nil & $-6 \cdot 2$ \\
\hline , 17 & $23 \cdot 1$ & $110 \cdot 2$ & $0 \cdot 009$ & nil & $-0 \cdot 8$ & $1 \cdot 5$ & - & 14 & 0.11 & - & 10 & nil & $-7 \cdot 0$ \\
\hline Mar. 3 & $23 \cdot 1$ & $112 \cdot 5$ & $0 \cdot 009$ & nil & $2 \cdot 3$ & $12 \cdot 3$ & $5 \cdot 3$ & 14 & $0 \cdot 88$ & $2 \cdot 1$ & 22 & nil & $-4 \cdot 7$ \\
\hline,,$\quad 17$ & $23 \cdot 3$ & $118 \cdot 0$ & $0 \cdot 009$ & $0 \cdot 2$ & $5 \cdot 5$ & $37 \cdot 4$ & $6 \cdot 8$ & 14 & $2 \cdot 67$ & $4 \cdot 9$ & 59 & $0 \cdot 2$ & $0 \cdot 8$ \\
\hline , $\quad 31$ & $23 \cdot 5$ & $123 \cdot 8$ & $0 \cdot 009$ & $0 \cdot 2$ & $5 \cdot 8$ & $46 \cdot 4$ & $8 \cdot 0$ & 14 & $3 \cdot 31$ & $4 \cdot 9$ & 106 & $0 \cdot 4$ & $6 \cdot 6$ \\
\hline April 14 & $23 \cdot 7$ & $129 \cdot 3$ & 0.009 & $0 \cdot 2$ & $5 \cdot 5$ & $55 \cdot 6$ & $10 \cdot 1$ & 14 & $3 \cdot 97$ & $4 \cdot 4$ & 162 & $0 \cdot 6$ & $12 \cdot 1$ \\
\hline,$\quad 28$ & $23 \cdot 7$ & $128 \cdot 2$ & $0 \cdot 009$ & nil & $-1 \cdot 1$ & $62 \cdot 5$ & - & 14 & $4 \cdot 46$ & - & 224 & $0 \cdot 6$ & $11 \cdot 0$ \\
\hline
\end{tabular}

TABLe 45: L12W (ठ)).

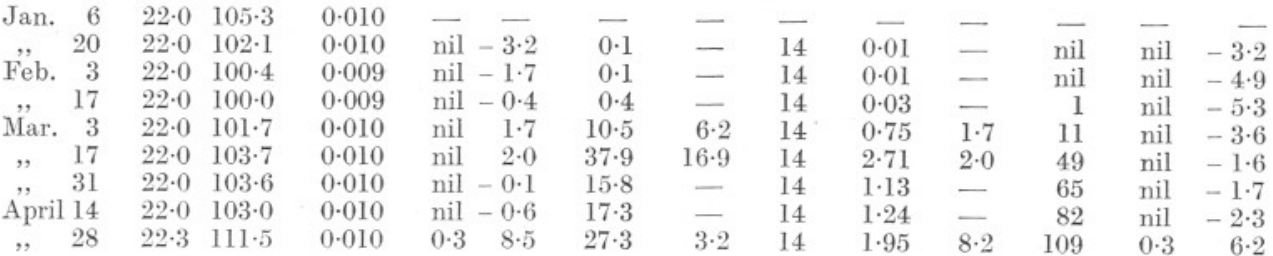

TABLE 46: L13w (穴).

\begin{tabular}{|c|c|c|c|c|c|c|c|c|c|c|c|c|c|}
\hline Jan. & $19 \cdot 2$ & $68 \cdot 3$ & 0.010 & - & - & - & - & - & - & - & - & - & - \\
\hline,,$\quad 2$ & $19 \cdot 2$ & $66 \cdot 3$ & 0.009 & nil & $-2 \cdot 0$ & $0 \cdot 9$ & - & 14 & 0.06 & - & 1 & nil & $-2 \cdot 0$ \\
\hline Feb. : & $19 \cdot 2$ & $65 \cdot 0$ & 0.009 & nil & $-1 \cdot 3$ & $1 \cdot 0$ & - & 14 & 0.07 & - & 2 & nil & $-3 \cdot 3$ \\
\hline,$\quad 17$ & $19 \cdot 2$ & $64 \cdot 0$ & $0 \cdot 009$ & nil & $-1 \cdot 0$ & $1 \cdot 8$ & - & 14 & $0 \cdot 13$ & - & 4 & nil & $-4 \cdot 3$ \\
\hline Mar. : & $19 \cdot 2$ & $66 \cdot 3$ & $0 \cdot 009$ & nil & $2 \cdot 3$ & $12 \cdot 6$ * & $5 \cdot 5$ & 14 & 0.90 & $3 \cdot 6$ & 16 & nil & $-2 \cdot 0$ \\
\hline,,$\quad 17$ & $19 \cdot 3$ & $71 \cdot 5$ & $0 \cdot 010$ & $0 \cdot 1$ & $5 \cdot 2$ & $35 \cdot 1$ & 6.7 & 14 & $2 \cdot 51$ & $7 \cdot 8$ & 51 & $0 \cdot 1$ & $3 \cdot 2$ \\
\hline , $\quad 3$ & $19 \cdot 5$ & $74 \cdot 0$ & $0 \cdot 010$ & $0 \cdot 2$ & $2 \cdot 5$ & $40 \cdot 1$ & $16 \cdot 1$ & 14 & $2 \cdot 87$ & $3 \cdot 5$ & 92 & $0 \cdot 3$ & $5 \cdot 7$ \\
\hline April 14 & $19 \cdot 5$ & $75 \cdot 5$ & $0 \cdot 010$ & nil & $1 \cdot 5$ & $42 \cdot 9$ & $28 \cdot 6$ & 14 & $3 \cdot 06$ & $2 \cdot 0$ & 135 & $0 \cdot 3$ & $7 \cdot 2$ \\
\hline,$\quad 28$ & $19 \cdot 8$ & $80 \cdot 8$ & 0.010 & $0 \cdot 3$ & $5 \cdot 3$ & $47 \cdot 5$ & $9 \cdot 0$ & 14 & $3 \cdot 39$ & $7 \cdot 0$ & 182 & $0 \cdot 6$ & $12 \cdot 5$ \\
\hline
\end{tabular}

TABLE 47 : L15w (ㅇ).

\begin{tabular}{|c|c|c|c|c|c|c|c|c|c|c|c|c|}
\hline Jan. 6 & $23 \cdot 1$ & $132 \cdot 7$ & 0.011 & $-\quad-$ & - & - & - & - & - & - & - & 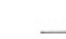 \\
\hline,$\quad 20$ & $23 \cdot 1$ & $129 \cdot 5$ & 0.011 & nil $-3 \cdot 2$ & $3 \cdot 0$ & - & 14 & $0 \cdot 21$ & - & 3 & nil & $-3 \cdot 2$ \\
\hline Feb. 3 & $23 \cdot 2$ & $128 \cdot 0$ & 0.010 & $0 \cdot 1-1 \cdot 5$ & 0.9 & - & 14 & 0.06 & - & 4 & $0 \cdot 1$ & $-4 \cdot 7$ \\
\hline,,$\quad 17$ & $23 \cdot 2$ & $126 \cdot 0$ & 0.010 & nil $-2 \cdot 0$ & $1 \cdot 2$ & - & 14 & 0.09 & - & 5 & $0 \cdot 1$ & $-6 \cdot 7$ \\
\hline Mar. 3 & $23 \cdot 2$ & $130 \cdot 3$ & 0.010 & nil $4 \cdot 3$ & $12.5 \dagger$ & $2 \cdot 9$ & 14 & $0 \cdot 89$ & $3 \cdot 4$ & 18 & $0 \cdot 1$ & $-2 \cdot 4$ \\
\hline,,$\quad 17$ & $23 \cdot 5$ & $135 \cdot 1$ & 0.010 & $4 \cdot 8$ & $39 \cdot 4$ & $8 \cdot 2$ & 14 & $2 \cdot 81$ & $3 \cdot 7$ & 57 & 0.4 & $2 \cdot 4$ \\
\hline,$\quad 31$ & $23 \cdot 5$ & $138 \cdot 8$ & 0.011 & $3 \cdot 7$ & $45 \cdot 1$ & $12 \cdot 2$ & 14 & $3 \cdot 22$ & $2 \cdot 7$ & 102 & 0.4 & $6 \cdot 1$ \\
\hline April 14 & $23 \cdot 5$ & $152 \cdot 4$ & 0.012 & nil $13 \cdot 6$ & $43 \cdot 6$ & $3 \cdot 2$ & 14 & $.3 \cdot 11$ & $9 \cdot 8$ & 146 & $0 \cdot 4$ & $19 \cdot 7$ \\
\hline , 28 & $23 \cdot 7$ & $128 \cdot 8$ & $0 \cdot 010$ & $0 \cdot 2-23 \cdot 6_{+}^{+}$ & $46 \cdot 6$ & - & 14 & $3 \cdot 33$ & - & 192 & 0.6 & $-3 \cdot 9$ \\
\hline
\end{tabular}

- May be $10 \cdot 3$. 1 daily ration of doubtful value. t May be 10*4. See footnotes to Table 46 . 
TABLES 48-51.

Maintenance Requirements of Male Platce.

Table 48: L1.

\begin{tabular}{|c|c|c|c|c|c|c|c|c|c|c|c|c|}
\hline \multirow[t]{2}{*}{$\begin{array}{c}\text { Date } \\
(1930)\end{array}$} & \multicolumn{2}{|c|}{$\begin{array}{c}\text { Size } \\
\text { of fish. }\end{array}$} & \multicolumn{2}{|c|}{$\begin{array}{l}\text { Growth } \\
\text { per } \\
\text { Deriod. }\end{array}$} & \multirow{2}{*}{$\begin{array}{c}\text { Weight } \\
\text { of food } \\
\text { per } \\
\text { period. } \\
\text { (gm.) }\end{array}$} & \multirow[t]{2}{*}{$\begin{array}{c}\text { No. of } \\
\text { days } \\
\text { in } \\
\text { period. }\end{array}$} & \multirow{2}{*}{$\begin{array}{c}\text { Average } \\
\text { weight } \\
\text { of food } \\
\text { per day. } \\
\text { (gm.) }\end{array}$} & \multirow{2}{*}{$\begin{array}{c}\text { Ratio of } \\
\text { food per } \\
\text { day/ } \\
\text { /average } \\
\text { body-wt. } \\
\text { for } \\
\text { period. }\end{array}$} & \multirow{2}{*}{$\begin{array}{c}\text { Total } \\
\text { wt. of } \\
\text { food } \\
\text { to date. } \\
\text { (gm.) }\end{array}$} & \multirow{2}{*}{$\begin{array}{l}\text { No. of } \\
\text { days } \\
\text { since } \\
\text { com- } \\
\text { mence- } \\
\text { ment of } \\
\text { expt. }\end{array}$} & \multicolumn{2}{|c|}{$\begin{array}{l}\text { Cumulative } \\
\text { growth. }\end{array}$} \\
\hline & $\begin{array}{l}\text { Ith. } \\
(\mathrm{cm} .)\end{array}$ & $\begin{array}{l}\text { Wt. } \\
\text { (gm.) }\end{array}$ & $\begin{array}{l}\text { Lth. } \\
\text { (em.) }\end{array}$ & $\begin{array}{l}\text { Wt. } \\
\text { (gm.) }\end{array}$ & & & & & & & $\begin{array}{l}\text { Lth. } \\
\text { (cm.) }\end{array}$ & $\begin{array}{l}\text { Wt } \\
\text { (gm.) }\end{array}$ \\
\hline May 12 & $17 \cdot 9$ & $62 \cdot 2$ & - & - & - & - & - & - & - & - & - & 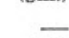 \\
\hline$\Rightarrow 26$ & $18 \cdot 0$ & $59 \cdot 5$ & $0 \cdot 1$ & $-2 \cdot 7$ & $6 \cdot 5$ & 14 & $0 \cdot 47$ & 0.008 & $6 \cdot 5$ & 14 & $0 \cdot 1$ & $-2 \cdot 7$ \\
\hline June 9 & $18 \cdot 0$ & $59 \cdot 9$ & nil & 0.4 & $9 \cdot 9$ & 14 & $0 \cdot 71$ & 0.012 & $16 \cdot 4$ & 28 & $0 \cdot 1$ & $-2 \cdot 3$ \\
\hline " 23 & $18 \cdot 0$ & $59 \cdot 3$ & nil & -0.6 & $9 \cdot 9$ & 14 & $0 \cdot 71$ & 0.012 & $26 \cdot 3$ & 42 & $0 \cdot 1$ & $-2 \cdot 9$ \\
\hline July 7 & $18 \cdot 0$ & $59 \cdot 0$ & nil & $-0 \cdot 3$ & $10 \cdot 6$ & 14 & $0 \cdot 76$ & 0.013 & $36 \cdot 9$ & 56 & $0 \cdot 1$ & $-3 \cdot 2$ \\
\hline$\Rightarrow \quad 21$ & $18 \cdot 0$ & $57 \cdot 3$ & nil & $-1 \cdot 7$ & $10 \cdot 6$ & 14 & $0 \cdot 76$ & $0 \cdot 013$ & $47 \cdot 5$ & 70 & $0 \cdot 1$ & $-4 \cdot 9$ \\
\hline Aug. 4 & $18 \cdot 0$ & $57 \cdot 7$ & nil & $0 \cdot 4$ & $12 \cdot 4$ & 14 & $0 \cdot 89$ & 0.015 & $59 \cdot 9$ & 84 & $0 \cdot 1$ & $-4 \cdot 5$ \\
\hline ", 18 & $18 \cdot 0$ & $58 \cdot 0$ & nil & $0 \cdot 3$ & $12 \cdot 2$ & 14 & $0 \cdot 87$ & 0.015 & $72 \cdot 1$ & 98 & $0 \cdot 1$ & $-4 \cdot 2$ \\
\hline Sept. 1 & $18 \cdot 0$ & $56 \cdot 5$ & nil & $-1 \cdot 5$ & $11 \cdot 6$ & 14 & $0 \cdot 83$ & 0.015 & $83 \cdot 7$ & 112 & $0 \cdot 1$ & $-5 \cdot 7$ \\
\hline ,, 15 & $18 \cdot 0$ & $56 \cdot 8$ & nil & $0 \cdot 3$ & $19 \cdot 7$ & 14 & $1 \cdot 41$ & 0.025 & $103 \cdot 4$ & 126 & $0 \cdot 1$ & $-5 \cdot 4$ \\
\hline$\Rightarrow \quad 29$ & $18 \cdot 1$ & $57 \cdot 1$ & $0 \cdot 1$ & $0 \cdot 3$ & $12 \cdot 7$ & 14 & 0.91 & 0.016 & $116 \cdot 1$ & 140 & $0 \cdot 2$ & $-5 \cdot 1$ \\
\hline Oct. 13 & $18 \cdot 1$ & $56 \cdot 1$ & nil & $-1 \cdot 0$ & $12 \cdot 6$ & 14 & 0.90 & 0.016 & $128 \cdot 7$ & 154 & $0 \cdot 2$ & $-6 \cdot 1$ \\
\hline $\begin{array}{ll}27 & 27 \\
\end{array}$ & $18 \cdot 1$ & $55 \cdot 9$ & nil & -0.2 & $13 \cdot 7$ & 14 & $0 \cdot 98$ & 0.017 & $142 \cdot 4$ & 168 & $0 \cdot 2$ & $-6 \cdot 3$ \\
\hline Nov. 10 & $18 \cdot 1$ & $57 \cdot 5$ & nil & $1 \cdot 6$ & $13 \cdot 9$ & 14 & $0 \cdot 98$ & $0 \cdot 017$ & $156 \cdot 3$ & 182 & $0 \cdot 2$ & $-4 \cdot 7$ \\
\hline 24 & $18 \cdot 1$ & $59 \cdot 2$ & nil & 1.7 & $12 \cdot 3$ & 14 & $0 \cdot 88$ & 0.015 & $168 \cdot 6$ & 196 & $0 \cdot 2$ & $-3 \cdot 0$ \\
\hline
\end{tabular}

TABLE 49: L2.

\begin{tabular}{|c|c|c|c|c|c|c|c|c|c|c|c|c|}
\hline May 2 & $20 \cdot 0$ & $65 \cdot 0$ & - & - & - & - & - & - & - & - & & \\
\hline June & $20 \cdot 0$ & $64 \cdot 8$ & nil & $-0 \cdot 2$ & $11 \cdot 9$ & 14 & $0 \cdot 85$ & 0.013 & $20 \cdot 2$ & 14 & nil & -0.2 \\
\hline,,$\quad 2$ & 20.0 & $64 \cdot 3$ & nil & -0.5 & 11.9 & 14 & 0.85 & 0.013 & $32 \cdot 1$ & 28 & nil & -0.7 \\
\hline July & $20 \cdot 0$ & $62 \cdot 2$ & nil & $-2 \cdot 1$ & $12 \cdot 6$ & 14 & 0.90 & 0.014 & $44 \cdot 7$ & 42 & nil & $-2 \cdot 8$ \\
\hline,$\quad 2$ & $20 \cdot 0$ & $60 \cdot 1$ & nil & $-2 \cdot 1$ & $14 \cdot 2$ & 14 & $1 \cdot 01$ & 0.017 & $58 \cdot 9$ & 56 & nil & $-4 \cdot 9$ \\
\hline Aug. & $20 \cdot 0$ & $60 \cdot 2$ & nil & 0.1 & $17 \cdot 1$ & 14 & $1 \cdot 22$ & 0.020 & $76 \cdot 0$ & 70 & nil & $-4 \cdot 8$ \\
\hline " 18 & $20 \cdot 0$ & $61 \cdot 2$ & nil & $1 \cdot 0$ & $16 \cdot 9$ & 14 & $1 \cdot 21$ & 0.020 & $92 \cdot 9$ & 84 & nil & $-3 \cdot 8$ \\
\hline Sept. & $20 \cdot 0$ & $60 \cdot 0$ & nil & $-1 \cdot 2$ & $16 \cdot 0$ & 14 & $1 \cdot 14$ & 0.019 & 108.9 & 98 & nil & $-5 \cdot 0$ \\
\hline$\Rightarrow \quad 1$ & $20 \cdot 2$ & $62 \cdot 6$ & $0 \cdot 2$ & $2 \cdot 6$ & $25 \cdot 8$ & 14 & $1 \cdot 84$ & 0.028 & $134 \cdot 7$ & 112 & $0 \cdot 2$ & $-2 \cdot 4$ \\
\hline , 2 ? & $20 \cdot 2$ & $63 \cdot 8$ & nil & $1 \cdot 2$ & $14 \cdot 2$ & 14 & $1 \cdot 02$ & $0 \cdot 016$ & $148 \cdot 9$ & 126 & $0 \cdot 2$ & $-1 \cdot 2$ \\
\hline Uct. 1: & $20 \cdot 2$ & $65 \cdot 1$ & nil & $1 \cdot 3$ & $12 \cdot 9$ & 14 & 0.92 & 0.014 & $161 \cdot 8$ & 140 & $0 \cdot 2$ & $0 \cdot 1$ \\
\hline Nov. 18 & $\begin{array}{l}20 \cdot 2 \\
20 \cdot 2\end{array}$ & $\begin{array}{l}69 \cdot 3 \\
70.3\end{array}$ & nil & $4 \cdot 4$ & $11 \cdot 6$ & 14 & $0 \cdot 83$ & 0.012 & $173 \cdot 4$ & 154 & $0 \cdot 2$ & $4 \cdot 5$ \\
\hline , 24 & $20 \cdot 2$ & $70 \cdot 1$ & nil & $\begin{array}{r}0.8 \\
-0.2\end{array}$ & $7 \cdot 3$ & 14 & $\begin{array}{l}0.52 \\
0.47\end{array}$ & 0.008 & $180 \cdot 7$ & 168 & $0 \cdot 2$ & $5 \cdot 3$ \\
\hline & & & & & & & & 0.007 & $187 \cdot 3$ & 182 & $0 \cdot 2$ & $5 \cdot 1$ \\
\hline
\end{tabular}


Table 50: L3.

\begin{tabular}{|c|c|c|c|c|c|c|c|c|c|c|c|c|}
\hline \multirow{2}{*}{$\begin{array}{l}\text { Date } \\
(1930)\end{array}$} & \multicolumn{2}{|c|}{$\begin{array}{l}\text { Size } \\
\text { of fish. }\end{array}$} & \multicolumn{2}{|c|}{$\begin{array}{l}\text { Growth } \\
\text { per } \\
\text { period. }\end{array}$} & \multirow{2}{*}{$\begin{array}{l}\text { Weight } \\
\text { of food } \\
\text { per } \\
\text { period. } \\
\text { (gm.) }\end{array}$} & \multirow[t]{2}{*}{$\begin{array}{l}\text { No. of } \\
\text { days } \\
\text { in } \\
\text { period. }\end{array}$} & \multirow{2}{*}{$\begin{array}{c}\text { Average } \\
\text { weight } \\
\text { of food } \\
\text { per day. } \\
\text { (gm.) }\end{array}$} & \multirow{2}{*}{$\begin{array}{c}\text { Ratio of } \\
\text { food per } \\
\text { day/ } \\
\text { /average } \\
\text { body-wt. } \\
\text { for } \\
\text { period. }\end{array}$} & \multirow{2}{*}{$\begin{array}{c}\text { Total } \\
\text { wt. of } \\
\text { food } \\
\text { to date. } \\
\text { (gm.) }\end{array}$} & \multirow{2}{*}{$\begin{array}{l}\text { No. of } \\
\text { days } \\
\text { since } \\
\text { com- } \\
\text { mence- } \\
\text { ment of } \\
\text { expt. }\end{array}$} & \multicolumn{2}{|c|}{$\begin{array}{l}\text { Cumulative } \\
\text { growth. }\end{array}$} \\
\hline & $\begin{array}{l}\text { Lth. } \\
\text { (cm.) }\end{array}$ & $\begin{array}{l}\text { Wt. } \\
\text { (gm.) }\end{array}$ & $\begin{array}{l}\text { Lth. } \\
\text { (cm.) }\end{array}$ & $\begin{array}{c}\text { Wt. } \\
\text { (gm.) }\end{array}$ & & & & & & & $\begin{array}{l}\text { Lth. } \\
\text { (cm.) }\end{array}$ & $\begin{array}{l}\text { Wt. } \\
\text { (gm.) }\end{array}$ \\
\hline May 12 & $21 \cdot 5$ & $90 \cdot 3$ & - & - & - & - & - & - & - & - & - & - \\
\hline , 26 & $21 \cdot 5$ & $83 \cdot 5$ & nil & $-6 \cdot 8$ & $5 \cdot 4$ & 14 & $0 \cdot 39$ & $0 \cdot 004$ & $5 \cdot 4$ & 14 & nil & $-6 \cdot 8$ \\
\hline June 9 & $21 \cdot 5$ & $82 \cdot 4$ & nil & $-1 \cdot 1$ & $12 \cdot 5$ & 14 & $0 \cdot 89$ & 0.011 & $17 \cdot 9$ & 28 & nil & $-7 \cdot 9$ \\
\hline,$\quad 23$ & $21 \cdot 5$ & $81 \cdot 1$ & nil & $-1 \cdot 3$ & $15 \cdot 1$ & 14 & 1.08 & 0.013 & $33 \cdot 0$ & 42 & nil & $-9 \cdot 2$ \\
\hline July 7 & $21 \cdot 5$ & $81 \cdot 1$ & nil & nil & $16 \cdot 5$ & 14 & $1 \cdot 18$ & 0.014 & $49 \cdot 5$ & 56 & nil & $-9 \cdot 2$ \\
\hline , $\quad 21$ & $21 \cdot 5$ & $79 \cdot 1$ & nil & $-2 \cdot 0$ & $16 \cdot 5$ & 14 & $1 \cdot 18$ & 0.014 & $66 \cdot 0$ & 70 & nil & $-11 \cdot 2$ \\
\hline Aug. 4 & $21 \cdot 5$ & $79 \cdot 8$ & nil & $0 \cdot 7$ & $18 \cdot 5$ & 14 & $1 \cdot 32$ & $0 \cdot 017$ & $84 \cdot 5$ & 84 & nil & $-10 \cdot 5$ \\
\hline , 18 & $21 \cdot 5$ & $78 \cdot 7$ & nil & $-1 \cdot 1$ & $17 \cdot 9$ & 14 & $1 \cdot 28$ & $0 \cdot 016$ & $102 \cdot 4$ & 98 & nil & $-11 \cdot 6$ \\
\hline Sept. 1 & $21 \cdot 5$ & $77 \cdot 8$ & nil & -0.9 & $18 \cdot 0$ & 14 & $1 \cdot 29$ & $0 \cdot 017$ & $120 \cdot 4$ & 112 & nil & $-12 \cdot 5$ \\
\hline,$\quad 15$ & $21 \cdot 5$ & $77 \cdot 5$ & nil & $-0 \cdot 3$ & $21 \cdot 2$ & 14 & $1 \cdot 51$ & $0 \cdot 019$ & $141 \cdot 6$ & 126 & nil & $-12 \cdot 8$ \\
\hline , $\quad 29$ & $21 \cdot 6$ & $74 \cdot 4$ & $0 \cdot 1$ & $-3 \cdot 1$ & $14 \cdot 4$ & 14 & 1.03 & $0 \cdot 014$ & $156 \cdot 0$ & 140 & $0 \cdot 1$ & $-15 \cdot 9$ \\
\hline Oct. 13 & $21 \cdot 6$ & $75 \cdot 1$ & nil & $0 \cdot 7$ & $14 \cdot 8$ & 14 & $1 \cdot 06$ & $0 \cdot 014$ & $170 \cdot 8$ & 154 & $0 \cdot 1$ & $-15 \cdot 2$ \\
\hline, $2 \quad 27$ & $21 \cdot 6$ & $75 \cdot 5$ & nil & $0 \cdot 4$ & $14 \cdot 1$ & 14 & 1.01 & 0.013 & $184 \cdot 9$ & 168 & $0 \cdot 1$ & $-14 \cdot 8$ \\
\hline Nov. 10 & $21 \cdot 6$ & $76 \cdot 3$ & nil & $0 \cdot 8$ & $12 \cdot 6$ & 14 & $0 \cdot 90$ & 0.014 & $197 \cdot 5$ & 182 & $0 \cdot 1$ & $-14 \cdot 0$ \\
\hline 24 & $21 \cdot 6$ & $78 \cdot 6$ & nil & $2 \cdot 3$ & $11 \cdot 8$ & 14 & 0.84 & $0 \cdot 011$ & $209 \cdot 3$ & 196 & $0 \cdot 1$ & $-11 \cdot 7$ \\
\hline
\end{tabular}

(a)

\begin{tabular}{|c|c|c|}
\hline May 12 & $18 \cdot 5$ & $65 \cdot 8$ \\
\hline & 18.5 & $64 \cdot 8$ \\
\hline June 9 & 18.5 & $63 \cdot 8$ \\
\hline$\Rightarrow \quad 23$ & 18.5 & $62 \cdot 2$ \\
\hline aly & 18.5 & $62 \cdot 1$ \\
\hline & 18.5 & 62 \\
\hline & $18 \cdot 6$ & $64 \cdot($ \\
\hline & $18 \cdot 6$ & $63 \cdot 5$ \\
\hline & $18 \cdot 7$ & $63 \cdot c$ \\
\hline
\end{tabular}

Table 51: L4 (a and b).

(b)

Sept. $15 \quad 24.4 \quad 149.6$ $\begin{array}{llll},, & 29 & 24.4 & 142.8\end{array}$ $\begin{array}{lll}\text { Oct. } 13 \quad 24.4 & 145 \cdot 1\end{array}$ $\begin{array}{llll}, 2 & 27 & 24.4 & 147.2\end{array}$ $\begin{array}{lll}\text { Nov. } 10 \quad 24 \cdot 6 & 147 \cdot 2\end{array}$ $\begin{array}{llll}\text {, } 24 & 24.7 & 149.5\end{array}$

$\begin{array}{lrrr}\overline{\text { nil }} & -\overline{0 \cdot 7} & \overline{7 \cdot 6} & \overline{14} \\ \text { nil } & -1 \cdot 0 & 8 \cdot 7 & 14 \\ \text { nil } & -1 \cdot 6 & 9 \cdot 9 & 14 \\ \text { nil } & -0 \cdot 1 & 11 \cdot 5 & 14 \\ \text { nil } & 0 \cdot 4 & 11 \cdot 5 & 14 \\ 0 \cdot 1 & 2 \cdot 1 & 12 \cdot 0 & 14 \\ \text { nil } & -1 \cdot 1 & 9 \cdot 9 & 14 \\ 0 \cdot 1 & -0 \cdot 5 & 11 \cdot 1 & 14\end{array}$

$-\overline{0} 54$
$0 \cdot 62$
$0 \cdot 71$
$0 \cdot 82$
$0 \cdot 82$
$0 \cdot 86$
$0 \cdot 71$
$0 \cdot 79$

$0 . \overline{0}$
0.010
0.011
0.013
0.013
0.014
0.011
0.012

$\overline{7 \cdot 6}$ $16 \cdot 3$, $26 \cdot 2$ $37 \cdot 7$ $49 \cdot 2$ $61 \cdot 2$

$71 \cdot 1$ $82 \cdot 2$

$\overline{14}$
28
42
56
70
84
98

$$
\begin{array}{ll}
\overline{\text { nil }} & -\overline{0 \cdot 7} \\
\text { nil } & -1 \cdot 7 \\
\text { nil } & -3 \cdot 3 \\
\text { nil } & -3 \cdot 4 \\
\text { nil } & -3 \cdot 0 \\
0 \cdot 1 & -0 \cdot 9 \\
0 \cdot 1 & -2 \cdot 0 \\
0 \cdot 2 & -2 \cdot 5
\end{array}
$$

$\begin{array}{rrrrrrrrrr}\overline{\text { nil }} & -\overline{6 \cdot 3} & \overline{9 \cdot 4} & \overline{14} & \overline{0} \overline{67} & 0 \cdot \overline{005} & \overline{9 \cdot 4} & \overline{14} & \overline{\text { nil }} & -\overline{6 \cdot 8} \\ \text { nil } & 2 \cdot 3 & 15 \cdot 4 & 14 & 1 \cdot 10 & 0 \cdot 008 & 24 \cdot 8 & 28 & \text { nil } & -4 \cdot 5 \\ \text { nil } & 2 \cdot 1 & 13 \cdot 2 & 14 & 0 \cdot 94 & 0 \cdot 006 & 38 \cdot 0 & 42 & \text { nil } & -2 \cdot 4 \\ 0 \cdot 2 & \text { nil } & 12 \cdot 2 & 14 & 0 \cdot 87 & 0 \cdot 006 & 50 \cdot 2 & 56 & 0 \cdot 2 & -2 \cdot 4 \\ 0 \cdot 1 & 2 \cdot 3 & 12 \cdot 3 & 14 & 0 \cdot 88 & 0 \cdot 006 & 62 \cdot 5 & 70 & 0 \cdot 3 & -0 \cdot 1\end{array}$


TABLE 52.

Summarised Data: Maintenance Requirements of Male Plaice.

\begin{tabular}{|c|c|c|c|c|c|c|c|c|c|}
\hline \multirow{2}{*}{$\begin{array}{l}\text { Fish } \\
\text { No. }\end{array}$} & \multicolumn{2}{|c|}{$\begin{array}{c}\text { Initial } \\
\text { size. }\end{array}$} & \multicolumn{2}{|c|}{$\begin{array}{l}\text { Final } \\
\text { size. }\end{array}$} & \multicolumn{2}{|c|}{ Growth. } & \multirow{2}{*}{$\begin{array}{c}\text { Days } \\
\text { in } \\
\text { period. }\end{array}$} & \multirow{2}{*}{$\begin{array}{c}\text { Average } \\
\text { weight } \\
\text { of food } \\
\text { per day. } \\
\text { (gm.) }\end{array}$} & \multirow{2}{*}{$\begin{array}{c}\text { Ratio } \\
\text { Food per } \\
\text { day/ } \\
\text { /mid } \\
\text { body- } \\
\text { weight } \\
\text { for period. }\end{array}$} \\
\hline & $\begin{array}{l}\text { Lth. } \\
\text { (cm.) }\end{array}$ & $\begin{array}{l}\text { Wt. } \\
\text { (gm.) }\end{array}$ & $\begin{array}{l}\text { Lth. } \\
\text { (em.) }\end{array}$ & $\begin{array}{l}\text { Wt. } \\
\text { (gm.) }\end{array}$ & $\begin{array}{l}\text { Lth. } \\
\text { (cm.) }\end{array}$ & $\begin{array}{c}\text { Wt. } \\
\text { (gm.) }\end{array}$ & & & \\
\hline L1 & $17 \cdot 9$ & $62 \cdot 2$ & $18 \cdot 1$ & $57 \cdot 5$ & $0 \cdot 2$ & $-4 \cdot 7$ & 182 & $0 \cdot 86$ & $0 \cdot 015$ \\
\hline L2 & $20 \cdot 0$ & $65 \cdot 0$ & $20 \cdot 2$ & $70 \cdot 3$ & $0 \cdot 2$ & $5 \cdot 3$ & 168 & $1 \cdot 03$ & $0 \cdot 015$ \\
\hline L3 & $21 \cdot 5$ & $90 \cdot 3$ & $21 \cdot 6$ & $76 \cdot 3$ & $0 \cdot 1$ & $-14 \cdot 0$ & 182 & $1 \cdot 09$ & $0 \cdot 013$ \\
\hline \multirow{2}{*}{ L4 } & (a) 18.5 & $65 \cdot 5$ & $18 \cdot 7$ & $63 \cdot 0$ & $0 \cdot 2$ & $-2 \cdot 5$ & 112 & $0 \cdot 74$ & $0 \cdot 012$ \\
\hline & (b) $24 \cdot 4$ & $149 \cdot 6$ & $24 \cdot 6$ & $147 \cdot 2$ & $0 \cdot 2$ & $-2 \cdot 4$ & 56 & $0 \cdot 89$ & $0 \cdot 006$ \\
\hline
\end{tabular}


TABLES 53-56.

Mamntenance Requirements of Female Platce.

TABLE 53: L5.

\begin{tabular}{|c|c|c|c|c|c|c|c|c|c|c|c|c|}
\hline \multirow{2}{*}{$\begin{array}{l}\text { Date } \\
(1930)\end{array}$} & \multicolumn{2}{|c|}{$\begin{array}{l}\text { Size } \\
\text { of fish. }\end{array}$} & \multicolumn{2}{|c|}{$\begin{array}{c}\text { Growth } \\
\text { per } \\
\text { period. }\end{array}$} & \multirow{2}{*}{$\begin{array}{c}\text { Weight } \\
\text { of food } \\
\text { per } \\
\text { period. } \\
\text { (gm.) }\end{array}$} & \multirow{2}{*}{$\begin{array}{c}\text { No. of } \\
\text { days } \\
\text { in } \\
\text { period. }\end{array}$} & \multirow{2}{*}{$\begin{array}{c}\text { Average } \\
\text { weight } \\
\text { of food } \\
\text { per day. } \\
\text { (gm.) }\end{array}$} & \multirow{2}{*}{$\begin{array}{l}\text { Ratio of } \\
\text { food per } \\
\text { day/ } \\
\text { /average } \\
\text { body-wt. } \\
\text { for } \\
\text { period. }\end{array}$} & \multirow{2}{*}{$\begin{array}{c}\text { Total } \\
\text { wt. of } \\
\text { food } \\
\text { to date. } \\
\text { (gm.) }\end{array}$} & \multirow{2}{*}{$\begin{array}{l}\text { No. of } \\
\text { days } \\
\text { since } \\
\text { com- } \\
\text { mence- } \\
\text { ment of } \\
\text { expt. }\end{array}$} & \multicolumn{2}{|c|}{$\begin{array}{l}\text { Cumulative } \\
\text { growth. }\end{array}$} \\
\hline & $\begin{array}{l}\text { Lth. } \\
\text { (em.) }\end{array}$ & $\begin{array}{l}\text { Wt. } \\
\text { (gm.) }\end{array}$ & $\begin{array}{l}\text { Lth. } \\
\text { (em.) }\end{array}$ & $\begin{array}{l}\text { Wt. } \\
\text { (gm.) }\end{array}$ & & & & & & & $\begin{array}{l}\text { Lth. } \\
(\mathrm{cm} .)\end{array}$ & $\begin{array}{l}\text { Wt. } \\
\text { (gm.) }\end{array}$ \\
\hline May 12 & $14 \cdot 7$ & $28 \cdot 9$ & - & - & - & - & - & - & - & - & - & - \\
\hline,$\quad 26$ & $14 \cdot 7$ & $28 \cdot 6$ & nil & $-0 \cdot 3$ & $5 \cdot 2$ & 14 & $0 \cdot 37$ & 0.013 & $5 \cdot 2$ & 14 & nil & $-0 \cdot 3$ \\
\hline June 9 & $14 \cdot 7$ & $27 \cdot 8$ & nil & -0.8 & $7 \cdot 0$ & 14 & 0.50 & $0 \cdot 018$ & $12 \cdot 2$ & 28 & nil & $-1 \cdot 1$ \\
\hline,$\quad 23$ & $14 \cdot 7$ & $26 \cdot 6$ & nil & $-1 \cdot 2$ & $7 \cdot 8$ & 14 & $0 \cdot 56$ & $0 \cdot 021$ & $20 \cdot 0$ & 42 & nil & $-2 \cdot 3$ \\
\hline aly 7 & $14 \cdot 7$ & $25 \cdot 7$ & nil & -0.9 & $9 \cdot 9$ & 14 & $0 \cdot 71$ & $0 \cdot 027$ & $29 \cdot 9$ & 56 & nil & $-3 \cdot 2$ \\
\hline , 21 & $14 \cdot 7$ & $25 \cdot 3$ & nil & -0.4 & $11 \cdot 5$ & 14 & 0.82 & 0.032 & $41 \cdot 4$ & 70 & nil & $-3 \cdot 6$ \\
\hline ug. 4 & $14 \cdot 7$ & $25 \cdot 7$ & nil & 0.4 & $12 \cdot 0$ & 14 & $0 \cdot 86$ & 0.034 & $53 \cdot 4$ & 84 & nil & $-3 \cdot 2$ \\
\hline , 18 & $14 \cdot 7$ & $25 \cdot 9$ & nil & $0 \cdot 2$ & $11 \cdot 8$ & 14 & $0 \cdot 84$ & $0 \cdot 033$ & $65 \cdot 2$ & 98 & nil & $-3 \cdot 0$ \\
\hline Sept. 1 & $14 \cdot 7$ & $26 \cdot 0$ & nil & $0 \cdot 1$ & $11 \cdot 6$ & 14 & $0 \cdot 83$ & 0.032 & $76 \cdot 8$ & 112 & nil & $-2 \cdot 9$ \\
\hline , 15 & $14 \cdot 7$ & $26 \cdot 1$ & nil & $0 \cdot 1$ & $16 \cdot 2$ & 14 & $1 \cdot 16$ & $0 \cdot 045$ & $93 \cdot 0$ & 126 & nil & $-2 \cdot 8$ \\
\hline,$\quad 29$ & $14 \cdot 7$ & $25 \cdot 8$ & nil & $-0 \cdot 3$ & $11 \cdot 0$ & 14 & $0 \cdot 79$ & $0 \cdot 031$ & $104 \cdot 0$ & 140 & nil & $-3 \cdot 1$ \\
\hline Oet. 13 & $14 \cdot 7$ & $27 \cdot 7$ & nil & $1 \cdot 9$ & $14 \cdot 2$ & 14 & 1.01 & $0 \cdot 038$ & $118 \cdot 2$ & 154 & nil & $-1 \cdot 2$ \\
\hline, , 27 & $14 \cdot 8$ & $28 \cdot 7$ & 0.1 & $1 \cdot 0$ & $12 \cdot 3$ & 14 & $0 \cdot 88$ & $0 \cdot 034$ & $130 \cdot 5$ & 168 & $0 \cdot 1$ & $-0 \cdot 2$ \\
\hline Nov. 10 & $14 \cdot 8$ & $29 \cdot 1$ & nil & $0 \cdot 4$ & $11 \cdot 2$ & 14 & $0 \cdot 80$ & $0 \cdot 028$ & $141 \cdot 7$ & 182 & $0 \cdot 1$ & $0 \cdot 2$ \\
\hline,$\quad 24$ & $14 \cdot 9$ & $31 \cdot 3$ & $0 \cdot 1$ & $2 \cdot 2$ & $10 \cdot 9$ & 14 & $0 \cdot 78$ & $0 \cdot 026$ & $152 \cdot 6$ & 196 & $0 \cdot 2$ & $2 \cdot 4$ \\
\hline
\end{tabular}

TABLE 54: L6 (a and b).

(a)

\begin{tabular}{|c|c|c|c|c|c|c|c|c|c|c|c|c|}
\hline May 12 & $18 \cdot 0$ & $69 \cdot 9$ & - & - & - & - & - & - & - & - & - & - \\
\hline,$\quad 26$ & $18 \cdot 0$ & $62 \cdot 9$ & nil & $-7 \cdot 0$ & $6 \cdot 1$ & 14 & $0 \cdot 44$ & $0 \cdot 007$ & $6 \cdot 1$ & 14 & nil & $-7 \cdot 0$ \\
\hline June 9 & $18 \cdot 0$ & $61 \cdot 3$ & nil & $-1 \cdot 6$ & $10 \cdot 7$ & 14 & 0.76 & 0.012 & $16 \cdot 8$ & 28 & nil & $-8 \cdot 6$ \\
\hline & $18 \cdot 0$ & $59 \cdot 8$ & nil & $-1 \cdot 5$ & $11 \cdot 8$ & 14 & 0.84 & 0.014 & $28 \cdot 6$ & 42 & nil & $-10 \cdot 1$ \\
\hline July 7 & $18 \cdot 0$ & $61 \cdot 1$ & nil & $1 \cdot 3$ & $14 \cdot 0$ & 14 & 1.00 & 0.017 & $42 \cdot 6$ & 56 & nil & -8.8 \\
\hline,$\quad 21$ & $18 \cdot 0$ & $62 \cdot 2$ & nil & $1 \cdot 1$ & $12 \cdot 4$ & 14 & $0 \cdot 89$ & 0.013 & $55 \cdot 0$ & 70 & nil & $-7 \cdot 7$ \\
\hline Aug. 4 & $18 \cdot 0$ & 63.8 & nil & $1 \cdot 6$ & $12 \cdot 0$ & 14 & $0 \cdot 86$ & $0 \cdot 014$ & $67 \cdot 0$ & 84 & nil & $-6 \cdot 1$ \\
\hline,$\quad 18$ & $18 \cdot 0$ & $65 \cdot 3$ & nil & $1 \cdot 5$ & $10 \cdot 5$ & 14 & $0 \cdot 75$ & 0.012 & $77 \cdot 5$ & 98 & nil & $-4 \cdot 6$ \\
\hline Sept. 1 & $18 \cdot 0$ & $64 \cdot 6$ & nil & $-0 \cdot 7$ & $7 \cdot 5$ & 14 & 0.54 & $0 \cdot 008$ & $85 \cdot 0$ & 112 & nil & $-5 \cdot 3$ \\
\hline (b) & & & & & & & & & & & & \\
\hline Sept. 29 & $17 \cdot 3$ & $56 \cdot 2$ & - & - & - & - & - & - & - & 一 & - & - \\
\hline Oet. 13 & $17 \cdot 4$ & $60 \cdot 2$ & $0 \cdot 1$ & $4 \cdot 0$ & $8 \cdot 5$ & 14 & 0.61 & $0 \cdot 010$ & 85 & 14 & $0 \cdot 1$ & $4 \cdot 0$ \\
\hline,$\quad 27$ & $17 \cdot 6$ & $64 \cdot 3$ & $0 \cdot 2$ & $4 \cdot 1$ & $4 \cdot 6$ & 14 & $0 \cdot 33$ & $0 \cdot 005$ & $13 \cdot 1$ & 28 & $0 \cdot 3$ & $8 \cdot 1$ \\
\hline Nov. 10 & $17 \cdot 7$ & $64 \cdot 9$ & $0 \cdot 1$ & $0 \cdot 6$ & $0 \cdot 5$ & 14 & $0 \cdot 03$ & - & $13 \cdot 6$ & 42 & $0 \cdot 4$ & $8 \cdot 7$ \\
\hline 24 & $17 \cdot 8$ & $67 \cdot 7$ & $0 \cdot 1$ & $2 \cdot 8$ & $3 \cdot 0$ & 14 & $0 \cdot 21$ & 0.003 & $16 \cdot 6$ & 56 & $0 \cdot 5$ & $11 \cdot 5$ \\
\hline
\end{tabular}


TABLE 55: L7.

\begin{tabular}{|c|c|c|c|c|c|c|c|c|c|c|c|c|}
\hline \multirow{2}{*}{$\begin{array}{c}\text { Date } \\
\text { (1930) }\end{array}$} & \multicolumn{2}{|c|}{$\begin{array}{c}\text { Size } \\
\text { of fish. }\end{array}$} & \multicolumn{2}{|c|}{$\begin{array}{l}\text { Growth } \\
\text { per } \\
\text { period. }\end{array}$} & \multirow{2}{*}{$\begin{array}{l}\text { Weight } \\
\text { of food } \\
\text { per } \\
\text { period. } \\
\text { (gm.) }\end{array}$} & \multirow[t]{2}{*}{$\begin{array}{c}\text { No. of } \\
\text { days } \\
\text { in } \\
\text { period. }\end{array}$} & \multirow{2}{*}{$\begin{array}{c}\text { Average } \\
\text { weight } \\
\text { of food } \\
\text { per day. } \\
\text { (gm.) }\end{array}$} & \multirow{2}{*}{$\begin{array}{c}\text { Ratio of } \\
\text { food per } \\
\text { day/ } \\
\text { /average } \\
\text { body-wt. } \\
\text { for } \\
\text { period. }\end{array}$} & \multirow{2}{*}{$\begin{array}{c}\text { Total } \\
\text { wt. of } \\
\text { food } \\
\text { to date. } \\
\text { (gm.) }\end{array}$} & \multirow{2}{*}{$\begin{array}{l}\text { No. of } \\
\text { days } \\
\text { since } \\
\text { com- } \\
\text { mence- } \\
\text { ment of } \\
\text { expt. }\end{array}$} & \multicolumn{2}{|c|}{$\begin{array}{l}\text { Cumulative } \\
\text { growth. }\end{array}$} \\
\hline & $\begin{array}{l}\text { Lth. } \\
\text { (em.) }\end{array}$ & $\begin{array}{l}\text { Wt. } \\
\text { (gm.) }\end{array}$ & $\begin{array}{l}\text { Lth. } \\
\text { (em.) }\end{array}$ & $\begin{array}{l}\text { Wt. } \\
\text { (gm.) }\end{array}$ & & & & & & & $\begin{array}{l}\text { Lth. } \\
\text { (cm.) }\end{array}$ & $\begin{array}{l}\text { Wt. } \\
\text { (gm.) }\end{array}$ \\
\hline June 23 & $18 \cdot 0$ & $58 \cdot 5$ & - & - & - & 一 & - & - & - & - & - & \\
\hline July 7 & I8.1 & $57 \cdot 1$ & $0 \cdot 1$ & $-1 \cdot 4$ & $11 \cdot 2$ & 14 & $0 \cdot 80$ & 0.014 & $11 \cdot 2$ & 14 & $0 \cdot 1$ & $-1 \cdot 4$ \\
\hline,$\quad 21$ & $18 \cdot 1$ & $57 \cdot 4$ & nil & $0 \cdot 3$ & $12 \cdot 6$ & 14 & $0 \cdot 90$ & $0 \cdot 016$ & $23 \cdot 8$ & 28 & $0 \cdot 1$ & $-1 \cdot 1$ \\
\hline Aug. 4 & $18 \cdot 1$ & $58 \cdot 1$ & nil & $0 \cdot 7$ & $12 \cdot 6$ & 14 & $0 \cdot 90$ & $0 \cdot 016$ & $36 \cdot 4$ & 42 & $0 \cdot 1$ & $-0 \cdot 4$ \\
\hline , 18 & $18 \cdot 1$ & $57 \cdot 9$ & nil & -0.2 & $9 \cdot 9$ & 14 & $0 \cdot 71$ & 0.012 & $46 \cdot 3$ & 56 & $0 \cdot 1$ & -0.6 \\
\hline Sept. 1 & $18 \cdot 1$ & $57 \cdot 8$ & nil & $-0 \cdot 1$ & $10 \cdot 1$ & 14 & $0 \cdot 72$ & 0.012 & $56 \cdot 4$ & 70 & $0 \cdot 1$ & -0.7 \\
\hline , 15 & $18 \cdot 1$ & $59 \cdot 2$ & nil & $1 \cdot 4$ & $19 \cdot 4$ & 14 & $1 \cdot 39$ & 0.024 & $75 \cdot 8$ & 84 & $0 \cdot 1$ & $0 \cdot 7$ \\
\hline , 29 & $18 \cdot 2$ & $59 \cdot 2$ & $0 \cdot 1$ & nil & $8 \cdot 8$ & 14 & $0 \cdot 63$ & 0.011 & $84 \cdot 6$ & 98 & $0 \cdot 2$ & 0.7 \\
\hline Oct. 13 & $18 \cdot 2$ & $59 \cdot 2$ & nil & nil & $8 \cdot 1$ & 14 & $0 \cdot 58$ & 0.010 & $92 \cdot 7$ & 112 & $0 \cdot 2$ & 0.7 \\
\hline , 27 & $18 \cdot 2$ & $60 \cdot 2$ & nil & $1 \cdot 0$ & $8 \cdot 1$ & 14 & $0 \cdot 58$ & $0 \cdot 010$ & $100 \cdot 8$ & 126 & $0 \cdot 2$ & $1 \cdot 7$ \\
\hline Nov. 10 & $18 \cdot 2$ & $60 \cdot 4$ & nil & $0 \cdot 2$ & $7 \cdot 1$ & 14 & 0.51 & 0.008 & $107 \cdot 9$ & 140 & $0 \cdot 2$ & $1 \cdot 9$ \\
\hline , 24 & $18 \cdot 2$ & $61 \cdot 0$ & nil & $0 \cdot 6$ & $7 \cdot 0$ & 14 & 0.50 & 0.008 & $114 \cdot 9$ & 154 & $0 \cdot 2$ & $2 \cdot 5$ \\
\hline
\end{tabular}

TABLe 56: L8.

\begin{tabular}{|c|c|c|c|c|c|c|c|c|c|c|c|c|c|}
\hline May & 12 & 18.8 & $56 \cdot 8$ & - & - & - & 一 & - & - & - & - & - & - \\
\hline & 26 & 18.8 & $56 \cdot 8$ & nil & nil & $7 \cdot 9$ & 14 & 0.56 & 0.010 & $7 \cdot 9$ & 14 & nil & nil \\
\hline June & 9 & $18 \cdot 8$ & $50 \cdot 9$ & nil & $-5 \cdot 9$ & $8 \cdot 7$ & 14 & 0.62 & 0.012 & $16 \cdot 6$ & 28 & nil & $-5 \cdot 9$ \\
\hline & 23 & $18 \cdot 8$ & $51 \cdot 3$ & nil & 0.4 & $14 \cdot 8$ & 14 & $1 \cdot 06$ & 0.021 & $31 \cdot 4$ & 42 & nil & -5.5 \\
\hline July & 7 & $18 \cdot 8$ & $50 \cdot 8$ & nil & -0.5 & $14 \cdot 6$ & 14 & $1 \cdot 04$ & 0.020 & 46.0 & 56 & nil & -6.0 \\
\hline & 21 & 18.8 & $52 \cdot 5$ & nil & $1 \cdot 7$ & $15 \cdot 1$ & 14 & 1.08 & 0.021 & $61 \cdot 1$ & 70 & nil & $-4 \cdot 3$ \\
\hline Aug. & 4 & 18.8 & $52 \cdot 6$ & nil & $0 \cdot 1$ & $13 \cdot 4$ & 14 & $0 \cdot 96$ & 0.018 & $74 \cdot 5$ & 84 & nil & $-4 \cdot 2$ \\
\hline & 18 & 18.8 & 53.0 & nil & $0 \cdot 4$ & $13 \cdot 4$ & 14 & 0.96 & 0.018 & $87 \cdot 9$ & 98 & nil & $-3 \cdot 8$ \\
\hline Sept. & 1 & $18 \cdot 8$ & $53 \cdot 0$ & nil & nil & $13 \cdot 0$ & 14 & $0 \cdot 93$ & $0 \cdot 018$ & $100 \cdot 9$ & 112 & nil & $-3 \cdot 8$ \\
\hline , & 15 & $18 \cdot 8$ & $54 \cdot 7$ & nil & $1 \cdot 7$ & $19 \cdot 3$ & 14 & $1 \cdot 38$ & $0 \cdot 026$ & $120 \cdot 2$ & 126 & nil & $-2 \cdot 1$ \\
\hline & 29 & $18 \cdot 9$ & $55 \cdot 1$ & $0 \cdot 1$ & 0.4 & $11 \cdot 2$ & 14 & $0 \cdot 80$ & 0.014 & $131 \cdot 3$ & 140 & $0 \cdot 1$ & $-1 \cdot 7$ \\
\hline Oct. & 13 & $18 \cdot 9$ & $55 \cdot 1$ & nil & nil & $8 \cdot 7$ & 14 & $0 \cdot 62$ & 0.011 & $140 \cdot 9$ & 154 & $0 \cdot 1$ & -1.7 \\
\hline & 27 & 18.9 & $55 \cdot 1$ & nil & nil & $8 \cdot 7$ & 14 & $0 \cdot 62$ & 0.011 & $148 \cdot 7$ & 168 & $0 \cdot 1$ & $-1 \cdot 7$ \\
\hline Nov. & 10 & 18.9 & $55 \cdot 8$ & nil & $0 \cdot 7$ & 8.7 & 14 & $0 \cdot 62$ & $0 \cdot 011$ & $157 \cdot 4$ & 182 & $0 \cdot 1$ & -1.0 \\
\hline , & 24 & $18 \cdot 9$ & $57 \cdot 8$ & nil & $2 \cdot 0$ & $8 \cdot 0$ & 14 & 0.57 & 0.010 & $165 \cdot 4$ & 196 & $0 \cdot 1$ & $1 \cdot 0$ \\
\hline
\end{tabular}


TABLE 57.

Summarised Data: Maintenance Requirements of Female Plaice.

\begin{tabular}{|c|c|c|c|c|c|c|c|c|c|}
\hline \multirow[b]{2}{*}{$\begin{array}{l}\text { Fish } \\
\text { No. }\end{array}$} & \multicolumn{2}{|c|}{$\begin{array}{c}\text { Initial } \\
\text { size. }\end{array}$} & \multicolumn{2}{|c|}{$\begin{array}{c}\text { Final } \\
\text { size. }\end{array}$} & \multicolumn{2}{|c|}{ Growth. } & \multirow[b]{2}{*}{$\begin{array}{l}\text { Days } \\
\text { in } \\
\text { period. }\end{array}$} & \multirow{2}{*}{$\begin{array}{c}\text { Average } \\
\text { weight } \\
\text { of food } \\
\text { per day. } \\
\text { (gm.) }\end{array}$} & \multirow{2}{*}{$\begin{array}{c}\text { Ratio } \\
\text { Food per } \\
\text { day/ } \\
\text { /mid } \\
\text { body. } \\
\text { weight } \\
\text { per period }\end{array}$} \\
\hline & $\begin{array}{l}\text { Lth. } \\
\text { (cm.) }\end{array}$ & $\begin{array}{c}\text { Wt. } \\
\text { (gm.) }\end{array}$ & $\begin{array}{l}\text { Lth. } \\
\text { (cm.) }\end{array}$ & $\begin{array}{l}\text { Wt. } \\
\text { (gm.) }\end{array}$ & $\begin{array}{l}\text { Lth. } \\
\text { (em.) }\end{array}$ & $\begin{array}{l}\text { Wt. } \\
\text { (gm.) }\end{array}$ & & & \\
\hline L5 & $14 \cdot 7$ & $28 \cdot 9$ & $14 \cdot 8$ & $29 \cdot 1$ & $0 \cdot 1$ & $0 \cdot 2$ & 182 & $0 \cdot 78$ & $0 \cdot 027$ \\
\hline \multirow{2}{*}{ L6 } & (a) $18 \cdot 0$ & $69 \cdot 9$ & $18 \cdot 0$ & $64 \cdot 6$ & nil & $-5 \cdot 3$ & 112 & $0 \cdot 76$ & $0 \cdot 011$ \\
\hline & (b) $17 \cdot 3$ & $56 \cdot 2$ & $17 \cdot 7$ & $64 \cdot 9$ & $0 \cdot 4$ & $8 \cdot 7$ & 42 & $0 \cdot 32$ & 0.005 \\
\hline L7 & $18 \cdot 0$ & $58 \cdot 5$ & $18 \cdot 2$ & $60 \cdot 4$ & $0 \cdot 2$ & $1 \cdot 9$ & 140 & $0 \cdot 77$ & $0 \cdot 013$ \\
\hline L8 & $18 \cdot 8$ & $56 \cdot 8$ & $18 \cdot 9$ & $55 \cdot 8$ & $0 \cdot 1$ & $-1 \cdot 0$ & 182 & $0 \cdot 86$ & 0.015 \\
\hline
\end{tabular}


TABLE 58.

Summarised Data: Maximum Requirements and Growth of Male and Female Plaice.

\begin{tabular}{|c|c|c|c|c|c|c|c|c|c|c|c|c|c|}
\hline \multirow{2}{*}{$\begin{array}{l}\text { Fish } \\
\text { No. }\end{array}$} & \multirow[t]{2}{*}{ Sex. } & \multicolumn{2}{|c|}{$\begin{array}{l}\text { Initial } \\
\text { size. }\end{array}$} & \multicolumn{2}{|c|}{$\begin{array}{c}\text { Final } \\
\text { size. }\end{array}$} & \multicolumn{2}{|c|}{ Growth. } & \multicolumn{2}{|c|}{ Period. } & \multirow{2}{*}{$\begin{array}{c}\text { Days } \\
\text { in } \\
\text { Period. }\end{array}$} & \multirow{2}{*}{$\begin{array}{l}\text { Total } \\
\text { food } \\
\text { per the } \\
\text { period. } \\
\text { (gm.) }\end{array}$} & \multirow{2}{*}{$\begin{array}{c}\text { Average } \\
\text { weight } \\
\text { of food } \\
\text { per day } \\
\text { for the } \\
\text { period } \\
\text { (gm.) }\end{array}$} & \multirow{2}{*}{$\begin{array}{l}\text { Gm. of } \\
\text { food per } \\
1.0 \mathrm{gm} . \\
\text { increase } \\
\text { in weight } \\
\text { of fish. }\end{array}$} \\
\hline & & $\begin{array}{l}\text { Lth. } \\
\text { (em.) }\end{array}$ & $\begin{array}{l}\text { Wt. } \\
\text { (gm.) }\end{array}$ & $\begin{array}{l}\text { Lth. } \\
\text { (cm.) }\end{array}$ & $\begin{array}{l}\text { Wt. } \\
\text { (gm.) }\end{array}$ & $\begin{array}{l}\text { Lth. } \\
\text { (cm.) }\end{array}$ & $\begin{array}{l}\text { Wt. } \\
\text { (gm.) }\end{array}$ & From & To & & & & \\
\hline \multirow{2}{*}{$\mathrm{L} 9_{\mathrm{b}}^{\mathrm{a}}$} & $\widehat{0}$ & $18 \cdot 4$ & $67 \cdot 4$ & $18 \cdot 9$ & $78 \cdot 3$ & 0.5 & $10 \cdot 9$ & $12: 5$ & $23: 6$ & 42 & 126 & $3 \cdot 0$ & $11 \cdot 6$ \\
\hline & & $21 \cdot 2$ & $92 \cdot 5$ & $22 \cdot 1$ & $104 \cdot 5$ & $0 \cdot 9$ & $12 \cdot 0$ & $27: 6$ & $10: 11$ & 136 & 545 & $4 \cdot 0$ & $45 \cdot 4$ \\
\hline \multirow{2}{*}{$\mathrm{L} 10_{\mathrm{b}}^{\mathrm{a}}$} & $\widehat{\sigma}$ & $17 \cdot 2$ & $55 \cdot 6$ & $17 \cdot 7$ & $56 \cdot 9$ & 0.5 & $1 \cdot 3$ & $12: 5$ & $4: 8$ & 84 & 242 & $2 \cdot 9$ & $186 \cdot 1$ \\
\hline & & $21 \cdot 4$ & $73 \cdot 9$ & $23 \cdot 1$ & $127 \cdot 7$ & $1 \cdot 7$ & $53 \cdot 8$ & $4: 8$ & $10: 11$ & 98 & 515 & $5 \cdot 3$ & $9 \cdot 6$ \\
\hline \multirow{2}{*}{$\mathrm{L}^{1} 1_{\mathrm{b}}^{\mathrm{a}}$} & $\hat{\sigma}$ & $21 \cdot 8$ & $101 \cdot 2$ & $22 \cdot 7$ & $118 \cdot 8$ & 0.9 & $17 \cdot 6$ & $12: 5$ & $1: 9$ & 112 & 469 & $4 \cdot 2$ & $26 \cdot 6$ \\
\hline & & $22 \cdot 6$ & $120 \cdot 1$ & $23 \cdot 8$ & $160 \cdot 8$ & $1 \cdot 2$ & $40 \cdot 7$ & $29: 9$ & $10: 11$ & 42 & 267 & $6 \cdot 4$ & $6 \cdot 5$ \\
\hline \multirow{2}{*}{$\mathrm{L} 12_{\mathrm{b}}^{\mathrm{a}}$} & $\hat{0}$ & $19 \cdot 3$ & $75 \cdot 1$ & $21 \cdot 3$ & $105 \cdot 6$ & $2 \cdot 0$ & $30 \cdot 5$ & $12: 5$ & $1: 9$ & 112 & 471 & $4 \cdot 2$ & $15 \cdot 4$ \\
\hline & & $20 \cdot 3$ & $86 \cdot 8$ & $20 \cdot 8$ & $102 \cdot 7$ & 0.5 & $15 \cdot 9$ & $29: 9$ & $10: 11$ & 42 & 175 & $4 \cdot 2$ & $11 \cdot 0$ \\
\hline L13 & 우 & $20 \cdot 0$ & $73 \cdot 7$ & $22 \cdot 0$ & $114 \cdot 6$ & $2 \cdot 0$ & $40 \cdot 9$ & $12: 5$ & $10: 11$ & 182 & 819 & $4 \cdot 5$ & $20 \cdot 0$ \\
\hline \multirow{2}{*}{$\mathrm{L}^{1} 4_{\mathrm{b}}^{\mathrm{a}}$} & 우 & $17 \cdot 0$ & $50 \cdot 5$ & $20 \cdot 6$ & $97 \cdot 8$ & $3 \cdot 6$ & $47 \cdot 3$ & $12: 5$ & $1: 9$ & 112 & 546 & $4 \cdot 9$ & $11 \cdot 5$ \\
\hline & & $25 \cdot 1$ & $173 \cdot 2$ & $26 \cdot 1$ & $205 \cdot 3$ & $1 \cdot 0$ & $32 \cdot 1$ & $15: 9$ & $10: 11$ & 56 & 409 & $7 \cdot 3$ & $12 \cdot 7$ \\
\hline L15 & q & $20 \cdot 1$ & $75 \cdot 7$ & $22 \cdot 1$ & $115 \cdot 7$ & $2 \cdot 0$ & $40 \cdot 0$ & $12: 5$ & $10: 11$ & 182 & 896 & $4 \cdot 9$ & $22 \cdot 4$ \\
\hline \multirow{2}{*}{$\mathrm{L} 16_{\mathrm{b}}^{\mathrm{a}}$} & 우 & $19 \cdot 5$ & $79 \cdot 0$ & $20 \cdot 7$ & $102 \cdot 8$ & $1 \cdot 2$ & $23 \cdot 8$ & $12: 5$ & $23: 6$ & 42 & 209 & $5 \cdot 0$ & $8 \cdot 8$ \\
\hline & & $20 \cdot 8$ & $104 \cdot 9$ & $24 \cdot 5$ & $192 \cdot 8$ & $3 \cdot 7$ & $87 \cdot 9$ & $7: 6$ & $10: 11$ & 126 & 827 & $6 \cdot 6$ & $9 \cdot 4$ \\
\hline
\end{tabular}


TABLES 59-62.

Maximum Requirements and Growth of Male Plaice.

TABLE 59: L9 (a and b).

\begin{tabular}{|c|c|c|c|c|c|c|c|c|c|c|c|c|c|}
\hline \multirow{2}{*}{$\begin{array}{l}\text { Date. } \\
\text { (1930) }\end{array}$} & \multicolumn{2}{|c|}{$\begin{array}{l}\text { Size } \\
\text { of } \\
\text { flish. }\end{array}$} & \multirow[t]{2}{*}{ Wt./Lth. ${ }^{3}$} & \multicolumn{2}{|c|}{$\begin{array}{c}\text { Growth } \\
\text { per } \\
\text { period. }\end{array}$} & \multirow{2}{*}{$\begin{array}{c}\text { Total } \\
\text { food } \\
\text { per } \\
\text { period. } \\
\text { (gm.) }\end{array}$} & \multirow[t]{2}{*}{$\begin{array}{c}\begin{array}{c}\text { Gm. of } \\
\text { food } \\
\text { per }\end{array} \\
1.0 \mathrm{gm} . \\
\text { increase } \\
\text { in } \\
\text { weight } \\
\text { of fish. }\end{array}$} & \multirow[t]{2}{*}{$\begin{array}{c}\text { No. of } \\
\text { days } \\
\text { in } \\
\text { period. }\end{array}$} & \multirow{2}{*}{$\begin{array}{c}\text { Average } \\
\text { food } \\
\text { per day } \\
\text { during } \\
\text { each } \\
\text { period. } \\
\text { (gm.) }\end{array}$} & \multirow[t]{2}{*}{$\begin{array}{l}\text { Percent- } \\
\text { age } \\
\text { growth } \\
\text { in wt. }\end{array}$} & \multirow{2}{*}{$\begin{array}{c}\text { Total } \\
\text { food } \\
\text { to date } \\
\text { (gm.) }\end{array}$} & \multicolumn{2}{|c|}{$\begin{array}{l}\text { Cumulative } \\
\text { growth. }\end{array}$} \\
\hline & $\begin{array}{l}\text { Lth. } \\
\text { (em.) }\end{array}$ & $\begin{array}{l}\text { Wt. } \\
\text { (gm.) }\end{array}$ & & $\begin{array}{l}\text { Lth. } \\
\text { (cm.) }\end{array}$ & $\begin{array}{l}\text { Wt. } \\
\text { (gm.) }\end{array}$ & & & & & & & $\begin{array}{l}\text { Lth. } \\
\text { (cm.) }\end{array}$ & $\begin{array}{l}\text { Wt. } \\
\text { (gm.) }\end{array}$ \\
\hline 12 & $18 \cdot 4$ & $67 \cdot 4$ & 0.011 & - & - & - & - & - & - & - & - & - & - \\
\hline 26 & $18 \cdot 5$ & $69 \cdot 0$ & 0.011 & $0 \cdot 1$ & $1 \cdot 6$ & $21 \cdot 1$ & $13 \cdot 2$ & 14 & $1 \cdot 51$ & $2 \cdot 4$ & 21 & $0 \cdot 1$ & $1 \cdot 6$ \\
\hline ne $\quad 9$ & $18 \cdot 8$ & $77 \cdot 6$ & 0.012 & $0 \cdot 3$ & $8 \cdot 6$ & $63 \cdot 2$ & $7 \cdot 3$ & 14 & $4 \cdot 51$ & $12 \cdot 5$ & 84 & 0.4 & $10 \cdot 2$ \\
\hline 23 & 18.9 & $78 \cdot 3$ & 0.012 & $0 \cdot 1$ & 0.7 & 420 & $60 \cdot 0$ & 14 & 3.00 & 0.9 & 126 & 0.5 & $10 \cdot 9$ \\
\hline & & & & & & & & & & & & & \\
\hline ne 27 & $21 \cdot 2$ & $92 \cdot 5$ & 0.010 & - & - & - & - & - & - & - & - & - & - \\
\hline 7 & $21 \cdot 3$ & $92 \cdot 6$ & 0.01 & $0 \cdot 1$ & $0 \cdot 1$ & $48 \cdot 0$ & $480 \cdot 0$ & 10 & $4 \cdot 80$ & $0 \cdot 1$ & 48 & $0 \cdot 1$ & $0 \cdot 1$ \\
\hline 21 & $21 \cdot 5$ & $94 \cdot 8$ & 0.010 & $0 \cdot 2$ & $2 \cdot 2$ & $63 \cdot 1$ & $28 \cdot 7$ & 14 & $4 \cdot 51$ & $2 \cdot 4$ & 111 & $0 \cdot 3$ & $2 \cdot 3$ \\
\hline . 4 & $21 \cdot 2$ & $96 \cdot 6$ & 0.010 & $-0 \cdot 3$ & 1.8 & $56 \cdot 9$ & $31 \cdot 6$ & 14 & $4 \cdot 06$ & $1 \cdot 9$ & 168 & nil & $4 \cdot 1$ \\
\hline 18 & $21 \cdot 7$ & $101 \cdot 2$ & 0.010 & 0.5 & $4 \cdot 6$ & $60 \cdot 9$ & $13 \cdot 2$ & 14 & $4 \cdot 35$ & $4 \cdot 8$ & 229 & 0.5 & $8 \cdot 7$ \\
\hline pt. 1 & $21 \cdot 8$ & $101 \cdot 1$ & $0 \cdot 010$ & $0 \cdot 1$ & $-0 \cdot 1$ & $61 \cdot 6$ & - & 14 & $4 \cdot 40$ & - & 290 & 0.6 & $8 \cdot 6$ \\
\hline 15 & $21 \cdot 9$ & $95 \cdot 9$ & 0.009 & $0 \cdot 1$ & $-5 \cdot 2$ & $38 \cdot 2$ & - & 14 & $2 \cdot 73$ & - & 329 & 0.7 & $3 \cdot 4$ \\
\hline 29 & $22 \cdot 0$ & $100 \cdot 5$ & 0.01 & $0 \cdot 1$ & $4 \cdot 6$ & $50 \cdot 7$ & $11 \cdot 0$ & 14 & $3 \cdot 62$ & $4 \cdot 8$ & 37 & 0.8 & $8 \cdot 0$ \\
\hline 13 & $22 \cdot 0$ & $103 \cdot 8$ & 0.0 . & nil & $3 \cdot 3$ & $66 \cdot 4$ & $20 \cdot 1$ & 14 & $4 \cdot 74$ & $3 \cdot 3$ & 446 & 0.8 & $11 \cdot 3$ \\
\hline 27 & $22 \cdot 1$ & $108 \cdot 1$ & 0.01 & $0 \cdot 1$ & $4 \cdot 3$ & $59 \cdot 1$ & $13 \cdot 7$ & 14 & $4 \cdot 22$ & $4 \cdot 1$ & 505 & 0.9 & $15 \cdot 6$ \\
\hline 10 & $22 \cdot 1$ & 104. & $0 \cdot 0$ & nil & $-3 \cdot 6$ & $40 \cdot 5$ & - & 14 & $2 \cdot 89$ & - & 545 & 0.9 & $12 \cdot 0$ \\
\hline 24 & $22 \cdot 1$ & $104 \cdot 6$ & 0.010 & nil & $0 \cdot 1$ & $20 \cdot 1$ & $201 \cdot 0$ & 14 & $1 \cdot 44$ & $0 \cdot 1$ & 565 & 0.9 & $12 \cdot 1$ \\
\hline
\end{tabular}

TABle 60: L10 (a and b).

(a)

\begin{tabular}{|c|c|c|c|c|c|c|c|c|c|c|c|c|c|c|}
\hline May & 12 & $17 \cdot 2$ & $55 \cdot 6$ & 0.011 & - & - & - & - & - & - & - & - & - & - \\
\hline & 26 & $17 \cdot 2$ & $53 \cdot 8$ & 0.011 & nil & $-1 \cdot 8$ & $28 \cdot 8$ & - & 14 & $2 \cdot 06$ & - & 29 & nil & $-1 \cdot 8$ \\
\hline June & 9 & $17 \cdot 4$ & $57 \cdot 7$ & 0.011 & 0.2 & $3 \cdot 9$ & $65 \cdot 5$ & $16 \cdot 8$ & 14 & $4 \cdot 68$ & $7 \cdot 2$ & 94 & $0 \cdot 2$ & $2 \cdot 1$ \\
\hline & 23 & $17 \cdot 7$ & $60 \cdot 0$ & 0.011 & $0 \cdot 3$ & $2 \cdot 3$ & $45 \cdot 5$ & $19 \cdot 8$ & 14 & $3 \cdot 25$ & $4 \cdot 0$ & 140 & 0.5 & $4 \cdot 4$ \\
\hline July & 7 & $17 \cdot 7$ & $60 \cdot 7$ & 0.011 & nil & $0 \cdot 7$ & $41 \cdot 9$ & $59 \cdot 9$ & 14 & $2 \cdot 99$ & $1 \cdot 2$ & 182 & 0.5 & $5 \cdot 1$ \\
\hline & 21 & $17 \cdot 7$ & $59 \cdot 9$ & 0.011 & nil & -0.8 & 38.4 & - & 14 & $2 \cdot 74$ & - & 220 & 0.5 & $4 \cdot 3$ \\
\hline lug. & 4 & $17 \cdot 7$ & $56 \cdot 9$ & 0.010 & nil & $-3 \cdot 0$ & $20 \cdot 8$ & - & 14 & $1 \cdot 49$ & - & 241 & 0.5 & $1 \cdot 3$ \\
\hline (b) & & & & & & & & & & & & & & \\
\hline Aug. & 4 & $21 \cdot 4$ & $73 \cdot 9$ & $0 \cdot 008$ & - & - & - & - & - & - & - & - & - & - \\
\hline & 18 & $21 \cdot 6$ & $84 \cdot 3$ & 0.008 & 0.2 & $10 \cdot 4$ & $59 \cdot 4$ & $5 \cdot 7$ & 14 & $4 \cdot 24$ & $14 \cdot 1$ & 59 & 0.2 & $10 \cdot 4$ \\
\hline Sept. & 1 & $21 \cdot 8$ & $89 \cdot 8$ & $0 \cdot 009$ & 0.2 & $5 \cdot 5$ & 68.8 & 12.5 & 14 & $4 \cdot 91$ & $6 \cdot 5$ & 128 & 0.4 & $15 \cdot 9$ \\
\hline , & 15 & $22 \cdot 0$ & 97.5 & 0.009 & $0 \cdot 2$ & $7 \cdot 7$ & $66 \cdot 9$ & $8 \cdot 7$ & 14 & $4 \cdot 78$ & $8 \cdot 6$ & 195 & $0 \cdot 6$ & $23 \cdot 6$ \\
\hline & 29 & $22 \cdot 3$ & $107 \cdot 7$ & 0.010 & $0 \cdot 3$ & $10 \cdot 2$ & $81 \cdot 8$ & 8.0 & 14 & $5 \cdot 84$ & $10 \cdot 5$ & 277 & 0.9 & $33 \cdot 8$ \\
\hline Oct. & 13 & $22 \cdot 7$ & $119 \cdot 1$ & $0 \cdot 010$ & 0.4 & $11 \cdot 4$ & $96 \cdot 8$ & 8.5 & 14 & $6 \cdot 91$ & $10 \cdot 6$ & 374 & $1 \cdot 3$ & $45 \cdot 2$ \\
\hline & 27 & $22 \cdot 9$ & $123 \cdot 0$ & $0 \cdot 010$ & $0 \cdot 2$ & 3.9 & $83 \cdot 1$ & $21 \cdot 3$ & 14 & $5 \cdot 94$ & $3 \cdot 3$ & 457 & $1 \cdot 5$ & $49 \cdot 1$ \\
\hline & 10 & $23 \cdot 1$ & $127 \cdot 7$ & 0.010 & $0 \cdot 2$ & $4 \cdot 7$ & $57 \cdot 9$ & $12 \cdot 3$ & 14 & $4 \cdot 14$ & $3 \cdot 8$ & 515 & $1 \cdot 7$ & $53 \cdot 8$ \\
\hline & 24 & $23 \cdot 2$ & $129 \cdot 6$ & $0 \cdot 010$ & $0 \cdot 1$ & $1 \cdot 9$ & $28 \cdot 6$ & $15 \cdot 1$ & 14 & $2 \cdot 04$ & $1 \cdot 5$ & 543 & $1 \cdot 8$ & $55 \cdot 7$ \\
\hline
\end{tabular}


TABLe 61: L11 (a and b).

\begin{tabular}{|c|c|c|c|c|c|c|c|c|c|c|c|c|c|}
\hline \multirow[b]{2}{*}{$\begin{array}{l}\text { Date. } \\
\text { (1930) }\end{array}$} & \multicolumn{2}{|c|}{$\begin{array}{l}\text { Size } \\
\text { of } \\
\text { fish. }\end{array}$} & \multirow[t]{2}{*}{ Wt.//Lth. ${ }^{3}$} & \multicolumn{2}{|c|}{$\begin{array}{l}\text { Growth } \\
\text { per } \\
\text { period. }\end{array}$} & \multirow{2}{*}{$\begin{array}{l}\text { Total } \\
\text { food } \\
\text { per } \\
\text { period. } \\
\text { (gm.) }\end{array}$} & \multirow[t]{2}{*}{$\begin{array}{l}\text { Gm. of } \\
\text { food } \\
\text { per } \\
1.0 \mathrm{gm} . \\
\text { increase } \\
\text { in } \\
\text { weight } \\
\text { of fish. }\end{array}$} & \multirow{2}{*}{$\begin{array}{c}\text { No. of } \\
\text { days } \\
\text { in } \\
\text { period. }\end{array}$} & \multirow{2}{*}{$\begin{array}{c}\text { Average } \\
\text { food } \\
\text { per day } \\
\text { during } \\
\text { each } \\
\text { period. } \\
\text { (gm.) }\end{array}$} & \multirow{2}{*}{$\begin{array}{l}\text { Percent- } \\
\text { age } \\
\text { growth } \\
\text { in wt. }\end{array}$} & \multirow{2}{*}{$\begin{array}{l}\text { Total } \\
\text { food } \\
\text { to date } \\
\text { (gm.) }\end{array}$} & \multicolumn{2}{|c|}{$\begin{array}{c}\text { Cumulative } \\
\text { growth. }\end{array}$} \\
\hline & $\begin{array}{l}\text { Lth. } \\
\text { (cm.) }\end{array}$ & $\begin{array}{l}\text { Wt. } \\
\text { (gm.) }\end{array}$ & & $\begin{array}{l}\text { Lth. } \\
(\mathrm{cm} .)\end{array}$ & $\begin{array}{l}\text { Wt. } \\
\text { (gm.) }\end{array}$ & & & & & & & $\begin{array}{l}\text { Lth. } \\
\text { (cm.) }\end{array}$ & $\begin{array}{l}\text { Wt. } \\
\text { (gm.) }\end{array}$ \\
\hline May 12 & $21 \cdot 8$ & $101 \cdot 2$ & $0 \cdot 010$ & - & - & - & - & - & - & - & - & - & - \\
\hline,,$\quad 26$ & $21 \cdot 9$ & $100 \cdot 2$ & $0 \cdot 010$ & $0 \cdot 1$ & $-1 \cdot 0$ & $40 \cdot 2$ & - & 14 & $2 \cdot 87$ & - & 40 & $0 \cdot 1$ & $-1 \cdot 0$ \\
\hline June 9 & 21.9 & $96 \cdot 6$ & 0.009 & nil & $-3 \cdot 6$ & $51 \cdot 6$ & - & 14 & $3 \cdot 69$ & - & 92 & $0 \cdot 1$ & $-4 \cdot 6$ \\
\hline,$\quad 23$ & $22 \cdot 0$ & $102 \cdot 3$ & 0.010 & $0 \cdot 1$ & $5 \cdot 7$ & $59 \cdot 1$ & $10 \cdot 4$ & 14 & $4 \cdot 22$ & $5 \cdot 9$ & 151 & $0 \cdot 2$ & $1 \cdot 1$ \\
\hline July 7 & $22 \cdot 1$ & $105 \cdot 0$ & 0.010 & $0 \cdot 1$ & $2 \cdot 7$ & $60 \cdot 8$ & $22 \cdot 5$ & 14 & $4 \cdot 34$ & $2 \cdot 6$ & 212 & $0 \cdot 3$ & $3 \cdot 8$ \\
\hline,$\quad 21$ & $22 \cdot 3$ & $110 \cdot 3$ & 0.010 & $0 \cdot 2$ & $5 \cdot 3$ & $62 \cdot 5$ & $11 \cdot 8$ & 14 & $4 \cdot 46$ & $5 \cdot 0$ & 274 & 0.5 & $9 \cdot 1$ \\
\hline Aug. 4 & $22 \cdot 4$ & $114 \cdot 6$ & 0.010 & $0 \cdot 1$ & $4 \cdot 3$ & $62 \cdot 6$ & $12 \cdot 2$ & 14 & $4 \cdot 47$ & $3 \cdot 9$ & 337 & $0 \cdot 6$ & $13 \cdot 4$ \\
\hline,$\quad 18$ & $22 \cdot 5$ & $120 \cdot 0$ & 0.011 & $0 \cdot 1$ & $5 \cdot 4$ & $68 \cdot 2$ & $12 \cdot 6$ & 14 & $4 \cdot 87$ & $4 \cdot 7$ & 405 & $0 \cdot 7$ & $18 \cdot 8$ \\
\hline Sept. 1 & $22 \cdot 7$ & $118 \cdot 8$ & 0.010 & $0 \cdot 2$ & $-1 \cdot 2$ & $61 \cdot 9$ & - & 14 & $4 \cdot 42$ & - & 467 & 0.9 & $17 \cdot 6$ \\
\hline (b) & & & & & & & & & & & & & \\
\hline Sept. 29 & $22 \cdot 6$ & $120 \cdot 1$ & 0.010 & - & - & - & - & - & - & - & - & - & - \\
\hline Oct. 13 & $22 \cdot 9$ & $136 \cdot 9$ & 0.010 & $0 \cdot 3$ & $16 \cdot 8$ & $75 \cdot 0$ & $4 \cdot 5$ & 14 & $5 \cdot 36$ & $13 \cdot 9$ & 75 & $0 \cdot 3$ & $16 \cdot 8$ \\
\hline,,$\quad 27$ & $23 \cdot 5$ & 158.5 & $0 \cdot 012$ & $0 \cdot 6$ & $21 \cdot 6$ & $103 \cdot 3$ & $4 \cdot 8$ & 14 & $7 \cdot 36$ & $15 \cdot 8$ & 178 & 0.9 & $38 \cdot 4$ \\
\hline Nov. 10 & $23 \cdot 8$ & $160 \cdot 8$ & 0.012 & $0 \cdot 3$ & $2 \cdot 3$ & $88 \cdot 5$ & $38 \cdot 5$ & 14 & $6 \cdot 32$ & $1 \cdot 5$ & 267 & $1 \cdot 2$ & $40 \cdot 7$ \\
\hline,$\quad 24$ & $23 \cdot 9$ & $166 \cdot 2$ & 0.012 & $0 \cdot 1$ & $5 \cdot 4$ & $45 \cdot 1$ & $8 \cdot 4$ & 14 & $3 \cdot 23$ & $3 \cdot 4$ & 312 & $1 \cdot 3$ & $46 \cdot 1$ \\
\hline
\end{tabular}

TABle 62: L12 (a and b).

(a)

May
June
July
Aug.
Sept.
(b)
Sept.

Sept. 29

Oct. 13

, 27

Nov. 10
$19 \cdot 3 \quad 75 \cdot 1$

$19 \cdot 6 \quad 82 \cdot 3$

$20 \cdot 0 \quad 86 \cdot 9$

$20 \cdot 2 \quad 89 \cdot 3$

$20 \cdot 4 \quad 90 \cdot 5$

$20 \cdot 5 \quad 95 \cdot 1$

$20 \cdot 8 \quad 99 \cdot 9$

$21 \cdot 1 \quad 104 \cdot 3$

$21 \cdot 3 \quad 105 \cdot 6$

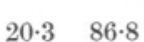

$20 \cdot 4 \quad 92 \cdot$

$20 \cdot 7 \quad 99 \cdot 0$

$20 \cdot 8 \quad 102 \cdot 7$

$20.9 \quad 105 \cdot 4$

\section{$0 \cdot 010$}

$0 \cdot 011$

$0 \cdot 011$

$0 \cdot 011$

$0 \cdot 011$

$0 \cdot 011$

$0 \cdot 011$

$0 \cdot 011$

$0 \cdot 011$ $\overline{0 \cdot 3} \quad \overline{7 \cdot 2}$

$0 \cdot 4 \quad 4 \cdot 6$

$0 \cdot 2 \quad 2 \cdot 4$

$0 \cdot 2 \quad 1 \cdot 2$

$0 \cdot 1 \quad 4 \cdot 6$

$0 \cdot 3 \quad 4 \cdot 8$

$0 \cdot 3 \quad 4 \cdot 4$

$0 \cdot 2 \quad 1 \cdot 3$ $\overline{51 \cdot 6} \quad \overline{7 \cdot 2} \quad \overline{14}$

$64 \cdot 7 \quad 14 \cdot 1 \quad 14$

$\begin{array}{lll}61 \cdot 8 & 25 \cdot 7 & 14\end{array}$

$56 \cdot 7 \quad 47 \cdot 2 \quad 14$

$55.0 \quad 12 \cdot 0 \quad 14$

$\begin{array}{lll}58.9 & 12.3 & 14\end{array}$

$\begin{array}{lll}63.3 & 14.4 & 14\end{array}$

$59 \cdot 3$

$3 \cdot 69$
$4 \cdot 62$
$4 \cdot 41$
$4 \cdot 05$
$3 \cdot 93$
$4 \cdot 21$
$4 \cdot 52$
$4 \cdot 24$

$\overline{9 \cdot 6}$

$5 \cdot 6-116$

$2 \cdot 8 \quad 178$

$1 \cdot 3 \quad 235$

$5 \cdot 1 \quad 290$

$5 \cdot 0 \quad 349$

$4 \cdot 4 \quad 412$

$1 \cdot 2 \quad 471$

$\overline{0.3} \quad \overline{7 \cdot 2}$

$\begin{array}{ll}0.7 & 11.8\end{array}$

$0.9 \quad 14 \cdot 2$

$1 \cdot 1 \quad 15 \cdot 4$

$1 \cdot 2 . \quad 20 \cdot 0$

$1.5 \quad 24 \cdot 8$

$1 \cdot 8 \quad 29 \cdot 2$

$2 \cdot 0 \quad 30 \cdot 5$

$\begin{array}{llllrllllll}0 \cdot 010 & - & - & - & - & - & - & - & - & - & - \\ 0 \cdot 011 & 0 \cdot 1 & 5 \cdot 3 & 61 \cdot 0 & 11 \cdot 5 & 14 & 4 \cdot 36 & 6 \cdot 1 & 61 & 0 \cdot 1 & 5 \cdot 3 \\ 0 \cdot 011 & 0 \cdot 3 & 6 \cdot 9 & 61 \cdot 5 & 8 \cdot 9 & 14 & 4 \cdot 39 & 7 \cdot 5 & 122 & 0 \cdot 4 & 12 \cdot 2 \\ 0 \cdot 011 & 0 \cdot 1 & 3 \cdot 7 & 52 \cdot 3 & 14 \cdot 1 & 14 & 3 \cdot 74 & 3 \cdot 7 & 175 & 0 \cdot 5 & 15 \cdot 9 \\ 0 \cdot 012 & 0 \cdot 1 & 2 \cdot 7 & 36 \cdot 5 & 13 \cdot 5 & 14 & 2 \cdot 61 & 2 \cdot 6 & 211 & 0 \cdot 6 & 18 \cdot 6\end{array}$


TABLES 63-66.

Maximum Requirements and Growth of Female Platce.

TABLe 63: L13.

\begin{tabular}{|c|c|c|c|c|c|c|c|c|c|c|c|c|c|}
\hline \multirow[b]{2}{*}{$\begin{array}{l}\text { Date. } \\
\text { (1930) }\end{array}$} & $\begin{array}{r}\mathrm{Si} \\
\mathrm{o} \\
\text { fis }\end{array}$ & & \multirow[t]{2}{*}{$\begin{array}{l}\text { Wt./ } \\
\text { /Lth. }\end{array}$} & \multicolumn{2}{|c|}{$\begin{array}{l}\text { Growth } \\
\text { per } \\
\text { period. }\end{array}$} & \multirow{2}{*}{$\begin{array}{l}\text { Total } \\
\text { food } \\
\text { per } \\
\text { period. } \\
\text { (gm.) }\end{array}$} & \multirow[t]{2}{*}{$\begin{array}{c}\text { Gm. of } \\
\text { food } \\
\text { per } \\
1 \cdot 0 \mathrm{gm} \text {. } \\
\text { increase } \\
\text { in } \\
\text { weight } \\
\text { of fish. }\end{array}$} & \multirow[t]{2}{*}{$\begin{array}{l}\text { No. of } \\
\text { days } \\
\text { in } \\
\text { period. }\end{array}$} & \multirow{2}{*}{$\begin{array}{c}\text { Average } \\
\text { food } \\
\text { per day } \\
\text { during } \\
\text { each } \\
\text { period. } \\
\text { (gm.) }\end{array}$} & \multirow[t]{2}{*}{$\begin{array}{l}\text { Percent- } \\
\text { age } \\
\text { growth } \\
\text { in wt. }\end{array}$} & \multirow{2}{*}{$\begin{array}{l}\text { Total } \\
\text { food } \\
\text { to date } \\
\text { (gm.) }\end{array}$} & \multicolumn{2}{|c|}{$\begin{array}{l}\text { Cumulative } \\
\text { growth. }\end{array}$} \\
\hline & $\begin{array}{l}\text { Lth. } \\
\text { (cm.) }\end{array}$ & $\begin{array}{l}\text { Wt. } \\
\text { (gm.) }\end{array}$ & & $\begin{array}{l}\text { Lth. } \\
\text { (em.) }\end{array}$ & $\begin{array}{l}\text { Wt. } \\
\text { (gm.) }\end{array}$ & & & & & & & $\begin{array}{l}\text { Lth. } \\
\text { (em.) }\end{array}$ & $\begin{array}{c}\text { Wt. } \\
\text { (gm.) }\end{array}$ \\
\hline May 12 & $20 \cdot 0$ & $73 \cdot 7$ & 0.009 & - & - & - & - & - & - & - & - & - & - \\
\hline,$\quad 26$ & $20 \cdot 3$ & $85 \cdot 7$ & 0.010 & $0 \cdot 3$ & $12 \cdot 0$ & $53 \cdot 9$ & $4 \cdot 5$ & 14 & $3 \cdot 85$ & $16 \cdot 3$ & 54 & $0 \cdot 3$ & $12 \cdot 0$ \\
\hline June 9 & $20 \cdot 6$ & $88 \cdot 2$ & 0.010 & $0 \cdot 3$ & $2 \cdot 5$ & $74 \cdot 9$ & $30 \cdot 0$ & 14 & $5 \cdot 35$ & $2 \cdot 9$ & 129 & $0 \cdot 6$ & 14.5 \\
\hline,,$\quad 23$ & $20 \cdot 7$ & $94 \cdot 6$ & $0 \cdot 011$ & $0 \cdot 1$ & $6 \cdot 4$ & $71 \cdot 7$ & $11 \cdot 2$ & 14 & $5 \cdot 12$ & $7 \cdot 3$ & 200 & $0 \cdot 7$ & $20 \cdot 9$ \\
\hline July 7 & $20 \cdot 8$ & $100 \cdot 2$ & 0.011 & $0 \cdot 1$ & $5 \cdot 6$ & $69 \cdot 3$ & $1,2 \cdot 4$ & 14 & 4.95 & $5 \cdot 9$ & 270 & $0 \cdot 8$ & $26 \cdot 5$ \\
\hline,$\quad 21$ & $21 \cdot 0$ & $103 \cdot 7$ & 0.011 & $0 \cdot 2$ & $6 \cdot 5$ & $62 \cdot 3$ & $9 \cdot 6$ & 14 & $4 \cdot 45$ & $6 \cdot 5$ & 332 & $1 \cdot 0$ & $33 \cdot 0$ \\
\hline Aug. 4 & $21 \cdot 3$ & $109 \cdot 1$ & 0.011 & $0 \cdot 3$ & $2 \cdot 4$ & 66.0 & $27 \cdot 5$ & 14 & $4 \cdot 71$ & $1 \cdot 3$ & 398 & $1 \cdot 3$ & $35 \cdot 4$ \\
\hline,$\quad 18$ & $21 \cdot 3$ & $109 \cdot 3$ & $0 \cdot 011$ & nil & $0 \cdot 2$ & $66 \cdot 1$ & $330 \cdot 0$ & 14 & $4 \cdot 72$ & $0 \cdot 2$ & 464 & $1 \cdot 3$ & $35 \cdot 6$ \\
\hline Sept. 1 & $21 \cdot 3$ & $106 \cdot 4$ & 0.011 & nil & $-2 \cdot 9$ & $63 \cdot 5$ & - & 14 & $4 \cdot 54$ & - & 528 & $1 \cdot 3$ & $32 \cdot 7$ \\
\hline,,$\quad 15$ & $21 \cdot 4$ & $107 \cdot 0$ & 0.011 & $0 \cdot 1$ & $0 \cdot 6$ & $48 \cdot 4$ & $80 \cdot 6$ & 14 & $3 \cdot 46$ & $0 \cdot 6$ & 576 & $1 \cdot 4$ & $33 \cdot 3$ \\
\hline ,, 29 & $21 \cdot 5$ & $108 \cdot 9$ & 0.011 & 0.1 & 1.9 & $46 \cdot 0$ & $24 \cdot 2$ & 14 & $3 \cdot 29$ & $1 \cdot 8$ & 622 & 1.5 & $35 \cdot 2$ \\
\hline Oct. 13 & $21 \cdot 7$ & $120 \cdot 0$ & 0.012 & $0 \cdot 2$ & $11 \cdot 1$ & $77 \cdot 9$ & $7 \cdot 0$ & 14 & $5 \cdot 56$ & $10 \cdot 2$ & 700 & $1 \cdot 7$ & $46 \cdot 3$ \\
\hline , $\quad 27$ & $22 \cdot 0$ & $123 \cdot 1$ & 0.012 & $0 \cdot 3$ & $3 \cdot 1$ & $75 \cdot 8$ & $24 \cdot 5$ & 14 & $5 \cdot 41$ & $2 \cdot 6$ & 776 & $2 \cdot 0$ & $49 \cdot 4$ \\
\hline Nov. 10 & $22 \cdot 0$ & $114 \cdot 6$ & $0 \cdot 011$ & nil & $-8 \cdot 5$ & $45 \cdot 5$ & - & 14 & $3 \cdot 25$ & - & 821 & $2 \cdot 0$ & $40 \cdot 9$ \\
\hline,,$\quad 24$ & $22 \cdot 0$ & $121 \cdot 1$ & 0.012 & nil & $6 \cdot 5$ & $22 \cdot 4$ & $3 \cdot 4$ & 14 & $1 \cdot 60$ & $5 \cdot 7$ & 844 & $2 \cdot 0$ & $47 \cdot 4$ \\
\hline
\end{tabular}

(a)

$\begin{array}{lrrr}\text { May } & 12 & 17 \cdot 0 & 50 \cdot 5 \\ \text { June } & 26 & 17 \cdot 8 & 66 \cdot 8 \\ \text { Jun } & 18 \cdot 7 & 78 \cdot 0 \\ \text { July } & 23 & 19 \cdot 1 & 83 \cdot 5 \\ \text { ", } & 21 & 19 \cdot 3 & 86 \cdot 8 \\ \text { Aug. } & 4 & 20 \cdot 6 & 93 \cdot 1 \\ \text {, } & 18 & 20 \cdot 3 & 97 \cdot 7 \\ \text { Sept. } 1 & 20 \cdot 6 & 97 \cdot 8\end{array}$

(b)

Sept. $15 \quad 25 \cdot 1 \quad 173 \cdot 2$

$\begin{array}{llll}\text {,. } & 29 & 25.4 & 182 \cdot 2\end{array}$

$\begin{array}{lll}\text { Oct. } 13 \quad 25 \cdot 9 & 200 \cdot 4\end{array}$

$\begin{array}{llll}, \quad 27 & 26 \cdot 1 & 211 \cdot 3\end{array}$

Nov. $10 \quad 26 \cdot 1 \quad 205 \cdot 3$

, $24 \quad 26 \cdot 1 \quad 204 \cdot 4$

$\begin{array}{llr}0.010 & & - \\ 0.012 & 0.8 & 16.3 \\ 0.012 & 0.9 & 11.2 \\ 0.012 & 0.4 & 5.5 \\ 0.012 & 0.2 & 3 \cdot 3 \\ 0.012 & 0.3 & 6 \cdot 6 \\ 0.012 & 0.5 & 4 \cdot 3 \\ 0.012 & 0.2 & -0.6 \\ 0.011 & 0.3 & 0.7\end{array}$

TABLE 64: L14 ( $a$ and $b)$.

$\begin{array}{rrrrrrrrrrr}0 \cdot 011 & - & - & - & - & - & - & - & - & - & - \\ 0 \cdot 011 & 0 \cdot 3 & 9 \cdot 0 & 72 \cdot 9 & 8 \cdot 1 & 14 & 5 \cdot 21 & 5 \cdot 2 & 73 & 0 \cdot 3 & 9 \cdot 0 \\ 0 \cdot 012 & 0 \cdot 5 & 18 \cdot 2 & 115 \cdot 0 & 6 \cdot 3 & 14 & 8 \cdot 21 & 10 \cdot 0 & 188 & 0 \cdot 8 & 27 \cdot 2 \\ 0 \cdot 012 & 0 \cdot 2 & 10 \cdot 9 & 119 \cdot 4 & 11 \cdot 0 & 14 & 8 \cdot 53 & 5 \cdot 4 & 307 & 1 \cdot 0 & 38 \cdot 1 \\ 0 \cdot 012 & \text { nil }-6 \cdot 0 & 101 \cdot 8 & - & 14 & 7 \cdot 27 & - & 409 & 1 \cdot 0 & 32 \cdot 1 \\ 0.011 & \text { nil }-0.9 & 26.9 & - & 14 & 1 \cdot 92 & - & 436 & 1 \cdot 0 & 31 \cdot 2\end{array}$


Table 65: L15.

\begin{tabular}{|c|c|c|c|c|c|c|c|c|c|c|c|c|c|}
\hline \multirow[b]{2}{*}{$\begin{array}{l}\text { Date. } \\
(\mathbf{1 9 3 0 )}\end{array}$} & \multicolumn{2}{|c|}{$\begin{array}{l}\text { Size } \\
\text { of } \\
\text { fish. }\end{array}$} & \multirow[t]{2}{*}{ Wt.//hth. ${ }^{3}$} & \multicolumn{2}{|c|}{$\begin{array}{l}\text { Growth } \\
\text { per } \\
\text { period. }\end{array}$} & \multirow{2}{*}{$\begin{array}{l}\text { Total } \\
\text { food } \\
\text { per } \\
\text { period. } \\
\text { (gm.) }\end{array}$} & \multirow[t]{2}{*}{$\begin{array}{l}\text { per } \\
1.0 \mathrm{gm} . \\
\text { increase } \\
\text { in } \\
\text { weight } \\
\text { of flish. }\end{array}$} & \multirow[t]{2}{*}{$\begin{array}{c}\text { No. of } \\
\text { days } \\
\text { in } \\
\text { period. }\end{array}$} & \multirow{2}{*}{$\begin{array}{c}\text { Average } \\
\text { food } \\
\text { per day } \\
\text { during } \\
\text { each } \\
\text { period. } \\
\text { (gm.) }\end{array}$} & \multirow{2}{*}{$\begin{array}{l}\text { Percent- } \\
\text { age } \\
\text { growth } \\
\text { in wt. }\end{array}$} & \multirow{2}{*}{$\begin{array}{l}\text { Total } \\
\text { food } \\
\text { to date } \\
\text { (gm.) }\end{array}$} & \multicolumn{2}{|c|}{$\begin{array}{l}\text { Cumulative } \\
\text { growth. }\end{array}$} \\
\hline & $\begin{array}{l}\text { Lth. } \\
\text { (em.) }\end{array}$ & $\begin{array}{c}\text { Wt. } \\
\text { (gm.) }\end{array}$ & & $\begin{array}{l}\text { Lth. } \\
\text { (cm.) }\end{array}$ & $\begin{array}{l}\text { Wt. } \\
\text { (gm.) }\end{array}$ & & & & & & & $\begin{array}{l}\text { Lth. } \\
\text { (cm.) }\end{array}$ & $\begin{array}{l}\text { Wt. } \\
\text { (gm.) }\end{array}$ \\
\hline May 12 & $20 \cdot 1$ & $75 \cdot 7$ & 0.009 & - & - & - & - & - & - & - & - & - & - \\
\hline & $20 \cdot 2$ & $85 \cdot 2$ & 0.010 & $0 \cdot 1$ & $9 \cdot 5$ & $61 \cdot 0$ & $6 \cdot 4$ & 14 & $4 \cdot 36$ & $12 \cdot 5$ & 61 & $0 \cdot 1$ & $9 \cdot 5$ \\
\hline June 9 & $20 \cdot 8$ & $96 \cdot 7$ & 0.011 & 0.6 & $11 \cdot 5$ & $94 \cdot 2$ & $8 \cdot 2$ & 14 & $6 \cdot 73$ & $13 \cdot 5$ & 155 & $0 \cdot 7$ & $21 \cdot 0$ \\
\hline ,, 23 & $21 \cdot 0$ & $102 \cdot 1$ & 0.011 & $0 \cdot 2$ & $5 \cdot 4$ & $86 \cdot 4$ & 16.0 & 14 & $6 \cdot 17$ & $5 \cdot 6$ & 242 & $0 \cdot 9$ & $26 \cdot 4$ \\
\hline July 7 & $21 \cdot 1$ & $106 \cdot 5$ & 0.011 & $0 \cdot 1$ & $4 \cdot 4$ & $68 \cdot 8$ & $15 \cdot 6$ & 14 & $4 \cdot 91$ & $4 \cdot 3$ & 310 & $1 \cdot 0$ & $30 \cdot 8$ \\
\hline,$\quad 21$ & $21 \cdot 2$ & $108 \cdot 6$ & 0.011 & $0 \cdot 1$ & $2 \cdot 1$ & $70 \cdot 6$ & $33 \cdot 6$ & 14 & $5 \cdot 04$ & $1 \cdot 0$ & 381 & $1 \cdot 1$ & $32 \cdot 9$ \\
\hline Aug. 4 & $21 \cdot 5$ & $111 \cdot 6$ & $0 \cdot 011$ & $0 \cdot 3$ & $3 \cdot 0$ & $71 \cdot 0$ & $23 \cdot 7$ & 14 & $5 \cdot 07$ & $2 \cdot 8$ & 452 & 1.4 & $35 \cdot 9$ \\
\hline ," 18 & $21 \cdot 6$ & $114 \cdot 1$ & $0 \cdot 011$ & $0 \cdot 1$ & $2 \cdot 5$ & $72 \cdot 6$ & $29 \cdot 0$ & 14 & $5 \cdot 19$ & $2 \cdot 2$ & 525 & $1 \cdot 5$ & $38 \cdot 4$ \\
\hline Sept. 1 & $21 \cdot 6$ & $110 \cdot 4$ & 0.011 & nil & $-3 \cdot 7$ & $65 \cdot 2$ & - & 14 & $4 \cdot 66$ & - & 590 & 1.5 & $34 \cdot 7$ \\
\hline & $21 \cdot 7$ & $111 \cdot 3$ & $0 \cdot 011$ & $0 \cdot 1$ & 0.9 & $60 \cdot 4$ & $67 \cdot 1$ & 14 & $4 \cdot 31$ & $0 \cdot 8$ & 650 & $1 \cdot 6$ & $35 \cdot 6$ \\
\hline , 29 & 21.9 & $115 \cdot 3$ & 0.011 & $0 \cdot 2$ & $4 \cdot 0$ & $66 \cdot 9$ & $16 \cdot 7$ & 14 & $4 \cdot 78$ & $3 \cdot 6$ & 717 & $1 \cdot 8$ & $39 \cdot 6$ \\
\hline Oct. 13 & $22 \cdot 1$ & $118 \cdot 7$ & 0.011 & $0 \cdot 2$ & $3 \cdot 4$ & $77 \cdot 3$ & $22 \cdot 7$ & 14 & $5 \cdot 52$ & $3 \cdot 0$ & 794 & $2 \cdot 0$ & $43 \cdot 0$ \\
\hline $\begin{array}{ll}27 & 27 \\
\text { Nov. } & 10\end{array}$ & $22 \cdot 1$ & $120 \cdot 4$ & 0.011 & nil & $1 \cdot 7$ & $57 \cdot 4$ & $33 \cdot 8$ & 14 & $4 \cdot 10$ & $1 \cdot 4$ & 852 & $2 \cdot 0$ & $44 \cdot 7$ \\
\hline Nov. 10 & $22 \cdot 1$ & $115 \cdot 7$ & 0.011 & nil - & $-4 \cdot 7$ & $44 \cdot 0$ & - & 14 & $3 \cdot 14$ & - & 896 & $2 \cdot 0$ & $40 \cdot 0$ \\
\hline , 24 & $22 \cdot 1$ & $114 \cdot 4$ & $0 \cdot 011$ & nil & $-1 \cdot 3$ & $20 \cdot 9$ & - & 14 & $1 \cdot 49$ & - & 917 & $2 \cdot 0$ & $38 \cdot 7$ \\
\hline
\end{tabular}

TABLE 66: L16 (a and b).

\begin{tabular}{|c|c|c|c|c|c|c|c|c|c|c|c|c|c|}
\hline 12 & $19 \cdot 5$ & $79 \cdot 0$ & 0.011 & - & - & - & - & - & - & - & - & - & \\
\hline 26 & $19 \cdot 8$ & $88 \cdot 5$ & 0.011 & 0.3 & $9 \cdot 5$ & $51 \cdot 7$ & $5 \cdot 4$ & 14 & $3 \cdot 69$ & $12 \cdot 0$ & 52 & $0 \cdot 3$ & $9 \cdot 5$ \\
\hline e 9 & $20 \cdot 5$ & $99 \cdot 3$ & 0.011 & $0 \cdot 7$ & $10 \cdot 8$ & $84 \cdot 4$ & $7 \cdot 8$ & 14 & 6.03 & $12 \cdot 3$ & 136 & 1.0 & $20 \cdot 3$ \\
\hline 23 & $20 \cdot 7$ & $102 \cdot 8$ & 0.011 & $0 \cdot 2$ & $3 \cdot 5$ & $73 \cdot 4$ & $21 \cdot 0$ & 14 & $5 \cdot 24$ & $3 \cdot 5$ & 209 & $1 \cdot 2$ & $23 \cdot 8$ \\
\hline & & & & & & & & & & & & & \\
\hline 7 & $20 \cdot 8$ & $104 \cdot 9$ & 0.012 & - & - & - & - & - & - & - & - & - & \\
\hline 21 & $21 \cdot 5$ & $114 \cdot 7$ & 0.012 & 0.7 & $9 \cdot 8$ & $72 \cdot 2$ & $7 \cdot 4$ & 14 & $5 \cdot 14$ & $9 \cdot 3$ & 72 & 0.7 & \\
\hline 4 & $22 \cdot 0$ & $126 \cdot 4$ & $0 \cdot 012$ & 0.5 & $11 \cdot 7$ & $82 \cdot 2$ & $7 \cdot 0$ & 14 & $5 \cdot 87$ & $10 \cdot 2$ & 154 & $1 \cdot 2$. & $21 \cdot 5$ \\
\hline 18 & $22 \cdot 5$ & $136 \cdot 7$ & $0 \cdot 012$ & 0.5 & $10 \cdot 3$ & $90 \cdot 4$ & $8 \cdot 8$ & 14 & $6 \cdot 46$ & $8 \cdot 1$ & 245 & $1 \cdot 7$ & 31.8 \\
\hline . 1 & $22 \cdot 9$ & $142 \cdot 3$ & 0.012 & 0.4 & $5 \cdot 6$ & $89 \cdot 0$ & $15 \cdot 9$ & 14 & $6 \cdot 36$ & $4 \cdot 1$ & 334 & $2 \cdot 1$ & $37 \cdot 4$ \\
\hline 15 & $23 \cdot 1$ & $153 \cdot 5$ & 0.012 & $0 \cdot 2$ & $11 \cdot 2$ & $85 \cdot 4$ & $7 \cdot 6$ & 14 & $6 \cdot 10$ & $7 \cdot 9$ & 420 & $2 \cdot 3$ & $48 \cdot 6$ \\
\hline 29 & $23 \cdot 6$ & $158 \cdot 7$ & 0.012 & 0.5 & $5 \cdot 2$ & $76 \cdot 4$ & $14 \cdot 7$ & 14 & $5 \cdot 46$ & $3 \cdot 4$ & 496 & $2 \cdot 8$ & $53 \cdot 8$ \\
\hline 13 & $24 \cdot 0$ & $177 \cdot 7$ & $0 \cdot 013$ & 0.4 & $19 \cdot 0$ & $121 \cdot 5$ & $6 \cdot 4$ & 14 & $8 \cdot 68$ & $12 \cdot 0$ & 618 & $3 \cdot 2$ & $2 \cdot 8$ \\
\hline 27 & $24 \cdot 3$ & $187 \cdot 0$ & 0.013 & $0 \cdot 3$ & $9 \cdot 3$ & $106 \cdot 2$ & $11 \cdot 4$ & 14 & $7 \cdot 59$ & $5 \cdot 2$ & 724 & $3 \cdot 5$ & $82 \cdot 1$ \\
\hline 10 & $24 \cdot 5$ & $192 \cdot 8$ & $0 \cdot 013$ & $0 \cdot 2$ & $5 \cdot 8$ & $98 \cdot 2$ & $16 \cdot 9$ & 14 & $7 \cdot 01$ & $3 \cdot 1$ & 822 & $3 \cdot 7$ & $87 \cdot 9$ \\
\hline 24 & $24 \cdot 6$ & $201 \cdot 8$ & 0.014 & $0 \cdot 1$ & $9 \cdot 0$ & $67 \cdot 5$ & $7 \cdot 5$ & 14 & $4 \cdot 82$ & $4 \cdot 6$ & 890 & $3 \cdot 8$ & $96 \cdot 4$ \\
\hline
\end{tabular}


